\title{
Interactive comment on "Devonian-Mississippian collapse and core complex exhumation, and partial decoupling and partitioning of Eurekan deformation as alternatives to the Ellesmerian Orogeny in Spitsbergen" by Jean-Baptiste P. Koehl
}

Jean-Baptiste Koehl

jean-baptiste.koehl@uit.no

Received and published: 4 June 2020

Dear Dr. Piepjohn, thank you very much for responding to my invitation to submit additional comments to my manuscript. Your input on the manuscript is highly appreciated. Thank you very much for taking the time to send your comments. Here is my reply to your comments. I hope that the changes implemented improve the shortcomings of the manuscript highlighted by your comments and suggestions. Please do not hesitate 
to contact me shall this not be the case for some comments. Please note the figures of this discussion were attached as supplements. Please do not hesitate to contact me should you require high-quality versions of the figures.

Introduction The concept of Ellesmerian/Svalbardian deformation event was first mentioned by Vogt (1938) to explain moderately-steeply dipping Devonian sedimentary beds below flat-lying uppermost Carboniferous-lowermost Permian strata of the Wordiekammen Formation in Dickson Land. This concept was brought up to fill a need, i.e., the need to explain the tilted and folded character of Devonian sedimentary rocks of the Andrée Land Group and Mimerdalen Subgroup below presumably undeformed uppermost Devonian-Mississippian strata of the Billefjorden Group and uppermost Carboniferous-lowermost Permian strata of the Wordiekammen Formation. The present manuscript shows that strata of the Billefjorden Group and Wordiekammen Formation are indeed deformed in places and uncovers structures localized at important lithological (rheological) boundaries, which may have partly/locally decoupled and partitioned Eurekan deformation. The newly evidenced structures, among which Eurekan bedding-parallel décollements, thrusts and duplexes, show that deformation patterns and differences between Devonian rocks of the Andrée Land Group and Mimerdalen Subgroup and overlying uppermost Devonian-Mississippian Billefjorden Group and uppermost Carboniferous-lowermost Permian Wordiekammen Formation can be simply explained by local strain partitioning and decoupling during Eurekan deformation possibly in association with Devonian extensional collapse (e.g., detachment folding, core complex exhumation), thus not requiring an extra phase of contractional/transpressional deformation in the Late Devonian. Although Dr. Piepjohn's studies also present abundant structural measurements made on actual outcrops at the bottom of valleys and along riverbeds, his regional models (e.g., Piepjohn et al., 1997a; Piepjohn, 2000) build on regional structural relationships, which are based on observations and interpretations made from great distance and on regional outcrop transects partly-mostly covered by screes and partly inaccessible (see Figure 2-Figure 25). Dr. Piepjohn's studies are, therefore, inappropriate to discuss local geological

Interactive comment
Printer-friendly version

Discussion paper 
processes and mechanisms such as the presence of local bedding-parallel duplexes and décollements (e.g., between the Wordiekammen Formation and Wood Bay Formation/Mimerdalen Subgroup and between the Billefjorden Group and the Wood Bay Formation/Mimerdalen Subgroup) that may affect sedimentary successions in central Spitsbergen and that are the object of the present manuscript (see Figure 1 for locations). The author of the present manuscript does not attempt to undermine the value The main issue raised by the present manuscript targets the episode of shallow-crustal to near-surface contraction/transpression inferred by Vogt (1938) and further discussed by Dr. Piepjohn and others (e.g., Dallmann, 1992; Piepjohn et a., 1997a; Kempe et al., 1997; Michaelsen, 1998; Piepjohn, 2000; Bergh et al., 2011; Dallmann and Piepjohn, submitted) in Dickson Land, Andrée Land, Blomstrandhalvøya, and southern Spitsbergen. It is long known that field observations are not necessarily reflecting the utlimate truth (Bardossy and Fodor, 2001). The present manuscript shows that evidences in favor of shallow-crustal to near-surface Ellesmerian/Svalbardian deformation in Devonian sedimentary rocks in Spitsbergen involve high amounts of uncertainty related to (1) over-interpretation of poorly exposed (because partly-mostly covered by screes) and mostly inaccessible (because of the steep slopes) regional outcrop transects (e.g., in Piepjohn et al., 1997a; Piepjohn, 2000), (2) erroneous field interpretation of lowangle extensional detachments, and/or tilted stratigraphic unconformities, and/or Eurekan thrusts as Ellesmerian thrusts (e.g., in Michaelsen, 1998), (3) poorly preserved spore assemblages (Buggisch et al., 1994) and erroneous palynological interpretation (Schweitzer, 1999; Piepjohn et al., 2000), and (4) omission/non-discussion of alternative hypotheses such as that of extensional detachment folding as discussed in Chorowicz (1992), Roy $(2007,2009)$ and Roy et al. (unpublished). The present discussion includes actual field photographs of regional transects in central Spitsbergen documenting the very low quality of regional outcrop transects in this area and the high amount of uncertainty associated to the interpretation of supporters of Ellesmerian/Svalbardian deformation (Figure 2-Figure 25). The photographs show that the field observations made by Dr. Piepjohn and his team are, at most, "permissive" to 
"suggestive" in the scale established by geoscientists and psychologists (Wilson et al., 2020) indicating "that a particular idea or interpretation [e.g., shallow Ellesmerian deformation in Svalbard] cannot be ruled out, but it is also not the only available solution" or "that there is positive evidence for a particular interpretation [e.g., shallow Ellesmerian deformation in Svalbard], but that the evidence also allows the possibility for other interpretation [e.g., continuous Devonian-Mississippian extensional collapse and Eurekan strain partitioning]". The present manuscript and present discussion emphasize the large amounts of uncertainty related to the method of acquisition of field observations in studies where field observations and regional structural relationships were established from great distance on partly-mostly covered (by screes) and inaccessible outcrop transects partly-mostly consisting of loose material (e.g., Piepjohn et al., 1997a; Piepjohn, 2000; Figure 2-Figure 25) by comparison with studies based on actual observations made looking at (and physically stepping onto) specific outcrops directly correlated to the structures discussed (present manuscript). It is well known that strain decoupling and partitioning may have a significant impact on the distribution of deformation and localization of structures in various lithostratigraphic units and throughout an area as shown, e.g., by recent studies by Janecke et al. (2018) and Bergh et al. (2019) along the San Andreas fault in California, but also in Spitsbergen where strong strain partitioning and decoupling is advocated during early Cenozoic contraction-transpression (e.g., Maher et al., 1997; Braathen et al., 1999a, 1999b; Bergh et al., 2000; Leever et al., 2011a, 2011b). In particular, Braathen et al. (1999a), who concluded that the West Spitsbergen Fold-and-Thrust Belt consists of "composite wedges" (referring to critical wedge taper), even wrote that this "translates into increased decoupling toward a weaker foreland" (central Spitsbergen is indeed relatively close to this foreland basin, the Central Tertiary Basin). Such decoupling is discussed further in the present study, but also in the studies of Koehl and Muñoz-Barrera (2018; presence of early Cenozoic bedding-parallel décollements within shales of the Billefjorden Group) and Koehl et al. (in prep. a; décollements parallel to stratigraphic boundaries, especially between Devonian rocks of the Andrée Land Group and Permian sed- 
imentary rocks of the Wordiekammen Formation). The revised version of the present manuscript also discusses the possible occurrence of deep, late Caledonian contraction tectonism in western Spitsbergen in the Late Devonian-Mississippian (Kosminska et al., 2017, 2020), which was comparable in intensity to late Caledonian deformation along the conjugate margin of Svalbard in northeastern Greenland (Gilotti et al., 2004; McClelland et al., 2006). In northeastern Greenland, Devonian-Mississippian eclogitefacies metamorphism was coeval with near-surface extensional collapse and deposition of thick Devonian-Mississippian sedimentary basins along low-angle extensional detachments (Stemmerik et al., 1991; Strachan, 1994; Larsen et al., 2008), which is common in phases of late-post-orogenic collapse (Platt, 1986; Rey et al., 2001). The author of the present manuscript is open to adding selected parts and/or figures of the discussion below to the submitted manuscript, should it be advised by the referees and/or editor.

Comments from Dr. Piepjohn Comment 1: General Comments: The manuscript "Devonian-Mississippian collapse and core complex exhumation, and partial decoupling and partitioning of Eurekan deformation as alternatives to the Ellesmerian Orogeny in Spitsbergen" presents a dramatic and revolutionary change in the hithero existing knowledge and interpretation of the structural evolution and geological development in the geological history of the archipelago of Svalbard. Comment 2: The argumentation and conclusion in this manuscript is based on (i) fieldwork in a small outcrop area in the vicinity of the Balliolbreen Fault near the Pyramiden Mine, (ii) on interpretation of a satellite image at the Groenhorgdalen/Triungen Fault Zone, (iii) on some seismic sections in the Tempelfjorden area and on publications (iv) on the Adriabukta Section (Hornsund) (Bergh et al. 2011) and (v) on a Devonian core complex in NWSpitsbergen (Braathen et al. 2017). Comment 3: Reading the manuscript, I have the impression, that the author hasn0t done any structural fieldwork except for the outcrop at the Pyramiden Mine. Except for this outcrop, all arguments are based on indirect observations (satellite image, seismic section) or on interpretations within the literature. Comment 4: For such a far-reaching hypothesis that the Ellesmerian Orogeny has 
not affected the Svalbard archipelago, the analysis of a single outcrop (with only 130 measurements!) is absolutely inadequate. Comment 5: The assumption, for example, that the base of the Billefjorden/Gipsdalen groups north of Isfjorden is a detachment instead of an unconformity, was not proven by the author, and the (Ellesmerian) structures directly west of the Balliolbreen Fault were not studied and compared with the Eurekan structures along the BFZ. Comment 6: In his manuscript, the author has also compared tectonic structures within the centre of the Devonian Andrée Land Basin in Andrée Land, but it is not obvious in the text, that he has really seen and worked on the structures in Andrée Land. Comment 7: However, that question, if the Ellesmerian deformation has affected Svalbard or not, is too important to be solved by the anaylsis of just one outcrop. For such a revolutionary idea, the presented data are too poor. Comment 8: The question if the Ellesmerian deformation has affected Svalbard or not would really be of scientific significance and would represent a substantial contribution to scientific progress concerning the tectonic evolution of the Arctic. However, as stated above, the conclusions that the Ellesmerian Orogeny is not present on Svalbard, and that the structures earlier described as Ellesmerian structures, can be explained by the results of a Devonian core complex and a de-coupling and partitioning of the Eurekan deformation are based on very poor structural outcrop results restricted to an extremely small area. The scientific approach and applied methods are not very valid. Comment 9: Apart from the field observations from the outcrop area at the Pyramiden Mine, the manuscript is full of assumptions, and most of the interpretation is not based on hard geological and structural field data. Comment 10: Hence, the results are often not discussed in an appropriate and balanced way. In many aspects, the selection of published work and references is one-sided, so that related work and many publications are not considered. Comment 11: The manuscript is too long, and many descriptions, argumentations and conclusions can be condensed. Comment 12: I am very impressed by the number of references and the work on the literature research. Comment 13: The quality of the figures can be improved: most of the figures are much too small, and it is difficult to recognize the structures, names and symbols mentioned 
in the text. Comment 14: It does not happen very often, that an entire fold-and-thrust belt and an entire orogeny are suggested to be abolished and disappear, and being replaced by a (possible) combination of (a) the formation of core complexes all over Spitsbergen and (b) the extent and enlargement of the Paleogene Eurekan deformation across entire NW-Spitsbergen towards the areas which were interpreted as part of the Ellesmerian Orogeny before. Comment 15: However, although the Ellesmerian (Svalbardian) Fold-and-Thrust Belt on Svalbard was object of many controversial discussions in the literature especially concerning the kinematics and its timing, the geoscientific community from the first observations in the beginning of the 20th century until now has generally agreed that the Svalbardian deformation event has taken place without a doubt. Comment 16: I am not against new ideas and open to new interpretations, however, the consequences presented in Koehls' manuscript are eminent to such an extent, that this ideas and the resultant change of the well-established geological history proved by thousands of hours of mapping and structural observations in the field with countless samples and measurements by so many geologists within the last hundred years across entire Svalbard in the field should be very carefully formulated and should be, of course, based on really extensive, well-documented and significant new field data. Comment 17: If the argumentation of the author is only based on field observations restricted to a small outcrop at Pyramiden near the Balliolbreen Fault, he should be really careful to suggest an overall, regional detachment across northern Spitsbergen. Comment 18: The argumentation within the present manuscript is mainly based on four or five columns: a) The timing of the Ellesmerian deformation on Svalbard b) Structural implications (detachment at the base of the Billefjorden Group) c) The assumption of core complexes on Svalbard d) Field observations, aerophotographs and seismic sections. Comment 19: Below, I would like to focus on the items listed above: (a) The timing of the possible Ellesmerian/Svalbardian deformation on Svalbard: The author is talking about the Devonian to Mississippian sedimentary succession overlying Early to Middle Devonian sedimentary units throughout the manuscript. But the author should mention that there are different opinions and that the age of the Billefjor- 
den Group is still a matter of debate: Our group and other geologists have suggested that the onset of sedimentation of the Billefjorden Group started in Viséan times and that the age of the uppermost Mimerdalen Group is Famennian (which is very similar to the Okse Bay Formation on Ellesmere Island (Beauchamp et al. 2018)). This is in contrast to Berry, Marshall and colleagues who suggested an older age for the Plantekloefta Formation and a Fammenian age for the base of the Billefjorden Group. This different opinions and interpretations on the ages of the sedimentary units (and therefore the Ellesmerian deformation) should be discussed in the manuscript. The author is, of course, free to use one of the two opinions, but he should mention, why he is choosing one of the two opinions. It is not a good scientific way to ignore other opinions. Comment 20: Therefore, it would be probably much better to use the neutral names of the stratigraphic units (Billefjorden/Gipsdalen groups overlying the Andrée Land Group/Mimerdalen Subgroup) instead of using confusing time segments (e.g., Devonian - Mississippian, Upper Devonian - Mississippian, Mississippian to Pensylvanian). Comment 21: Apart from the ages of the sedimentary units, the author should use the existing stratigraphic division of the upper part of the Devonian Old Red Sandstone: the Mimerdalen Subgroup and subordinary formations and members, which is not mentioned by the author, was accepted by the Norwegian Stratigraphic Committee und should be considered. Comment 22: However, the exact timing of the Ellesmerian deformation (Late Devonian (Frasnian?) or Tournaisian) is not important for the question, if the Ellesmerian deformation exists on Svalbard or not. Both time frames are possible for the Ellesmerian (Svalbardian) deformation on Svalbard, North-Greenland and the Canadian Arctic. Comment 23: (b) Structural implications (detachment at the base of the Billefjorden Group): For the conclusion in the presented manuscript that the Ellesmerian deformation does not exist on Svalbard, the nature of the contact between folded/thrust-faulted Andrée Land Group/Mimerdalen Subgroup and overlying mostly horizontal Billefjorden and Gipshuken groups is extremely important. The central interpretation in the manuscript is the statement, that this contact is poorly constrained (unconformity or detachment) in the Mimerdalen area (Fig. 1) and between Dickson

Interactive comment
Printer-friendly version

Discussion paper 
Land and Oscar II Land (Fig. 2). This may be correct for the small described outcrop at the Balliolbreen Fault near the entrance of the Pyramiden coal mine. But I don0t know, if the author has paid attention to or has seen and investigated this contact in the areas in central Dickson Land west of the Balliolbreen Fault (Fig. 1), in James I Land and further west towards the West Spitsbergen Fold-and-Thrust Belt (Fig. 2). It makes the impression, that the author is convinced that the contact of the Billefjorden/Gipsdalen groups on top of the ORS is poorly constrained everywhere. This indicates that it would be possible that the entire base of the Billefjorden/Gipsdalen groups between the BFZ and the WSFTB in the west might be a huge, regional detachment (Fig. 2). As this question is extremely important for the interpretation that the Ellesmerian deformation is not present in Svalbard, this fact should be more supported in the manuscript, either by own structural data and field analyses in those areas or by existing geological maps and publications. Comment 24: It is clear and well-known from seismic data, mapping and detailed structural fieldwork from a number of authors and publications that detachments exist in the Carboniferous/Permian evaporates and Triassic and Jurassic shales underneath the Central Tertiary Basin that transfer the deformation from the WSFTB ENE-wards to the BFZ and the LFZ. However, a large-scale detachment at the base of the post-Devonian sedimentary succession (base of Billefjorden/Gipsdalen groups) is nowhere indicated, described, shown or published in any existing geological map or stratigraphic, sedimentological or structural publication between BFZ in the east and the WSFTB in the west: this base is shown and described almost everywhere as a sedimentary contact and unconformity. Comment 25: The author has argued that the folds, reverse faults and thrusts described as Ellesmerian structures between the BFZ and the west coast of NW-Spitsbergen before, can be explained by de-coupling during the Eurekan deformation. Again: we are absolutely not against Eurekan structures in the vicinity of the BFZ or Lomfjorden Fault Zone (see Piepjohn et al. 2019) and reactivations of older structures during the Cenozoic deformation: such structures exist and have been earlier described by a number of authors. But the author should really compare the small-scale tectonic structures he has described in the manuscript in one

Printer-friendly version

Discussion paper
Interactive comment

\section{Discussion paper}

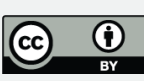


single outcrop at Pyramiden with the kilometer-scale fold structures and thrusts in Dickson Land (Fig. 1) and in Andrée Land and in the Liefdefjorden area. It is a characteristic of the Ellesmerian/Svalbardian deformation, that all structures (except for Soerkapp Land - and this question is still unsolved) are characterized by tectonic transports to the west (Fig. 2), indicated by west-vergent folds, west-directed thrusts and by a formation of an intense fracture cleavage. This direction is perpendicular to the general ENE-directed transports (fold structures, thrusts, fracture cleavage) of the Eurekan deformation (Fig. 2). Comment 26: In the Kongsforden area, the Eurekan structures turn into a NW-SE direction (Nedirected transports) forming a big angle with respect to the N-S trending, W-directed Ellesmerian structures (Fig. 2). This is not explained in the manuscript. Comment 27: From our point of view, and after observations of both orogenies along the entire west coast of Spitsbergen and in entire NW-Spitsbergen, there is a big difference in the architecture of the Ellesmerian and Eurekan structures. Comment 28: And the relative age control is proven in the Mimerdalen area in central Dickson Land by the Billefjorden Group unconformably overlying large-scale folds and thrust faults. Comment 29: If the assumption of a regional detachment underneath the Billefjorden/Gipsdalen groups should be correct, some questions appear: the dimensions of the fold-and-thrust zones in the Devonian (and also pre- Devonian rocks at the west coast of Spitsbergen north of Kongsfjorden) are quite big, and they are often characterized by out-of-sequence thrusts. How should it be possible that, if all the deformation is Eurekan, a sub-Billefjorden Group detachment was developed carrying the entire post-Devonian sedimentary succession westwards and cutting through all the fold-and-thrust zones (Fig. 3)? Comment 30: The author argues that, e.g., the Balliolbreen Fault and the lower Munindalen Thrust are not truncated by the postEllesmerian unconformity using this as an argument for the absence of the Ellesmerian - but the author does not take into account that there is a kilometer-scale Dicksonland Fold-and-Thrust Belt which is overlain by Billefjorden Group in central Dickson Land (Fig. 1). Comment 31: (c) The question of the core complexes: The author refers to a publication by Braathen et al. (2017) who suggested the existence of a large- 
scale, long-lived crustal detachment throughout Devonian times in the northwest part of Spitsbergen. From our knowledge of this area based on structural works during my own PhD-thesis and detailed mapping together with the NPI-colleagues over at least 6 or 7 field seasons, the existence of such a crustal detachment or core complex is improbable: (a) the geological situation is much more complex, (b) the documentation and description of the presented data is not convincing, (c) the age determinations are partly from areas $30 \mathrm{~km}$ away or are wrongly located, (d) the existence of structures (folds, thrusts, cleavage) of the E-W contraction of the Ellesmerian deformation is not even mentioned, (e) the mapped sedimentary contacts of the Devonian on top of the brecciated, weathered and karstified basement marbles is ignored, and ( $f$ ) the relation of ductile shear zones within the pre-Devonian basement rocks to the structures within the overlying Devonian rocks is not really taken into account. Comment 32: However, even if the existence of such a core complex would be correct, the author refers to this core complex assuming that a lot of other locations along faults like the Pretender Fault or faults in Soerkapp Land represent Devonian core complexes as well and that those assumed core complexes, instead of the Ellesmerian deformation - are typical and characteristic for entire Spitsbergen - again without checking and comparing this in the field at all questionable locations! Comment 33: There is also the contradiction between the assumed northward transport of the Devonian on top of the core complex, and the observed structures in the Devonian (folds, thrusts, cleavage formation) which prove an overall E-W contraction in this area. In my eyes, this is very dangerous! In the Devonian, there is no evidence for north-directed movements. Especially concerning such an important question if an entire Orogeny is present on Svalbard or not! Comment 34: Concerning the question of the assumed core complex in NW-Spitsbergen. It would be a good practice in science not only to refer to Braathen et al. (2017) but also to the field data and mapping results of previous work. The observations and interpretations of the "pro-Ellesmerian" people and the "pro-core complex" people are conflicting and disputed to such an extent, that the question of Ellesmerian structures versus core-complex structures should be discussed in the present paper. Comment 35: For 
this purpose and the conclusions in the present manuscript, the scientific differences are too big, and the author should take a form stand why he prefers the core-complex interpretation. However, Braathen et al. (2017) also haven0t discussed this elementary question in their paper also. Comment 36: As an example: from line 1175, the author writes that "A possible trigger for the steep eastward dip of Devonian (-Mississippian?) sedimentary strata of the Mariekammen and Adriabutka formations (after restoration) in Adriabukta (Fig. 1; Fig 5) MAY BE a core complex exhumation of Neoproterozoic basement rocks in the west (Fig. 7a-d), AS OBSERVED in central (Koehl, 2019; Koehl et al., in prep) and northwestern Spitsbergen". This is unbelievable: How can the author conclude the existence of a Devonian core complex just because the Devonian rocks are tilted? And this conclusion is only based on Bergh et al. (2011) from NWSpitsbergen and on the authors assumption from central Spitsbergen? Without any fieldwork and structural observation? However, there is a very easy explanation for the tilted Devonian rocks in the Adriabukta based on mapping and 3 days of structural fieldwork along the Adriabukta section: the Devonian rocks were folded (F1 and F2 in the Adriabukta Fm) and thrust-faulted including the formation of e distinct fracture cleavage before the deposition of the Billefjorden Group: the Ellesmerian deformation! This scenario is much easier to explain than the existence of an assumed core complex. If there is a core complex: please give me evidence!!! Comment 37: (d) Field observations, aerophotographs and seismic sections: Many interpretations in the presented manuscript are based on structural fieldwork within a very small outcrop area at the Balliolbreen Fault near the entrance of the Pyramiden Mine (Koehls' Fig. 2, 3a, 3b). That is great, because no geologists have paid attention to this outcrop before. And I completely agree that many structures in this outcrop represent Eurekan structures, especially in the sedimentary rocks of the Billefjorden Group and younger stratigraphic units, but also partly in the Early Devonian Wood Bay Formation to the west of the Balliolbreen Fault. On the other hand: some structural observations restricted to a single small outcrop (with a total of just 130 measurements!!) are not enough to really present serious arguments for a fundamental change in the geological history of 
Spitsbergen and in the elimination of an entire Orogen. Comment 38: The second outcrop presented and described in the manuscript is reduced to a satellite image of the Triungen-Grønhorgdalen Fault Zone west of Triungen (Koehls' Fig. 3c). Disregarding that nothing is really visible on the images, not a single field observation has been done in the Triungen area, and no real field data are described or presented in the manuscript. Regardless, the author uses the very poor to nonexistent evidence from the satellite images to support his assumptions. Comment 39: The third outcrop area is located along the Adriabukta profile in inner Hornsund. Again, I have the feeling that author has not visited this outcrop, because own field data and measurements are not described in the manuscript. Comment 40: And the author again does not take into account that previous detailed work has been done along the Adriabukta outcrop, e.g., von Gosen and Piepjohn (2001), who have presented different ideas. His interpretation is therefore only based on some selected publications, e.g., Bergh et al. (2011) - this avoids discussion and dispute on the very difficult geology at Adriabukta. However, the author concludes again, that the Ellesmerian deformation was not present in southern Spitsbergen but a Devonian core complex has developed instead. Comment 41: This is really a dangerous conclusion (similar to the authors statement on the Pretender Fault): the author does not present serious arguments, field data and observations, but assumes all the time in several locations from very poor considerations that the Devonian/Carboniferous history of entire Svalbard is dominated by the absence of the Ellesmerian deformation and the presence of Devonian core complexes. Very fast assumptions turn into "truth" in this manuscript! Comment 42: The author uses and presents seismic sections from Tempelfjorden and Reinsdalspasset (by the way: it is a lot of work to look for and to identify the locations of the seismic sections on Figure $1 \mathrm{a}, \mathrm{b})$. In my eyes, most of the seismic sections presented in the manuscript, are over-interpreted. The question, for example, if Devonian deposits are present east of the Billefjorden Fault Zone in eastern Nordenskiöld Land, cannot be really answered. As I know from colleagues working on the interpretation of seismic sections at BGR, it is always difficult to interpret the stratigraphy in seismic sections if there are no drill 
holes or outcrops near the section. Comment 43: In the presented manuscript, the interpretation is careful (the existence of Devonian sediments east of the BFZ might be possible), but later in the interpretation, this weak argument becomes important and almost fact to argue against the Ellesmerian deformation. It would be better to be a little bit more careful using the seismic sections really as arguments. Comment 44: In addition: the presented seismic sections in the figure are unfortunately not really readable: what is described in the text, cannot really be recognized in the figures. Comment 45: If it is correct that the Ellesmerian deformation has not affected the Devonian ORS sandstone and underlying basement rocks, another question appears: before the Late Devonian, the geological history of Svalbard (and the Pearya Terrane) on the one hand and North Greenland and the Canadian Arctic on the other hand was completely different. Already some million years later, Spitsbergen was located somewhere north of northern Greenland at least since Early Carboniferous times. This is proven by the similarity of the post-Devonian sedimentary successions in the sedimentary basin on Svalbard, the Wandel Sea Basin in northern Greenland, and the Sverdrup Basin in the Canadian Arctic. Just before, the northern margin of Greenland and the Canadian Arctic were affected by the formation of the $100-350 \mathrm{~km}$ wide Ellesmerian Foldand-Thrust Belt. What happened in between? There must have been an approach and collision of Svalbard/Pearya with the northern margin of Laurentian - which is the Ellesmerian Orogeny. How does the author explains the absence of Ellesmerian structures on Svalbard, when Ellesmerian structures exist to the same time not very far away to the south? Comment 46: Figures: I like the figure captions very much. They are describing the situation on the figure well and are very detailed. Comment 47: Figure 1: The overview map of Svalbard is ok. But the arrows and localities (Re, $\mathrm{Kg}, \mathrm{Rs}$ etc.) are too small and only readable with magnifying glasses. The geological map Fig. $1 \mathrm{~b}$ is too small and very difficult to read. Comment 48: Figure 2: Nice picture - it is a little bit dark. The geological symbols can be bigger and the lines thicker. The lines are difficult to distinguish. And there is enough space for a legend: I don0t like always to go from the figure into the figure caption to get the information for a symbol or line - put it in 
a legend! Comment 49: Figure 3a: same as Figure 2. There is space enough to enlarge the text and symbols in the figure. Figure $3 b$ should be enlarged. It shows some important features which are explained in the text. And again: put the explanation for the lines in a legend on Figure 3b. Comment 50: Figure 3c: this figure is useless and shows nothing which is important for the conclusions in the manuscript. Comment 51 : Figure 4: With magnifying glasses, I can see a little bit on Fig. 4a-g, but most of the structures described in the manuscript are invisible on the seismic sections. May be, a higher contrast would be helpful. In any case, the seismic sections should be enlarged and distributed in several figures. Comment 52: Figure 5: It would be very nice, if the documentation in this manuscript would be a bit better: where is the profile in Fig. $5 \mathrm{a}$ located? The legend shows that the Adriabukta Fm is Upper Devonian to Mississippian in age. Does it mean that this unit belongs to the Billefjorden Group? Comment 53: In the legend, a Mississippian age is indicated for the Hornsundneset Fm - in the stratigraphic lexicon (Dallmann 1999) the age is indicated as Viséan. By the way: the Hornsundneset Fm is not even indicated in the cross section! This is quite confusing for the reader! Comment 54: In the restored profile Fig. 5b, the restored Adriabukta Fm underneath the Hyrnefjellet Fm is 5-6 km thick? And unlimited to the east? And the Mariekammen Shear Zone is a normal fault now? We have interpreted the Mariekammen Shear Zone as a dextral strike-slip fault, Bergh et al. (2011) follows that it is a sinistral fault. Comment 55: Figure 6: This succession of cross sections through time does not show the geological situation exposed in Dickson Land and Bünsow Land across the BFZ: - First of all, the existence of Devonian deposits (Andrée Land Group) east of the BFZ is not proven and is only based on the authors interpretation of the seismic section Fig. 4g. - The Devonian ORS-deposits west of the Balliolbreen Fault are extremely thin near the fault and thicken towards the west. There is no evidence for this assumption. One should also take into account that the base of the ORSsandstone west of the Balliolbreen Fault is absolutely unknown. Neither the depth of the basement is know nor the nature of the basement. Comment 56: Fig. 3d shows the situation during Cenozoic thrusting with an anticline including the basement, the 
Devonian and younger deposits west of the Balliolbreen Fault. Such bending with an eastward dip of the eastern limb of the assumed anticline would suggest downfaulting of the eastern block along the Balliolbreen Fault but not west-directed reverse faulting. And my major question is: where are the kilometer-scale folds and thrusts of the Dickson Land fold-and-thrust zone (compare attached Fig. 3)? Comment 57: Fig. 6e: there is absolutely nothing to recognize because the little diagrams are much too small. In the figure caption it is written that these parts of the cross section : : : fit into the field observations in key localities discussed in the text. I have not seen that, except for the outcrop at Pyramiden, any of the other outcrops was presented with new and own field observations and field data. And all observations do not argue against the Ellesmerian deformation! Comment 58: Figure 7: This is a very oversimplified sketch as well. Is there any field evidence for the existence of a metamorphic core complex? Going to the area south of Hornsund, Adriabukta Fm is unconformably overlying crystalline basement rocks east of the main Devonian exposures. This is not taken into account in the presented cross sections. Comment 59: I also cannot see the Hornsundneset $\mathrm{Fm}$ in the cross section in Fig. 5a. Comment 60: Literature: I am quite impressed how many publications are cited in the manuscript. However, there are some citations in the text which do not appear in the reference list, and vice versa. I have attached a list of missing references below. Literature check: Baelum \& Braathen 2012 - missing in the reference list! Dallmann \& Maher 1989 - missing in the reference list! Frodsham \& Gayer 1999 - missing in the reference list! Gawthorpe \& Leeder 2003 - missing in the reference list! Haremo et al. 1990 - missing in the reference list! Koehl et al. in preparation - missing in the reference list! Lamar \& Douglass 1995 - missing in the reference list! Piepjohn \& von Gosen 2017 - missing in the reference list! Prosser 2013 - missing in the reference list! Roy 2007 - ok - not free availabe Roy 2009 - ok - not free availabe Roy et al. unpublished - that is not really a reference!!! Schlische 1995 - missing in the reference list! Steel \& Worsley 1984 - cited in the reference list but missing in the text!! Thomas 2002 - cited in the reference list but missing in the text!! Welbon et al. 1992 - missing in the reference list! Wilson \& Wojtal 1986 - missing in 
the reference list! Worsley \& Mörk 1978 - missing in the reference list! Comment 61:

Fig. 1. Fig. 1: Geological Map of central Dickson Land showing the intense deformation Discussion paper within the (Ellemserian) Dickson Land Fold-and-Thrust Zone underneath the mostly horizontal Carboniferous and younger str Comment 62:

Fig. 2. Fig. 2: Except for Soerkapp Land, the Ellesmerian transport directions are west-directed - in contrast to the ENE-transport within the West Spitsbergen Fold-andThrust Belt. There are exceptions in Eu Comment 63:

Fig. 3. Fig. 3: Interpretation of an Ellesmerian fold-and-thrust zone unconformably overlain by Carboniferous and younger deposits of the Billefjorden and Dipsdalen groups (above). In case of a Eurekan struct Comment 64: line 14: "In the Late Devonian", or earliest Carboniferous. Comment 65: line 17: "and juxtaposition of undeformed Mississippian-Permian strata against intensely folded Devonian rocks", that is not correct: the juxtaposition of the Mississippian-Permian strata is not part of the Svalbardian Orogeny - it is post-Billefjorden Group. Comment 66: line 28: "Wördiekammen", Wordiekammen. Comment 67: lines 34-35: "thus ruling out Late Devonian reverse movement along the Billefjorden Fault Zone in this area", Why does the existence of Devonian east of the BFZ rules out Svalbardian movements? Comment 68: line 37: "may be explained by down-east Carboniferous normal faulting", Devonian rocks and underlying basement are exposed west of the BFZ and basement rocks (and eroded Devonian) east of the BFZ. How can this be explained by Carboniferous normal faulting with downthrow to the east? In this case, the Devonian shold be exposed east and the basement west of the BFZ. Comment 69: lines 38-39: "top-west Cenozoic thrusting along the Billefjorden Fault Zone", I understand the argument that the Eurekan has re-activated the BFZ (Balliolbreen Fault) with top-to-the-west displacements - but the Eurekan movements along the Billefjorden Fault Zone are not very large. Comment 70: lines 40-42: "the poorly constrained nature of the contact (unconformity or bedding-parallel décollements and thrusts?) between Lower Devonian and uppermost Devonian-Mississippian sedimentary strata", The contact between the Andrée Land 
Group/Mimedalen Subgroup and the overlying Billefjorden/Gipsdalen groups is possibly poorly constrained in the little outcrop area at the mine at Pyramiden. But what is about the nature of this contact in central Dickson Land west of the BFZ, in James I Land and farther west towards WSFTB? Do you think that the contact between the two sedimentary units is also poorly contrained and is possibly a detachment? Comment 71: line 46: "due to strain partitioning", I do agree that Eurekan deformation has affected the area along BFZ and LFZ reactivating older structures. I doubt that the great differences in deformation along the BFZ on the one hand and in the fold-and-thrust zones in the ORS basin (and in the basement at the west coast of northern Spitsbergen) is related to strain partitioning. This would only be correct if the base of the Billefjorden/Gipsdalen groups between BFZ and the WSFBT is be a detachment. In addition, you should have also have investigated the kilometer-scale structures in the Devonian west of the Balliolbreen Fault in central Dickson Land to support the idea of partitioning. Othwerwise, it is an assumption. Comment 72: lines 46-47: "Devonian core complex exhumation and reinterpretation of presumed Ellesmerian structures", The paper on the Devonian core complex has not reinterpreted the Svalbardian structures in the Liefdefjorden are - Svalbardian structures are not even mentioned there. Comment 73: lines 48-49: "that Ellesmerian contraction is not necessary to explain fault geometries and (differential) deformation within Devonian-Permian sedimentary strata", This sentence is not correct: nobody has ever said that the Ellesmerian deformation has affected the Billefjorden and younger sedimentary rocks!!! The Ellesmerian deformation pre-dates the Billefjorden Group! Comment 74: line 53: "Svalbardian Orogeny", Is there any citation or reference on the definition of the Ellesmerian and Svalbardian orogeny? Comment 75: line 56: "Franklinian basement", there is no Franklinian BASEMENT!! You probably mean the Franklinian BASIN! Comment 76: line 56: "northerneastern", northeastern. Comment 77: line 56: "Russia", There is no Franklinian Basin, as defined by Thorsteinsson \& Tozer, in Russia. Comment 78: line 59: "van", von!!!!! Comment 79: line 59: "Alaska", There is no Franklinian Basin, as defined by Thorsteinsson \& Tozer, in Russia. And there is no Ellesmerian deformation,

Interactive comment

Printer-friendly version

Discussion paper

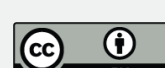


but the mid-Devonian Romanzof Orogeny. Comment 80: line 60: "Precambrian basement units", You mean the Neoproterozoic to Silurian Franklinian Basin? The basement is older and pre-Franklinian. Comment 81: line 60: "northeastern", northern. Comment 82: line 61: "Devonian collapse basins and Precambrian-early Paleozoic basement in Norway", these collapse basins are not part of the Ellesmerian deformation. Comment 83: line 62: "McCann, 2000; Piepjohn, 2000; Piepjohn et al., 2000", We have never said that the deformation of the ORS on Svalbard is related to Devonian collapse. Therefore, these references are wrong and must be removed here. Comment 84: line 63: "central", north. Comment 85: lines 65-66: "Piepjohn, 2000; Piepjohn et al., 2000", We were not the first geologiosts who have defined the Svalbardian deformation!!! The older references must be considered. Comment 86: line 72: "early Paleozoic Caledonian Orogeny", Please be careful, when you are talking about the Canadian Arctic and North Greenland: the structures in these areas are NOT related to the Caledonian Orogeny because the Caledonian Orogeny has not affected the northern margin of Laurentia (except for the Pearya Terrane which docked against Laurentia during the Ellesmerian). And on Svalbard, the fold-structures and thrusts in the Devonian ORS are younger than Caledonian. Comment 87: line 72: "Cenozoic Eurekan deformation", I agree - therefore we are very careful with the interpretation of the age of tectonic structures (either Ellesmerian or Eurekan) in the Canadian Arctic, North Greenland and Svalbard. Hovewer, the structural field data, the cutting relationships of structures, transport directions and the comparison of structures in the three areas make it mostly possible to identify Ellesmerian and/or Eurekan structures. Comment 88: line 82: "Piepjohn, 2000; Piepjohn et al., 2000; Rippington et al., 2010", There are more and older geologists who have suggested that the Ellesmerian and Svalbardian belong to the same foldbelt. Comment 89: line 82: "Rippington et al., 2010", I doubt hat Rippington et al. 2010 have ever visited the Pyramiden area in Spitsbergen. This citation is therefore not correct! Comment 90: lines 83-84: "Contractional structures in uppermost Devonian-Mississippian coal seams and shales of the Billefjorden Group", In case of contractional structures in the Billefjorden Group, 
this deformation should of course be Eurekan (as you say) and not Ellesmerian, because Ellesmerian pre-dates the Billefjorden Group. But this is not an argument for the absence of the Ellesmerian here. Comment 91: lines 93-94: "Balliolbreen Fault, a major segment of the east-dipping Billefjorden Fault Zone",in general, is there any citation on the scientists, who have desrcibed and named the faults first? Comment 92: line 95: "throughout Spitsbergen", how can you reinterpret Ellesmerian structures THROUGHOUT Spitsbergen, when you have just worked on a little outcrop in the Pyramiden area? Comment 93: line 96: "Figure 1a-b", that cannot be seen on Fig. 1. Comment 94: line 100: "Northeast Greenland", There is no Ellesmerian Deformation in NE-Greenland (Kronprins Christians Land and Trolle Land). The Ellesmerian foldbelt is located in North Greenland north of Independence Fjord. Comment 95: line 101: “, ", et al.. Comment 96: line 104: "northeastern", northern. Comment 97: line 104: "northern Alaska", It is not clear if the Ellesmerian Orogeny is represented in Alaska. There, the mid-Devonian Romanzof Orogeny is developed. The southwestern continuation of the Ellesmerian Orogeny towards Yukon is unclear. Comment 98: line 105: "northeastern Russia", It is also not clear, if the Ellesmerian Orogeny is represented in Northeast Russia. There may be a deformation at the same time on Wrangel Island, and there is papers which also suggest that the Ellesmerian Orogeny is present on the New Siberian Islands. However, we have not found evidence for a deformation and an important unconformity on the New Siberian Islands. Comment 99: line 119: "Caledonian contraction-transpression", Contraction-transpression during the Caledonian, Ellesmerian and Eurekan? Sometimes is it also only contractional. Comment 100: line 125: "125", Caledonides in central Spitsbergen? Where? Comment 101: line 125: "central and", Caledonides in central Spitsbergen? Where? Comment 102: line 126: "thrust stacks", Thrust stacks are not developed in the nortwestern province and on Nordaustlandet. Comment 103: line 140: "groups",Where are the citation of the colleagues who have established these stratigraphic units? Comment 104: line 141: "Bockfjorden", There is no halfgraben in Bockfjorden! Comment 105: line 142: "Andrée Land", There is also no halfgraben in Andrée Land. Who has published that there are 
halfgrabens in Andrée Land? Comment 106: line 142: "Kota", Where and was is Kota? Comment 107: lines 143-144: "deposited along low-angle, post-Caledonian detachments", Deposition and detachment-faulting to the same time? Comment 108: line 144: "of top-east", There are, indeed, some east-directed back-thrusts in the ORS in the Woodfjorden area. But in general, the transport directions within the Andrée Land Basin are towards the WNW to WSW. Comment 109: line 144-145: "(e.g., the Woodfjorden Detachment)", Where is the Woodfjorden detachment and what is it? I have no idea about this detachment and would be curious to read the publication about it. Roy et al. unpubl. is really not a reference! Comment 110: line 145: "syn-kinematic east-verging folds", Syn-kinematics folds? We have never seen E-vergent folds in the Andrée Land Basin, except in the vicinity of back thrusts. The only E-vergent folds in the ORS of Svalbard are located on Soerkapp Land. Comment 111: lines 145146: "(Roy, 2007, 2009; Roy et al., unpublished)", It is a pity that the Roy-papers are not available or are unpublished. Comment 112: Line 154: "Late Devonian (Mississippian?) Adriabukta Formation", Taking this age, this sedimentary unit should be equivalent of the Billefjorden Group. But it is also possible that it is an equivalent to the Mimerdalen Subgroup, (cited as pers. com .in Bergh et al. 2011; Piepjohn \& Dallmann and Dallmann \& Piepjohn (submitted). Comment 113: Line 159: "contraction", Contraction? Sometimes you say contraction-transpression? It's a little but confusing! Comment 114: Line 161: "Piepjohn et al., 2000",No, we didn't say that!!!!! We said that the Ellesmerian in Spitsbergen is most likely Tournaisian in age!!! Comment 115: Lines 161-162: "was presumably recorded by the deposition of coarse-grained sedimentary rocks of the Planteryggen and Plantekløfta formations", We (and other authors) have not said that the Ellesmerian deformation was recorded by the deposition of the Mimerdalen Subgroup, but that the deposition of the Mimerdalen Subgroup represented the onset of Svalbardian uplift in the east as a first stage. As you can see by the km-scale fold-structures in Mimerdalen, which are unconformably overlain by Carboniferous and younger rocks, the (Svalbardian) folding has affected the entire Mimerdalen Subgroup . Comment 116: Line 167: "Piepjohn, 2000", Please delete

Interactive comment
Printer-friendly version

Discussion paper 
this ciation. It gives the impression that Piepjohn (2000) has said that the Svalbardian is pre-middle Famennian in age. In contrast, our interpetation is that the Svalbardian is Tournaisian in age. Comment 117: Line 170: "more recent", Other studies. And there were more studies before. Comment 118: Line 174: “(Piepjohn, 2000; Bergh et al., 2011; Braathen et al., 2011)", It would be always great to refer to the people who were the first ones who have published that the Balliobreen Fault is a W-directed reverse fault carrying basement on top of Devonian!!!!!! Myself, Bergh and Braathen were not the first ones! Comment 119: Line 177: "Piepjohn, 2000", And I was not the first who said that the Billefjorden Group unconformably overlies folded Devonian deposits. Please use correct citations!!!!! Comment 120: Line 178: "lower Munindalen thrust", The lower Munindalen Thrust was firstly described by McCann (1993) and McCann \& Dallmann (1996) - please refer to them!! Comment 121: Line 179: "lower Frasnian", You should take into account that there are other age determinations by Brinkmann, Greving, Piepjohn and Dallmann suggesting a Famennian age of the Plantekloefta Formation. I know that Berry and colleagues don't like our age determinations and the fact, that a lot of material, fossils and spores in the Mimerdalen Subgroup have been reworked and redeposited (see Hugindalen Phase). You should discuss the different age determinations. Comment 122: Line 179: "Berry and Marshall, 2015; Newman et al., 2019", The Munindalen Thrust was named by McCann (1993) and McCann \& Dallmann (1996) (see above) and not by Berry \& Marschall and Newman et al.!!!! Comment 123: Line 181: "ö", o. Comment 124: Line 182: "I", i. Comment 125: Line 183: "Figure", That is really very difficult to see. Comment 126: Lines 183-184: "folded Lower Devonian rocks of the Wood Bay Formation are juxtaposed against flat-lying, undeformed, Carboniferous-Permian", That is quite interesting - but what do you want to say? And how and why is this juxtaposition related to the Ellesmerian? The juxtaposition is a post-Ellesmerian structure possibly related to the formation of the Billefjorden Trough or maybe even Eurekan movements. Comment 127: Line 185: "ö", o. Comment 128: Line 188: "is thought to be unconformably overlain by undeformed", You are refering to Odellfjellet and Sentinelfjellet - but why are you

Interactive comment
Printer-friendly version

Discussion paper

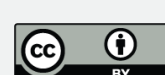


not refering to the Mimerdalen/Munindalen area, where the folded Devonian rocks ARE unconformably overlain by undeformed Mississippian rocks of the Billefjorden Group not "thought to be unconformably overlain..."! Comment 129: Line 193-194: "although timing remains speculative because most post-Devonian sedimentary rocks in the area were eroded", The comparison of the deformation in Andree Land and in Dickson Land indicate that they belong to the same deformation and not to two separate stages. As these structures are overlain by Carboniferous strata in Dickson Land, the probablilty that the structures in Andree Land are pre-Carboniferous as well - don't talk about speculation; you are speculating by yourself. Comment 130: Line 197: "Bergh et al., 2011", To my knowledge, Bergh et al. (2011) have not worked in Andrée Land!! And Bergh et al. (2011) and Dallmann \& Piepjohn (subm) are not the first ones who have described the folded Devonian in southern Spitsbergen! It is not OK that you never refer to the original papers but only to the papers that are just repeating the original papers!! That is not correct! Comment 131: Lines 197-199: "The main argument for Ellesmerian tectonism in southern Spitsbergen is the occurrence of a ca. 250-300 m-thick shear zone, the Mariekammen Shear Zone (Bergh et al., 2011)", First of all: the Mariekammen Shear Zone is NOT the main argument for the Ellesmerian in southern Spitsbergen but the folded Devonian redbeds unconformably overlain by Triassic strata south of Hornsund along Samarinbreen Secondly: There are some problems with the Mariekammen Shear Zone First of all: The paper by Braathen et al. (2011) do not really say if the Mariekammen Shear Zone is dextral or sinistral!!! Following von Gosen \& Piepjohn (2001), the Mariekammen Shear Zone is dextral. Comment 132: Line 200: "Upper Devonian-Mississippian, shaly sedimentary beds of the Adriabukta Formation", Today, the Adriabukta Formation is not beleaved to be Billefjorden Group anymore but possibly Middle to Late Devonian Mimerdalen Subgroup (Piepjohn \& Dallmann and Dallmann \& Piepjohn, submitted). You have already mentioned this and have cited Bergh et al. (2011). Comment 133: Lines 206-208: "Upwards, the Mariekammen Shear Zone is truncated by a moderately dipping erosional unconformity above which Pennsylvanian sedimentary rocks of the Hyrnefjellet Formation were 
deposited", We have not seen this outcrop situation during our fieldwork in 1992 (von Gosen \& Piepjohn 2001) - in this case, our interpretation of a Eurekan Mariekammen dextral strike-slip would be, of course, wrong, and the age of the Mariekammen Shear Zone would be pre-Pennsylvania, as Bergh et al. 2011 have suggested. Comment 134: Lines 221-222: "Austfjorden in the north to Reindalspasset",I can't see Austfjorden and Reinsdalpasset in Fig. 1. Comment 135: Line 235: "2019", The publication year is 2018. Comment 136: Line 240: “ö”, o. Comment 137: Lines 249-250: "was accompanied by kilometer scale displacement along N-S-striking faults", What kind of displacements? Strike-slip? If so, sinistral or dextral? I know that there are so many interpretations of structures and kinematics on Spitsbergen, but it would be really nice to see at least some structural evidence!! Comment 138: Line 251: "ö", o. Comment 139: Line 256: "ca. 62 Ma", The fieldwork on Spitsbergen, NE-Greenland, Ellesmere Island (Vendom Fiord Fault Zone, fault zones on Pearya, Wegener Fault) and Banks Island has shown that the majority of tectonic activities along the Eurekan fault zones post-dates $62 \mathrm{Ma}$ and was most likely active in Eocene times. Comment 140: Line 256: "Eurekan transpression", Is the transpression really the only way to explain the Eurekan on Spitsbergen? Comment 141: Lines 263-264: "(Harland and Horsfield, 1974; Bergh and Andresen, 1990; Dallmann et al., 1993b; Bergh et al., 2011; Blinova et al., 2012)",Where is the BGR-group (Tessensohn 2001)? Is the fieldwork, we have done along the WSFTB worthless to be taken into consideration? Comment 142: Line 265: "Bergh and Andresen, 1990", Why are you not refering to Harland, who has suggested that the bending of the structures on Broeggerhalvoeya from a general NNW-SSE trend to a WNW-ESE trend could be related to dextral transpression? Comment 143: Line 269: "Billefjorden Fault Zone", ...and the Lomfjorden Fault Zone: Piepjohn et al. 2019 and earlier workers. Comment 144: Line 269: "contraction", Contraction? It is a little bit confusing because you sometimes describe the Eurekan as being contractional, sometimes as contractional/tranpressional! What is correct? Comment 145: Line 291: "where erosion exposed", ?? Comment 146: Line 292: "Bergh et al., 2011", Bergh et al. (2011) are not the first geologists who have

Interactive comment
Printer-friendly version

Discussion paper

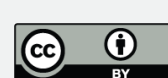


worked and described the Adriabukta Section. I guess the structure at Hyrnefjellet was already published by Dallmann, and there is a detailed description by von Gosen \& Piepjohn (2001). Comment 147: Lines 293-295: "the unconformity surface between the Hyrnefjellet and Adriabukta formations was restored to a horizontal geometry", See above: von Gosen \& Piepjohn (2001). Why is their description and interpretation not discussed in this paper? Comment 148: Lines 304-305: "In Pyramiden, a steeply east-dipping, $\mathrm{N}-\mathrm{S}$-striking brittle fault crops out in a gully below the entrance of the Russian coal mine (Error! Reference source not found.).", It is great, that the authors have worked on the Balliolbreen Fault at Pyramiden - this is new data, and nobody has done this before! Comment 149: Line 307: "east-verging folds with", I can't see an E-vergent fold in Fig. 2 and Fig. 3a with an overturned eastern (that should be steeply W-dipping) short limb. What is the indication for this E-vergence? Is there a cutting-relationship of bedding/cleavage, which confirms the E-vergence? The lower hemisphere diagram shows some steeply E-dipping bedding planes). Comment 150: Line 307: "overturned eastern limb", Again: where is the overturned eastern limb? Comment 151: Line 312: "There is no trace of Hecla Hoek basement in this area", I agree that there is probably no pre-Devonian basement exposed in southern slope of Pyramiden mountain north of the settlement. But further north, the Balliolbreen Fault clearly carries basement rocks on top of Devonian sediments. Please avoid the name "Hecla Hoek"!! That was used more than 20 years ago! Comment 152: Lines 315-318: "Sample preparation for thin sectioning actually proved problematic for Devonian sedimentary rocks located in the hanging wall of the presumed fault, which resulted in a misleading thick section (supplement 1).", I don't understand this sentence. Comment 153: Lines 318-319: "Devonian-Mississippian sedimentary rocks of the Wood Bay Formation", Devonian-Mississippian rocks of the Wood Bay Formation????? I think that is Billefjorden Group? Comment 154: Lines 321-323: "Farther up the gully, a onetwo meter-thick succession of interbedded sandstone and coal is juxtaposed against steeply east-dipping Devonian strata to the west and overlain by a (at least three meter) thick layer of uppermost Devonian-Mississippian coals of the Billefjorden Group",

Interactive comment
Printer-friendly version

Discussion paper

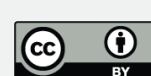


Is the 1 to $2 \mathrm{~m}$-thick succession of sandstone and coal (E of the Devonian strata) overlain by coals of the Billefjorden Group??? Are both described coals Billefjorden Group? I don't understand this sentence. Comment 155: Line 334: "Insey", Insay. Comment 156: Line 336: "underlying Devonian rocks", I still don't understand the geological situation: there is a 1 to $2 \mathrm{~m}$ thick sandstone and coal succession overlain by "uppermost Devonian"-Mississippian coals of the Billefjorden Group. If so, is the (lower) sandstone and coal succession part of the Devonian Wood Bay Formation? Except for the cannel coal in Mimerdalen, there is no coal seams at all in the Devonian to my knowledge. Comment 157: Lines 344-348: "The nomenclature of hindward/forward-dipping duplexes of Boyer and Elliott (1982) does not apply here since the foreland of the West Spitsbergen Fold-and-Thrust Belt (Tertiary Central Basin) is located southeast of Pyramiden. Thus, the term "backward" is used to describe the east-dipping character of the duplexes, i.e., opposite to the inferred transport direction.", I don't understand this statement - not necessary. Comment 158: Line 358: "do not appear to be faulted", Is there an unconformity across the contact? Comment 159: Lines 363-366: "Noteworthy, most outcrops of uppermost Devonian-Mississippian strata in this part of the study area trend E-W to WNW-ESE. Thus, the dominance of WNW-ESE-striking faults is unlikely the result of measurements flawed by a preferential outcrop trend, since EW- to WNW-ESE-trending outcrops would rather favor identification and measurement of N-S-striking faults.", Not necessary. Comment 160: Lines 377-386: "4.1.2 Triungen Satellite images in Triungen (Error! Reference source not found.a-b) show that the Triungen-Grønhorgdalen Fault Zone (McCann and Dallmann, 1996) and the contact between Lower Devonian of the Wood Bay Formation and overlying uppermost Devonian-Mississippian sedimentary rocks of the Billefjorden Group in the hanging wall are largely covered by dark screes (Fig. Error! Reference source not found.c). Based on the presence of thick, flat-lying, coal-rich strata in the lower part of the Billefjorden Group overlying Lower Devonian sedimentary strata in the hanging wall of the fault, the dark screes along the fault trace (right hand-side inset in Fig. Error! Reference source not found.c) are believed to represent uppermost Devonian-Mississippian 
coals-coaly shales that might have been dragged along the Triungen-Grønhorgdalen Fault Zone during tectonic movements.", Have you carried out fieldwork at Triungen? If not, please cancel this chapter - just showing a satellite image is really not enough data and not enough for a good scientific discussion and interpretation. There are other paople who have worked and mapped the area who should be cited: Greving and Dißmann. And at Triungen, the youngest spores in the coal near the base of the Billefjorden Group are Viséan in age - but that is probably not important or may-be even wrong? Comment 161: Line 394: "Devonian", Is it really Devonian rocks? O is it your Devonian to Permian or Devonian-Mississippian rocks? Comment 162: Line 398: "Grey Hoek and/or Wijde Bay formations", The Grey Hoek and Wijde Bay formations are only exposed in northern and central Andrée Land and not known further south. You can't interpret them being present in the Reinsdalspasset seismic section!! Comment 163: Line 399: "the Marietoppen Formation", The Marietoppen Fm is the equivalent of the Wood Bay Fm, not of the Grey Hoek and Wijde Bay formations!!! Comment 164: Line 415: "ö", o. Comment 165: Line 417: "ö", o. Comment 166: Line 420: “ö", o. Comment 167: Line 446: "Figure 4b and e", It is difficult to recognize Z-shaped geometries on Fig. 4b and 4e. Comment 168: Line 456: "ö", o. Comment 169: Line 465: “ö", o. Comment 170: Line 467: “ö”, o. Comment 171: Line 468: “ö”, o. Comment 172: Line 474: "4.2.3. Structures in Reindalspasset", Again Reindalspasset? See line 394. Comment 173: Line 488: "Grey Hoek and/or Widje formations", See above: there is no evidence that the Grey Hoek and Wijde Bay fms are exopsed south of Central Andrée Land. Comment 174: Line 514: "Cenozoic décollement (Eide et al., 1991;", There are much more colleagues who have mentioned and described the detachements in the Viséan to Lower Cretaceous sedimentary succession underneath the Central Tertiary Basin transfering the shortening from the WSFBT to the BFZ and LFZ. Why are you not refering to them? Comment 175: Line 517: "ö”, o. Comment 176: Line 524: “ö”, o. Comment 177: Line 525: “ö", o. Comment 178: Lines 530-543: "4.3 Adriabukta The results of the restoration of the western portion of the Adriabukta section of Bergh et al. (2011) are displayed in Error! Reference source not found.a-b. The restored sec- 
tion shows minor, meter- to tens of meter-scale normal displacement along a possibly Pennsylvanian-Permian fault offsetting the Pennsylvanian-Permian Hyrnefjellet and Treskelodden formations and terminating into the Upper Devonian (-Mississippian?) Adriabukta Formation. In addition, the erosional unconformity between the Adriabukta Formation and the overlying Hyrnefjellet Formation was restored to a flat-lying position by applying a $50^{\circ}$ counterclockwise rotation. As a result, the Mariekammen Shear Zone (Bergh et al., 2011), bedding surfaces within the Adriabukta Formation, and the stratigraphic boundaries between the Adriabukta Formation and Middle Devonian Marietoppen Formation and between the Marietoppen Formation and basement rocks in the west now dip steeply (ca. 65-70') to the east, seemingly forming the eastern flank of a kilometer-scale anticline (Error! Reference source not found.b). In addition, the Mariekammen Shear Zone now displays apparent down-east normal kinematics (Error! Reference source not found.b).", Have you worked in the Adriabukta area? If not, please delete this chapter. Or refer also to other geologists who have worked there and have a different opinian to Bergh et al. (2011). Comment 179: Lines 556-557: "This interpretation", Why interpretation? Seems to be an observation: In line 552 you say that the sediments of the Billefjorden Group ARE arranged in duplexes..... Comment 180: Lines 557-569: "is supported by minor Cenozoic thrusts crosscutting the Hultberget, Ebbadalen, Minkinfjellet and Wördiekammen formations in SassenfjordenTempelfjorden (Error! Reference source not found.a-b) that flatten downwards and die out within sedimentary strata of the Billefjorden Group (Error! Reference source not found.c), and by the presence of analogous shallow-dipping, bedding-parallel, duplexshaped décollements in uppermost Devonian-Mississippian coals and coaly shales sedimentary strata of the Billefjorden Group in Odellfjellet (Koehl and Muñoz-Barrera, 2018), in Robertsonbreen (between the uppermost Devonian-Mississippian Hørbyebreen Formation and Pennsylvanian-Permian Wördiekammen Formation; Di $\beta$ mann and Grewing, 1997), in northeastern Bjørnøya (Koehl, in prep.), at Midterhuken and in St-Jonsfjorden (where the unconformity between uppermost Devonian-Mississippian and Pennsylvanian sedimentary rocks possibly acted as a décollement; Maher and 
Welbon, 1992; Error! Reference source not found.a), in Nordenskiöld Land (Braathen and Bergh, 1995), and, potentially, in Oscar II Land (Bergh and Andresen, 1990) and Wedel Jarlsberg Land-Torell Land (Dallmann and Maher, 1989; Error! Reference source not found.a).", Wow: that is a long, long sentence! Just a comment: nobody is argueing against a Cenozoic deformation in the mentioned areas. And also the structures described in the Mississippian Billefjorden Group in the outcrop near the entrance of the Pyramiden Mine are Eurekan structures as suggested. But is this an argument against the Ellesmerian??!! How do the Eurekan structures on Bjoernoeya look like? As Koehl et al. is only in preparation, it is not a good argument to be used here. Comment 181: Line 558: “ö”, o. Comment 182: Line 564: “ö”, o. Comment 183: Lines 564-565: "Koehl, in prep.", This citation is missing in the reference list!!!! Comment 184: Lines 565: "-“, .. Comment 185: Lines 569-570: "Imbrication within the duplexes indicates top-west thrusting", Top to west? In all mentioned areas? Odellfjellet? Robertsonbreen? Bjoernoeya? Midterhuken? St.Jonsfjorden? Nordenskiöld Land? Oscar II Land? Wedel-Jarlsberg/Torrell Land? Really? Comment 186: Line 570: "early Cenozoic contraction-transpression",I don't understand the contraction-transpression: Comment 187: Line 574: "supporting our interpretation of Cenozoic thrusting in Pyramiden", I agree - no problem with Eurekan contraction in Pyramiden and along the BFZ. Comment 188: Line 577: "and/or Grey Hoek and/or Wijde Bay formations", No! Again: there is no Grey Hoek/Wijde Bay south of central Andrée Land!!! Comment 189: Line 586: "subduction margin in New Zealand (Morley et al., 2017, their figure 8).", Please do not compare the structures with a subductuion margin in New Zealand!!!! Or is the structures in the post-Tournaisian and younger rocks in central Spitsbergen related to subduction???? Comment 190: Lines 588-590: "Bråvallafjella Fold Zone (Piepjohn, 2000; Dallmann and Piepjohn, submitted) and southern Spitsbergen (e.g., Røkensåta; Error! Reference source not found.a; Dallmann, 1992),", Have you seen the structures in northern Andrée Land (Bravallafjella Fold Zone), on Germaniahalvoeya or in Soerkapp Land (Rökensata)? If not, how can you say that these structures are similar to the structures in Fig. $4 \mathrm{~b}$ and $4 \mathrm{e}$ ? By the way: I have really problems to recog- 
nize anything on the seismic sections: too small, too dark, no contrast. These figures are not suitable to support your thesis in the manuscript. Comment 191: Line 590: "supporting the presence of Devonian sedimentary rocks east of the Billefjorden Fault Zone in Reindalspasset", That is really dangerous!!! There are too many "if so"s...... Comment 192: Lines 594-595: "between shale and sandstone units of the Wood Bay and Grey Hoek formations in Andrée Land", Where are these décollements in Andrée Land? Comment 193: Line 614: "(Figure 4g)", Again: I am sorry but I can't see all the interpreted structures without a magnifying glass! Comment 194: Line 619: "Muñoz", Barrera. Comment 195: Line 621-622: "Cenozoic contraction-transpression", Is the observation that the Cenozoic deformation in Svalbard is dominated by "contractionaltranspressional" structures, solely based on your own field observations? I don't think so, and it would be important to refer to all the geologists who have done the work before. You also should talk about the controversial discussion in the literature: is the Eurekan characterized by a) contraction, b) transpression, c) decoupling, or d) two phases with contraction first and dextral strike-slip second? Comment 196: Lines 622624: "thus supporting the presence of such décollements in Pyramiden (Fig. Error! Reference source not found.b), Sassenfjorden-Tempelfjorden (Fig. Error! Reference source not found.a-f) and Reindalspasset (Fig. Error! Reference source not found.g).", I completely agree with you. However, the Cenozoic contractional deformation in postAndrée Land Group deposits between the areas of the WSFTB and the BFZ and LFZ is well known since the end of the 80 s! You should mention all those authors. Reading this manuscript, the feeling apperas that you are the frist one. Comment 197: Line 625: "Uppermost Devonian-Mississippian coal-rich strata are locally thicker in Pyramiden", There is a number of publications on the development of the Billefjorden Trough that should be mentioned here. It's is not only Livshitz, Cutbill and yourself. Comment 198: Line 631: "Ottar Basin", Where is the Ottar Basin? Comment 199: Line 631: "Finnmark Platform", Is the equivalent of the Billefjorden Group really named Billefjorden Group on the Finnmark Platform as well? Comment 200: Lines 632-633: "show that uppermost Devonian-Mississippian sedimentary", There is a number of colleagues who

Interactive comment
Printer-friendly version

Discussion paper

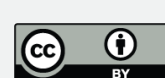


have worked in the structural and sedimentological evolution of the Billefjorden Trough - again, the feeling appears that almost nobody has done anything in this area except for you. Comment 201: Lines 639-640: "Iocalization of contractional duplexes and décollements", The concentration of contractional structures can also be a result of pre-existing faults and their reactivation. Comment 202: Lines 649-650: "probable that Devonian sedimentary deposits were folded in Cenozoic times", Yes, it is of course possible that Devonian sediments were again deformed during the Eurekan deformation. But what's about the kilometer-scale fold-structures of the Dicksonland Fold-and-Thrust Zone directly west of the BFZ in central Dickson Land? They are unconformably overlain by deposits of the Billefjorden Group along a high-angle unconformity. Have you observed the entire base of the Billefjorden Group throughout central Dickson Land to check if the contact is sedimentary or tectonic? Our 1:10.000 scale mapping of central Dickson Land in 1996 has shown that the base of the Billefjorden Group on top of the deformation Devonian rocks is sedimentary. If a different tectonic style between the strongly folded Devonian and the higher post-Devonian rocks would be the result of the decoupling during a single, Eurekan deformation, the boundary between Billefjorden and Andrée Land groups should be an important décollement which would represent a regional and well visible structure. Comment 203: Lines 659-662: "noticed that sedimentary strata of the Upper Devonian Plantekløfta Formation and uppermost Devonian-Mississippian Hørbyebreen Formation are both similarly folded, i.e., suggesting that Cenozoic transpression may be (at least partially) responsible for folding of Devonian rocks in central Spitsbergen.", As stated above: nobody questions the fact that Devonian deposits maybe party affected by the Eurekan deformation. But this is not an argument to eliminate the Ellesmerian. Comment 204: Line 672: "ö", o. Comment 205: Line 681: "Devonian sedimentary rocks (Figure 2)", What do you mean with the backward-dipping duplexes? Are they located in the Mimerdalen Subgroup? Do you mean the large-scale fold structures west of Pyramiden? Or are you talking about structures directly in Pyramiden? In this case, the deposits should belong to the Wood Bay Formation. But in this case, the citation Piepjohn (2000) would be wrong: 
I have never stated that the folds directly below the BFZ are Ellesmerian - I couldn't do that because I haven't worked in this area directly at the Balliolbreen Fault (except for the area in Garmdalen and Nidedalen). And the presence of Eurekan structures in the footwall of a fault which was reactivated during Eurekan, is not surprising, and we have, again, never argued against Eurekan structures near the large faults of the BFZ. Comment 206: Lines 686-689: "This is supported by field studies (Fard et al., 2006) and analog modelling (Bahroudi and Koyi, 2003) in the Zagros Fold-and-Thrust Belt showing buttressing, backward-dipping duplexes and décollements in the hanging wall of deep-seated faults, and by analog modelling of décollements in soft sedimentary layers with limited lateral extent (Costa and Vendeville, 2002, their model 3).", I am not convinced that the structural style in the vicinity of the BFZ and west of it is comparable to the Zagros Fold-and-Thrust Belt! Just a little question: what have you seen from the large folds and thrusts west of the BFZ in central Dickson Land? Have you ever seen the steep limbs of the large fold structure in Nidedalen, Garmdalen and Alvrekdalen overlain by undeformed Wordiekammen Formation? Without evidence for tectonic movements along the unconformity? Comment 207: Lines 694-695: "Balliolbreen Fault in Pyramiden", Wasn't the location of the Balliolbreen Fault "in Pyramiden" already described and shown on the maps by Harland et al. (1974)? Comment 208: Lines 715-717: "basin-bounding normal faults, and ramp up into soft, syn-rift sedimentary strata, potentially using décollement levels to accommodate contraction", I agree. But it is also possible that pre-existing, west-directed Ellesmerian reverse faults were re-activated during Eurekan, not only post-Devonian normal faults. Comment 209: Lines 733-736: "(Carboniferous sedimentary strata) remains essentially the same, whereas the length of the floor sequence (Devonian sedimentary rocks) decreases through intense folding (Bonini, 2001), which may (partially) explain the significant differences of deformation between folded Devonian and Mississippian-Permian strata", I am confused about your unprecise age determination: here, you are talking baout Carboniferous sedimentary strata and Devonian sedimentary rocks. Which sedimentary sequences do you mean? Andrée Land Group and Billefjorden Group? 
But throughout the manuscript you argue that the Billefjorden Group is Devonian to Mississippian in age. That is difficult to understand.... And the mentioned significant differences of deformation between the Devonian Andrée Land Group and the less deformed Carboniferous Billefjorden Group (only local deformation in the vicinity of the BFZ and LFZ) can be better explained by the existence of a folding event between both sedimentary units. Comment 210: Line 748: "This model", I would not call it a modell, when you are talking about an interpretation, which might be.... Comment 211: Line 806: "post-Caledonian gravitational collapse processes", Chorowicz (1992) is the only one who has interpreted gravitional collapse processes in northern Andrée Land. As I remember correctly, Chorowicz (1992) described the entire Andrée Lansd Basin as being tilted towards the east resulting in East-directed collapse structures. All other geologists have described contractional structures in the Andrée Land Basin related to west-directed tectonic movements towards the west. Comment 212: Line 807: "Woodfjorden detachment in Andrée Land", I can't see the Woodfjorden detachment in Andree Land on Fig. 1a! And how does the Woodfjorden detachment looks like? Roy et al. (unpublished) is not a good argument and reference! You should describe the Woodfjorden detachment here, and you should also discuss why it is possible to correlate the very small-scale, local detachments in the outcrop in Fig. $3 \mathrm{~b}$ and the Woodfjorden detachment which is far away. Comment 213: Line 809: "or formed as a minor, bedding-parallel Cenozoic accommodation thrust", I again agree that a lot of structures you have observed, especially in the post-Devonian Billefjorden Group, are Eurekan structures. Only refering to Chorowicz (1992) indicating that all deformation in Andrée Land is related to gravitational collapse, your arumentation seems to be reasonable to say that there is no Ellesmerian deformation. But you are ignoring the fact that huge parts of Andree Land and the basement areas at the west coast (Mitrahalvoeya, Blomstrandhalvoeya) are affected by contractional structures - and it is not correct just to ignore all these structural works and publications. Comment 214: Line 810: "Thus, it is probable that the Balliolbreen Fault does not crop out or is not present in Pyramiden.", I have not understood why it is probable that the Balliobreen

Interactive comment
Printer-friendly version

Discussion paper

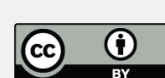


Fault does not exist near the entrance of the Pyramiden Mine. Comment 215: Lines 824-825: "The presence of Devonian sedimentary rocks east of the Billefjorden Fault Zone", The observation that Devonian rocks are exposed east of the BFZ would be extremely important. But is the interpretation of the seismic section in Fig $4 \mathrm{~b}$ enough to support this? There is no real control because drillings are missing east of BFZ in this area. Comment 216: Line 829: "on previous work", What kind of previous work? Comment 217: Lines 851-852: "Devonian sedimentation sourced from the collapsing orogen and exhuming core complexes", The Devonian sedimentation was sourced from exhuming core complexes?? Several core complexes??? Braathen et al. have only interpreted ONE core complex. However, the existence of core complexe(s) is not very well constrained and supported by geological mapping data and structural data. This modell also ignores the published sedimentology works. The source for the rocks of the Andrée Land Group (Austfjorden Fm) and Mimerdalen Subgroup was situated east of the BFZ, which means that there was a Devonian cover above the basement rocks of $\mathrm{Ny}$-Friesland which was completely eroded there between the sedimentation of the Mimerdalen Subgroup and the deposition of the Billefjorden Group in the outcrops east of BFZ up to Mosselbukta indicating an important stage of tectonics between noth units. That can be, of course, related to major extension and a downthrow to the east in the Tournaisian - or to an ulift of the basement rocks in the east on top of the ORS west of BFZ - which would be the Ellesmerian. And this is porved by the formation of the kilometers-scale foldstructures and reverse faults in Mimerdalen area, which are unconformably overlain by the Billefjorden Group. Comment 218: Lines 879-900: "Notably, the significant [...]", This sentence down to line 900, is very difficult to understand! Comment 219: Line 883: "ör", o. Comment 220: Line 885: "ö", o. Comment 221: Line 887: "r", o. Comment 222: Lines 901-903: "Segmentation of the Balliolbreen [...]", This sentence, down to line 914, is again difficult to understand. Comment 223: Line 902: "kilometer-scale, left-lateral offsets of the Balliolbreen Fault in Billefjorden and Sassenfjorden", Where are the kilometer-scale left-lateral strike-slip zones displacing the Balliobreen Fault in Billefjorden and Sassenfjorden??? I can't

Interactive comment
Printer-friendly version

Discussion paper

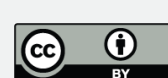


remember that there are such WNW-ESE striking faults on the geological maps. Comment 224: Line 920: "may be explained by (partial) strain decoupling during Cenozoic transpression",.....it MAY be explained by Cenozoic transpression..... Comment 225: Line 923: "Figure 3c", I can't see very much on Fig. 3c! It does not show your arguments and interpretation. Comment 226: Lines 923-924: "conceivable that, there too, the base of the Billefjorden Group consists of highly deformed, coal-rich sedimentary rocks", Be careful! Have you seen the base at Triungen? You say that the base of the Billefjorden Group at Triungen es covered by black scree (suggesting that it maybe highly deformed) but nobody has seen and described that this base is really highly tectonized. Therefore, you cannot use such kind of assumption, and it is therefore dangerous, to argue that the base of the Billefjorden Group is highly deformed in other ares!!! Comment 227: Line 927: "structural setting at the Triungen locality is, indeed, very similar to that in Pyramiden", No, it is different. You can't compare both outcrops, when you haven't seen both!!! Comment 228: Line 932: "It is therefore possible that the Triungen-Grønhorgdalen Fault Zone might", Your argumentation is a little bit weak: therefore possibly, might be..... Comment 229: Lines 938-940: "may indicate the presence of thick coal seams and/or coaly shales along the Triungen-Gronhorgdalen Fault Zone and, conceivably, of bedding-parallel décollements, thrusts and duplexes similar to those in Pyramiden (Fig. Error! Reference source not found.b).", The presence of coal seams and coaly shales (which are present at Triungen at the base of the Billefjorden Group above the tilted Devonian) is proved and was mapped, described and dated by Grewing and Dißmann. There is post-Ellesmerian deformation along the Groenhorgdalen-Triungen Fault, but it is a post-Ellesmerian sinistral strike-slip fault. Comment 230: Line 943: "Figure 1b", I can't recognize the faults in Fig. 1b! Comment 231: Line 947: “ö", o. Comment 232: Lines 947-948: "is more likely to correspond to a Devonian low-angle normal fault or detachment or to an unconformity", Have you seen these outcrops? How many structural observations have you made in this area? Have you carefully mapped this area? The unconformity of the Wordiekammen Fm in this area is NOT a low-angle normal fault and is NOT a detachment! Have you 
ever seen the contacts of the Wordiekammen Fm and the Billefjorden Group on top of the folded Devonian? Have you visited these places proving of these boundaries are sedimentary of tectonic? If not, you should NOT use the boundary in this area as an argument for your interpretation. It is not a good scientific way to use such "arguments" only because this would support your interpretation. Comment 233: Lines 949-951: "The lower Munindalen thrust is similar to post-Caledonian extensional detachments mapped in Andrée Land, e.g., the Woodfjorden detachment", NO, the lower Munindalen thrust is absolutely not similar to the so-called Woodfjorden detachment - the latter is only interpreted by Chorowicz and is nowhere exposed on land!! Comment 234: Line 952: "low-angle and show syn-kinematic fault-related folding within Lower-Middle Devonian", Have you or anyone else done structural analyses along the Munidalen Thrusts? You are always refering to weak arguments of publications (or even unpublished work) and then transfer these weak arguments to any faults in the Mimerdalen area without having done own structural studies along those faults. That is not the way for an honest scientific argumentation. Comment 235: Lines 955-956: "rocks like, e.g., Givetian (upper Middle Devonian) rocks of the Widje Bay Formation that lie unconformably over folded Eifelian (lower Middle Devonian) strata of the Grey Hoek Formation", Where are these intra-Devonian unconformities and detachments exposed - where are they described expect for Roy (2007) and Roy (unpublished)? Comment 236: Lines 959-961: "The presence of extensional shear zones in Devonian rocks in central Spitsbergen was also evidenced by Michaelsen et al. (1997, their figure 5a) and Michaelsen (1998, her figures 44 and 45) in Munindalen (Error! Reference source not found.b).", You can't use this references for your interpretation. It is a wrong citation: we have interpreted these steeply SW-dipping, SW-directed shear zones as contractional detachments during an early stage of the Ellesmerian! WE HAVE NEVER TALKED ABOUT EXTENSIONAL SHEAR ZONES!!!!! Comment 237: Lines 964-965: "However, this thrust is not unconformably overlain by post-Devonian sedimentary rocks in Munindalen (Error! Reference source not found.b", The lower Munindalen Thrust is not unconformably overlain by Carboniferous rocks at the place. 
But it is overthrust by the upper Munindalen Thrust in the south and morges with the upper Munindalen Thrust on the north, where the merged Munindalen Thrust(s) are unconformably overlain by Carboniferous. Comment 238: Line 966: "probable", Again probable! Your observations seem never to be evidence..... Comment 239: Line 969: "ö", o. Comment 240: Lines 972-973: "see the alignment in Figure 1b", Where is this alignment? I can't see it. Comment 241: Line 973: "represent the same fault", Again: Shall these two thrusts.... it is an assumption. Both thrusts do not represent the same fault. Comment 242: Line 975: “ö”, o. Comment 243: Lines 975-976: "the relatively undeformed character of uppermost Pennsylvanian-lower Permian rocks in Kilen (Error! Reference source not found.b)", I can't see it on Fig. 1b. Comment 244: Lines 977-979: "e.g., at the base of the Wördiekammen Formation. Cenozoic décollements are indeed common in uppermost Pennsylvanian-Permian sedimentary rocks", This is really dangerous: your assumption is that the base of the Wordiekammen Fm is a common, Eurekan detachment fault between the folded and tilted Devonian and the Carboniferous. Can you please give me a single example for a detachment west of the Balliolbreen fault underneath the horizontal Carboniferous based on field observations and structural field work???!!! Comment 245: Line 977: "ö", o. Comment 246: Line 979: “ö", o. Comment 247: Line 981: "Brøggerhalvøya (Bergh et al., 2000; Saalmann and Thiedig, 2000)", You can't compare the situation in Dickson Land with the situation on Broeggerhalvoeya. Comment 248: Line 984: "ö", o. Comment 249: Line 987: "ö", o. Comment 250: Line 988: "Piepjohn (2000)", I don't understand this citation! I have used the argument on the constant level of the Carboniferous to infer a Late Devonian age of the Munindalen Thrust? I am sure that I didn't say this! Our dating of the Munindalen Thrust is based on the formation of the Dickson Land Fold-Thrust Zone PRIOR to the sedimentation of the Carboniferous rocks, Without a detachment along the base of the Carboniferous! Comment 251: Line 990: "ö", o. Comment 252: Lines 992-993: "possible connection between the Munindalen and Robertsonbreen thrusts", See above: following our mapping on 1996, the Munindalen and Robertsonbreen thrusts represent different structures. This is again an assumption based on 
an assumption. Comment 253: Line 998: "transpression", Now you are talking about transpression - a little bit further up you have talked about Eurekan contraction. Comment 254: Line 1000: "The", the. Comment 255: Lines 1003-1004: "the contact of the Blåvatnet Reverse Fault with Pennsylvanian-Permian sedimentary deposits of the Wördiekammen Formation is not exposed", First of all: the contact of the Blavatnet Reverse Fault unconformably overlain by Carboniferous is indicated on our Fig. 13, and in the north, it is truncated by the lower Munindalen Thrust that is truncated by the upper Munindalen Thrust that is unconformably overlain by Carboniferous. Secondly: the geological map clearly shows that the Dickson Land fold-and-thrust zone as a whole is overlain by Carboniferous rocks, and the Carboniferous rocks on top are mostly undeformed. Just looking at faults in the Mimerdalen area that are maybe not overlain by Carboniferous for justifying the own modells is not correct and not fair. Having a look at the existing geological maps, it is obvious that the steeply inclined reverse faults do not cut through the horizontal Carboniferous and younger cover. Again: we agree and confirm the possibility of Eurekan reactivation, but the big sub-Carboniferous deformation is pre-Carboniferous. Taken into account your modell of sub-Wordiekammen detachments, it is a little bit strange, that, in this case, all the steep faults in the Devonian turn into horizontals detachments at the base of the Carboniferous. That is not so easy to explain. Comment 256: Lines 1019-1020: "Other arguments against the occurrence of the Ellesmerian Orogeny are the restricted extent of presumed Ellesmerian deformation belts (Piepjohn, 2000)", Why is this an argument against the Ellesmerian deformation? It can also be an argument against Eurekan deformation! The fact that there are deformation belts and partly less or undeformed areas is not an argument for the age of the deformation. And taking the Pretender Mountain as an argument is very weak again: this area is one of the areas between the Ellesmerian deformation zones. It should be mentioned, that a number of the less-deformed areas between the deformation belts are still affected by fracture cleavage formation indicating west-directed transport directions. It should be also mentioned that there are two deformation zones in the crystalline basement at the west coast of Spitsbergen north of Kongsfjorden:

Interactive comment
Printer-friendly version

Discussion paper

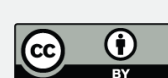


Blomstrandhalvoeya and Mitrahalvoeya deformation zones, which are characterized by tectonic transports to the west as well - the Cenozoic deformation in this area is characterized by NE-directed transports in contrast to the West-directed transports in the footwall of the WSFTB at Broeggerhalvoeya. Comment 257: Line 1023: "ö", o. Comment 258: Line 1025: "it would most likely have folded Devonian strata throughout Spitsbergen", No, that is not necessary - Based on your conclusions that the Ellesmerian does not have affected Spitsbergen, we can formulate the sentence related to the Eurekan deformation: "If Eurekan contraction-transpression had occurred, it would most likely have folded Devonian strata throughout Spitsbergen". By the way, apart from the less deformed zones, the entire area of NW-Spitsbergen is affected by Wdirected folding, thrusting and cleavage formation between the BFZ and the west coast of Albert I Land. The explanation is given by the possible existence of a deep-seated Ellesmerian detachment with upramping reverse faults, probably due to pre-existing faults that can explain the occurrences of the Ellesmerian deformation zones. Comment 259: Lines 1026-1029: "Hence, a probable alternative is the exhumation of a 25 km-wide, N-S- to NNW-SSE-trending core complex in Devonian-Mississippian times, the Bockfjorden Anticline (Braathen et al., 2018), which possible continuation to the south aligns with the Pretender Mountain.", No!!! You cannot compare the Pretender Fault with the assumption of the core complex by Braathen et al.! The Pretender Fault is a post-Carboniferous and probably also a post-Eurekan fault: it cuts though Eurekan structures of the WSFTB. Again: do you have ANY field data and structural data from the Pretender Fault which support the core complex??? Comment 260: Lines 10311034: "absence of uppermost Devonian-Mississippian sedimentary rocks of the Billefjorden Group may be explained by continued exhumation of the Bockfjorden Anticline in the Late Devonian-Mississippian, thus exposing the area to continental erosion in latest Devonian to Mississippian times (Koehl, 2019; Koehl et al., in prep.)", I am more and more frustrated about the assumptions presented in this manuscript: there are correlatives of the Billefjorden Group on Broeggerhalvoeya and further south. Have you ever heard about the Nordfjorden High between the St. Jonsfjorden and Billefjorden 
Troughs? On top of the Nordfjorden Block, the Billefjorden Group is absent, but it is not an argument for the absence of the Ellesmerian deformation! Comment 261: Line 1038: "2015", 2016. Comment 262: Lines 1038-1039: "thus making it a reasonable alternative to the Ellesmerian Orogeny", But only, if the geological mapping and structural observations are correct. The fact is that most of the contacts between the base of the ORS and the underlying basement in the Liefdefjorden area are not tectonic but sedimentary: in northern Spitsbergen, the Devonian Red Bay Group unconformably overlies carstified and heavily weathered marbles without any tectonic structures. Only in the west and east of the Bockfjorden Anticline, the contact Red Bay Group/Basement is represented by tectonic boundaries - but not by a detachment: in the east it is a postDevonian normal fault (not a detachment), and in the west it is an east-directed (not north-directed) reverse fault (Friedrichbreen Fault) which can be interpreted as possible Eurekan structure. Braathen et al. have ignored the characteristic of the E-W shortening oni this area, which has affected the Devonian deposits. In contrast: there are no kinematic indications for northwards movements within the Devonian (only some brittle sinistral slickenside lineations on steeply W-dipping faults which can be either represent north-directed movements before tilting or a real sinistral strike-slip fault - that should be discussed). In addition, there are N-S trending lineations in the underlying basement rocks, which are related to ductile movements before the Devonian - the ductile shear zones nowhere cut through the Devonian/basement boundary. Comment 263: Lines 1041-1042: "(Piepjohn and Dallmann, 2014)", Why are you citing us????? We have never said that the coarse-grained conglomerates of the Mimerdalen Subgroup are related to a speculative core complex!! The conglomerates are related to uplift east of BFZ! Comment 264: Line 1048: "breccia yielding", It is not a breccia but calcareous sandstones which have filled the caves. Comment 265: Line 1062: "NW-", I can't remember that they have described NW-directed thrusts: ....predominantly W-directed thrusting. Comment 266: Line 1065: "NW-verging thrusts seem to have formed in the Cenozoic", How can you say that the NW-verging thrusts on Blomstrandhalvoeya (which do not exist!) seem to have formed during Cenozoic deformation? DO YOU

Interactive comment

Printer-friendly version

Discussion paper

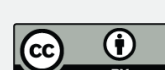


Spitsbergen was partitioned and that Brøggerhalvøya and Blomstrandhalvøya are separated by a major NW-SE-striking, sinistral-reverse oblique-slip fault that extends from Kongsfjorden to Sassenfjorden and the northern Barents Sea", First of al: is this based on your own work that Broeggerhalvoeya and Blomstrandhalvoeya are separated by a NW-SE striking sinistral reverse fault?? Do you have any evidence for this assertion? Is there any evidence for such a fault on land??? Have you or the other workers have ever found such structure connecting Kongsfjorden and Sassenfjorden and have you done structural geology at this structure? Where is this large NW-SE strike-slip fault on the geological maps? Does it truncate through the well-known seismic sections in Isfjorden? Just for your information: we haven't found any structural evidence for a NW-SE sinistral strike-slip fault on Broeggerhalvoeya, on Blomstrandhalvoeya or in any other areas SE of Kongsfjorden. But maybe, our observations are not serious enough..... Comment 268: Lines 1069-1070: "marbles are poorly deformed on Blomstrandhalvøya, especially in the westernmost part of the peninsula where", That is not correct!!!! Blomstrandhalvoeya is affected by a number of West-directed thrust faults affecting basement marbles and Devonian Red Bay deposits. The areas between the thrusts are mostly undeformed but partly affected by an Ellesmerian fracture cleavage S3. The Carboniferous cave rocks are absolutely undeformed indicating that the reverse fault deformation took place before the carstification and Carboniferous transgression. Comment 269: Line 1082: "(Piepjohn et al., 2000)", Please do not cite my work in this context!!!!! Comment 270: Lines 1085-1087: "which recently yielded early Frasnian (ca. $380 \mathrm{Ma}$ ) ages based on fossil and spore assemblages for both formations (Berry and Marshall, 2015)", Berry and Marshall do not like our age determination. But the findings of just a few Famennian spores and the fact that the Late Devonian rocks, fossils and spores have survived erosion and redeposition indicate a younger age of the upper Mimerdalen Subgroup. And the oldest spores in the overlying Billefjorden Group are Viséan. This means that there is much more time for the Ellesmerian defor- 
mation than suggested by yourself There are age determinations for the Ellesmerian deformation on Ellesmere Island and Melville Island which also indicate Tournaisian age of the Ellesmerian deformation. It is also supported by Beauchamp et al. 2018 who have worked on the Okse Bay Formation which was, as the Billefjorden Group before and by Berry and Marshall, dated as being Middle to Late Devonian in age due to eroded and resedimented spores. This supports a Latest Devonian to Tournasian age for the Ellesmerian deformation. In edition, there are new ages for amphibolite metamorphism on Prins Karls Forland at ca. $360 \mathrm{Ma}$. That is the highest Ellesmerian metamorphism ever descivered. What should be the reason for this high metamorphism if the tectonic regime was extensional as you are suggesting? Comment 271: Lines 1097-1100: "Despite the slight difference of plunge, the two fold populations distinguished by Bergh et al. (2011) are not significantly different from one another, and may actually reflect the same episode of Cenozoic contractional-transpressional deformation, which was also suggested by Dallmann (1992)", But Bergh et al. have never seen the large-scale fold-structures in the Devonian south of Hornsund which are unconformably overlain by Triasssic? In addition: the folding in the Marietoppen and Adriabukta Fm at Adriabukta is signifcantly different to the Tertiary deformation observed in the post-Devonian sedimentary succession in the Soerkapp Land area. Comment 272: Lines 1105-1106: "Upper Devonian (-Mississippian?) sedimentary strata of the Adriabukta Formation", As also Bergh et al. have stated: the Adriabukta Fm is probably a correlatve of the Mimerdalen Subgroup and therefore most likely represents the uppermost succession of the Devonian basin. Comment 273: Lines 11251126: "two dolerite sills are Late Devonian-Mississippian in age", What's about a Late Cretaceous age of the sills??? Comment 274: Lines 1128-1129: "Thus, it is more probable that the two dolerite sills in Adriabukta are part of the Cretaceous Diabasodden Suite (Senger et al., 2013)", OK - please remove the assumption of the assumption of Late Devonian-Mississippian above! Comment 275: Lines 1135-1137: "gently dipping Lower Triassic sedimentary rocks overlie folded Devonian strata and, therefore, potentially support Late Devonian Ellesmerian transpression", Can't see it on Fig. 1 
Comment 276: Lines 1143-1145: "décollement or roof/floor-thrust in Triassic shales may have decoupled Cenozoic deformation between folded Devonian and overlying gently dipping Lower Triassic sedimentary strata in Røkensåta", I am really more and more frustrated: There are so many observations, mapping and structural fieldwork done from older geologists who have mostly very good arguments for their geological interpretation. But suddenly there is someone who has never ever seen all the outcrops between Woodfjorden and Soerkapp but states that all the previous geologists are not correct, that their mapping was wrong, that they have undertaken wrong interpretations and wrong observations, and that they have made thousands of wrong structural measurements. Do you think that a geologist like, for example, Winfried Dallmann, has no experience with mapping and that he has always failed to interpret the contacts as unconformities instead of detachments. Are you, in contrast, able to claim that all the contacts are interpreted wrongly because they don't fit in your model??? Again: have you visited all these outcrops and have made new field observations? If so, you would be possibly able to judge your assertion. But I have a lot of doubts that you really can judge what all the other geologists have done over the last 30 years. Instead, you are just presenting so many "maybe's", "perhapses", "possibles", "more likelys"! Comment 277: Line 1156: "(e.g., in Andrée Land; Roy, 2007, 2009; Roy et al., unpublished)", Again: please show me those publications. I would be very curious to see the extensional detachment in Andrée Land. Why isn't it published in serious, peer-reviewed journals? Comment 278: Lines 1158-1159: "might be a potential contractional event in the Permian-earliest Triassic (Uralian Orogeny?)", Oh yes! Why not creating a new Orogeny in Svalbard based on very poor field data!!! Comment 279: Lines 1163-1166: "trends parallel in map view and cross-section to the contacts between the (Upper Devonian-Mississippian?) Adriabukta and (Lower-Middle Devonian) Marietoppen formations and between the Marietoppen Formation and Neoproterozoic basement rocks in the west, shows a eastward dip", Is this based on and reflects real field observations? Comment 280: Lines 1175-1179: "A possible trigger for the steep eastward dip of Devonian (-Mississippian?) sedimentary strata of the Mariekammen and Adriabukta 
formations (after restoration) in Adriabukta (Error! Reference source not found.aError! Reference source not found.) may be core complex exhumation of Neoproterozoic basement rocks in the west (Error! Reference source not found.a-d), as observed in central (Koehl, 2019; Koehl et al., in prep.) and northwestern Spitsbergen (Braathen et al., 2018).", !!!You really take the asssumed eastward dip of the Marietoppen and Adriabukta fms as an indication and evidence for a core complex??? Comment 281: Lines 1180-1181: "might represent a large clast that was eroded from a basement culmination", Again: might - this is a strange speculation! Comment 282: Lines 11821184: "along a bedding-parallel, core complex-bounding detachment in the west in Devonian-Mississippian times (Error! Reference source not found.b2), comparable to the Woodfjorden detachment (Roy et al., unpublished)", I am speechless....... Comment 283: Line 1187: "a”, Haitanna Comment 284: Lines 1188-1192: "Core complex exhumation in the Devonian may also explain the absence of the Marietoppen Formation between basement rocks and strata of the Adriabukta Formation on Påskefjellet, south of Hornsund (Dallmann, 2015; Error! Reference source not found.a), if this area represents the crest of the proposed core complex that was exhuming in the Devonian (Error! Reference source not found.b-d).", There are much more explanations for therefore, that have been already published and are much better based on geological and structural field observations and mapping. Comment 285: Line 1193: "eastern flank of this proposed core complex", Again: this is really very weak. DO YOU HAVE ANY STRUCTURAL EVIDENCE FOR A CORE COMPLEX IN THIS AND OTHER AREAS? Comment 286: Lines 1193-1194: "likely offset left-laterally by a WNW-ESE-striking fault in the fjord", Now we have another structure!! Do you have any evidence for a WNW-ESE sinistral strike-slip fault in Hornsund? Is there any serious arguments on the geological maps or in the published papers? Comment 287: Line 1201: "Examples of such folds have been documented in Andrée Land", What do you mean? Comment 288: Lines 1205-1208: "Notably, in eastern Canada and California, such folds are associated with the exhumation of metamorphic core complexes (Fletcher and Bartley, 1994; Schwerdtner et al., 2016), thus suggesting that folds in Devonian rocks in Spits- 
bergen (e.g., in Røkensåta; Error! Reference source not found.a) might have formed during Devonian-Mississippian core complex exhumation. A", You really try to get your arguments for your interpretation from all over the world?? My question: how much of this paper is really based on structural field work and mapping? And how many measurements? I have seen that all your interpretation is based on 133 measurements in one little outcrop. And do you think that the visit of a tiny little outcrop is enough to present so many assumptions? Comment 289: Lines 1209-1210: "Ellesmerian structures in southern Spitsbergen is further supported by their NW-SE to NNW-SSE trend (Bergh et al., 2011, their", Are you talking about the outcrop in tghe Adriabukta Fm in Adriabukta? If so: this is no transpressional folds!!! The ENW-ESW shortening is also supported by reverse faults, and the entire outcrop is affected by penetrative cleavage S1 and crenulation cleavage S2. Based on around 500 measurements. Comment 290: Line 1404: “30 pp.", 255-284. Comment 291: Line 1404: “2019”, 2018. Comment 292: Lines 1848-1860: "Roy, J.-C., L. G.: La géologie du fossé des Vieux Grès Rouges du Spitzberg (archipel du Svalbard, territoire de l'Arctique) - Synthèse stratigraphique, consequences paléoenvironnementales et tectoniques synsédimentaires, Mémoires des sciences de la Terre de l'Université Pierre et Marie Curie, Ph.D. Thesis, Pierre and Marie Curie University, Paris, France, 2007-15, 242 pp., 2007. Roy, J.-C.: La saga des vieux grès rouges du Spitzberg (archipel du Svalbard, Arctique): Une histoire géologique et naturelle, Charenton-le-pont: Auto-Edition Roy-Poulain, 290 pp., 2009. Roy, J.-C., Chorowicz, J., Deffontaines, B., Lepvrier, C. and Tardy, M.: Clues of gravity sliding tectonics at the Eifelian-Givetian boundary in the Old Red Sandstone of the [late Silurian?]-Devonian trough of Andrée Land (Spitsbergen), in: La saga des vieux grès rouges du Spitzberg (archipel du Svalbard, Arctique): Une histoire géologique et naturelle, edited by: Charenton-le-pont: Auto-Edition Roy-Poulain, Norw. J. Geol., unpublished.", behind Roberts (1983). Comment 293: Line 1870: "2001", 2000. Comment 294: Lines 1877-1881: "Schneider, D. A., Faehnrich, K., Majka, J. and Manecki, M.: 40Ar/39Ar geochronologic evidence of Eurekan deformation within the West Spitsbergen Fold and Thrust Belt, in: Circum-Arctic Structural Events: Tectonic Evolution of 
the Arctic Margins and Trans-Arctic Links with Adjacent Orogens, edited by: Piepjohn, K., Strauss, J. V., Reinhardt, L. and McClelland, W. C., GSA Special Paper, 541, 1-16, 2018.",behind Schmiedel et al. Comment 295: Lines 1903-1905: "Steel, R. J. and Worsley, D.: Svalbard's post-Caledonian strata - an atlas of sedimentational patterns and palaeogeographic evolution, in: Petroleum Geology of the North European Margin, Norwegian Petroleum Society (NPF), Graham and Trotman, 109-135, 1984.",is not cited in the text!!! Comment 296: Lines 1959-1960: "(dotted orange lines)", The colours of the lines are difficult to recognize: thicker! Comment 297: Lines 19611966: "Dashed lines represent lithostratigraphic transition from red and green Lower Devonian sandstone (Wood Bay Formation) to Devonian quartzite and dark sandstone (dashed orange), from Devonian quartzite and dark sandstone to uppermost Devonian-Mississippian sedimentary rocks of the Billefjorden Group (dashed yellow green), and from the Billefjorden Group to strata of the Gipsdalen Group (dashed blue green).", Does it mean that the contacts between (i) Lower Devonian sandstone, (ii) Devonian quartzite and dark sandstone, (iii) uppermost Devonian-Mississippian sedimentary rocks of the Billefjorden Group and (iv) strata of the Gipsdalen Group are sedimentary contacts? Or are the contacts faulted? Comment 298: Lines 1969-1971: "near the boundary between Lower Devonian and uppermost Devonian-Mississippian sedimentary rocks.", is this boundary a sedimentary ocntact or a fault? The red line indicates a tectonic contact? Comment 299: Line 1972: "fracture surfaces", What do you mean with "fracture surface"? Joints? Cleavage? Shear planes? If shear planes: are there any kinematic indicators like slickenside lineations? Comment 300 : Line 1974: "fracture surfaces", Any kinematics? Strike-slip? Normal? Reverse? No slickenside-lineations? Comment 301: Line 1975: "fracture surfaces", Any kinematics? Strike-slip? Normal? Reverse? No slickenside-lineations? Comment 302: Line 1979: "lithostratigraphic contacts", This means that all boundaries are lithologic sedimentary boundaries? Comment 303: Line 184: "surface", plane. Comment 304: Lines 19851986: "bedding surface measurements in the Billefjorden Group as contoured poles", Wow: 23 measurements of bedding planes! and they are all indicated on the map! Rhe 
few measeurements of bedding planes and "fracture surfaces" without any indication of kinematics is not enough for a structural analysis presented in this manuscript. Comment 305: Lines 1994-2000: "Satellite image from toposvalbard.npolar.no showing the inferred trace of the Triungen-Grønhorgdalen Fault Zone in Triungen (Error! Reference source not found.b), which juxtaposes folded Lower Devonian sedimentary rocks of the Wood Bay Formation (bedding in orange) against uppermost Devonian-Mississippian strata of the Billefjorden Group that are unconformably overlain by the Wördiekammen Formation. The right hand-side inset shows a zoomed-in portion of the fault displaying dark-colored screes that may represent coal near the base of the Billefjorden Group in the hanging wall of the fault.", Figure $3 \mathrm{c}$ is not necessary and is not an explanation for your conclusions. Comment 306: Figure 4: "', What does the scale mean???? Comment 307: Line 2002: "Figure 4: Seismic sections", Where is the assumed Devonian (Andrée Land Group) sediments described in the text east of the BFZ in these sections? Comment 308: Lines 2007-2008: "Zoom in SW-verging, coal-bearing duplexes acting as top-SW décollements in thickened, uppermost Devonian-Mississippian sedimentary deposits;", That is also difficult to see Comment 309: Line 2008: "NW-SEstriking", How do you know that the thrusts strike NW-SE in a two-dimensional seismic section? Comment 310: Line 2010: "ö", o. Comment 311: Line 2010: "NE-west", ? NE-SW? Comment 312: Line 2015: "ö", o. Comment 313: Line 2025: "basement fabrics", What do you mean with basement fabrics? I can't see them. Adriabukta Fm is not basement! Comment 314: Line 2026: "Adriabukta Formation", The Adriabukta Fm is really thick in this restoration: at least several kilometers!!! What is lying on top of the Adriabukta Fm towards the east outside this restoration? Comment 315: Figure 6d: Where is the large-scale folds and thrusts underneath the Wordiekammen Fm in the Mimerdalen area? In this restroation, they don't exist!! Comment 316: Figure 6e: You can cancel this: these little diagrams are just enlargments from the sections above and do not explain why the Ellesmerian deformation is eliminated. They also don't explain the interpreted de-coupeling of the structures in the Andrée Land Group and the overlying Billefjorden and younger groups. Comment 317: Figure 6 legend: I can't distinguish

Printer-friendly version

Discussion paper
Interactive comment

\section{Discussion paper}

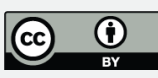


these patterns in the cross-sections. Comment 318: Line 2032: "erosion-related exhumation of basement rocks", How do you know that the basement underneath the Devonian west of the Balliolbreen Fault was exposed in the Devonian? Do you have any idea how thick the Devonian is west of the Balliolbreen Fault? In your diagram it wegdes out towards the Balliolbreen Fault. In contrast, a minimum thickness of $2.5 \mathrm{~km}$ can be roughly estimated for the Devonian west of the Balliobreen Fault from the attached Fig. 3. Comment 319: Line 2036: "early Cenozoic Eurekan contraction", .....and where is the assumed Cenozoic fold and thrusts in the Devonian ORS sandstone? Comment 320: Line 2041: "Iff", II Comment 321: Line 2041: "Triungen-Grønhorgdalen Fault Zone",What happens to the west of this fault? Comment 322: Figure 7: Was the Mariekammen Shear Zone active during the deposition of the Adriabukta Fm? How do you know that? Comment 323: Lines 2043-2044: "showing the development of a N-S- to NNW-SSE-trending metamorphic core complex in Hornsund", Please can you provide any geological and structural field evidence for this assumption? And does it mean the "core complex" was active from Early Devonian through lateb Mississippian?x Comment 324: Lines 2048-2049: "along newly formed extensional faults and shear zones within the Adriabukta Formation", How do you know this? Comment 325: Line 2049: "(b2)", I do not see much differences between B2a, B2b and B2c. Comment 326: Line 2049: "excisement-incisement processes", What is this?? Comment 327: Line 2050: "core complex-bounding detachment", Have you seen the core complexbounding detachment, or have you ever heard that someone has mapped and found such detachment? Comment 328: Lines 2054-2055: "(black arrows showing the onlaps and angle between bedding surfaces of the two formations)", This indicates that the orientation of the bedding planes in the different stratigraphic units should be different. I don't remember that anyone before has described this.

Author's reply Comment 1: agreed. Comment 2: agreed. The manuscript's discussion is also based on a large literature review including scientific articles, unpublished manuscripts and books in both English, Norwegian, French and German, many of which are not available online, especially literature in German about the Ellesmerian 
Orogeny (e.g., Piepjohn et al., 1997a; Michaelsen et al., 1997; Kempe et al., 1997; Michaelsen, 1998) and in French about potential extensional detachments in northern Spitsbergen (Roy, 2007, 2009; Roy et al., unpublished). The manuscript attempts to reconcile all observations made by teams with significantly different hypotheses, notably, Chorowicz (1992), Roy (2007, 2009), Roy et al. (unpublished), and Braathen et al. (2018a) on the one side (late-post Caledonian Devonian-Mississippian extensional collapse), and Piepjohn et al. (1997a), Michaelsen et al. (1997), Michaelsen (1998), Piepjohn (2000), and Bergh et al. (2011) on the other side (Ellesmerian Orogeny). Comment 3: partly disagreed. The author of the present manuscript has investigated outcrops in several localities in central Spitsbergen but hereby reports field observations in only one of them (Pyramiden). The author failed to replicate major outcomes from previous studies in a key locality (Pyramiden) for the late Paleozoic geology of Spitsbergen. Notably, the author finds no trace of a major fault like the Balliolbreen Fault at the investigated locality, which is mapped at this locality by previous authors (e.g., Harland et al., 1974). The author of the present manuscript attempted to cut several thin sections both in the footwall and in the hanging wall of the presumed Balliolbreen Fault. All of the sections from the hanging wall of the fault resulted in misleading thick-sections of quartz as shown in the supplements (quartz resembling pyroxenes). Since the thin sections in the fault's hanging wall consistently resulted into thick sections and since two petrologists (from the University of Troms $\varnothing$ ) initially misinterpreted quartz cristals on thick sections to represent pyroxene crystals on thin section, it is possible that the issue occurred to other research teams, thus leading to similar erroneous interpretations. The author also found out that uppermost Devonian-Mississippian sedimentary strata of the Billefjorden Group described as generally undeformed in this area turned out to be intensely deformed (figure $3 \mathrm{~b}$ in the manuscript). The author of the present manuscript also attempted to find satisfactory, indisputable evidence (e.g., field photograph of tightly folded Devonian strata truncated by a post-Devonian unconformity) supporting Ellesmerian contraction in the field and in available scientific literature without success. Thus, the present 
manuscript is also based on major reinterpretation of previously acquired field data and structural relationships at localities used to support Ellesmerian deformation in Spitsbergen. Importantly, the interpretation of outcrop photographs published in manuscripts such as Michaelsen (1998; her figure 53) are highly questionable and do not provide any satisfactory evidence to support Ellesmerian contraction. In her figure 53, Michaelsen (1998) infers the presence of a major Ellesmerian thrust, the upper Munindalen thrust, juxtaposing relatively young red sandstones of the Dicksonfjorden Member of the Wood Bay Formation in the hanging wall and relatively old green sandstones of the Austfjorden Member of the Wood Bay Formation in the footwall. The first uncertainty around the interpretation of such large outcrop photographs is whether Michaelsen and her co-workers actually directly observed a fresh outcrop portion showing the contact between sandstones of the Dicksonfjorden and Austfjorden members. If not, the interpretation of this photograph should be treated as an interpretation of a distant photograph of an outcrop mostly covered by screes and inaccessible. The second uncertainty is related to the basic geological concept of normal versus reverse fault: a fault that juxtaposes younger rock units in the hanging wall against (over) older rocks units in the footwall generally corresponds to a normal fault, i.e., definitely not a Ellesmerian thrust. Furthermore, the contact between the uppermost Carboniferous-lowermost Permian Wördiekammen Formation and underlying Devonian sedimentary strata of the André Land Group and Mimerdalen Subgroup is generally covered by screes and/or not accessible for detailed outcrop study. Thus, any interpretation related to the nature of the boundary by previous works such as Piepjohn (2000) and Bergh et al. (2011) should also be regarded as interpretation, not observations, and should therefore be considered with care. Comment 4: disagreed. The present manuscripts reaches a different conclusion than that of studies supporting the Ellesmerian Orogeny in Spitsbergen by using an interdisciplinary approach, a thorough structural (and microstructural) analysis of outcrops actually accessible by foot and showing well exposed bedrock, an extensive review of long-forgotten literature (e.g., Chorowicz, 1992; Roy, 2007), and on reinter- 
pretation of data and outcrop transects in central Spitsbergen. The outcrops described in the present manuscript are accessible and show well exposed bedrock, which contrast with regional outcrop transects mostly covered by screes and partly-mostly inaccessible used by Dr. Piepjohn to support Ellesmerian deformation in Spitsbergen (e.g., Michaelsen, 1998, her figure 53). What is inadequate is that, thus far, only one of the two major hypotheses about the Devonian-Mississippian tectonic history of Spitsbergen was tested further: that of the Ellesmerian Orogeny. One of the main reasons as to why the other hypothesis (late-post-orogenic extensional collapse) was, thus far, more or less disregarded (except in recent work by Braathen et al., 2018a, 2020) has certainly a lot to do with Prof. Chorowicz running out of financial support for his work in Svalbard (Chorowicz, pers. comm. 2019) and to the fact that most associated manuscripts were either written in French (Roy, 2007, 2009), either left unpublished (Roy et al., unpublished). The present manuscript attempts to re-establish a balance between these two competing hypotheses. Comment 5: disagreed. The present manuscript does not argue that "the base of the Billefjorden/Gipsdalen groups north of Isfjorden is a detachment instead of an unconformity" everywhere in central Spitsbergen. Instead, the present manuscript argues for the presence of local bedding-parallel décollements along stratigraphic boundaries (e.g., at the boundary between the Billefjorden Group and rocks of the Andrée Land Group and within coals and coaly shales of the Billefjorden Group in Pyramiden, in SassenfjordenTempelfjorden and Reindalspasset). Without the presence of the newly described bedding-parallel décollements and duplexes, the Pyramiden locality would support the occurrence of Ellesmerian deformation in Dickson Land. Now instead, the Pyramiden locality supports partial strain partitioning and decoupling during top-west Eurekan thrusting. Comment 6: the present manuscript refers to the work by Chorowicz (1992), Roy $(2007,2009)$ and Roy et al. (unpublished) in Andrée Land and James I Land. Notably, the work of Roy (2007) includes a 167-page appendix with 111 figures, among which at least 56 actual field photographs with interpretation supporting the presence of low-moderate-angle Devonian extensional detachments and normal 
faults in central Spitsbergen (e.g., Roy, 2007, his figure 23 in Kota). Comment 7: disagreed. The author of the present manuscript agrees that the question approached by the present manuscript (the occurrence or not of shallow-crustal to near-surface Ellesmerian deformation in Spitsbergen in the Late Devonian-earliest Mississippian) is "too important to be solved by the anaylsis of just one outcrop" (Dr. Piepjohn's comment 7). The present manuscript is not limited to "just one outcrop". The author of the present manuscript also interpreted many satellite images in Spitsbergen (not only one as mentioned by Dr. Piepjohn, but only one included in the present manuscript), many seismic sections in and around Spitsbergen (not only two; see seismic database used by the author of the present manuscript in Figure 26), analyzed thin sections of fault rocks and in Devonian-Mississippian sedimentary strata (some of which are shown in the supplements), reviewed (and, where appropriate, reinterpreted) many outcrop transects (see Figures 2-25 attached to the present discussion) used by Dr. Piepjohn to design his idealized sketches of Ellesmerian deformation (e.g., Piepjohn et al., 1997a, their figures 9-12 and 14; Piepjohn, 2000, his figures 4, 6-8, and 10), performed a thorough search and review of lengthy scientific literature about the geology of Svalbard in English, French (e.g., Roy, 2007), German (e.g., Piepjohn et al., 1997a; Kempe et al., 1997; Michaelsen et al., 1997; Dissmann and Grewing, 1997; Michaelsen, 1998) and Norwegian (e.g., Aakvik, 1981), and interacted with various experts who have published recent cutting-edge research results and discoveries about the geology of Svalbard and/or who are experts with the geology of Svalbard and the Arctic (e.g., Dr. Christopher Berry, Prof. John Marshall, Dr. Gilda Lopes, Prof. Gunn Mangerud, Dr. Winfried Dallmann, Prof. Steffen Bergh, Prof. Alvar Braathen, Prof. Per Terje Osmundsen, Assoc. Prof. Jaroslaw Majka, Prof. Jean Chorowicz, Prof. Benoit Beauchamp). Thanks to these thorough actions, the author of the present manuscript believes that discussion of whether Ellesmerian deformation occurred or not in Spitsbergen is possible in the present manuscript. The author of the present manuscript conceeds that the debate is just getting (re-) started and does not pretend that the model argued for in the present manuscript represents the ultimate truth.

Interactive comment
Printer-friendly version

Discussion paper 
Much work remains, as discussed at the end of the conclusion (lines 1338-1351). Comment 8: partly agreed. The present study shows a thorough investigation of well exposed bedrock in outcrops actually accessible by foot (by contrast with outcrop transects used by Dr. Piepjohn), whereas most outcrop localities with interpreted Ellesmerian structures are either not accessible for detailed structural investigation (e.g., unconformity between Wordielkammen Formation and Devonian rocks of the Andrée Land Group/Mimerdalen Subgroup in Munindalen is localed on inaccessible steep slopes and mostly-completely covered by screes) or are not documented with actual field photographs in the relevant literature - for example, Piepjohn et al. (1997a) and Michaelsen et al. (1997) show exclusively idealized conceptual sketches instead of actual field photographs. Knowing that large parts of the outcrops on which these sketches are based are mostly made up with loose material and/or not accessible (too steep slopes; Figures 2-25), one may wonder about the (most likely high) amount of interpretation involved in these sketches. The present manuscript is based on new field data, on observation of actual field photographs in Dickson Land, and on all the field data and field photographs published by previous workers such as Dr. Piepjohn and his co-workers. The present study uses an interdisciplinary approach based on field data, satellite images, seismic sections, exploration well data, and petrological and microstructural analysis of thin (and thick) sections as well as on an extensive and rigorous literature review. By contrast, Dr. Piepjohn and supporters of Ellesmerian contraction in Spitsbergen base their interpretation almost exclusively on field data or monodisciplinary datasets. The author of the present manuscript fails to understand in which way the approach used in the present manuscript is not valid. In the light of nowadays ethical standards for scientific research, the approach and method used by Dr. Piepjohn in his studies (over 20 years ago) are certainly less valid than those used in the present manuscript. Notably, Dr. Piepjohn's contributions do not include any description of the amount of uncertainty involved in his field observations and interpretations and do not to include any actual field photograph of key outcrop transects he used to argue for Ellesmerian deformation in Spitsbergen (e.g., Piepjohn

Printer-friendly version

Discussion paper
Interactive

comment

\section{C53}


et al., 1997a; Piepjohn, 2000). The present manuscript is based on a lot more than the analysis of "one outcrop", "one satellite image" and three seismic sections. However, the field data (from one outcrop locality), and the attached interpretations of one satellite image and of three seismic sections were deemed to be enough to illustrate the manuscript's discussion. Noteworthy, in his publications (e.g., Piepjohn et al., 1997a; Piepjohn, 2000), Dr. Piepjohn did not attach all the field photographs he took of all the outcrop localities he and his research team visited. He actually did not attach any at all and illustrated his manuscript's argumentation with idealized conceptual sketches. Again, one may wonder how much interpretation and uncertainty is involved in such sketches of outcrops partly-mostly consisting of loose material and whether these outcrops were indeed possible to access everywhere for detailed structural outcrop studies. In addition, the study presented in the present manuscript is not "restricted to an extremely small area" (only the field component of the study is restricted to a small part of Dickson Land). The study shows and discusses structures throughout central, northwestern, western and southern Spitsbergen. Comment 9: partly agreed. The present manuscript is not exclusively based on "hard data", and neither is Dr. Piepjohn's work in Spitsbergen, e.g., speculating about the nature of the boundary between the Wordiekammen Formation and Devonian rocks of the André Land Group/Mimerdalen Subgroup in outcrops partly-mostly covered by screes and/or inaccessible for detailed field mapping (because located on steep slope). However, the present manuscript actually uses multiple datasets and reinterpretation of data and photographs from previous studies, and combines these objectively before drawing conclusions. The author of the present manuscript fails to understand how outcrops like in Triungen (figure $3 \mathrm{c}$ in the manuscript) or Mimerdalen or Munindalen (Figures 2-25) may in any case represent "hard data" for Dr. Piepjohn. In Triungen, uppermost Devonian-Mississippian strata of the Billefjorden Group are described as completely undeformed, although the base of this succession is clearly covered by screes and, thus, not possible to observe. It is very much possible that, like in Pyramiden, the coal-rich (the presence of which is suggested by a predominance

Printer-friendly version

Discussion paper
Interactive

comment

\section{C54}


of black-colored screes) base of the Billefjorden Group may be strongly deformed and decoupled Cenozoic contraction. An episode of Ellesmerian contraction is therefore not needed to explain the deformation in Devonian rocks. In Mimerdalen and Munindalen, most outcrop transects interpreted by Dr. Piepjohn and his team and used to produce their schematic and idealized conceptual sketches are mostly to completely consisting of loose materal and show that the unconformity between Devonian rocks of the Andrée Land Group/Mimerdalen Subgroup and overlying strata of the Wordiekammen Formation is covered by screes and/or inaccessible for detailed outcrop study almost everywhere (Figure 2-14). Comment 10: disagreed. The present manuscript refers to publications supporting both Ellesmerian contraction (Harland et al., 1974; Lamar et al., 1986; McCann and Dallmann, 1996; Piepjohn et al., 1997a; Michaelsen et al., 1997; Michaelsen, 1998; Piepjohn, 2000; Bergh et al., 2011; Piepjohn and Dallmann, 2014; Dallmann and Piepjohn, accepted) and late-post Caledonian extensional collapse (Chorowicz, 1992; Roy, 2007, 2009; Roy et al., unpublished; Braathen et al., 2018, 2020), which is not the case of contribution supporting Ellesmerian deformation that only refer to work supporting Ellesmerian deformation (e.g., Piepjohn et al., 1997a; Kempe et al., 1997; Piepjohn, 2000). The fact that the present manuscript's conclusions do not agree with most published literature does not mean that the discussion is one-sided. The present manuscript's discussion aims at generating constructive scientific discussion and future studies about a topic that has, thus far, been one sided (i.e., discussion of Ellesmerian deformation but not of collapse-related extensional detachments). As mentioned in the reply to comment 4, most published work about Devonian-Mississippian tectonism aimed at testing the hypothesis of Ellesmerian contraction and do not consider/discuss the possibility that folds in Devonian sedimentary rocks might be related to extensional deformation (e.g., detachment folding). Fold structures formed in extensional setting are increasingly identified by scientific literature (Chauvet and Séranne, 1994; Osmundsen and Andersen, 1994; Fletcher and Bartley, 1994; Osmundsen et al., 1998; Krabbendam and Dewey, 1998; Fossen et al., 2013; Schwerdtner et al., 2016), and 
so is the need for interdisciplinary approaches as required by public bodies like the European Research Council (https://erc.europa.eu/news/supporting-interdisciplinaritychallenging-obligation). Interdisciplinary research was actually scientifically proven to benefit scientific productivity and impact in various scientific disciplines (Roper and Brookes, 1999; Steele and Stier, 2000; Omodei et al., 2016). Dr. Piepjohn argues that many publications are not considered but fails to mention which publications, and later acknowledges that he is "very impressed by the number of references and the work on the literature research" in his comment 12. Comment 11: agreed. However, the manuscript is discussing the occurrence of a whole tectonic event and therefore requires reference to many appropriate references. Comment 12: agreed. Comment 13: agreed. Comment 14: agreed. Neither does it happen very often that such a scientific problem is dealt with such one-sided approach (significantly more scientific contribution testing the hypothesis of Ellesmerian contraction compared to publications testing that of late-post Caledonian extensional collapse). Eurekan deformation was observed throughout the entire island of Spitsbergen, all the way to Hinlopenstredet, east of Spitsbergen, where Early Cretaceous dolerite are sheared in a sinistral fashion (Figure 27). Comment 15: agreed, and it is these controversial issues that the present manuscript is attempting to address. Referring to the issues around the age of Ellesmerian deformation, there is no unambiguous geochronological age dating of Ellesmerian structure in Devonian sedimentary strata. As highlighted in the discussion of the present manuscript, potential Ellesmerian (Late Devonian-Mississippian) ages were obtained for ductile deformation along shear zones and metamorphic events attached to shear zones (Kośmińska et al., 2017; Majka and Kośmińska, 1230 2017; Faehnrich et al., 2017; Schneider et al., 2018) showing normal kinematic indicators (Schneider et al., 2018, their figure 3b, e and f), and, therefore, are more likely to reflect core complex exhumation rather than contraction. Moreover, the study by Schneider et al. (2018) further illustrates the point of the present manuscript that geological research has, thus far, been one-sided in favor of the hypothesis of Ellesmerian deformation. If the hypothesis of Chorowicz (1992), (Roy, 2007,

Printer-friendly version

Discussion paper
Interactive

comment

\section{6}


2009) and Roy et al. (unpublished) had been further tested in more details and by more research teams, Schneider et al. (2018) might have considered discussing the implications of the geochronological ages they obtained for late-post-orogenic collapse processes. Comment 16: Again, Dr. Piepjohn suggests that only new extensive field data could possibly lead to a re-evaluation and questioning of the Ellesmerian Orogeny hypothesis and fails to see the need of an interdisciplinary approach. Outcrops in Svalbard have already been examined extensively and their implications discussed and exploited to support Ellesmerian deformation. However, field observations (generally made on outcrop transects that are discontinuous in 3D) had, thus far, not yet been confronted to other datasets such as seismic data. By contrast to field data, seismic data are continuous in one direction and provide a correlation tool not available when mapping outcrops that were subjected to extensive erosion, and/or that are partly-mostly covered by loose material, and/or that are inaccessible by foot for detailt outcrop study. Furthermore, there are scientific issues in Svalbard that field data may be able to resolve. One example is the presence of Timanian faults at depth in Svalbard as documented by aeromagnetic, seismic and seismological data onshore and offshore Svalbard (Klitzke et al., 2019; Koehl, 2019a, 2019b, 2020). In northern Spitsbergen, such faults are located at great depth and, therefore, not possible to observe in the field. In this particular case, only younger (Devonian and Eurekan) fault overprints crop out (Koehl, 2019a, 2020; Koehl et al., in prep. a). Comment 17: disagreed. The present manuscript does not argue for the presence of a regional detachment between Devonian rocks of the Andrée Land Group/Mimerdalen Subgroup and post-Devonian sedimentary rocks as suggested by Dr. Piepjohn and his figure 3. However, the present manuscript does discuss the presence of local detachments like the Keisarhjelmen Detachment (Braathen et al., 2018a) and the Woodfjorden Detachment (Roy et al., unpublished), the presence of a local detachment between green sandstones of the Austfjorden Member and overlying red sandstones of the Dicksonfjorden Member of the Wood Bay Formation instead and in place of the upper Munindalen thrust of Michaelsen (1998), and/or the

Interactive comment
Printer-friendly version

Discussion paper

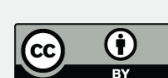


presence of a possible décollement between green sandstones of the Austfjorden Member of the Wood Bay Formation and the Wordiekammen Formation in this area since local décollements-detachments are known to exist along the lower stratigraphic boundary of the Wordiekammen Formation (McCann, 1993, his figure 5.6). The present manuscript does not deny the fact that, in most places in Svalbard, Devonian rocks of the Andrée Land Group/Mimerdalen Subgroup and post-Devonian rocks are separated by a stratigraphic unconformity. In addition, the present manuscript is not only based on "field observations restricted to a small outcrop at Pyramiden near the Balliolbreen Fault" (see replies to Dr. Piepjohn's comments 4, 7, 8 and 9). Comment 18: partly disagreed. The present manuscript's discussion is based on the presence of local décollements and "detachment at the base of the Billefjorden Group" and Wordiekammen Formation, particularly where thickened coal-rich sedimentary strata of the Billefjorden Group allowed decoupling. In addition, the discussion in the present manuscript is based on evidence (not assumption) for metamorphic core complex exhumation in northwestern Spitsbergen (Braathen et al., 2018a, 2020) and Isfjorden (Koehl, 2019a, 2019b, 2020). Thus, the present manuscript discusses the presence of additional core complexes (e.g., in southern Spitsbergen). In addition, the present manuscript is also based on additional items (e.g., exploration well data, reinterpretation of existing field data, analysis and reinterpretation of field photographs of large outcrop transects in Dickson Land) as already mentioned in replies to Dr. Piepjohn's comments 4, 7, 8 and 9. Comment 19: partly agreed. There are different opinions about the age of the Billefjorden Group. However, there is not much debate about this problem. According to Dr. Piepjohn, some samples in the uppermost part of the Plantekløfta Formation showed Late Famenian spores (Brinkmann, 1997, cited in Piepjohn and Dallmann, 2014). However, the Brinkmann (1997) publication, a Master's Thesis (written in German) upon which Dr. Piepjohn's claim is based is not available online or, e.g., at the Norwegian Polar Institute library. In addition, Piepjohn et al. (2000) claim the presence of (late Famennian) Retispora lepidophyta microspore within the uppermost part of the Plantekløfta Formation without providing any picture 
of the observed specimen (actually provided in Schweitzer, 1999), which makes their claim difficult to assess. Based on these, however, Dr. Piepjohn argued that Famennian fossils and spores from the lower part of the Billefjorden Group (e.g., Lindemann et al., 2013) reflect reworked specimens from the Plantekløfta Formation (Piepjohn and Dallmann, 2014). Dr. Lindemann (paleontologist; Natural History Museum in Oslo) Prof. Volohonsky (paleontologist; University of Tübingen, Germany) and Prof Marshall (palynologist; University of Southampton and chair of the Subcommission on Devonian Stratigraphy) suggested a Famennian age for the base of the Billefjorden Group in Triungen based on spores and fish and tetrapod remains (Lindemann et al., 2013; Marshall et al., 2015). More recently, Dr. Berry (paleobotanist, University of Cardiff) and Prof. Marshall (palynologist; University of Southampton) reevaluated the age of the Plantekløfta Formation to be early Frasnian based on fossils and miospores (Berry and Marchall, 2015; see also their supplements). In addition, the paleontological study of Newman et al. (2019; Dr. Newman is a paleontologist, Dr. Carole Burrow is a paleontologist at the Queensland Museum, and Prof Jan L. den Blaauwen is a paleontologist at the University of Amsterdam) recently evidenced the presence of an articulated acanthodian in the Fiskekløfta Formation, i.e., most likely unreworked fossil, suggesting a Givetian (Middle Devonian) age for this stratigraphic unit rather than late Famennian. Dr. Scheibner (sedimentologist; Bremen University), Dr. Hartkopf-Fröder (paleontologist; Geological Survey North Rhine-Westphalia), Dr. Dierk Blomeier (sedimentologist; Norwegian Polar Institute) and Prof. Holger Forke (paleontologist; Humbolt University of Berlin) also inferred a Famennian age for the lower part of the Billefjorden Group in Lomfjorden based on miospore assemblages (Scheibner et al., 2012). Dr. Gilda Lopes (palynologist) has, as well, inferred a middle Famennian age for the base of the Billefjorden Group in Svalbard based on microspore assemblages (Lopes, pers. comm. 2019). Furthermore, the lowermost part of the Billefjorden Group on Bjørnøya is also Famennian in age based on palynological studies (see references in Dallmann et al., 1999). Dr. Piepjohn (who is a structural geologist/tectonicist) and his team (the actual palynological work was actually done

Interactive comment
Printer-friendly version

Discussion paper

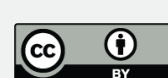


by a graduate student with limited experience) are the only one to argue for a late Famennian age for the Plantekløfta Formation (Piepjohn et al., 2000), whereas at least four teams of paleontologists-palynologists-paleobotanists (Dr. Berry's team, Dr. Newman's team, Dr. Lopes's team, and Dr. Scheibner's team) all contradict the results of Piepjohn et al. (2000) through more recent studies, and consistently found Famennian ages for the base of the Billefjorden Group and Givetian-early Frasnian ages for the Plantekløfta Formation throughout Svalbard (Scheibner et al., 2012; Lindeman et al., 2013; Berry and Marshall, 2015; Marshall et al., 2015; Newman et al., 2019; Lopes, pers. comm. 2019), including clear proofs of non-reworking (Newman et al., 2019). Again, Dr. Piepjohn and his team base their age estimations on the presence of Retispora lepidophyta microspore (making up $<1 \%$ of the spore assemblages, by which they actually mean one sample of Retispora lepidophyta) within the uppermost part of the Plantekløfta Formation without providing any pictures of the observed specimen, thus making their argument rather weak compared to that of other research teams. Dr. Piepjohn further argues (in Piepjohn and Dallmann, 2014) that "due to the occurrence of Late Famennian spores in the uppermost Plantekløfta Formation [again referring to Piepjohn et al. (2000)] [he is] inclined to consider the Famennian specimens [of Lindemann et al. (2013)] as reworked", which is no more than speculation based on the misidentification of (Famennian) Retispora lepidophyta by Piepjohn et al. (2000; see Berry and Marshall, 2015, their supplement DR3). Most importantly, Dr. Berry and Prof Marshall recently discussed the only specimen of Retispora lepidophyta upon which Dr. Piepjohn's age estimation is based (Berry and Marshall, 2015, their supplement DR 3). The specimen is shown in Schweitzer (1999, his plate 6 figure 10 and plate 7 figure 1) and, according to both Dr. Berry (who is a paleobotanist) and Prof. Marshall (who is a palynologist), is a clear misidentification for multiple reasons. Among others, the specimen shows different size and different holes than actual Retispora lepidophyta (Berry and Marshall, 2015, their supplement DR 3; Marshall, pers. comm. 2020). Therefore, the author of the present manuscript does not believe that there is much debate around the actual age of the Billefjorden 
Group and Plantekløfta Formation, and further argues that adding the arguments presented herein to the discussion would only lengthen an already long manuscript (see Dr. Piepjohn's comment 11). Noteworthy, Prof. Hartkopf-Fröder (paleontologist; University Geological Survey North Rhine-Westphalia) has attempted to locate the samples analyzed by Dr. Piepjohn and his student, unfortunately without success (Marshall, pers comm. 2020). Regarding the Okse Bay Formation on Ellesmere Island mentioned by Dr. Piepjohn in his comment, the Formation was reinterpreted to be Serpukhovian in age (and is now included as part of the Borup Fiord Formation), which is different from the Billefjorden Group in Svalbard (Beauchamp et al., 2018). Comment 20: disagreed. Since there is not space left for doubt regarding the age of the base of the Billefjorden Group and of the Plantekløfta Formation (see reply to Dr. Piepjohn's comment 19), the author of the present manuscript feels that the use of descriptive adjectives such as "uppermost Devonian-Mississippian" is more appropriate and is actually relevant to discuss changes in the tectonic history of Spitsbergen proposed in the present manuscript. Noteworthy, the "confusing time segments" Dr. Piepjohn is referring to are official standards from the International Chronostratigraphic Chart 2018. Comment 21: agreed. The present manuscript already refers to the accepted lithostratigraphy Dr. Piepjohn mentions in his comment (e.g., Fiskekløfta, Planteryggen and Plantekløfta formations). However, the present manuscript does not include reference to the accepted "Mimerdalen Subgroup". Comment 22: disagreed. The term "Orogeny" commonly refers to episodes of contraction lasting for several tens of million years. Thus, the author of the present manuscript considers that the timing and time span, which are constrained by recent paleontological and palynological studies (Scheibner et al., 2012; Lindeman et al., 2013; Berry and Marshall, 2015; Marshall et al., 2015; Lopes et al., 2018a; Newman et al., 2019; Lopes, pers. comm. 2019), are paramount. In the present case, time constraint on Devonian sedimentary rocks of the Mimerdalen Subgroup believed by Dr. Piepjohn to be pre-Ellesmerian (late-latest Givetian Fiskekløfta Formation) and to represent the onset of Ellesmerian contraction in Svalbard (ca. 380 Ma, i.e., early Frasnian Planteryggen and Plantekløfta

Printer-friendly version

Discussion paper
Interactive

comment 
formations; Berry and Marshall, 2015) suggest that the Ellesmerian Orogeny most likely lasted ca. 3 million years (383-380 Ma), which makes its occurrence in Spitsbergen doubtful. Comment 23: disagreed. The contact at "the small described outcrop at the Balliolbreen Fault near the entrance of the Pyramiden coal mine" is actually relatively well exposed (although poorly exposed) compared to most areas studied (from the distance) by Dr. Piepjohn and his team either in inaccessible steep slopes and/or covered by screes (Figures 2-25). As mentioned by Dr. Piepjohn (his comment 12), the present manuscript contains an incredible amount of references (most of which are not accessible online and/or not in English, and, therefore, inaccessible to most researchers). The author of the present manuscript bases his interpretation on careful review of all field data from Dr. Piepjohn's publications resulting from his field campaigns in Spitsbergen and of field photographs of outcrop transects used by Dr. Piepjohn and his team to infer Ellesmerian deformation (Figures 2-25). So yes, the author of the present manuscript has, indeed, "paid attention to [and] has seen and investigated this contact [i.e., between rocks of the Andrée Land Group/Mimerdalen Subgroup and overlying rocks of the Billefjorden and Gipsdalen groups] in the areas in central Dickson Land west of the Balliolbreen Fault". In addition, the author of the present manuscript benefited from field photographs in James I Land published in Roy (2007) showing moderately dipping Devonian normal faults/detachments potentially explaining the tilting (and folding) of Devonian rocks of the Andrée Land Group/Mimerdalen Subgroup there. The manuscript does not argue that the contact between rocks of the Andrée Land Group/Mimerdalen Subgroup and Billefjorden Group is poorly exposed everywhere, but that it was overinterpreted and/or wrongly interpreted (as a stratigraphic unconformity although not clearly exposed) in a few critical places such as Triungen and Pyramiden. The present manuscript shows that such overinterpretation of unexposed sections (see Figures 2-25) may provide what Dr. Piepjohn qualifies as proof "that the Svalbardian deformation event has taken place without a doubt" (his comment 15) and, thus, result in interpreting the occurrence of an orogenic event in areas where it is not needed to explain deformation patterns

Printer-friendly version

Discussion paper
Interactive

comment

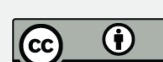


in local sedimentary rocks. Furthermore, Dr. Piepjohn argues that the model and observations discussed in the present manuscript suggest that "the entire base of the Billefjorden/Gipsdalen groups between the BFZ and the WSFTB in the west might be a huge, regional detachment". This is not what is argued for in the present manuscript, which instead argues for the presence of such structures in a few localized areas such as Pyramiden and Triungen. As pointed out by Dr. Piepjohn in his publications (and those of his research team), Ellesmerian deformation is preserved only in a few areas/belts in Svalbard, including Dickson Land (Piepjohn, 2000), Andrée Land (Dallmann and Piepjohn, submitted), and Blomstrandhalvøya (Buggisch et al., 1994), which is curious and calls for caution. Regardless, in order to investigate Ellesmerian contraction, one need to focus only on the nature of the contact in a few places at these few localities (not everywhere in Spitsbergen). The author of the present manuscript does not feel that he needs more than the data he presented in the present manuscript and all the data already published, e.g., by Dr. Piepjohn and his team (thousands of measurements also supporting the conclusions of the present manuscript), but also by other research teams (Bergh et al., 2011) to support his conclusions (see also reply to Dr. Piepjohn's comment 288). Eurekan deformation has indeed affected Andrée Land as shown by folded Mississippian dykes in Krosspynten (Evdokimov et al., 2006; monchiquite dykes of Gayer et al., 1966). The conclusions of the present manucript are based on combined field and seismic observations and interpretations from the present study and from all previous studies available/accessible to the author of the present manuscript into a single model. Comment 24: partly agreed. The presence of detachments in Pennsylvanian and Permian evaporites is well documented, but these are not the main structures transferring deformation from the West Spitsbergen Fold-and-Thrust Belt to the Billefjorden Fault Zone and Lomfjorden Fault Zone. These are most likely connected by deep, NW-SE- to WNW-ESE-striking Timanian shear zones, e.g., Kongsfjorden-Cowanodden fault zone (Koehl, 2019a, 2020), that were reactivated-overprinted several times in the Phanerozoic (during Caledonian contraction, Devonian-Mississippian extension, and early Cenozoic Eurekan 
transpression-contraction) and accommodated kilometer-scale sinistral oblique-slip movement. Dr. Piepjohn also seems to suggest that if a structure has not been described "in any existing geological map or stratigraphic, sedimentological or structural publication", then it is therefore unlikely to exist. The author of the present manuscript wants to draw the attention of Dr. Piepjohn towards newly identified Timanian faults in the northern Barents Sea (Klitzke et al., 2019) and throughout Svalbard (Koehl, 2019a, 2020) that suggest that parts of the geology of Arctic regions (and Svalbard) are yet to be understood. In addition, Dr. Piepjohn's approach is solely based on field data (monodisciplinary), whereas the present manuscript uses satellite images, seismic, exploration well and field data and restoration of structural cross-sections (interdisciplinary). Furthermore, Dr. Piepjohn seems to imply that the contact between Devonian sedimentary rocks of the Andrée Land Group/Mimerdalen Subgroup and uppermost Devonian-Mississippian rocks of the Billefjorden Group (and uppermost Pennsylvanian-lowermost Permian strata of the Wordiekammen Formation) crops out and is known for certain to be "a sedimentary contact and unconformity" absolutely everywhere in Spitsbergen, which is not the case because it is mostly covered by screes, e.g., in Triungen, Mimerdalen, and Munindalen (Figures 2-25). Again, the present manuscript does not argue for "a large-scale detachment at the base of the post-Devonian sedimentary succession (base of Billefjorden/Gipsdalen groups)" as suggested by Dr. Piepjohn, but for the presence of local detachments-décollements that partitioned and decoupled strain during Eurekan deformation (e.g., in Pyramiden and Sassenfjorden-Tempelfjorden; see figures $3 b$ and 4 in present manuscript). Comment 25: disagreed. On the one hand, the fold structures in Liefdefjorden were reinterpreted by Braathen et al. (2018a, 2020) as extensional folds related to a crustal-scale Devonian extensional detachment (Keisarhjelmen Detachment). On the other hand, fold structures in Dickson Land and Andrée Land are difficult to date since uppermost Devonian-Mississippian strata of the Billefjorden Group were eroded throughout most of these areas, or because the contact between Devonian and uppermost Devonian-Mississippian strata is poorly exposed (covered by screes of the 
Billefjorden Group in Triungen and of the Wordiekammen Formation in Dickson Land), or because the contact is not accessible (only possible to observe from the distance, the danger of which is pointed out in the present manuscript and in the present discussion by showing the presence of mesoscale structures such as décollements requiring researchers to actually step onto the outcrops to observed them). The present manuscript provides direct outcrop observations (not observations and interpretation of distant, poorly exposed and inaccessible outcrops like Dr. Piepjohn's studies) of deformation pattern within Billefjorden Group sedimentary rocks just above/adjacent to Devonian rocks of the Old Red Sandstone in Pyramiden, one of key localities in Dickson Land where folded Devonian rocks of the Andrée Land Group/Mimerdalen Subgroup are juxtaposed against uppermost Devonian-Mississippian strata (the latter of which were assumed to be undeformed, though partly-mostly covered by screes, by Dr. Piepjohn and supporters of shallow-crustal Ellesmerian deformation in Spitsbergen) and upon which conceptual models of Ellesmerian deformation in Spitsbergen are based. Detailed studies of the outcrops in Pyramiden reveal intense shearing in uppermost Devonian-Mississippian coals and coaly shales, and, thus, the presence of Cenozoic décollements within the Billefjorden Group, which could explain differential deformation patterns within Devonian and post-Middle Devonian rocks throughout Spitsbergen in a much easier way than by adding a full episode of deformation right in the middle of a period of regional extension/subsidence (Devonian collapse, Carboniferous rifting, Permian-Triassic subsidence). The suggestion of Dr. Piepjohn that the author of the present manuscript "should really compare the small-scale tectonic structures he has described in the manuscript in one single outcrop at Pyramiden with the kilometer-scale fold structures and thrusts in Dickson Land [...] and in Andrée Land and in the Liefdefjorden area" is irrelevant because strain partitioning is about producing structures of different scale, kinematics and geometries in various areas and decoupling is about deformation producing similar structural contrasts between various stratigraphic units. Thus, although most likely formed synchronously in the early Cenozoic, fold structures in Devonian rocks in

\section{C65}

Printer-friendly version

Discussion paper
Interactive

comment 
Dickson Land and mesoscale structures in uppermost Devonian-Mississippian coals and coaly shales of the Billefjorden Group in Pyramiden are not comparable in size and geometries. Another important point that the model of Ellesmerian deformation does not address is mentioned by Dr. Piepjohn himself in the present comment: "all structures (except for Soerkapp Land - and this question is still unsolved) are characterized by tectonic transports to the west (Fig. 2), indicated by west-vergent folds, west-directed thrusts and by a formation of an intense fracture cleavage". One of Dr. Piepjohn's main argument to distinguish/segregate folds in Devonian rocks in Dickson Land and northwestern Spitsbergen from Cenozoic folds from the West Spitsbergen Fold-and-Thrust Belt is their vergence to the west, whereas Cenozoic folds (and, mysteriously, Ellesmerian folds as well) in western and southern Spitsbergen are east-verging (the same argument was used in Blomstrandhalvøya by Thiedig and Manby, 1992 and Kempe et al., 1997). However, new evidence from aeromagnetic and seismic data in Svalbard show the presence of a large, crustal-scale, NNE-dipping Timanian fault extending from Kongsfjorden to southern Edgeøya (Koehl, 2019a, 2020). An example is the NNE-dipping fault in figure $4 a$ and $b$ in present manuscript, which corresponds to a (Devonian-Carboniferous? and) early Cenozoic overprinting of the Kongsjorden-Cowanodden fault zone mentioned in Koehl (2019a, 2020). This fault is responsible for several kilometer to tens of kilometer left-lateral reverse displacement in the early Cenozoic and actually partitioned deformation between northern and southern Spitsbergen, thus explaining the contrast between west-verging Cenozoic folds in Devonian rocks in Dickson Land (north of the Kongsfjorden-Cowanodden fault zone) and east-verging Cenozoic folds in southern and western Spitsbergen. This argument further illustrates the need for more interdisciplinary approaches, instead of the more traditional monodisciplinary approach used by Dr. Piepjohn and his team. Moreover, the present manuscript also points out that the discriminating factors used by previous studies (e.g., Dallmann, 1992; Piepjohn, 1994; Bergh et al., 2011) to distinguish presumed Ellesmerian folds from Eurekan folds in southern Spitsbergen, including geometrical differences and the age of the stratigraphic units they affect, are

Interactive comment
Printer-friendly version

Discussion paper 
inappropriate since strain partitioning and decoupling occurred throughout Spitsbergen during Eurekan deformation (Maher et al., 1997; Braathen et al., 1999a, 1999b; Bergh et al., 2000; Leever et al., 2011a, 2011b; present manuscript; Koehl et al., in prep. a; see also Figure 28 from Koehl et al., in prep. a) and, thus, may be the cause of these inter-units geometry differences. Furthermore, the present manuscript shows that the trends and plunges of Eurekan and Ellesmerian folds reported by previous studies in southern, northern and central Spitsbergen are all very similar and, therefore, do not support that fold structures within Devonian rocks of the Andrée Land Group/Mimerdalen Subgroup formed during a different tectonic episode than Eurekan folds in post-Devonian rocks. Comment 26: agreed. This issue is addressed in a manuscript the author of the present manuscript is currently writing. The manuscript addresses and reconciles the opposite vergence of Cenozoic folds in northern (west-verging) and southern and western Spitsbergen (east-verging; see reply to comment 25). Extracts from this ongoing work are freely available on researchgate (e.g., https://www.researchgate.net/publication/335833913_Impact_of_Timanian_thrusts_on_the_Phanerozoic_tectonic_history and https://www.researchgate.net/publication/336799964_WNW-ESEstriking_Timanian_faults_in_Svalbard) and were presented at this year's EGU General Assembly as a Keynote presentation (https://meetingorganizer.copernicus.org/EGU2020/EGU2020-2170.html; which also includes presentation material). Again, the author of the present manuscript argues that the model presented in the present manuscript and in the above mentioned (soon to be submitted) work reconcile all the observations made by Dr. Piepjohn and his team better than a poorly constrained episode of Ellesmerian deformation. Comment 27: disagreed. Dr. Piepjohn's comment suggests than both Eurekan and Ellesmerian deformations can be observed "along the entire west coast of Spitsbergen and in entire NW-Spitsbergen", whereas, actually, Ellesmerian deformation in NW Spitsbergen can only be observed in Blomstrandhalvøya (small peninsula in western Spitsbergen). Again, Dr. Piepjohn is referred to the reply to his comment 24 describing the probable cause of the observed opposite vergence for Cenozoic folds in northern

Printer-friendly version

Discussion paper
Interactive

comment 
and southern/western Spitsbergen. Comment 28: disagreed. The relative age control mentioned by Dr. Piepjohn is discussed in the present manuscript and rejected because of the extremely poor quality of the large outcrop transects used by Dr. Piepjohn in his evaluation of relative timing (Figures 2-25). The only potential fault possibly representing a suitable candidate to date Ellesmerian contraction is the upper Munindalen thrust (Michaelsen et al., 1997; Piepjohn et al., 1997a). However, as discussed in the present manuscript, this fault is either a Devonian normal fault/extensional detachment which juxtaposes relatively old green sandstones of the lower member of the Wood Bay Formation (Austfjorden Member) in the footwall against younger red sandstones of the upper/middle member of the Wood Bay Formation (Dickonfjorden Member), either a stratigraphic unconformity (since the fault/unconformity is completely covered by screes, the issue as to whether this stratigraphic unit boundary is a normal fault/extensional detachment or an unconformity remains opened for speculation). Regarding the lower Munindalen thrust, this fault is either not covered by younger strata (because eroded) or involves uppermost Devonian-Mississippian strata of the Billefjorden Group and uppermost Pennsylvanian-lowermost Permian strata of the Wordiekammen Formation (e.g., in Robertsonbreen; Dissmann and Grewing, 1997, who were part of one Dr. Piepjohn's field campaign; Piepjohn, 1997a). Regarding fold structures in Devonian rocks of the Wood Bay Formation and Mimerdalen Subgroup, it is possible that they are in (most) places truncated by latest Devonian-earliest Permian stratigraphic unconformities as claimed by Dr. Piepjohn, but these folds are most likely the results of large-scale extension as suggested by previous (Chorowicz, 1992; Roy, 2007, 2009; Roy et al., unpublished) and ongoing work (Braathen et al., 2018a, 2020). Notably, Chorowicz (1992), Roy (2007, 2009), Roy et al. (unpublished) and Braathen et al. (2020) mapped erosional truncation of extension-related folds within Lower-Middle Devonian sedimentary rocks in Andrée Land and Raudfjorden, thus supporting that extension-related folding occurred in the Early-Middle Devonian and, thus, may as well have occurred in the Late Devonian. Later on, these folds may have been reworked during early Cenozoic deformation,

Printer-friendly version

Discussion paper
Interactive comment 
partially overprinting them (at least in places). Comment 29: disagreed. Again, the present manuscript does not argue for the presence of a single extensional detachment between Devonian rocks of the Andrée Land Group/Mimerdalen Subgroup and uppermost Devonian-Mississippian (-Permian) rocks throughout northern Spitsbergen, but rather for several localized Devonian extensional detachments like the Keisarhjelmen Detachment (Braathen et al., 2018, 2020) and the Woodfjorden Detachment (Roy et al., unpublished) and for localized Cenozoic décollements and duplexes and thrusts, e.g., in Pyramiden (figure $3 \mathrm{~b}$ in the present manuscript), Triungen (i.e., areas with thick layers of weak uppermost Devonian-Mississippian coals), southern Billefjorden (Figure 28 from Koehl et al., in prep. a), Birger Johnsonfjellet (McCann, 1993, his figure 5.6), Sassenfjorden-Tempelfjorden and Reindalspasset (figure 4 in the present manuscript). Comment 30: disagreed. Once again, Dr. Piepjohn refers to a map he drew (i.e., involving uncertainty because the bedrock is commonly covered by screes or commonly consists of loose material in most areas in Dickson Land) instead of showing hard evidences like an outcrop photograph (not viewed from a great distance) of the mentioned contact. Again, this contact was mostly investigated (interpreted) from great distance by Dr. Piepjohn and his team (e.g., Figures 2-25) and does not represent a convincing enough evidence in the light of how mesoscale structures may affect the tectonics of a whole region (e.g., mesoscale Cenozoic thrusts, décollements and duplexes in uppermost Devonian-Mississippian rocks of the Billefjorden Group in Pyramiden and Sassenfjorden-Tempelfjorden). In addition, Dr. Piepjohn is, once again, disregarding the observations (of members of his own team) that do not fit his model (involvement of both Devonian rocks of the Mimerdalen Subgroup and uppermost Devonian-Permian rocks of the Billefjorden and Gipsdalen groups in thrusting along the northern continuation of the lower Munindalen thrust in Robertsonbreen; Dissmann and Grewing, 1997). Comment 31: disagreed. Dr. Piepjohn argues that the existence of a core complex-related detachment is northwestern Spitsbergen is improbable on the basis that the geology of the area is "more complex" and that "the documentation and description of the presented data 
is not convincing,", but without providing further evidence to support his claim, only the fact that it is based on "6 or 7 field seasons". This high number of field mapping seasons in Spitsbergen, though honorable, does not in itself constitute an argument supporting shallow-crustal Ellesmerian deformation in Spitsbergen. The number of field seasons spent by a researcher acquiring data to test an erroneous hypothesis does not make the tested erroneous hypothesis more true. The present manuscript clearly demonstrate why Braathen et al. (2018a, 2020)'s model is more robust and better fit observations throughout northern Spitsbergen than Dr. Piepjohn's model of Ellesmerian deformation. Dr. Piepjohn's claim that the samples used for age determinations by Braathen et al. (2018a) are wrongly located is difficult to assess. Braathen et al. (2018a) tested a model of core complex exhumation that is unrelated to Ellesmerian contraction. Moreover, the journal in which the publication was submitted only allows limited amounts of information to be published (4 pages). Thus, reference to Ellesmerian contraction in Braathen et al. (2018a) was most likely not necessary, and non-reference of Dr. Piepjohn's Ph.D. work (by the way not available online) does not constitute in itself an argument to reject Braathen et al. (2018a)'s model. Dr. Piepjohn mentions that the "sedimentary contacts of the Devonian on top of the brecciated, weathered and karstified basement marbles is ignored" but fails to specify why it is important to discuss this contact. Shall the arguments of Dr. Piepjohn to distinguish between Ellesmerian and Eurekan structures in northwestern Spitsbergen be the same as used by Thiedig and Manby (1992), Buggisch et al. (1994) and Kempe et al. (1997) in Blomstrandhalvøya, the present manuscript already addresses the issue and rejects the arguments presumably supporting Ellesmerian deformation in Blomstrandhalvøya. Dr. Piepjohn further fails to mention why "the relation of ductile shear zones within the pre-Devonian basement rocks to the structures within the overlying Devonian rocks" should have been discussed in more details by Braathen et al. (2018a). Regardless, the publication of Prof. Braathen was subjected to a peer-review process after which it was accepted for publication, and it is not the purpose of the present manuscript and present discussion to comment/discuss this process. On 
a personnal note, I, myself, published three peer-reviewed scientific articles related to my (interdisciplinary) Ph.D. thesis in northern Norway (2018), two of which I am unfortunately already convinced are partly wrong, and, although both based on an interdisciplinary approach, involved data from an area too narrow (200 km x $300 \mathrm{~km}$ ) to provide a model that was robust enough to resolve the tectonic history of the area investigated. Realizing the weaknesses of my models came from a very long journey investigating related scientific issues in other parts of the world (Greenland, Canada, Svalbard) and, mostly, through the use of multiple interdisciplinary datasets. Thus, Dr. Piepjohn might need to consider that his own Ph.D. work (Piepjohn, 1994) might, perhaps, also need updates and revisions (e.g., in the light of recent advances in the acquisition of field data), especially since his (monodisciplinary) work is already a few decades (26 years) old and only based on observations in relatively narrow areas (total of $100 \mathrm{~km} \times 100 \mathrm{~km}$ for Ellesmerian belts in Spitsbergen). Comment 32: disagreed. The author simply mentions that the core-complex hypothesis was not tested in areas like Adriabukta and would (after the necessary restoration has been carried out; present manuscript's figures 5 and 7) actually explain deformation patterns within Devonian-Carboniferous rocks much easier than poorly documented and doubtful Ellesmerian deformation. The present manuscript presents a review of evidences in favor Ellesmerian deformation in all known locations where such structures were interpreted and, quite simply, provides an easier and more robust alternative than the Ellesmerian Orogeny to explain the observed structures. In addition, the author of the present manuscript uses knowledge from published literature (Bergh et al., 1997; Blinova et al., 2013) suggesting that the Bockfjorden Anticline metamorphic core complex continues southwards in Isfjorden (see also Koehl, 2020, pp. 53-64) and, possibly, farther south (Koehl, 2020, pp. 120-129). Comment 33: partly agreed. Though top-north movements along the Keisarhjelmen Detachment $\mathrm{n}$ northwestern Spitsbergen are possible, the amount of Devonian northward movement is a matter of debate, which was addressed by Dallmann and Piepjohn (2018) in their comment to the work by Braathen et al. (2018a; see also reply to Dr. Piepjohn's comment 262).

Printer-friendly version

Discussion paper
Interactive comment

\section{Discusion paper}

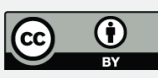


Nevertheless, the structures related to E-W contraction mentioned by Dr. Piepjohn in northwestern Spitsbergen could easily be Cenozoic in age since post-Devonian rocks are essentially absent in this area. What could actually be "very dangerous" for the Devonian tectonic history of Spitsbergen is that only one hypothesis should be tested (Ellesmerian deformation), while the others (e.g., Devonian extensional collapse and extension-related folding) are left untested and forgotten. Comment 34: agreed. However, the present manuscript does not aim at rediscussing what was already discussed in Braathen et al. (2018a) and further comments by Dallmann and Piepjohn (2018). Another good practive in science is to refer to work that one has actually had access to and read. The author of the present manuscript wants to draw the attention of Dr. Piepjohn and every scientist in every discipline to the importance of making one's own research available (in Diamond or Gold) Open Access Journals or at online repositories, and accessible (English language) to other scientists around the world. Not only the work referred to by Dr. Piepjohn is not available online, but a lot of it is actually written in German, which is not so easy to use by other researchers not familiar with the language. The present manuscript does discuss arguments for core complex exhumation in Spitsbergen and for Ellesmerian contraction but rejects every argument in favor of shallow-crustal to near-surface Ellesmerian deformation in the various areas of Spitsbergen, explaining why core complex exhumation is a much more realistic model than a short-lived episode of contraction or transpression (sections 5.2, 5.3 and 5.4 of the discussion in the present manuscript). Comment 35: agreed. The author of the present manuscript does take a firm stand and argues that, based on the many inconsistencies in the Ellesmerian Orogeny model (e.g., erroneous palynological ages in Piepjohn et al. 2000, very short timing of ca. 3 Myr, no significant difference between Ellesmerian and Cenozoic folds in southern and northern Spitsbergen in, e.g., Piepjohn, 2000 and Bergh et al., 2011, reinterpreted kinematics of presumed Ellesmerian shear zones in Prins Karls Forland and Hornsund actually exhibiting normal sense of shear, and many other issues listed and discussed in the discussion sections $5.2,5.3$ and 5.4 of the present manuscript), a core-complex model coupled

Interactive comment
Printer-friendly version

Discussion paper

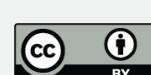


with Eurekan strain partitioning and decoupling is more likely. Regarding Braathen et al. (2018a), Prof. Braathen and his co-authors did indeed justify their preference for the core-complex model in their reply (Braathen et al., 2018b) to Dr. Piepjohn and Dr. Dallmann's comments (Dallmann and Piepjohn, 2018). Comment 36: disagreed. The present manuscript clearly shows that the interpretation of fold structures within Devonian rocks of the Adriabukta Formation in Adriabukta by Bergh et al. (2011) is based on nothing more than speculation, especially considering the incredible similarity of the pattern and geometries of these speculated Ellesmerian fold structures with Eurekan fold structures in adjacent and overlying Carboniferous rocks (Bergh et al., 2011, their figures $8 \mathrm{~b}$ and 9a), which do not show any significant differences. Thus, since Ellesmerian structures in southern Spitsbergen are no more than speculation, the present paper discusses another potential cause for the observed deformation in Adriabukta. The fact that Dr. Piepjohn spent three days testing an erroneous hypothesis acquiring data that do not even corroborate his claims does not change the fact that after a simple restoration of the Adriabukta section (present manuscript's figures 5 and 7) and prior to Eurekan contraction-transpression and careful reexamination of field observations by Birkenmajer (1964; folded Cretaceous dyke within the Adriabukta Formation), the hypothesis of Ellesmerian contraction in Hornsund cannot explain the observed deformation as well as core complex exhumation and subsequent strain partitioning and decoupling during Eurekan deformation. Furthermore, the author of the present manucript draws, once again, the attention of Dr. Piepjohn to ongoing work regarding the continuation of the Bockfjorden Anticline core complex southwards in Isfjorden (Koehl, 2019a, 2020; available on researchgate at https://www.researchgate.net/publication/335833913_Impact_of_Timanian_thrusts_on_the_Phanerozoic_tectonic_history thus suggesting that core-complex exhumation in Spitsbergen is not an isolated but rather a regional phenomenon. In his comment and explanation, Dr. Piepjohn still uses a very old-fashioned classification into "F1" and "F2" fold structures, which scientists are actually cautioned against (e.g., Fossen, 2020). It is now well understood that seemingly different structures may have formed synchronously instead

Interactive comment
Printer-friendly version

Discussion paper 
of during multiple tectonic episodes. Regardless, Dr. Piepjohn does not seem to have understood the crucial importance of restoring the Adriabukta section prior to Eurekan deformation to better understand Ellesmerian contraction in Hornsund. Such a simple restoration clearly shows that there are quite a few aspects of the geology of Hornsund that cannot realistically be explained by Ellesmerian deformation, among which the normal sense of shear of the Mariekammen Shear Zone, whereas Devonian core complex exhumation and subsequent strain decoupling and partitioning during Eurekan deformation may, indeed, reconcile the highly deformed (weak) shales of the Adriabukta Formation with mildly deformed competent clastic and carbonate units in overlying Pennsylvanian-Permian units (simply through a single episode of Eurekan contraction-transpression) and the tilted character of Devonian-Mississippian strata in Hornsund prior to Eurekan deformation. What is actually "unbelievable" is that the hypothesis of Ellesmerian deformation managed to survive this long without being challenged, the fact that Dr. Piepjohn did not describe the uncertainty associated to his field observations and interpretations (and, thus, to his models of shallow-crustal Ellesmerian deformation) in any of his available publications, and the fact that Dr. Piepjohn seems to believe that only structural field data can solve geological problems (evidences for a core complex do not necessarily have to be field data). Dr. Piepjohn reproaches the present manuscript of concluding to "the existence of a Devonian core complex just because the Devonian rocks are tilted", while he himself argues (in the present comment) that "there is a very easy explanation for the tilted Devonian rocks in the Adriabukta [...]: the Devonian rocks were folded (F1 and F2 in the Adriabukta $\mathrm{Fm}$ ) and thrust-faulted including the formation of e distinct fracture cleavage before the deposition of the Billefjorden Group: the Ellesmerian deformation!", concluding that "This scenario is much easier to explain than the existence of an assumed core complex". The author of the present manuscript disagrees with the fact that a model involving two episodes of folding and an episode of thrust-faulting is easier than a single episode of core complex exhumation and associated extensional faulting to explain tilted strata in Adriabukta. Comment 37: agreed. The conclusions of the manuscript 
are partly based on observations within one field locality (Pyramiden), which is (as mentioned earlier) a key locality to investigate Ellesmerian contraction since in this area Devonian rocks of the Wood Bay Formation are juxtaposed against uppermost Devonian-Mississippian rocks of the Billefjorden Group. Many groups of geologists (Piepjohn, 2000; Bergh et al., 2011; Braathen et al., 2011) seem to have published maps from this area but only a few have had a close look at outcrops below the mine. Importantly, several groups of geologists map Proterozoic basement rocks below the entrance of the mine in Pyramiden (Piepjohn, 2000; Bergh et al., 2011; Braathen et al., 2011), whereas Russian geologists with access to well data in and around the Pyramiden mine do not (Sirotkin, pers. comm. 2019), which suggests that the geological maps of Dr. Piepjohn for the Pyramiden locality are erroneous. As shown in the present manuscript, Devonian rocks below the entrance of the mine appeared similar to igneous basement rocks because it was not possible to cut thin sections thin enough for proper petrological analysis. After careful examination, it appears that Lower Devonian rocks crop out on both the footwall and the hanging wall of the N-Sstriking fault below the mine entrance in Pyramiden. The present manuscript further discusses multiple possible explanations for the observed structural field relationships, describing the various uncertainties associated with each model (section 5.1 in the present manuscript). Again, the number of structural measurements has nothing to do with the quality of the work done by the author of the present manuscript. A high number of measurements is by no means a proof that a specific hypothesis is true. Using new field data in a key locality to study Ellesmerian deformation and reviewing all field data from exising literature (including thousands of field measurements from Dr. Piepjohn's work and from other works like Bergh et al., 2011; see reply to Dr. Piepjohn's comment 288), the present manuscript shows that adding an extra episode of shallow-crustal (Ellesmerian) contractional and/or transpressional deformation to the protracted tectonic history of Spitsbergen does not provide a satisfactory answer to deformation patterns within Devonian rocks of the Andrée Land Group/Mimerdalen Subgroup, and that deformation patterns in Devonian-Permian rocks throughout

\section{C75}

Printer-friendly version

Discussion paper
Interactive

comment

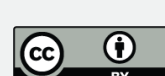


Svalbard are more easily explained by combining the effect of structural mechanisms (e.g., extensional detachment folding and core complex exhumation, and strain partitioning and decoupling by bedding-parallel décollements, duplexes and thrusts) that occurred during two well constrained and well dated tectonic events (Devonian extensional collapse and Eurekan deformation). Comment 38: disagreed. Satellite images (as well as actuall field photographs; Figures 15-25) in Triungen clearly show that the supporters of the Ellesmerian Orogeny cannot use the Triungen locality to argue for Ellesmerian deformation in Dickson Land because the base of the uppermost Devonian-Mississippian Billefjorden Group is completely covered at the location of the speculated Triungen-Grønhorgdalen Fault Zone. The satellite photograph shows as much as Dr. Piepjohn has seen in the field (screes and loose material), and any field data in this specific area cannot possibly support Ellesmerian deformation because the actual contact between folded Lower Devonian and supposedly undeformed uppermost Devonian-Mississippian rocks is not exposed. The contact between tilted Devonian strata and overlying flat-lying uppermost Devonian-Mississippian strata of the Billefjorden Group is exposed c. 100 meters to the east of the TriungenGrønhorgdalen Fault Zone (see Figures 15-25) and corresponds to an angular unconformity. However, the nature of this contact is not appropriate to argue for Ellesmerian deformation since tilting may as well be the result of normal faulting, which is known to have occurred in the area (McCann, 2000 and Figures 15-25 from Koehl et al., in prep. a), and since deformation intensity may siginificantly vary in areas as narrow as 50-100 meters. For example, in Pyramiden, intensely sheared uppermost Devonian-Mississippian coals and coaly shales are separated from overlying and adjacent gently east-tilted (i.e., relatively undeformed) Mississippian sandstones by only a few tens of meters (figures 2 and 3 in present manuscript). Furthermore, black screes along the speculated (because covered by screes and loose material) trace of the fault in Triungen (Figures 15-25 and figure 3c in present manuscript) suggest the presence of coal-rich uppermost Devonian-Mississippian strata of the Billefjorden Group that may (very much like in Pyramiden) have accommodated strain decoupling

\section{C76}

Printer-friendly version

Discussion paper
Interactive

comment

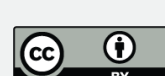


during Eurekan deformation and, thus, be highly sheared and have protected overlying Mississippian-Permian strata from being deformed during Eurekan deformation. Such a simple observation (that of black coal-rich screes) calls for caution and further detailed analysis prior to inferring the occurrence of a whole orogenic event such as Ellesmerian deformation. It is true that the field evidences used to resolve the structural relationships at the Triungen locality are "very poor to nonexistent" (Dr. Piepjohn's comment 38). Regardless, Dr. Piepjohn used them to infer the occurrence of a whole orogenic cycle in the Late Devonian-earliest Mississippian in central Spitsbergen, whereas the author of the present manuscript simply suggests that the observed differences in deformation pattern between tilted Lower Devonian rocks of the Wood Bay Formation and overlying, flat-lying uppermost Devonian-Permian rocks of the Billefjorden Group and Wordiekammen Formation may actually be the product of specific deformation mechanisms (extensional detachment folding and normal faulting, and strain decoupling) during well known tectonic events (Devonian extensional collapse and Eurekan deformation). The satellite photograph shown in figure $3 \mathrm{c}$ in the present manuscript was prefered to field photographs because it shows the overall situation in Triungen, but the author of the present manuscript is open to include field photographs as well (e.g., to the manuscript supplements) or instead of the satellite image. Comment 39: agreed. The present manuscript clearly states that the field data collected by the author of the present manuscript are all from Pyramiden lines 277-281. The author of the present manuscript refers to studies by Bergh et al. (2011) and by Birkenmajer (1964), the latter of which mentions the presence of a folded dolerite sills (most likely of Mississippian or Cretaceous age because there are no other known episode of post-Devonian magmatism in Spitsbergen) within the Adriabukta Formation, thus suggesting that contractional deformation in Adriabukta is most likely Cenozoic in age. The author of the present manuscript does not feel that acquiring more field data in Adriabukta would make any difference to the conclusions of the present manuscript for the Adriabukta area. Ellesmerian contraction is incompatible with the intrusion of potential (Mississippian or) Early Cretaceous sills 
along bedding surfaces of the Adriabukta Formation. If the Adriabukta formation was already tightly folded, the (Mississippian or) Early Cretaceous sills would have intruded the formation by cutting through folds and bedding surfaces (which is not the case since they intruded parallel to bedding surfaces). Thus, it is reasonable to assume that bedding surfaces of the Adriabukta Formation were most likely still sub-planar and not folded in the Early Cretaceous to allow the intrusion of the sills along individual bedding surfaces. The Early Cretaceous sills and sedimentary strata were most likely folded together with strata of the Adriabukta Formation during subsequent Eurekan deformation. The author of the present manuscript wonders whether the publication of Dr. Piepjohn in Adriabukta contains actual field photographs (instead of just idealized conceptual sketches as in Piepjohn et al., 1997a and Piepjohn, 2000). Unfortunately, the author of the present manuscript does not have access to this specific contribution of Dr. Piepjohn's work. Comment 40: agreed. The author of the present manuscript went to a great deal of struggles to get access to all the contributions referenced in the present manuscript, mostly because these were not available on any online repository (e.g., Piepjohn et al., 1997a; Michaelsen et al., 1997; Kempe et al., 1997; Dissmann and Grewing, 1997; Michaelsen, 1998; Roy, 2007; Roy et al., unpublished), and also because quite a few of these were published in languages other than English (e.g., Piepjohn et al., 1997a; Michaelsen et al., 1997; Kempe et al., 1997; Dissmann and Grewing, 1997; Michaelsen, 1998; Roy, 2007, 2009). Unfortunately, the author of the present manuscript does not have access to the work by von Gosen and Piepjohn (2001). Dr. Piepjohn should perhaps consider publishing his work in (Diamond and/or Gold) Open Access Journals (such as Solid Earth) or making copies of his work accessible to other researchers at online repositories so that his hypotheses can be further tested and (potentially) replicated by other research teams. The author of the present manuscript can definitely not replicate any of Dr. Piepjohn's interpretation of a Late Devonian-ealiest Mississippian (Ellesmerian) deformation event in Svalbard. The author of the present manuscript further disagrees with Dr. Piepjohn's comment suggesting that the present manuscript "avoids discussion and dispute on the very

\section{C78}

Printer-friendly version

Discussion paper
Interactive

comment 
difficult geology at Adriabukta". The present manuscript shows step by step why Ellesmerian deformation in Hornsund is very unlikely based on new approaches combining observations from several research teams, including that of Dr. Piepjohn, and using simple restorations techniques that have never been used in the areas of interest in Svalbard (again, see sections 5.2, 5.3 and 5.4). The model of Devonian core complex exhumation and Cenozoic strain partitioning and decoupling greatly simplifies the Phanerozoic tectonic history of Svalbard by deleting an unnecessary, poorly constrainted, poorly dated, short-lived episode of contraction/transpression within a period of dominated by regional extension and subsidence (Devonian-Carboniferous). Please note that the author of the present manuscript is willing to incorporate the findings of the study of von Gosen and Piepjohn (2001) in Hornsund, given (of course) that the study is made available to him. Nevertheless, incorporating such findings will only provide for one more alternative to the model presented in figure 7 in the present manuscript: if the Mariekammen Shear Zone is indeed Eurekan in age, then there is no need for a Devonian core complex in Hornsund. However, the arguments presented in the present manuscript and present discussion regarding strain partitioning and decoupling of Eurekan deformation by shales of the Adriabukta Formation would still apply to the Hornsund area (see very similar trend, plunge and geometry of presumed Ellesmerian folds in the Adriabukta Formation and Eurekan folds in overlying/adjacent, post-Mississippian sedimentary rocks in figures $8 \mathrm{~b}$ and 9a in Bergh et al., 2011) and, hence, Ellesmerian deformation would still not be required in Hornsund. Comment 41: disagreed. As mentioned earlier, the real danger is that only one hypothesis gets to be tested. The author of the present manuscript has already explained why the hypothesis of Ellesmerian contraction lacked competing hypotheses (e.g., lack of funding; Chorowicz, pers. comm. 2019) and was perhaps accepted as "truth" by some (like Dr. Piepjohn?) well too early. The only purpose of the present manuscript is to spark again debate and encourage other research teams to test the hypothesis of core complex exhumation in Svalbard developed by Braathen et al. (2018a, 2020) and pursued by Koehl $(2019 a, 2020)$. The strength and weaknesses of the hypoth- 
esis of core complex exhumation in Svalbard will surely be demonstrated in future interdisciplinary contributions (Koehl et al., in prep. a). Dr. Piepjohn seems to believe that only field data can solve the "complex" geology of Svalbard. Again, the author of the present manuscript calls for caution when discussing interpretations based on monodisciplinary approaches (which represent the cornerstone of Dr. Piepjohn's work about the Ellesmerian Orogeny in Svalbard) and encourages geoscientists to use interdisciplinary approaches. The present manuscript does present serious arguments in discussing reinterpretation of obvious errors/overinterpretation in Dr. Piepjohn's work, e.g., wrong kinematics of the upper Munindalen thrust (see actual field photographs in Michaelsen, 1998), erroneous age for the Plantekløfta Formation in Piepjohn et al. (2000; see supplements in Berry and Marshall, 2015, who are actually experienced paleontologist and palynologist), and overinterpreted outcrop transects (see ). The comment of Dr. Piepjohn suggesting that "Very fast assumptions turn into "truth"' can easily be applied to Dr. Piepjohn's own work about the Ellesmerian Orogeny in Svalbard, in which he shows no field photographs to support his models but instead shows idealized conceptual sketches based on distant indirect obsevations involving high amounts of interpretation (with no description of the amount and nature of the uncertainty involved) of partly-mostly covered (by screes) and inaccessible outcrops (e.g., Piepjohn et al., 1997a; Michaelsen et al., 1997; Piepjohn, 2000). In addition, the relevance of the field data acquired by Dr. Piepjohn towards supporting the hypothesis of shallow-crustal Ellesmerian deformation in Spitsbergen could only be assessed if these data were described with their associated uncertainties, which is not the case since these uncertainties were not described in Dr. Piepjohn's work. Comment 42: partly agreed. The figure quality will be improved. However, the author of the present manuscript received formal training in interpreting seismic data while working in the hydrocarbon industry in Norway (eight formal courses within two years) and while doing his Master's and Ph.D. degrees at the University of Tromsø (three formal courses resulting in relevant publications, e.g., Koehl et al., 2018) for a total of ten years of experience (including five years of supervised experience). Thus, despite

Printer-friendly version

Discussion paper
Interactive

comment

\section{Discussion paper}

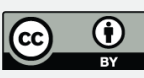


his relatively young age, the author of the present manuscript still feels that his own eyes are more trained and experienced than those of Dr. Piepjohn to interpret seismic data. Despite the fact that "it is always difficult to interpret the stratigraphy in seismic sections", the present manuscript still presents arguments and evidences supporting the conclusion reached (e.g., section 4.2.3). The author of the present manuscript conceeds that the presence of Devonian deposits "east of the Billefjorden Fault Zone in eastern Nordenskiöld Land, cannot be really answered". However, the author of the present manuscript does present and discuss arguments that support the presence of Devonian sedimentary rocks of the Andrée Land Group east of the Balliolbreen Fault and also discusses the uncertainty around the correlation of the Balliolbreen Fault across Sassenfjorden, and, thus, around potential Devonian rocks in Reindalspasset actually being located east of the Balliolbreen Fault (this fault may not continue to the south). In addition, the present manuscript tied the seismic data presented in figure 4 in the manuscript to the exploration well in Reindalspasset. What the author of the present manuscript feels was "over-interpreted" are the outcrop transects used by Dr. Piepjohn for his interpretation of field structural relationships in central and northern Spitsbergen and to support Ellesmerian deformation. Field photographs of some of these transects are actually provided here (Figures 2-25) and clearly show the large amounts of uncertainty involved in Dr. Piepjohn's field interpretation and resulting idealized sketches in Piepjohn et al. (1997a) and Piepjohn (2000). Comment 43: partly agreed. Again, Dr. Piepjohn seems to consider that only field data can be used as arguments to solve geological problems. However, interpreting seismic data has proven to be a valuable tool, e.g., for researchers in geology (e.g., Phillips et al., 2016, 2018, Koehl et al., 2018) but also for the hydrocarbon and mining industries leading to numerous major discoveries. Dr. Piepjohn cannot simply disregard 30 years of significant scientific advancements in the fields of geophysics and sesmic interpretation, and the contribution these data bring to the understanding of the regional geology of Spitsbergen. In addition, the author of the present manuscript shows how onshore observations may directly correlate with observations on seis- 
mic data (e.g., duplexes in uppermost Devonian-Mississippian coals in the field in Pyramiden and on seismic data in Sassengfjorden), thus supporting that seismic data may actually be a powerful resource to resolve the geology of "complex" areas like Svalbard. Moreover, seismic data are not covered by screes and show actual data that are laterally and vertically continuous, which contrasts with the outcrop transects used by Dr. Piepjohn to infer Ellesmerian deformation in Dickson Land (see the poor continuity of bedrock in place in these transects in Figures 2-25). It is correct to say that "In the presented manuscript, the interpretation is careful". The author of the present manuscript is aware that the model he presents might not reflect the ultimate truth. By developing a "careful" argumentation and discussion, the present manuscript shows what the main uncertainties surrounding the presented model are, which contrasts with most of Dr. Piepjohn's work where the uncertainty associated to his questionable (over-) interpretation of poorly exposed and partly inaccessible outcrop transects is almost never discussed. After carefully examining field photographs of these outcrop transects, the author of the present manuscript is of the opinion that the amount of uncertainty involved in Dr. Piepjohn's interpretation and resulting idealized sketches and models (of Ellesmerian deformation) is relatively high, which therefore opens the door to potential reinterpretations (some of which are discussed in the present manuscript and the present discussion; e.g., reinterpretation of figure 53 in Michaelsen, 1998). Comment 44: agreed. Comment 45: partly agreed. The geology of Svalbard and the Pearya terranes were completely different. Work in progress shows that the Barents Sea (Klitzke et al., 2019) and Svalbard (Koehl, 2019a, 2020) are crosscut by thousands of kilometer-long, WNW-ESE- to NW-SE-striking Timanian (650-550 Ma) faults that suggest that the presumed three terranes consistuting Svalbard, which supposedly were accreted during the Caledonian and Ellesmerian orogenies through thousands of kilometer-long movement along N-S-striking faults such as the Billefjorden Fault Zone and the Great Glen Fault (e.g., Harland et al., 1974; Labrousse et al., 2008), were already juxtaposed together before Caledonian and Ellesmerian contractional events. The presence of Timanian faults throughout

Interactive comment
Printer-friendly version

Discussion paper

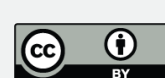


Svalbard and the Barents Sea further suggests that the tectonic plates constituting present day Arctic regions were much more stable than previously anticipated. In addition, paleomagnetic and geochronological data from Michalski et al. (2017) do not support reconstructions linking Pearya to western Svalbard. The claim of Dr. Piepjohn suggesting that "Spitsbergen was located somewhere north of northern Greenland at least since Early Carboniferous times" is only based on speculation since very similar sedimentary units may deposit synchronously in various parts of the world simply requiring similar environmental setting and sedimentary input, e.g., Devonian successions in Svalbard and Scotland, which (based on the presence of Timanian faults throughout Svalbard) were separated by thousands of kilometers but still show very similar sedimentary successions, and Carboniferous redbeds of the Hultberget Formation (Cutbill et al., 1976) in Svalbard and the Barents Sea and contemporaneous redbeds of the Farallones Group in central Colombia (Mora et al., 2006). The present manuscript does not attempt to discuss Ellesmerian deformation outside of Svalbard, although (as pointed out in the last paragraph of the conclusion), it may have implications for Ellesmerian deformation elsewhere. Shallow-crustal to near surface Ellesmerian deformation (i.e., Late Devonian-earliest Mississippian contractional to transpressional deformation in near-surface sedimentary rocks like those of the Andrée Land Group and Mimerdalen Subgroup) is poorly dated and no geochronological data can definitely segregate it from Caledonian, McClintock and Eurekan deformation in Svalbard, Greenland and Arctic Canada. Thus, Dr. Piepjohn cannot use its speculated occurrence in other parts of the world to justify its happening in Svalbard. The author of the present manuscript emphasizes the fact that latest Devonian-earliest Mississippian geochronological ages obtained in western Spitsbergen (e.g., Schneider et al., 2018) related to a shear zone (the Bouréefjellet Fault Zone) that shows normal sense of shear is much more likely to be related to core complex exhumation than contractional Ellesmerian deformation (see present manuscript's section 5.4). The author of the present manuscript is not convinced by any evidence in any part of the world presented thus far to support (shallow-crustal) Ellesmerian deformation,

Interactive comment
Printer-friendly version

Discussion paper

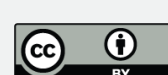


but has no problem with Late Devonian-Mississippian, (prograde) amphibolite- to eclogite-facies metamorphism in western Svalbard (e.g., Kosminska et al., 2020) and northeastern Greenland (Gilotti et al., 2004; McClelland et al., 2006) representing continued, deep, late (final) Caledonian contraction coeval with continuous, DevonianMississippian, shallow-crustal to near-surface, collapse-related extension both in northeastern Greenland (Stemmerik et al., 1991; Strachan, 1994; Larsen et al., 2008) and Svalbard (Manby and Lyberis, 1992; Koehl and Muñoz-Barrera, 2018; Braathen et al., 2018a, 2020). More work is definitely needed to support or invalidate the poorly constrained episode of Ellesmerian deformation, e.g., finding amphibolite-facies metamorphism in Devonian sedimentary rocks, or reverse shear zones or faults yielding Ellesmerian ages, or tight folds or faults with clear reverse kinematics just below (i.e., truncated by) a post-Devonian unconformity with outcrops showing both the preserved unconformity and the preserved reverse fault and/or tight fold truncated by the unconformity. Noteworthy, Roberts (1983) mistakenly ascribed fold structures in Devonian collapse basins in western Norway to Ellesmerian/Svalbardian deformation. These fold structures are now known to represent transtentional folding reflecting large amounts of (constrictional) extension (Chauvet and Séranne, 1994; Osmundsen and Andersen, 1994; Fossen et al., 2013). Hence, if such a mistake occurred in western Norway, it is conceivable that it may have occurred in other parts of the world, possibly in Svalbard as suggested in the present manuscript. Comment 46: agreed, though the author of the present manuscript is aware that the figure captions in the manuscript are probably too long. Comment 47: agreed. Comment 48: agreed. Comment 49: agreed. Comment 50: disagreed. Figure $3 \mathrm{c}$ in the manuscript clearly demonstrate (without having to go to the locality) that the conclusions of previous studies including those of Dr. Piepjohn suggesting the presence of folded Devonian (although correct) overlain by undeformed (uncertain because covered by screes along the Triungen-Grønhorgdalen Fault Zone) uppermost Devonian-Mississippian strata of the Billefjorden Group are based on interpretation/speculation of what lies below the screed along the Triungen-Grønhorgdalen Fault Zone. Undeformed (tilted) 
Lower Devonian rocks unconformably overlain by undeformed (flat-lying) uppermost Devonian-Mississippian strata several hundred meters east of the fault (i.e., where sedimentary strata of the Billefjorden Group and Andrée Land Group actually crop out) may not reflect the state of deformation of strata of the Billefjorden Group along the fault. The satellite image in figure $3 \mathrm{c}$ in the manuscript shows that a similar case scenario as to that in Pyramiden may be relevant for the Triungen locality (and, possibly, for other localities throughout Spitsbergen) supposedly pin-pointing the timing of shallow-crustal to near-surface Ellesmerian deformation (Rippington et al., 2010). Structures similar to those evidenced in uppermost Devonian-Mississippian coals and coaly shales in Pyramiden in the present manuscript may well be present in localities like Triungen and, thus, the interpretation of Ellesmerian deformation should be re-examined and the localities used to pin-point it (e.g., Triungen) should be reinveastigated with direct outcrop observations (not from the distance and not of outcrops covered by screes or inaccessible). At the locality targeted by figure 3c in the manuscript (Triungen), the author wants to draw the attention of the reader to the high level of uncertainty involved in the interpretation outcrop transects by supporters of Ellesmerian deformation like Dr. Piepjohn. Based on actual outcrop data and observations of structures in bedrock in place in Pyramiden, a similar scenario is envisioned for the Triungen locality, i.e., coal-seated (partial) Eurekan décollements and/or duplexes decoupling deformation between gently folded Lower Devonian rocks and presumably undeformed uppermost Devonian-Mississippian rocks. Again, the author of the present manuscript is open to replacing the satellite image in figure $3 \mathrm{c}$ in the manuscript by an actual field photograph (or several) of the Triungen locality. Regardless, interpreted and uninterpreted field photographs of the Triungen locality will be attached to the present manuscript and are shown in the present discussion (Figures 15-25). Comment 51: agreed. Figure quality will be improved. Comment 52: agreed. Despite the fact that the debate around the age of the Adriabukta Formation (and whether it belongs to the Billefjorden Group or Andrée Land Group/Mimerdalen Subgroup) is irrelevant for figure 5 (the one in the 
manuscript), Dr. Piepjohn brings up a very important and relevant question for the scope of the present manuscript that is not yet addressed in the present manuscript. The debate around the age of the Adriabukta Formation is indeed relevant when discussing the timing of Ellesmerian deformation in Spitsbergen, further highlighting the timing inconsistencies of this tectonic event throughout Spitsbergen, thus further reinforcing the doubts surrounding its occurrence and supporting the alternative model detailed in the present manuscript. Palynomorphs from black shales at the base of and within the Adriabukta Formation most probably suggest a lowermost Visean age (Birkenmajer ad Turnau, 1962). The debate around the palynological ages obtained by Birkenmajer and Turnau (1962) from the analysis of 350 spore specimens (i.e., not from only one erroneously identified specimen like in Piepjohn et al., 2000) is only based on structural correlation between supposed Ellesmerian/Svalbardian structures in the Adriabukta Formation with supposed Ellesmerian/Svalbardian structures in rocks of the Andrée Land Group and Mimerdalen Subgroup in northern and central Spitsbergen (Dallmann et al., 1999; Bergh et al., 2011; Dallmann and Piepjohn, submitted). The present manuscript clearly shows that the segregation of Ellesmerian from Eurekan structures in the Adriabukta Formation is highly doubtful since inferred Ellesmerian fold structures in the Adriabukta Formation show similar trend, plunge and geometry as Eurekan folds in overlying post-Mississippian sedimentary rocks in southern Spitsbergen (see Bergh et al., 2011, their figure 8b and 9a). Thus, the questioning of the Mississippian (lowermost Visean) ages obtained by Birkenmajer and Turnau (1962) is only speculative and, as noted by Dallmann et al. (1999), the folding of the Adriabukta Formation "cannot be correlated with the Svalbardian folding". Note that Prof. Turnau was a paleobotanist, i.e., highly qualified specialist in dating microspore. The initiation of the hypothesis that the Adriabukta Formation is actually Late Devonian in age instead of Mississippian is described in Bergh et al. (2011) citing "W. Dallmann pers. comm. 2009", i.e., neither based on any published material, nor on scientific evidence. On the contrary, later palynological studies in Svalbard and Europe support the lowermost Visean age of Birkenmajer and Turnau (1962). The presence

Interactive comment
Printer-friendly version

Discussion paper

\section{C86}


of Lycospora, Tripartites and Triquitrites identified by Birkenmajer and Turnau (1962) within the Adriabukta Formation is characteristic of the (base) Visean (Hughes and Playford, 1961; Playford, 1962, 1963; Clayton et al., 1977; Lopes et al., 2018a). Thus, the debate around the Mississippian ages obtained for the Adriabukta Formation by Birkenmajer and Turnau (1962) is not justified. The fact that Mississippian (Visean) sedimentary rocks of the Adriabukta Formation in southern Spitsbergen are tightly folded simply further highlights the lack of consistency and high amounts of uncertainties around the occurrence of Ellesmerian deformation in Svalbard, and further supports that fold structures within the Adriabukta Formation formed during Eurekan deformation due to strain partitioning/decoupling in weaker shales of the Adriabukta Formation. In addition, the possibility that the relatively more deformed character of the Adriabukta Formation arises from the dominance of shally (i.e., weaker) lithologies in this Formation (as argued for in the present manuscript) was already suggested by Birkenmajer and Turnau (1962). Comment 53: agreed. However, the legend in figure 5 in the manuscript applies to both figure 5 and figure 7 (see line 2057 in the present manuscript). A repetition of the same legend in both figures would only lengthen a manuscript already quite long (see Dr. Piepjohn's comment 11). Comment 54: the authot of the present manuscript fails to understand how Dr. Piepjohn suggests a 5-6 kilometer-thick Adriabukta Formation undernearth the Hyrnefjellet Formation. Thicknesses are only approximative and the Adriabukta Formation is Hornsund is no thicker than 600 meters cumulated (Birkenmajer, 1964). Or is Dr. Piepjohn suggesting that the Adriabukta Formation should be 5-6 kilometers thick in figure 5? The present manuscript and figure 5 do not attempt to discuss the boundary of the Adriabukta Formation to the east. Figure $5 b$ in the manuscript shows a frame with a zoom in the restored western portion of the Adriabukta transect shown in figure 5a. In their manuscript, Bergh et al. (2011) show that the Mariekammen Shear Zone also involved a component of reverse offset. After restoration prior to early Cenozoic folding (which occurred in the area as testified by folded post-Mississippian sedimentary strata), the Mariekammen Shear Zone displays offset geometries comparable to that of a normal

Printer-friendly version

Discussion paper
Interactive

comment

\section{C87}


fault rather than reverse (possibly with a strike-slip component that is not discussed in the present manuscript). Comment 55: disagreed. There are indeed evidences that suggest the presence of rocks of the Andrée Land Group/Mimerdalen Subgroup east of the Balliolbreen Fault, including the interpretation of seismic data in Reindalspasset and the interpretation of field relationships and thin section analysis in both the hanging wall and footwall of a subvertical, east-dipping brittle fault (possibly corresponding to the Balliolbreen Fault) below the mine entrance in Pyramiden showing Lower Devonian sandstones on both sides of the fault (figures 2 and $4 \mathrm{~g}$, and supplement $\mathrm{S} 1$ in manuscript). In addition, recent interpretation of seismic data and depth conversion (based on exploration well data in Spitsbergen and the Barents Sea) in Billefjorden east and west of the Balliolbreen Fault suggest that the Devonian ORS deposits are c. 2.7-4.0 kilometers thick just west of the fault (Koehl et al., in prep. a), i.e., not as thin as Dr. Piepjohn seem to believe. The author of the present manuscript is uncertain on what scientific evidence (sedimentary log? Observation on particular outcrops? other?) Dr. Piepjohn bases his assumptions of an "extremely thin" ORS succession near the Balliolbreen Fault since Dr. Piepjohn himself wrote in his comment 55 that "the base of the ORS-sandstone west of the Balliolbreen Fault is absolutely unknown", adding that "Neither the depth of the basement is known". Both of these issues (the base of the ORS and depth of the basement) are addressed in Koehl et al. (in prep. a, a; see Figure 28 from this manuscript in preparation). Comment 56: agreed, though Dr. Piepjohn probably means figure "6d". In the model shown in figure $6 \mathrm{~d}$ in the manuscript, the "kilometer-scale folds and thrusts of the Dickson Land fold-and-thrust zone" within rocks of the Andrée Land Group and Mimerdalen Subgroup are not shown in detail. Only the main anticline east of Pyramiden is shown because smaller, intra-Andrée Land Group/Mimerdalen Subgroup Cenozoic folds are not the main point illustrated figure 6. All these folds are suggested to have formed during Eurekan deformation. Comment 57: partly agreed. The figure quality will be improved. The small sketches in figure $6 e$ in the manuscript fit field observations of the author of the present manuscript in Pyramiden, and field observations by other authors in the

Interactive comment
Printer-friendly version

Discussion paper

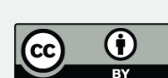


other localities discussed in the text lines 828-900 (including field observations by Harland et al., 1974; Lamar et al., 1982, 1986; McCann, 1993; Lamar and Douglass, 1995; Dallmann et al., 2004; Koehl and Muñoz-Barrera, 2018). Again, the author of the present manuscript uses both his and others field observations to reinterpret key geological transects in Spitsbergen. Dr. Piepjohn is correct when he writes that "all observations do not argue against the Ellesmerian deformation!". However, many observations do indeed contradict the concept of Ellesmerian deformation in Spitsbergen (e.g., Mississippian timing of of folding in Adriabukta - Birkenmajer and Turnau, 1962; 3 Myr time span for Ellesmerian deformation - see reply to Dr. Piepjohn's comment 19; the opposite vergence of supposed Ellesmerian folds and thrust in southern and northern Spitsbergen - see reply to Dr. Piepjohn's comment 26; the presence of Eurekan, bedding-parallel décollements, thrusts and duplexes within uppermost Devonian-Mississippian strata of the Billefjorden Group and at the base of the Wordiekammen Formation - figure $3 \mathrm{~b}$ in the manuscript and Figure 28 from Koehl et al., in prep. a), whereas no observations (not interpretations) contradict the model presented in the present manuscript. Comment 58: disagreed. Figure 7 in the manuscript, though simplified, shows that core complex exhumation in Hornsund may better explain the normal kinematics of the Mariekammen Shear Zone and reconcile them better with angular unconformities between the Marietoppen, Adriabukta and Hornsundneset formations than Ellesmerian deformation. Again, Dr. Piepjohn is simply asking about field evidence. Some evidence for N-S- to NNW-SSE-trending core complexes throughout Spitsbergen actually are based on field observations in northwestern Spitsbergen (Braathen et al., 2018a, 2020). These are easily tied to the southern continuation of the Bockfjorden Anticline core complex on seismic data in Isfjorden (also mapped as a basement ridge by Bergh et al., 1997, their figure 10) and on aeromagnetic data throughout Spitsbergen showing that these core complexes correlate with positive aeromagnetic anomalies. A similar positive aeromagnetic anomaly is visible where basement crops out in Hornsund, thus potentially supporting the presence of a core complex there too. These results will be published in a future 
manuscript but are already available online as part of Koehl (2019b). The author of the present manuscript is aware that "Going to the area south of Hornsund, Adriabukta $\mathrm{Fm}$ is unconformably overlying crystalline basement rocks east of the main Devonian exposures". A core complex actually reconciles such an unconformity between the Adriabukta Formation and basement rocks by continued core complex exhumation and erosion/non-deposition of the Marietoppen Formation on the crest of the core complex and, later on, deposition of Adriabukta Formation on the crest of the core complex during decreasing core complex exhumation. The angular unconformity between the Adriabukta and Hornsundneset formations suggests that core complex exhumation persited into the Mississippian. The core complex's crest located west of Adriabukta north of Hornsund is offset left-laterally by several (3-5) kilometers by a major inherited, WNW-ESE-striking Timanian fault that was reactivated and overprinted during Caledonian and Eurekan deformation and Devonian-Carboniferous extension, and continues southwards in Påskefjellet where it is overlain unconformably by the Adriabukta Formation (see Koehl, 2019b). Comment 59: agreed. It is because the Hornsundneset Formation is not present in Adriabukta and because the color legend in figure 5 also applies to figure 7 in the manuscript (where the Hornsundneset Formation is shown; see reply to Dr. Piepjohn's comment 53). Comment 60: agreed. However, the author of the present manuscript argues that Roy et al. (unpublished) is indeed a valid reference that will be made available online as part of the Rock Vault Project at the University Center in Svalbard (www.svalbox.no/srv). Comment 61: the legend of the blue shader is incorrect since sedimentary rocks of the Billefjorden Group are indeed deformed in Pyramiden (see figures 2 and $3 b$ in the manuscript) and rocks of the Wordiekammen Formation are deformed in Robetsonbreen (2-3 km northwest of Kilen; Dissmann and Grewing, 1997). In addition, Dr. Piepjohn describes the red lines in his figure 1 in the present discussion as a potential regional "Eurekan detachment". The author of the present manuscript thinks that this is incorrect in many places (although not possible to tell for certain because the contact is covered by screes of the Wordiekammen Formation and/or inaccessible as shown in Figures

Interactive comment
Printer-friendly version

Discussion paper

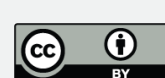


2-25) and that the contact between tilted (folded in places) strata of the Andrée Land Group/Mimerdalen Subgroup and uppermost Devonian-Permian strata of the Billefjorden Group and Wordiekammen Formation mostly corresponds to an angular unconformity. However, this contact is locally tectonized (e.g., in Pyramiden in figure $3 \mathrm{~b}$ in the present manuscript, and in Birger Johnsonfjellet as shown in the figure 5.6 in McCann, 1993), thus explaining the deformation differences between generally undeformed Billefjorden and Gipsdalen groups and tilted-folded rocks of the Andrée Land Group/Mimerdalen Subgroup. Examples of such detachments-décollements between the Wood Bay Formation and Wordiekammen are further described in Koehl et al. (in prep. a) and in the Figure 28 and Figure 29. The map provided by Dr. Piepjohn further illustrates the point made by the author of the present manuscript in the present discussion and in the present manuscript, i.e., that most presumed Ellesmerian thrusts were interpreted/inferred from great distance and are actually tentative (e.g., Muninbreen Fault) or were misinterpreted (e.g., upper Munindalen thrust; see reply to comment 28), therefore leaving ample room for doubts and debate about the occurrence of shallow-crustal Ellesmerian deformation in Devonian strata in Spitsbergen. Comment 62: agreed. The figure of Dr. Piepjohn illustrates clearly the situation in Spitsbergen. Transport directions along Eurekan thrusts (in the view of the author of the present manuscript, all Ellesmerian thrusts are Eurekan thrusts apart for a few misinterpreted Devonian normal faults and/or stratigraphic unconformities) contrast between northern and southern Spitsbergen. The author of the present manuscript is currently writing a short paper about this issue based on new findings of several kilometers thick Timanian thrust systems in Storfjorden and throughout Spitsbergen (Koehl, 2019a, 2019b, 2020). The most important of these thrusts extends from Kongsfjorden to Sassenfjorden and Storfjorden, and merges with Timanian thrusts described in Klitzke et al. (2019) in the northern Barents Sea. This thrust accommodated kilometer-scale $(4-12 \mathrm{~km})$ reverse-sinistral movements during Eurekan deformation and partitioned deformation between northern and southern Spitsbergen (Koehl, 2019a, 2019b, 2020), thus explaining the opposite transport di-

Printer-friendly version

Discussion paper
Interactive

comment

\section{C91}


rection and opposite vergence of Eurekan folds in northern and southern Spitsbergen and, hence, implying that all fold structures in Devonian strata of in Andrée Land and Dickson Land are early Cenozoic contractional-transpressional folds or Devonian extensional folds. Thus, Ellesmerian contraction is not required anymore to explain deformation structures in Spitsbergen. A specific example from Dr. Piepjohn's figure 2 proving that his use of the vergence of Eurekan and presumed Ellesmerian structures to distinguish them from each other does not work and should not be trusted is that Eurekan folds and thrusts in Bünsow Land show the exact same westwards transport direction as supposed Ellesmerian thrusts in adjacent areas in Dickson Land, thus further supporting that potential Ellesmerian folds and thrusts in Dickson Land are actually Cenozoic in age and that the model presented in the present manuscript (involving early Cenozoic strain partitioning and decoupling) is more appropriate and more robust to explain deformation patterns in post-Caledonian sedimentary rocks throughout Spitsbergen. Comment 63: disagreed. The present manuscript does not argue for a regional detachment between Devonian and Carboniferous-Permian strata (especially not in Pretender), but rather for local detachments and décollements (e.g.,figure $3 b$ in present manuscript, and Figure 28 and Figure 29 discussed in Koehl et al., in prep. a). In Pretender, Devonian strata are located above the southwards prolongation of the crest of the Bockfjorden Anticline core complex and, thus, do not require any detachment/décollement to be at a slight angular unconformity with the uppermost Carboniferous-lowermost Permian Wordiekammen Formation. Continuous core complex exhumation in this area left Devonian strata barely tilted (sub-horiontal bedding), whereas in Dickson Land late-post-Caledonian extension and associated normal faulting along both $\mathrm{N}-\mathrm{S}$-striking detachements (e.g., Woodfjorden Detachment; Roy, 2007, 2009; roy et al., unpublished) and WNW-ESE-striking faults (Koehl et al., in prep. a and Figure 28 from Koehl et al., in prep. a) may have significantly tilted Devonian strata, which were reworked by subsequent Eurekan deformation along both fault sets. Comment 64: disagreed. New paleontological and palynological studies by experts in these fields clearly suggest a Famennian age for the base of the 
Billefjorden Group and an older (Givetian-earliest Frasnian) age for the Planteryggen and Plantekløfta formations (Scheibner et al., 2012; Lindeman et al., 2013; Berry and Marshall, 2015; Marshall et al., 2015; Newman et al., 2019; Lopes, pers. comm. 2019), i.e., disproving the age advocated by Dr. Piepjohn's studies (see supplements in Berry and Marshall, 2015). Thus, Ellesmerian deformation in Spitsbergen (if it ever occurred) initiated and terminated in the Late Devonian. Comment 65: agreed. Comment 66: agreed. Comment 67: one of the main argument of supporters of Ellesmerian deformation in Svalbard is that the Balliolbreen Fault accommodated reverse movements in the Late Devonian, thus leading to erosion of Devonian sedimentary rocks of the Andrée Land Group and Mimerdalen Subgroup east of the fault. The potential presence of such sedimentary strata east of the potential continuation of the Balliolbreen Fault in Reindalspasset suggests otherwise. Comment 68: Dr. Piepjohn's comment is not clear. When Dr. Piepjohn writes that "Devonian rocks and underlying basement are exposed west of the BFZ", if he means west of the Odellfjellet Fault, agreed, if he means west of the Balliolbreen Fault, disagreed because basement rocks underlying Devonian rocks of the Andrée Land Group and Mimerdalen Subgroup are not exposed west of the Balliolbreen Fault. In addition, when he writes that "basement rocks (and eroded Devonian) [are exposed] east of the BFZ", it does not make sense because "eroded Devonian" cannot be exposed. The author of the present manuscript refers Dr. Piepjohn to figure 6 and the discussion (section 5.1) in the present manuscript for further explanation. The exposure of Proterozoic basement (in places) just east of the Balliolbreen Fault may be explaned by normal faulting and footwall uplift during the Devonian-Carboniferous and subsequent significant inversion of the Balliolbreen Fault in early Cenozoic times. Comment 69: Dr. Piepjohn may want to support his claim that "Eurekan movements along the Billefjorden Fault Zone are not very large" with relevant data and evidences, and mention what type of data he is basing such interpretation on (especially if these data are field observations made from great distance and on outcrops mostly covered by screes and inaccessible). Regardless, Eurekan movements along the Billefjorden Fault Zone do not need to be very large for

Printer-friendly version

Discussion paper
Interactive

comment

C93 
the model argued for in the present contribution to be correct. The fact that Eurekan reverse movements along the Billefjorden Fault Zone do not need to be very large does not mean that Devonian rocks of the Andrée Land Group and Mimerdalen Subgroup could not have experienced intense deformation due to strain partitioning and decoupling. Comment 70: disagreed. The present paper does not attempt to prove that the contact of Devonian rocks with uppermost Devonian-Mississippian rocks of the Billefjorden Group or with uppermost Carboniferous-lowermost Permian strata of the Wordiekammen Formation is a regional detachment. As Dr. Piepjohn mentions, these contacts are, in places, well exposed and physically accessible and, indeed, correspond to angular unconformities, e.g., in figure $3 \mathrm{c}$ in the present manuscript a satellite image shows exposed Lower Devonian strata of the Wood Bay Formation overlain by coal-rich strata of the Billefjorden Group c. 200-400 meters away from the speculated location of the Triungen-Grønhorgdalen Fault Zone. However, these contacts are, in most places, covered by screes and/or inaccessible (Figures 2-25) to investigate whether they are tectonized by mesoscale structures like observed in Pyramiden. In Triungen, figure 3c (in the manuscript) shows that one cannot rule out the occurrence of coal-seated (partial) Cenozoic décollements along the speculated trace of the Triungen-Grønhorgdalen Fault Zone as shown by the presence of black (coal-related) screes. Based on the presence of such bedding-parallel décollements and duplexes in Pyramiden, where strata are actually well exposed in the narrow area of interest, the local presence of such duplexes and partial décollements in Triungen along the (covered) fault surface is regarded as highly likely. The present manuscript aims at highlighting the weaknesses of key arguments used by Dr. Piepjohn and other workers to argue for Ellesmerian deformation in specific localities upon which the whole Ellesmerian hypothesis is based. For example, the present manuscript and present discussion show the high level of uncertainty around Dr. Piepjohn's observations and interpretations, the former of which were made from great distance and/or on partly-mostly covered (by screes) and discontinuous outcrop transects and are, therefore, inappropriate to discuss the

Interactive comment
Printer-friendly version

Discussion paper 
local presence of mesoscale structures in the field (i.e., visible by actually physically visiting the outcrops) or on continuous transects (such as seismic sections). By comparison, the contact between the Andrée Land Group/Mimedalen Subgroup and the overlying Billefjorden Group is relatively better constrained in Pyramiden, though its nature is not $100 \%$ certain everywhere at this locality as mentioned in the present manuscript (lines 354-362). Comment 71: disagreed. May Dr. Piepjohn illustrate his doubt that the great differences in deformation along the BFZ on the one hand and in the fold-and-thrust zones in the ORS basin (and in the basement at the west coast of northern Spitsbergen)" are not related to strain partitioning and/or decoupling? Otherwise, such doubts are only assumptions. The present manuscript shows recent interpretation of actual (physically visited) outcrop data and seismic data illustrating this point (figures 3 and 4 in the present manuscript). In addition, the claim of Dr. Piepjohn that the present manuscript's model "would only be correct if the base of the Billefjorden/Gipsdalen groups between BFZ and the WSFBT is be a detachment" is also not supported by any scientific evidence or argument and is definitely not the point of the present manuscript, which argues for the presence of local strutures (décollements, thrusts, duplexes) partitioning and decoupling Eurekan deformation. The author of the present manuscript also notifies that he has indeed investigated the "kilometer-scale structures in the Devonian west of the Balliolbreen Fault in central Dickson Land" (see Figures 2-25) but found that these were irrelevant to distinguish Ellesmerian deformation from Eurekan deformation and to discuss early Cenozoic strain partitioning/decoupling. Notably, it is clear that scientists have, thus far, failed to identify discrete trends and strikes that distinguish Ellesmerian from Eurekan structures in Devonian rocks in Spitsbergen (e.g., Dr. Piepjohn's comment 25 on the vergence of Ellesmerian and Eurekan structures). Some of the most relevant examples are the sub-parallel trends of Eurekan and Ellesmerian folds in Hornsund in Bergh et al. (2011, their figures $8 \mathrm{~b}$ and 9a), which actually support a single episode of tectonism (i.e., the model argued for in the present manuscript) rather than two superimposed contractional events (as argued by Dr. Piepjohn and others). Further- 
more, early Cenozoic strain partitioning (including decoupling) is clearly demonstrated by observations made on (physically visited) outcrops in Pyramiden showing folded Devonian rocks of the Andrée Land Group/Mimerdalen Subgroup (those mentioned by Dr. Piepjohn), strongly sheared uppermost Devonian-Mississippian strata of the Billefjorden Group (partitioning/decoupling the deformation) and undeformed/gently tilted Pennsyvlanian-Permian strata, and by structural and stratigraphic analysis of seismic data in nearby areas in Sassenfjorden-Tempelfjorden showing partitioning/decoupling of early Cenozoic deformation between widespread top-NNE Cenozoic thrusts within the weak evaporitic-carbonate strata of the Gipshuken Formation and localized top-SSW early Cenozoic thrusts within rocks of the Hultberget, Ebbadalen, Minkinfjellet and Wordiekammen formations (figure $4 \mathrm{a}-\mathrm{c}$ in the present manuscript). Even internal beds within the Lower Devonian rocks of the Wood Bay Formation show evidence for strain partitioning/decoupling between poorly deformed (gently folded/tilted) sandstone-siltstone-dominated units (Figure 30) and more shaly units affected by shear surfaces and cleavage down in the valley (Figure 31), i.e., away from the unconformity with Wordiekammen sedimentary rocks (up the mountain; e.g., Figure 2). Such strain heterogeneities are similar to what is observed on seismic data in Billefjorden within Lower Devonian deposits (Figure 28 from Koehl et al., in prep. a). The author of the present manuscript also argues that strain partitioning and decoupling is also supported by several ongoing publications (1) discussing the presence of local décollements along stratigraphic boundary between the Wordiekammen and Wood Bay formations in Billefjorden (Figure 28 from Koehl et al., in prep. a), (2) reconciling observations made but left unexplained by Dr. Piepjohn (Michaelsen et al., 1997; Piepjohn et al., 1997a) with Devonian tectonism, e.g., outcrop with E-W-trending sub-vertical Devonian strata in southern Mimerdalen (Koehl et al., in prep. a), and (3) the presence of major, several kilometers thick inherited Timanian shear zones that extend from northwestern Russia (Olovyanishshnikov et al., 2000) to the northern Barents Sea (Klitzke et al., 2019) and Spitsbergen (Koehl, 2019a, 2019b, 2020; Koehl et al., in prep. b) and partitioned Eurekan deformation between northern and 
southern Spitsbergen. Comment 72: agreed. Dr. Piepjohn is right and this sentence is improperly phrased. Comment 73: agreed. The sentence is not ideally phrased. Comment 74: agreed. Comment 75: agreed. Comment 76: agreed. Comment 77: agreed. Comment 78: agreed. The author of the present manuscript would like to apologize for misspelling Prof. von Gosen's last name. Comment 79: disagreed. Grantz and May (1984), Lane (2007) and Kumar et al. (2011) report an event part of the Ellesmerian Orogeny in Alaska/Yukon. Comment 80: agreed. Comment 81: agreed. Comment 82: agreed. However, they were previously misinterpreted to be part of the Ellesmerian Orogeny. Thus, it is important to mention these previous alternative interpretation to better illustrate our point that Ellesmerian structures actually most likely correspond to misinterpreted Devonian extensional faults and folds and Eurekan folds and thrusts. Comment 83: agreed. However, the present sentence simply states that "The Ellesmerian Orogeny [...] deformed [...] Devonian collapse basins and Precambrian-early Paleozoic basement in [.. .] Svalbard (McCann, 2000; Piepjohn, 2000; Piepjohn et al., 2000" and does not argue that deformation within the ORS is related to extensional collapse. Comment 84: agreed. Comment 85: agreed. Comment 86: agreed. Fold structures in the ORS in Svalbard are younger than the Caledonian Orogeny. However, the interpretation of tectonic structures as Ellesmerian folds and thrusts in the Arctic is still left to be supported by adequate geochronological dating. The sentence simply quotes Rippington et al. (2010) in saying that in many places in the Arctic, structures interpreted as Ellesmerian could as well be Caledonian and/or Eurekan in age. The main exceptions to this trend mentioned by Rippington et al. (2010) are folds and thrusts in Lower-lowermost Upper Devonian sedimentary rocks of the Andrée Land Group and Mimerdalen Subgroup in Dickson Land where they are unconformably overlain by uppermost Devonian-Mississippian strata of the Billefjorden Group (e.g., in Triungen), or so scientists thought. This sentence insists on the fact that a large part of the evidences supporting the occurrence of Ellesmerian deformation event worldwide are located in Dickon Land in Svalbard. The present manuscript shows that presumed Ellesmerian structures in Dickson Land are

Printer-friendly version

Discussion paper
Interactive comment

\section{Discussion paper}

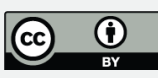


much more likely to have formed as Devonian extensional structures (detachments and transtensional folds) and/or during early Cenozoic Eurekan deformation due to strain partitioning and decoupling, thus casting serious doubts on the hypothesis of Ellesmerian deformation in Svalbard (as discussed in the present manuscript), but also having potential implications for interpreted Ellesmerian deformation in other areas where Upper Devonian sedimentary rocks are not preserved (e.g., northern Greenland) and where the interpretation of Ellesmerian structures is simply based on the pin-pointing of this tectonic episode in Dickson Land (shown to be highly questionable in the present manuscript). Comment 87: disagreed. The arguments used by Dr. Piepjohn and his team to distinguish Ellesmerian from Eurekan structures in Arctic Canada, northern Greenland and Svalbard, notably "transport directions" and "cutting relationships of structures", are inappropriate to support Ellesmerian deformation if one has not considered the possibility of Eurekan strain partitioning and decoupling. In addition, as mentioned by recent contributions (e.g., Fossen, 2020), the methodology used by Dr. Piepjohn and his team including (1) indirect observations and interpretations of outcrop transects from great distance on partly-mostly covered (by screes) and inaccessible outcrop sections and (2) monodisciplinary field mapping (only using field data) to resolve regional tectonic histories, and (3) multiple successive deformation phases to describe geological processes, e.g., for Ellesmerian and Eurekan deformation events (e.g., Piepjohn and Thiedig, 1997a, their table 1; Piepjohn et al., 1997b, their figure 5; Piepjohn et al. 2016, their figure 7; Dallmann and Piepjohn, submitted, their figure 37) needs to be abandoned because it does not account for, e.g., strain partitioning, progressive deformation and soft-sediment deformation, and leads to obvious mistakes, i.e., addition of a whole orogeny where it is not needed, e.g., the Late Devonian-Mississippian Antler Orogeny (solely on the presence of coarse-grained clastic deposits on the flank of an elongated NNE-SSW-trending block and on the presence of a thrust fault now known to be much younger - Cretaceous) in Nevada questioned by Ketner (2012) and, possibly, the Ellesmerian Orogeny discussed in the present manuscript and by Rippington 
et al. (2010). To quote Prof. Fossen (2020): "even if two foliations or a refolding pattern can be distinguished within a field area, this is not proof of two deformation phases". In the light of new evidence from recent and ongoing interdisciplinary studies adopting interdisciplinary approaches (present manuscript and Koehl et al., in prep. a; also see Figure 28), the author of the present manuscript disagrees with Dr. Piepjohn's "careful" interpretation of "the age of tectonic structures (either Ellesmerian or Eurekan) in the Canadian Arctic, North Greenland and Svalbard" because they are all based on indirect, monodisciplinary observations not backed up by any Ellesmerian geochronological age in shallow-crustal sedimentary rocks in Svalbard (again, the Late Devonian-Mississippian ages obtained by Kosminska et al., 2020 may very well represent deep, late Caledonian processes and are not representative of deformation at shallow-crustal levels, e.g., in Devonian rocks of the Andrée Land Group and Mimerdalen Subgroup). Furthermore, Dr. Piepjohn's structural field data do also support the model presented in the present manuscript (the trend and plunge of intepreted Ellesmerian structures are similar to those of Eurekan structures; this is further discussed in the reply to Dr. Piepjohn's comment 288), the interpreted cutting relationships used by Dr. Piepjohn (e.g., speculating that the contact between Lower-lowermost Upper Devonian rocks of the Andrée Land Group/Mimerdalen Subgroup and uppermost Devonian-Permian rocks of the Billefjorden and Gipsdalen groups is a non-tectonized stratigraphic unconformity everywhere in Spitsbergen) are based on highly questionable interpretations of distant observations of inaccessible and mostly covered outcrop transects (e.g., in Dickson Land; Figures 2-25), and the transport directions of Eurekan and Ellesmerian structures cannot be used as an argument to distinguish them from one another because of strain partitioning along WNW-ESE-striking, inherited Timanian faults (further discussed in the reply to Dr. Piepjohn's comment 62; Koehl, 2019a, 2019b, 2020). Comment 88: agreed. Comment 89: disagreed. Even if Dr. Rippington may have never visited the Triungen locality, his writings reflect well the idea the author of the present manuscript wants to convey to the reader: that the Triungen locality in central Spitsbergen has been used by many 
researchers (including Dr. Piepjohn) to support models of Ellesmerian deformation and to pin-point the timing of this tectonic event. Comment 90: disagreed. Dr. Piepjohn and most of the supporters of the Ellesmerian Orogeny use the argument of supposedly undeformed strata of the uppermost Devonian-Mississippian Billefjorden Group juxtaposed against or unconformably overlying folded Devonian strata of the Andrée Land Group and Mimerdalen Subgroup in localities like Triungen and Pyramiden to support their models. By showing that weak, coal- and coaly shale-rich strata of the Billefjorden Group are intensely deformed in key localities like Pyramiden (and possibly in Triungen as well), the present manuscript provides strong evidences of strain partitioning and decoupling during early Cenozoic Eurekan deformation and, hence, questions the occurrence of Ellesmerian deformation in Spitsbergen since this tectonic episode is poorly constrained from a geochronological perspective and poorly distinguished from Caledonian and/or Eurekan deformation both in Arctic Canada, northern Greenland and Svalbard. Comment 91: agreed. Comment 92: Dr. Piepjohn seems not to understand that there are, at present day, data of different types than just "field data" one may work with to investigate various structures in areas around the world without having to collect field data. Such data include but are not limited to: raw and tilt-derivative aeromagnetic data (used in Koehl, 2019a, 2019b, 2020 to infer the presence of Devonian core complexes throughout Spitsbergen), gravimetric data (used in Koehl, 2019a, 2019b, 2020) to infer the presence of a major top-SSW sinistral-reverse inherited Timanian thrust running from Kongsfjorden to Sassenfjorden and Storfjorden), seismic data (used in the present manuscript and in Koehl et al., in prep. a, to discuss strain partitioning and decoupling, and the presence of several levels of décollement throughout post-Caledonian sedimentary units in Spitsbergen; see also Figure 28), satellite images (used in the present manuscript and in Koehl et al., in prep. a, to illustrate the uncertainty around the interpretation of large outcrop transects mostly consisting of loose material and/or inaccessible for detailed outcrop study), petrological data (used in the present manuscript to discuss the presence of the Balliolbreen Fault in Pyramiden; see supplements), structural measurements and

Interactive comment
Printer-friendly version

Discussion paper

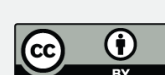


geological maps published in previous studies (published and, therefore, possible to use to reinterpretet structures and field relations and to support one's own discussion and conclusions even though these conclusions disagree with the conclusions of the author who acquired the data), and field photographs published in previous studies (though not any from Dr. Piepjohn's contributions about Ellesmerian tectonism in Svalbard) or unpublished (Figures 2-25). Comment 93: agreed. However, it is not the goal of figure $1 a-b$ in the manuscript to show structures, but rather to show the location of localities mentioned in the text. Rephrasing is therefore needed. Comment 94: agreed. However, the present manuscript uses the studies of Sartini-Rideout et al. (2006), Hallett et al. (2014) and McClelland et al. (2016) in northeastern Greenland not because they deal with Ellesmerian contraction, but because they document basement exhumation, possibly as core complexes, along Svalbard's conjugate margin in northeastern Greenland, i.e., adjacent to Spitsbergen prior to the opening of the Fram Strait. Comment 95: agreed. Comment 96: agreed. Comment 97: disagreed. Once again, Dr. Piepjohn does not take into account non field-based studies, e.g., by Kumar et al. (2011), suggesting Ellesmerian tectonism along the US part of the Chukcki Shelf. See reply to Dr. Piepjohn's comment 79 for further discussion. Comment 98: disagreed. See Lorenz et al. (2008) discussing Late Devonian-Mississippian contraction in Severnaya Zemlya. Comment 99: agreed. Transpression and transtension simply express strain partitioning along deformed margins. But strain partitioning may also affect margins deformed by orthogonal contraction and, thus, involved significant amounts of strike-slip movements (e.g., the west Spitsbergen margin in Caledonian and possibly Eurekan times), i.e., transpression/transtension. However, it is not the aim of the present manuscript to discuss these issues. Thus, the author uses contraction-transpression to satisfy all parties. Comment 100: Caledonian grain is present in Billefjorden, in basement rocks exposed in the eastern part of the area and that are part of the Atomfjella Antiform (Flood et al., 1969; Balashov et al., 1993; Witt-Nilsson et al., 1998; Johansson and Gee, 1999), and as close to the Billefjorden Fault Zone as Mittag-Lefflerbreen (Koehl and Muñoz-Barrera, 2018), i.e.,

Printer-friendly version

Discussion paper
Interactive

comment

\section{Discussion paper}

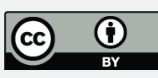


in (northeasternmost) central Spitsbergen. Comment 101: see reply to comment 100. Comment 102: agreed. However, such distinction is irrelevant in the scope of the present manuscript and would only further lengthen a manuscript already relatively long (as already pointed out by Dr. Piepjohn in his comment 11). Comment 103: agreed. Comment 104: agreed, which is why the "half-" is in parenthesis, to reflect the fact that there is a half-graben in Raudfjorden and graben in Bockfjorden. Comment 105: agreed. See reply to comment 104. Comment 106: Kota is a locality along the northeastern flank of Mudderbukta mentioned in Roy (2007; also possible to locate on toposvalbard.npolar.no by using the search field) showing Devonian low-angle normal faults within the Wood Bay Formation (Roy, 2007, see field photographs in his figure 23a-b). The manuscripts listed in appendix A (including the work by J.-C. Roy) should have been made available online and freely accessible to the scientific community, but time and budget constraints seem to have taken the best out of this initiative. The author of the present manuscript sincerely apologizes to the referees and all reader of the present discussion for this inconvenience. However, copies of these contributions will be made available as part of the Rock Vault Project at the University Center in Svalbard (www.svalbox.no/srv). In the meantime, any interested parties are very welcome to send an email at jean-baptiste.koehl@uit.no. Comment 107: agreed. Comment 108: agreed. However, this sentence is not referring to Eurekan (/Ellesmerian) (back-) thrusts but to top-east Devonian extensional detachments, e.g., Woodfjorden (Roy et al., unpublished) and Keisarhjelmen detachments (Braathen et al., 2018a). Comment 109: agreed. The Woodfjorden Detachment is located in western and southern Andrée Land and is also mentioned in Roy (2007, pp. 196). Comment 110: agreed. As mentioned by Dr. Piepjohn, east-verging folds do exist in Andrée Land. This is also illustrated in Chorowicz (1992), Roy $(2007,2009)$ and Roy et al. (unpublished). Comment 111: agreed. The author of the present manuscript has taken the matter into his own hands and spent tens of hours digitalizing thousands of pages of relatively old manuscripts about the geology of Svalbard that were rediscovered by chance by the author of the present manuscript in summer 2019

Interactive comment
Printer-friendly version

Discussion paper

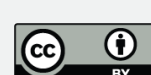


and are, at present day, still not available online. These manuscripts include quite a few manuscripts of Dr. Piepjohn's and his team about Ellesmerian contraction in Svalbard (e.g., Piepjohn, 1997b; Piepjohn and Thiedig, 1997a, 1997b; Piepjohn et al., 1997a, 1997b; Kempe et al., 1997; Michaelsen et al., 1997; Michaelsen, 1998). As mentioned earlier, these old manuscripts will be included in UNIS's Rock Vault Project in a near future. Comment 112: agreed. However, the author of the present manuscript would very much like to know what scientific evidences are used by "W. Dallmann pers. comm. 2009" (cited in Bergh et al., 2011 and Piepjohn and Dallmann, 2014) to question the Visean palynological ages obtained by Birkenmajer and Turnau (1962) for the base of the Adriabukta Formation, especially since these Visean ages actually seem to be robust (see reply to Dr. Piepjohn's comment 52 for further discussion around the age of the Adriabukta Formation). Comment 113: agreed. Comment 114: agreed. Comment 115: disagreed. Piepjohn and Dallmann (2014) argued that "The Mimerdalen Subgroup is probably the detrital fill of a small foreland basin derived from erosion during the uplift of the $\mathrm{Ny}$-Friesland Block to the east of the Billefjorden Fault Zone." Thus, it is clear that they argued that the Mimerdalen Subgroup (Planteryggen and Plantekløfta formations) was deposited during the onset of Ellesmerian deformation. Comment 116: disagreed. In the light of new and more accurate (than Schweitzer, 1999 and Piepjohn et al., 2000) paleontological and palynological dating by specialists and experts in paleontology/palynology of Middle-lowermost Upper Devonian rocks of the Mimerdalen Subgroup and uppermost Devonian-Mississippian strata of the Billefjorden Group (Scheibner et al., 2012; Lindeman et al., 2013; Berry and Marshall, 2015; Marshall et al., 2015; Newman et al., 2019; Lopes, pers. comm. 2019), it turns out that Ellesmerian deformation can only be pre-middle Famennian in age (i.e., prior to the deposition of the Billefjorden Group) no matter what age Dr. Piepjohn argued for in Piepjohn (2000). Comment 117: agreed. Dr. Piepjohn has already judged the present manuscript to "too long" (his comment 11) and to contain enough references (his comment 12), the author of the present manuscript does not see it fit to further crowd the manuscript with more references

Interactive comment 
since the studies cited in this sentence all cite the "other studies" Dr. Piepjohn is referring to. Comment 118: disagreed. The studies mentioned in this sentence were (to the author of the present manuscript's knowledge) the first ones to ever report the presence of Proterozoic basement rocks thrusted on top of Lower Devonian rocks at the Pyramiden locality, whereas older studies like Harland et al. (1974), Lamar et al. (1986) and Arktikugol (1988; Sirotkin pers. comm. 2019) do not show any Proterozoic basement in the outcrops below the mine entrance. The author of the present manuscript is still wondering what this change is based on and would eagerly discuss potential evidences. Comment 119: agreed. However, the reference is attached to "Ellesmerian contraction", not to what is written before this. Since Piepjohn (2000) is one of the most relevant contributions about Ellesmerian deformation in Dickson Land, the author of the present manuscript judges it is appropriate to cite it there. Comment 120: agreed. Comment 121: disagreed. According to Berry and Marshall (2015, especially in their supplement DR3) who are experts in palynology/paleontology, there is no room for discussion: the age published by Brinkmann, Grewing, Piepjohn and Dallmann is erroneous because it is based on the misidentification of (only one specimen of) Retispora lepidoshyta paleospore. Furthermore, the age of Brinkmann, Grewing, Piepjohn and Dallmann is the only one in disagreement with all the other studies in Devonian-Mississippian rocks in Spitsbergen by specialists in palynology, paleontology and paleobotany (Scheibner et al., 2012; Lindeman et al., 2013; Berry and Marshall, 2015; Marshall et al., 2015; Lopes et al., 2018a; Newman et al., 2019; Lopes, pers. comm. 2019). The author of the present manuscript is convinced that it is therefore not needed to lengthen the present manuscript with a discussion around an erroneous age. Comment 122: agreed. See reply to comment 120. In addition, the Berry and Marshall (2015) and Newman et al. (2019) references are not attached to the "lower Munindalen thrust", but to the "lower Frasnian" age. Comment 123: agreed. Comment 124: agreed. Comment 125: agreed. Comment 126: agreed. This sentence simply describes the geological situation in Triungen. Comment 127: agreed. Comment 128: The author of the present manuscript judges that it is important to

Printer-friendly version

Discussion paper
Interactive

comment

\section{Discussion paper}

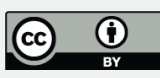


establish the geological situation in each key area he wishes to discuss later in the discussion. The present sentence has nothing to do with the "Mimerdalen/Munindalen area". Comment 129: partly agreed. The claim of Dr. Piepjohn that, based on structural similarities, fold structures in Andrée Land and Dickson Land are of the same age is justified. However, such a claim is not based on actual geochronological dating of thrusts and folds in Andrée Land interpreted as Ellesmerian. Thus, the timing inferred by Dr. Piepjohn based on structural similarities remains tentative. As shown in the present manuscript, fold and thrust structures in Dickson Land and Andrée Land are more likely to be early Cenozoic in age and/or partly Devonian extension-related structures. Comment 130: agreed. However, the reference (Bergh et al., 2011) is attached to "In southern Spitsbergen, in Hornsund (Error! Reference source not found.a), Ellesmerian folds and thrusts trend parallel to Cenozoic structures and verge towards the east", not to "Andrée Land". Also agreed that the sentence should refer to earlier works. Comment 131: agreed. However, due to the unavailability of the paper by von Gosen and Piepjohn (2001), the author of the present manuscript feels that it would be unethical to cite it without knowing its content. Perhaps Dr. Piepjohn and his co-workers may want to consider Gold (e.g., Solid Earth, Polar Research) or Diamond (Norwegian Journal of Geology) open-access journals for their future publications to ensure that these contributions are accessible by most scientists and, thus, possible to cite. Also agreed that the Mariekammen Shear Zone is not the main argument but one of the main arguments supporting Ellesmerian deformation in southern Spitsbergen. Comment 132: disagreed. See reply to comment 52. Comment 133: agreed. Unfortunately, the author of the present manuscript does not have access to Dr. Piepjohn's contribution (von Gosen and Piepjohn, 2001) and, therefore, cannot discuss the evidence it presents. Comment 134: agreed. Comment 135: agreed. Comment 136: agreed. Comment 137: agreed. Comment 138: agreed. Comment 139: agreed. However, this sentence states that Eurekan deformation "initiated" ca. $62 \mathrm{Ma}$ and, thus, is in agreement with Dr. Piepjohn's findings in northern Greenland. Comment 140: agreed. Comment 141: agreed. However, the Tessensohn et al. (2001) 
publication mentioned by Dr. Piepjohn was published in a journal that is not available to the author of the present manuscript and, therefore, cannot be cited. Comment 142: agreed. However, the present manuscript only cites the most recent structural mapping studies in Brøggerhalvøya. The author of the present manuscript does not believe that crowding the manuscript with even more references in this particular sentence would lead to a significant improvement. In addition, the author of the present manuscript is uncertain about which publication of Prof. Harland Dr. Piepjohn is referring to. Comment 143: disagreed. The present paper only deals with the Billefjorden Fault Zone and lengthening this particular sentence with "and the Lomfjorden Fault Zone" with associated references would only lengthen the manuscript and take it out of its scope. Comment 144: agreed. Comment 145: though Dr. Piepjohn's comment is a little imprecise, the author of the present manuscript agrees that this sentence might need rewriting. Comment 146: agreed. However, the von Gosen and Pipejohn (2001) reference suggested by Dr. Piepjohn is unavailable to the author of the present manuscript and will therefore not be added to the present manuscript. Comment 147: disagreed. See reply to comment 131. Comment 148: disagreed. Many workers have worked with the Pyramiden locality and came to significantly different conclusions in their mapping regarding the presence or not of Proterozoic basement rocks in outcrop below the entrance of the mine. Notably, old studies like Harland et al. (1974), Lamar et al. (1986) and Arktikugol (1988; Sirotkin, pers. comm. 2019) show no basement rocks in outcrop, whereas more recent studies (e.g., Piepjohn et al., 1997a; Piepjohn, 2000; Bergh et al., 2011) mapped basement rocks below the mine entrance. The present manuscript presents some piece of information that may help resolving this ambiguity. Comment 149: agreed. However, supplement 3 clearly demonstrate the locally overturned-to-the-east character of Devonian strata in the area (the location of overturned Devonian beds of supplement 3 are shown in figures 2 and $3 a$ in the manuscript). Comment 150: see reply to comment 149. Comment 151: disagreed. The present paragraph deals with the Pyramiden locality and has nothing to do with areas farther north. However, the author of the present manuscript agrees that "Hecla 
Hoek" is old-fashioned. Comment 152: agreed. Comment 153: agreed. However, the next three words of the sentence read "and Billefjorden Group", thus agreeing with Dr. Piepjohn's comment. Comment 154: agreed. The coal-rich units are most likely part of the Billefjorden Group. Comment 155: disagreed. The author of the present manuscript acknowledges his mistake in the following reference citation: McClay and Insley (1986) throughout the text. Comment 156: agreed. See reply to comment 154. Comment 157: disagreed. Using "hindward-dipping" to describe bedding-parallel duplexes within coal-rich strata of the Billefjorden Group in Pyramiden would be incorrect because the investigated east-dipping duplexes dip away from the West Spitsbergen Fold-and-Thrust Belt hinterland (located west/southwest of Pyramiden). Using "forward-dipping" would also be incorrect since the duplexes are dipping to the east, i.e., away from the foreland basin of the West Spitsbergen Fold-and-Thrust Belt (the Central Tertiary Basin, which is located in the southwest of Pyramiden). Thus, the nomenclature of Boyer and Elliott (1982) does not apply here. Comment 158: the author of the present manuscript wants to underline that he clearly described the uncertainty surrounding his interpretation of unfaulted contacts above the mine (based on partly covered and partly loose outcrops, though partly dug out). The author of the present manuscript does not wish to speculate on the nature of the contact between Devonian and uppermost Devonian-Mississippian rocks above the mine entrance in Pyramiden. Comment 159: disagreed. In an area known for its dominant strike of major N-S- to NNW-SSE-striking faults (e.g., the Balliolbreen Fault, Odellfjellet Fault, upper and lower Munindalen thrusts, Robertsonbreen thrust, and Løvehovden Fault), E-W- to WNW-ESE-trending outcrop transects should definitely be more prone to reflect the dominant N-S to NNW-SSE fault strike. This paragraph is necessary to the argumentation of the manuscript in showing that the author of the present manuscript has addressed potential uncertainties and biases regarding data acquisition and, thus, related to the model based on the data. Note that the description of such uncertainty is essentially lacking in most contribution about Ellesmerian deformation in Spitsbergen, but would be very useful to assess the likelyhood of such

Printer-friendly version

Discussion paper
Interactive comment

\section{Discussion paper}

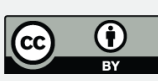


hypothesis. Comment 160: disagreed. Again, Dr. Piepjohn seems to assume that only fieldwork can solve geological problems. In this paragraph, the author of the present manuscript introduces the uncertainty related to field relationships in Triungen, something that contributions dealing with Ellesmerian deformation in this area should have included. The uncertainty mentioned in this paragraph is critical when discussing strain partitioning and decoupling in Triungen, and clearly shows that despite all the (field) work done in the area, it is probable that the resulting field geometries (folded Devonian west of the Triungen-Grønhorgdalen Fault Zone and flat-lying Devonian and uppermost Devonian-Mississippian rocks in the east) are related to Eurekan decoupling along décollements and bedding-parallel duplexes within coals of the Billefjorden Group. Furthermore, the oldest spores in the Triungen Member of the Billefjorden Group in Triungen are mid-Famennian (uppermost Devonian) in age (Marshall et al., 2015). Comment 161: agreed. The mentioned succession refers to Devonian rocks of the Andrée Land Group. Comment 162: disagreed. The fact that the Grey Hoek and Widje Bay formations are only exposed in northern Andrée Land does not constitute a counter-argument to their interpretation farther south on seismic data. It simply suggests a lower likelihood than, e.g., rocks of the Wood Bay Formation. The author of the present manuscript simply wants to be clear that since this paragraph is dealing with "seismic interpretation", there is uncertainty as to which shale-rich Devonian formation could be present in Reindalspasset. Potential candidate include the Wood Bay Formation and the Grey Hoek and Widje formations. Comment 163: agreed. Comment 164: agreed. Comment 165: agreed. Comment 166: agreed. Comment 167: agreed. Comment 168: agreed. Comment 169: agreed. Comment 170: agreed. Comment 171: agreed. Comment 172: disagreed. This sub-section deals with structures on seismic data, whereas the section mentioned by Dr. Piepjohn (line 394) deals with the seismic stratigraphy. Comment 173: disagreed. See reply to comment 162. Comment 174: agreed. However, Eide et al. (1991) wrote the completion report of exploration well 7816/12-1 that penetrated these décollements in Reindalspasset and, thus, are the first to ever mention these faults/décollements in this

Printer-friendly version

Discussion paper
Interactive comment

\section{Discussion paper}

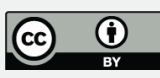


area. Hence, the author of the present manuscript does not judge necessary to add more references and lengthen the manuscript in this particular sentence since the most relevant reference is indeed Eide et al. (1991). Comment 175: agreed. Comment 176: agreed. Comment 177: agreed. Comment 178: disagreed. See reply to comments 41 and 43 about Dr. Piepjohn's tendency to assume that only fieldwork can solve geological problems, and see reply to comment 131 about the suggested von Gosen and Piepjohn (2001) reference. Comment 179: disagreed. Here is a crucial comment by Dr. Piepjohn showing his tendency to forget the distinction between "observation" and "interpretation", thus leading to his assumption that all interpretations based on field observations are truth. Unfortunately, unless the investigated outcrop extends several hundred meters to several kilometers in all directions ( $x, y, z$ axes) without being partly-mostly covered by loose material and being accessible everywhere for detailed outcrop inspection, field observations mostly lead to interpretations with various amounts of associated uncertainty. Despite being quite confident that the outcrop shown in figure $3 \mathrm{~b}$ in the manuscript represents "gently dipping duplexes comprised of interbedded coal-coaly shale and sandstone deposits with sigmoidal shear fabrics and (imbricate) link thrusts [...] connecting bedding-parallel décollements [...] localized along lithological boundaries", the author of the present manuscript refrains from calling it an "observation" as Dr. Piepjohn suggests. The author of the present manuscript is aware that despite the relatively good quality of outcrop exposures in Pyramiden, these may lead other workers to interpretations different from his. The author of the present manuscript does not pretend to know what lies below every single piece of screes/loose material in the study area and, hence, is aware that his interpretation might be proven wrong by subsequent (field and/or geophysical and/or petrological and/or microstructural and/or other) studies of the Pyramiden locality. The reader is referred to the paragraph lines 321-344 of the present manuscript to read about actual field observations at this particular outcrop, e.g., describing the attitude of bedding surfaces (trend and dip direction) and intra-bed fabrics. Comment 180: agreed. The Eurekan bedding-parallel duplexes and décollements within uppermost

Interactive comment
Printer-friendly version

Discussion paper 
Devonian-Mississippian coal-rich strata of the Billefjorden Group partitioned Eurekan deformation in Pyramiden, and if they did partition deformation in Pyramiden, it is very likely that analogous structures within contemporaneous stratigraphic units with comparable lithology did as much in various places in Spitsbergen. Other candidate localities notably include Triungen (and possibly other localities lie Adriabukta) where undeformed strata of the Billefjorden Group cropping out near folded Devonian rocks (Figures 15-25) were used by Dr. Piepjohn and his team to support the occurrence of Ellesmerian deformation. The author of the present manuscript would like to apologize for the "in preparation" status of the his work onshore Bjørnøya and added a field photograph of this ongoing work showing latest Devonian-Mississippian listric normal fault flattening downwards into a coal-rich bed acting as a décollement (i.e., partitioning-decoupling deformation like in Pyramiden and regionally in Spitsbergen) to the present discussion (Figure 32). Comment 181: agreed. Comment 182: agreed. Comment 183: agreed. The author of the present manuscript is a little uncertain whether to include or not manuscripts "in preparation" to the reference list, but is willing to do it should the editor and/or the team at Solid Earth require it. Comment 184: agreed. Comment 185: agreed. The sentence is poorly phrased. Comment 186: agreed. Comment 187: agreed. Comment 188: disagreed. See reply to comment 162. Comment 189: agreed. However, the comparison does not apply to the tectonic setting (structures in Pyramiden are not thought to be related to a subduction zone) but to the characteristic of duplexes in Sassenfjorden-Tempelfjorden on seismic data and their comparable geometry to duplex structures on seismic data in other studies. Comment 190: agreed. The author of the present manuscript has definitely "seen the structures in northern Andrée Land (Bravallafjella Fold Zone)" and "in Soerkapp Land (Rökensata)", which were published as actual field photographs in Dallmann and Piepjohn (submitted) and Dallmann (1992) respectively. Also agreed that the figure quality should be improved. Comment 191: disagreed. The only dangerous "ifs" are those untold of, like all those involved in Dr. Piepjohn and his team's field interpretation of indirect field observations supporting Ellesmerian deformation. The 
"ifs" involved in the model argued for in the present manuscript are well explained and may, thus, easily be invalidated by future studies. On the contrary, none of Dr. Piepjohn's field studies actually mentions or discusses the degree of uncertainty associated to their interpretation of field observations and of large outcrop transects mostly consisting of loose material and essentially inaccessible for detailed outcrop study (e.g., Figures 2-25). The present manuscript and present discussion fill up this gap by showing the high amount of uncertainty involved in Dr. Piepjohn's and other pro-Ellesmerian workers' interpretations and models, which (by the way) rarely include any field photographs as supporting evidence (despite being field studies) and only include idealized conceptual sketches. Comment 192: Dr. Piepjohn has been given access to the studies mentioning these structures. Comment 193: agreed. Comment 194: agreed. Comment 195: the interpretation (not observation) that "Cenozoic deformation in Svalbard is dominated by "'contractional-transpressional" structures" is based on all previous works that have already been mentioned in the 'introduction' and 'geological setting' chapters. Thus, it is not relevant to lengthen the manuscript anymore by adding these references again. As mentioned earlier, the description of deformation episodes as discrete phases is old-fashioned (e.g., Fossen, 2020; see reply to comment 87 for further discussion) since structures with different attitudes and trends tend to form synchronously, especially in areas where strain partitioning and decoupling is common like Spitsbergen (Maher et al., 1997; Braathen et al., 1999a, 1999b; Bergh et al., 2000; Leever et al., 2011a, 2011b; present manuscript; Koehl et al., in prep. a; Figure 28). Again, the present paper does not aim at distinguishing between contraction and transpression. Comment 196: disagreed. The author of the present manuscript is not the first one to mention "the Cenozoic contractional deformation in post-Andrée Land Group deposits between the areas of the WSFTB and the BFZ and LFZ". However, the author of the present manuscript is the first one to focus on bedding-parallel duplexes and décollements within coals and shales of the Billefjorden Group in central Spitsbergen as mentioned in this sentence. Comment 197: agreed. However, the author of the present manuscript does not refer to his

Printer-friendly version

Discussion paper
Interactive comment

\section{Discussion paper}

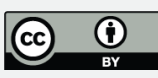


own work in this sentence and prefers to only mention the most two relevant studies about the coal-rich beds in Pyramiden, i.e., Livshits (1966) and Cutbill et al. (1976) in an effort to keep the length of the manuscript as reduced as possible, which was also suggested by Dr. Piepjohn in his comment 11. Perhaps Dr. Piepjohn may want to specify which reference he would recommend to include. Comment 198: agreed. Comment 199: yes, it is (e.g., Larssen et al., 2002; Lopes et al., 2018b). Comment 200: agreed. There is a number of previous workers that have worked with the geology of the Billefjorden Group before the author of the previous manuscript. Some of the previous workers mentioned by Dr. Piepjohn suggested syn-tectonic deposition based on sedimentological evidence (e.g., Aakvik, 1981; Gjelberg, 1984) and on the presence of soft-sediment deformation structures on Bjørnøya (Worsley et al., 2001), but none of them provided clear evidence (e.g., potential growth strata associated to adjacent normal faults) of syn-extension/syn-tectonic deposition for these sedimentary strata like Koehl and Muñoz-Barrera (2018, their figure $8 \mathrm{~b}$ and c) in Odellfjellet or like Koehl et al. (2018, their figures 5 and 6) in the Barents Sea. Hence, these references are the most relevant works to illustrate the argumentation in this paragraph. Note that previous workers like Cutbill and Challinor (1965), Cutbill et al. (1976), Gjelberg and Steel (1981), Gjelberg (1981, 1984), Bugge et al. (1995), Larssen et al. (2002) were extensively acknowledged in the "geological setting" section. Reference about the work of Aakvik (1981) will be added. Comment 201: agreed. However, as addressed in the present manuscript, actual field/outcrop evidence (not from the distance) do not suggest the presence of any major structure in Pyramiden (see also section 5.1.3 for discussion about the presence of the Balliolbreen Fault in Pyramiden). Comment 202: agreed. Regarding the "kilometer-scale fold-structures of the Dicksonland Fold-and-Thrust Zone directly west of the BFZ in central Dickson Land", these may have partly formed through extensional detachment-related folding (e.g., Chorowicz, 1992; Roy, 2007, 2009; Roy et al., unpublished; Braathen et al., 2020), i.e., enough to generate tilting of Devonian strata (e.g., through normal faulting) and an unconformity with overlying uppermost Devonian-Mississippian strata, and 
partly during early Cenozoic Eurekan deformation due to strain partitioning and decoupling. The claim of Dr. Piepjohn that these folds are "unconformably overlain by deposits of the Billefjorden Group along a high-angle unconformity" is not verifiable since (1) his 1996 map is not accessible, (2) he has not published any field photograph supporting his claim, (3) the unconformity between Devonian rocks of the Andrée Land Group/Mimerdalen Subgroup and uppermost Devonian-Mississippian rocks of the Billefjorden Group is limited in extent (because of the erosion or non-deposition of the Billefjorden Group) and partly covered and mostly inaccessible to physically visit for close inspection to make sure that the unconformity is not tectonized (e.g., like in Pyramiden). In addition, the present manuscript does not argue for a regional décollement level between Devonian and uppermost Devonian-Mississippian rocks, but for local décollements in the very few places where Devonian rocks of the Andrée Land Group and Mimerdalen Subgroup are tightly folded below post-Devonian rocks. In most places, Devonian rocks are only tilted or very gently folded, which may very well be explained by extensional detachment faulting and/or normal faulting (e.g., Chorowicz, 1992; Roy, 2007, 2009; Roy et al., unpublished). Furthermore, in the case of a regional décollement structure as mentioned by Dr. Piepjohn, it is not certain that such a structure would be visible if it were covered by loose material/screes and was inaccessible for detailed outcrop characterization because located in steep slopes and unstable cliff outcrops. Comment 203: agreed. However, the argument used to "eliminate the Ellesmerian", is not that "Devonian deposits maybe party affected by the Eurekan deformation", but that the contact between these deposits and strata of the Billefjorden and Gipsdalen groups are, in places, tectonized (e.g., duplexes, thrusts and décollements) and, thus, that all the fold and thrust structures within deposits of the Andrée Land Group and Mimerdalen Subgroup can be explained much more easily by a combination of extensional detachment folding and/or normal faulting block-tilting (well known in this area; McCann, 2000; Koehl et al., in prep. a; Figure 28) and strain partitioning and decoupling during Eurekan deformation (Koehl, 2019a, 2019b, 2020; present manuscript; Koehl et al., in prep. a; Figure 28) than by adding

Interactive comment
Printer-friendly version

Discussion paper

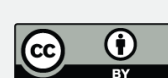


a full orogenic cycle like the Ellesmerian Orogeny. In his comment 202, Dr. Piepjohn mentions that his "1:10.000 scale mapping of central Dickson Land in 1996 has shown that the base of the Billefjorden Group on top of the deformation Devonian rocks is sedimentary" to argue against the presence of décollements between Devonian strata of the Andrée Land Group/Mimerdalen Subgroup and of the Billefjorden Group in Dickson Land. First, the present manuscript does not dispute that the contact between strata of Andrée Land Group/Mimerdalen Subgroup and the Billefjorden Group may locally be an unconformity (and might have been an unconformity everywhere prior to Eurekan deformation). Second, the fact that an unconformity (most likely arising from tilting related to normal block-faulting; e.g., Koehl et al., in prep. a; Figure 28; and from detachment folding during Devonian collapse-related extension; Chorowicz, 1992; Roy, 2007, 2009; Roy et al., unpublished; Braathen et al., 2018a, 2020) is preserved between rocks of the Andrée Land Group/Mimerdalen Subgroup and rocks of the Billefjorden Group does not disprove the local presence of duplexes and décollements at the base of the latter, especially if the evidence of an (non-tectonized) unconformity mentioned by Dr. Piepjohn are based exclusively on distant field observations of partly-mostly covered (by screes) and physically inaccessible outcrops (e.g., Figures 2-25). Outcrops like those in Pyramiden (figure 3b in the present manuscript) suggest that the contact between rocks of the Andrée Land Group/Mimerdalen Subgroup and rocks of the Billefjorden Group (regardless of whether initially an unconformity or conformity) was tectonically reworked during Eurekan deformation and, thus, might have equally been reworked elsewhere, e.g., in Triungen where the presence of a local décollement in tectonically thickened uppermost Devonian-Mississippian coals is supported by the presence of coal screes along the covered Triungen-Grønhorgdalen Fault Zone (e.g., figure 3c in the present manuscript and Figures 20-22). Evidences of early Cenozoic strain partitioning and decoupling between Devonian rocks of the Andrée Land Group/Mimerdalen Subgroup and uppermost Devonian-Permian strata (Billefjorden Group and Wordiekammen Formation) in Dickson Land (present manuscript; Koehl et al., in prep. a; Figure 28) call for a reexamination of every

Interactive comment

Printer-friendly version

Discussion paper

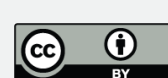


evidence presumably supporting the occurrence of Ellesmerian deformation, and (re-) assessment of the uncertainty associated to these evidences. Such a reexamination is attempted in the present manuscript (sections 5.2, 5.3 and 5.4). Discussion and reinterpretation (based on data from the present manuscript and from existing literature, e.g., Chorowicz, 1992; Piepjohn, 1994, 2000; Piepjohn et al., 1997a; Michaelsen, 1998; Roy, 2007, 2009; Roy et al., unpublished; Braathen et al., 2018a, 2020) of these evidences suggest that Ellesmerian deformation is not needed to explain any of the structures interpreted to be Ellesmerian, and that each of these structures may be easily reinterpreted as the product of Devonian post-Caledonian extension (including detachment folding, normal fault block tilting, and/or core complex exhumation) and/or Eurekan strain partitioning and decoupling by using the data and observations previous authors used to support their Ellesmerian age and/or by highlighting the high degree of uncertainty surrounding these data and interpretations (e.g., Piepjohn et al., 1997a, 2000; Michaelsen et al., 1997; Michaelsen, 1998; Piepjohn, 2000) and/or by showing the lack of discussion of other scenario (e.g., Kosminska et al., 2017; Majka and Kosminska, 2017; Schneider et al., 2018). Comment 204: agreed. Comment 205: agreed. Comment 206: disagreed. The backward-dipping duplexes and décollements in the Zagros Fold-and-Thrust Belt are similar to those observed in Pyramiden (see Costa and Vendeville, 2002, their figure 5; Bahroudi and Koyi, 2003, their figure 8; Fard et al., 2006, their figure 17). The author of the previous manuscript has only seen idealized/conceptual sketches and maps (no actual field photographs) by Dallmann and Piepjohn (submitted) of the "Nidedalen, Garmdalen and Alvrekdalen" area. However, the author of the present manuscript has indeed studied seismic data adjacent to these areas in Billefjorden (Koehl et al., in prep. a; Figure 28), which clearly suggest the presence of décollement between the Wood Bay and Wordiekammen formations (see also Figure 28 and Figure 29). As mentioned earlier, seismic data provide users with more (laterally and vertically) continuous data than partly covered and partly inaccessible outcrop transects studied by Dr. Piepjohn in the "Nidedalen, Garmdalen and Alvrekdalen" area. Comment 207: agreed. The

Interactive comment
Printer-friendly version

Discussion paper

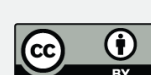


present manuscript discusses evidence that suggest that the Balliolbreen Fault is not present in Pyramiden, at least not at the location described by Harland et al. (1974) and subsequent workers. This sentence simply mentions the implication of findings discussed in section 5.1.2 on models discussed in section 5.1.3. Comment 208: disagreed. In this paragraph, the model discussed involves Carboniferous normal faulting, not Ellesmerian deformation. Evidences supporting Ellesmerian deformation were discussed extensively in previous studies by Dr. Piepjohn and other workers and are discussed with a different perspective in the present manuscript. Comment 209: partly agreed. The sentence is poorly written. However, based on Dr. Piepjohn's argument, every set of fold structures in a given stratigraphic interval is best explained by adding a new orogeny/episode of contraction-transpression to the geological history of a whole region. The author of the present manuscript disagrees with this and argues in the present manuscript that these folds are best explained by Devonian extensional detachment folding and normal faulting and tilting, and subsequent early Cenozoic strain partitioning and decoupling of Eurekan deformation. Comment 210: agreed. Comment 211: agreed. As it turns out, Dr. Jean-Claude Roy (Roy, 2007, 2009; Roy et al., unpublished) also agrees with Chorowicz (1992), and the former author published actual field photgraphs in James I Land (in Roy, 2007), e.g., of moderate-low-angle normal faults (detachments?) with associated bedding-parallel décollements (his figure 75) and fold structures related to slumps during extensional collapse in Lower-lowermost Upper Devonian sedimentary rocks of the Andrée Land Group/Mimerdalen Subgroup. Comment 212: agreed, though the Woodfjorden detachment is described in Roy $(2007,2009)$ and Roy et al. (unpublished) to which Dr. Piepjohn was given access. These publications (including Roy et al., unpublished) are available on request at the Norwegian Polar Institute Library in Tromsø, Norway. Comment 213: partly agreed. In this comment, Dr. Piepjohn acknowledges that the argumentation that all potential Ellesmerian structures in Andrée Land may be reinterpreted as extensional collapse-related structures is reasonable. However, the author of the present manuscript does not agree with Dr. Piepjohn when he suggests

Interactive comment
Printer-friendly version

Discussion paper

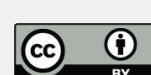


that the present manuscript ignores "all [the] structural works and publications" and contractional structures in "Mitrahalvoeya, Blomstrandhalvoeya". Structures in these areas are dealt with in section 5.2, lines 1046-1076 and are, as well, easily reinterpreted as early Cenozoic Eurekan thrusts since the only arguments used for infer an Ellesmerian age are (1) their west-verging character (which are, according to ongoing work by the author of the present manuscript, imputable to strain partitioning by a hundreds of kilometer-long Timanian thrust reactivated during Eurekan deformation; Koehl, 2019a, 2019b, 2020; Koehl et al., in prep. b) and (2) highly uncertain field relationships and one poorly preserved Conodont assemblages (Buggisch et al., 1994). Comment 214: new field evidence from the present manuscript, including the presence of a relatively small and thin, bedding-parallel cataclastic fault zone below the entrance of the Pyramiden mine, suggest that the Balliolbreen Fault is not present or not cropping out below the mine entrance in Pyramiden. If such a fault (inferred to be an Ellesmerian thrusts by Dr. Piepjohn and other, e.g., Harland et al., 1974) was present in Pyramiden, one would be able to see, e.g., (1) Proterozoic basement thrusted over Devonian rocks of the Andrée Land Group/Mimerdalen Subgroup, and/or (2) a major zone with brittle and/or ductile deformation truncating Devonian beds at a moderate-high-angle, and/or (3) uppermost Devonian-Mississippian strata deposited unconformably over a major thrust fault and/or (4) major disruptions of the stratigraphy of Devonian rocks of the Andrée Land Group/Mimerdalen Subgroup across the trace of the fault mapped, e.g., by Harland et al. (1974). None of these were observed in Pyramiden since the zone of brittle deformation is relatively small, does not appear to have accommodated significant movements, show Devonian rocks of the Andrée Land Group/Mimerdalen Subgroup in both footwall and hanging wall, and no Proterozoic basement was observed in Pyramiden. Thus, it is believed that the minor cataclastic, bedding-parallel fault zone (which is parallel to bedding surfaces displaying dominantly steeply east-dipping attitudes similar to those of uppermost Devonian-Mississippian bedding surfaces of the Billefjorden Group involved in early Cenozoic duplexes and décollements) formed as a minor bedding-parallel early

Printer-friendly version

Discussion paper
Interactive comment

\section{Discussion paper}

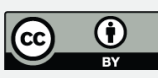


Cenozoic thrust fault and that the Balliolbreen does not crop out in Pyramiden (or is not present at all, even at depth). Comment 215: agreed. However, description of the seismic stratigraphy is used to argue for the presence of sedimentary units analogous to those of the Wood Bay Formation (and/or Grey Hoek and Widje formations) east of the Billefjorden Fault Zone in Reindalspasset (see sections 4.2.1 and 4.2.3). In addition, if the small $\mathrm{N}-\mathrm{S}$-striking brittle fault below the mine entrance in Pyramiden does indeed represent the Balliolbreen Fault (or a related overprint of this fault), as suggested by previous studies like Harland et al. (1974) and many other workers, then field mapping in Pyramiden does also suggest the presence of Devonian rocks of the Andrée Land Group/Mimerdalen Subgroup east of the Balliolbreen Fault (see figure 2 in the present manuscript). Comment 216: agreed. Comment 217: agreed. However, the present manuscript does not aim at discussing the uncertainty around the core complex model of Braathen et al. (2018a), which is already addressed by Dallmann and Piepjohn (2018) in their comments to Braathen et al. (2018a) and by Braathen et al. (2018b) in their reply to these comments. In addition, it is unnecessary to add a full orogenic cycle (Ellesmerian Orogeny) to explain erosion of Devonian strata of the Andrée Land Group/Mimerdalen Subgroup on a well known Caledonian ridge/fold structure/antiformal thrust stack east of the Billefjorden Fault Zone, the Atomfjella Antiform (e.g., Gee et al., 1994; Witt-Nilsson et al., 1998). Erosion may be explained simply with Devonian-Mississippian normal downthrowing to the west and/or through erosion of major highs due to major eustatic sea level fall as suggested for the late Frasnian-early Famennian (Sandberg et al., 2002). Regarding the presence of several core complexes, the Eolussletta Shear Zone (also called the Veteranen Line in Harland et al., 1992, and Sorgfjorden Shear Zone in Lyberis and Manby, 1993) displays down-east normal sense of shear (Gee et al., 1994, their figure 3; Johansson and Gee, 1999, their figure 2) and formed under greenschist facies conditions (Manby and Lyberis, 1991). Thus, although the Atomfjella Antiform does bear the marks of the Caledonian grain, this structure could have been exhumed as a core complex by the Eolusletta shear zone, in a similar scenario as proposed for the

Interactive comment
Printer-friendly version

Discussion paper

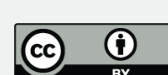


Keisarhjelmen Detachment in northwestern Spitsbergen (Braathen et al., 2018a). The Eolussletta Shear zone juxtaposes Tonian-early Cryogenian very low metamorphic facies rocks of the Veteranen Group (Lomfjorden Supergroup) in the hanging wall against Paleoproterozoic-earliest Neoproterozoic upper amphibolite facies rocks of the Planetfjella (Mosselhalvøya) Group and Atomfjella (Antiform) Complex in the footwall (Gee et al., 1994; Witt-Nilsson et al., 1998; Dallmann, 2015), which is typical of core complex-related shear zones (Snoke, 1980; Lister and Davis, 1989; Beaudouin et al., 2015; Yin et al., 2017). The author of the present manuscript further argues that the presence of several Devonian-Mississippian core complexes in Svalbard should not come as much of a surprise since such structures are well documented along the Norwegian continental shelf (e.g., Norton, 1987; Eide et al., 1999; Braathen et al., 2000; Osmundsen et al., 2005). The interpretation of Dr. Piepjohn that the contact between Devonian rocks of the Andrée Land Group/Mimerdalen Subgroup and uppermost Devonian-Mississippian rocks of the Billefjorden Group in Mimerdalen is tentative at most because it is based on distant observations of partly-mostly covered (by screes) and inaccessible outcrops (Figures 2-25). This contact is shown in the present manuscript's figure $3 \mathrm{~b}$ to be intensely tectonized into backward-dipping contractional duplexes and associated thrusts and bedding-parallel décollements. Combining these field and seismic evidences of this tectonized contact (figures $3 \mathrm{~b}$ and $4 \mathrm{~b}$ and $\mathrm{g}$ in the present manuscript) and widespread evidences for Eurekan strain partitioning in Billefjorden (Koehl et al., in prep. a; Figure 28), SassenfjordenTempelfjorden, Pyramiden (present manuscript), and throughout Spitsbergen (Harland et al., 1988; Ringset and Andresen, 1988; Maher et al., 1997; Braathen et al., 1999a, 1999b; Bergh et al., 2000; Braathen et al., 2011, e.g. their figure 7c; Leever et al., 2011a, 2011b), fold structures within Lower-lowermost Upper Devonian rocks of the Andrée Land Group and Mimerdalen Subgroup do not necessarily require an episode of contractional-transpressional deformation in the latest Devonian to have initiated, and may simply have formed due to combined Devonian extension and early Cenozoic Eurekan deformation. In this comment, Dr. Piepjohn acknowledges that 
Devonian sedimentary rocks of the Andrée Land Group may have been deposited east of the Billefjorden Fault Zone. Thus, it is conceivable that, in places (such as Reindalspasset), such sedimentary rocks were preserved. This is notably possible in Reindalspasset because the locality is located in the footwall of a major, hundreds of kilometer-long, top-SSW, Timanian thrust (extending from Kongsfjorden to Sassenfjorden, to Storfjorden, and further east in the northern Barents Sea) that was reactivated and accommodated kilometer-scale top-SSW movement in the early Cenozoic (Koehl, 2019a, 2019b, 2020; Koehl et al., in prep. b), thus potentially preserving Devonian sedimentary rocks of the Andrée Land Group deposited east of the Billefjorden Fault Zone in southern Spitsbergen as shown in figure $4 \mathrm{~g}$ in the present manuscript. Comment 218: agreed. However, this sentence is important to keep as such to properly illustrate the point made in this paragraph, i.e., that the various kinematics, geometries, etc. of the Balliolbreen Fault strongly suggest along strike segmentation. Comment 219: agreed. Comment 220: agreed. Comment 221: agreed. Comment 222: agreed. Comment 223: agreed. The faults in Sassenfjorden are shown in figure $4 a$ and $b$ in the manuscript. The other WNW-ESE-striking faults in Billefjorden are part of the study of Koehl et al. (in prep. a) and are not included in the present manuscript. These faults are shown in Koehl (2019a, pp. 90) and in Figure 28 (that is part of Koehl et al., in prep. a). Comment 224: agreed. It "may be explained by transpression", of which strain partitioning (including decoupling) is a very common process. Again, the present manuscript is careful in its interpretation and argumentation, leaving room for future discussion and different models and interpretations to be proposed. Comment 225: agreed. The main point of this figure is to show that one cannot see much at the Triungen locality, even in the field (also see Figures 15-25). However, what one can definitely see is the presence of black screes along the mapped trace of the Triungen-Grønhorgdalen Fault Zone, which therefore suggests the presence of abundant (thickened) coals of the Billefjorden Group along the fault and, hence, a high potential for (partial) decoupling as observed at the Pyramiden locality (figure $3 \mathrm{~b}$ in the present manuscript). Comment 226: disagreed. The author of the present

Interactive comment
Printer-friendly version

Discussion paper

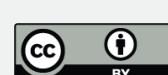


manuscript does not dispute the fact that the base of the Triungen Member of the Billefjorden Group in Triungen is, in most places, an undeformed unconformity (plain green line in figure $3 c$ in the present manuscript), which is even visible on the satellite image attached in the present manuscript 200-300 meters east of the trace of the Triungen-Grønhorgdalen Fault Zone. However, the key observation is, again, that this unconformity is mostly covered in this area, especially along the fault trace where the presence of abundant black screes strongly suggest the presence of thick coals of the Billefjorden Group, and since this area was indeed potentially subjected to intense Eurekan deformation as supported by top-WNW thrusting and coal-seated duplexes and décollements in Pyramiden (figure $3 \mathrm{~b}$ in the present manuscript), it is therefore highly likely that the coals along the Triungen-Grønhorgdalen Fault Zone also accommodated similar deformation and, thus, partially decoupled folded Lower Devonian rocks (west of the fault) from undeformed (flat-lying) Lower Devonian and uppermost Devonian-Permian strata (east of the fault) in Triungen. The main point of the present manuscript is not to argue that the contact between the Andrée Land Group/Mimerdalen Subgroup and overlying Billefjorden Group and/or Wordiekammen Formation is a regional décollement level, but that these stratigraphic boundaries are locally tectonized and affected by bedding-parallel décollements at key places and localities where they are partly covered and/or inaccessible to physically approach (only observed from great distance) and were used to infer Ellesmerian tectonism. The present manuscript discusses the uncertainty involved in the interpretation of each outcrop and dataset and, thus, involved in the model presented, and, as well, the uncertainty involved in the interpretation of Ellesmerian tectonism, which was yet to be addressed since previous studies (e.g., Piepjohn et al., 1997a; Piepjohn, 2000) seem to consider regional interpretations based on distant observation of poorly exposed and discontinuous outcrops almost as facts. Comment 227: disagreed. Once again, Dr. Piepjohn seems to consider that only fieldwork can resolve geological problems, which we now know is not the case. The Triungen and Pyramiden localities show many similarities, including the presence of a major east-dipping brittle fault 
(the Triungen-Grønhorgdalen Fault Zone in Triungen, and the Balliolbreen Fault in Pyramiden), contemporaneous deposits in the footwall (Wood Bay Formation) and hanging wall of the faults (Wood Bay Formation overlain by the Billefjorden Group, overlain by undeformed-tilted Pennsylvanian-Permian strata), and the presence of thickened uppermost Devonian-Mississippian coal along the fault (certain in Pyramiden, highly probable in Triungen). These similar situations (apart from the strongly sheared coals) are supported by Dr. Piepjohn's structural maps in these areas, e.g., in Piepjohn et al. (1997a, their figure 4) and Piepjohn (2000, his figure 3). The trace of the Triungen-Grønhorgdalen Fault Zone is completely covered by screes and loose material. The present manuscript uses the Pyramiden locality to argue that there are great chances that the covered fault trace in Triungen may also involves similar structures (coal-seated bedding-parallel duplexes and décollements) and processes (partial strain decoupling in early Cenozoic times) as in Pyramiden, and, thus, that adding an extra episode of deformation in the latest Devonian-Mississippian is not needed to explain field relationships and structures in Triungen. Comment 228: agreed. The present manuscript shows that there could be other valid interpretations than the one(s) presented in the manuscript (even that of Ellesmerian deformation), and aims at generating further debate and studies. The author of the present manuscript does not pretend to hold the exclusive rights to the ultimate truth. The model of the Ellesmerian Orogeny remained unquestioned/unchallenged for about 15 years (more?) but still does not provide satisfactory answers to many geological structures in Spitsbergen. The present manuscript simply aims at questioning models like that of the Ellesmerian Orogeny by showing that there are other models (e.g., combination of post-Caledonian extensional collapse and detachment folding, and early Cenozoic strain partitioning and decoupling) that may explain more simply (without adding an extra episode of tectonism, which time contraints show major inconsistencies; e.g., Visean-Serpukhovian southern Spitsbergen - Birkenmajer and Turnau, 1962 - and Late Devonian in central Spitsbergen - Lindemann et al., 2013; Berry and Marshall, 2015; Marshall et al., 2015; Newman et al., 2019) geological

Interactive comment
Printer-friendly version

Discussion paper 
relationships and observations on various datasets (not only field data) in Spitsbergen. The present manuscript shows (e.g., in the last paragraph of the conclusion, and through describing the amount of uncertainty associated to field interpretations) that there is much left to do to resolve the Late Devonian-Mississippian tectonic history of Spitsbergen and to conclude whether it involved Ellesmerian deformation or not. Comment 229: agreed. Dr. Piepjohn acknowledges the "presence of coal seams and coaly shales [...] at Triungen at the base of the Billefjorden Group above the tilted Devonian", thus supporting our interpretation. The author of the present manuscript also agrees with Dr. Piepjohn that "There is post-Ellesmerian deformation along the Groenhorgdalen-Triungen Fault", which also supports our interpretation of the possible occurrence of Eurekan structures (e.g., bedding-parallel duplexes and décollements) similar to the Pyramiden locality within the coals along the Triungen-Grønhorgdalen Fault Zone, i.e., partially decoupling Eurekan deformation between folded/tilted Lower Devonian strata and flat-lying uppermost Devonian-Permian strata of the Billefjorden and Gipsdalen groups. Comment 230: agreed. Comment 231: agreed. Comment 232: disagreed. The author of the present manuscript has indeed seen these outcrops in figure 53 in Michaelsen (1998), a student thesis that is not available online and only accessible by physically visiting the library of the Norwegian Polar Institute in Troms $\varnothing$ in northern Norway. This study is one of the only studies arguying for Ellesmerian deformation in Svalbard of Dr. Piepjohn's research group that actually shows field photographs to support their interpretation. The author of the present manuscript has also access to many field photographs in Dickson Land (see Figures 2-25), which clearly show that the idealized conceptual sketches of Dr. Piepjohn and his team in Mimerdalen and Munindalen involve a significant amounts of uncertainty because the outcrops (especially the contacts between Devonian rocks of the Andrée Land Group/Mimerdalen Subgroup and overlying rocks of the Billefjorden and Gipsdalen groups) are mostly inaccessible because located of very steep slopes and are mostly covered by screes and consist mostly of loose material (i.e., much less reliable than actual detailed outcrop studies provided in the present manuscript, e.g., in figures

Printer-friendly version

Discussion paper
Interactive comment

\section{Discussion paper}

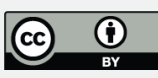


2, and $3 a$ and b). Figure 53 in Michaelsen (1998) is a field photograph of a steep transect of partly covered and partly inaccessible (because too steep) outcrops documenting a highly questionable interpretation that was also used by Dr. Piepjohn in his interpretations, idealized sketches and models of Ellesmerian deformation in Dickson Land. The interpretation is the following: the partly (-completely?) covered (by screes), moderate-low-angle boundary between green sandstones of the relatively old Austfjorden Member of the Wood Bay Formation with overlying, relatively younger red siltstones of the Dicksonfjorden Member of the Wood Bay Formation, which are both unconformably covered by flat-lying strata of the Wordiekammen Formation should be an Ellesmerian thrust, the upper Munindalen thrust. However, if a fault is actually present between these two stratigraphic unit, basic principles in structural geology tend to suggest that a fault juxtaposing relatively young material in the hanging wall against old material in the footwall is a normal fault (i.e., definitely not an Ellesmerian thrust), even though Dr. Piepjohn and his team possibly observed kinematic indicators at the bottom of the valley suggesting a possible Eurekan inversion of this fault. Considering the moderate-low-angle of this (speculated because partly-completely covered) fault and its normal (down-east) kinematics, it would be natural to suggest that it represents a low-angle Devonian extensional detachment, which is supported by the presence of analogous structures in Andrée Land (Woodfjorden Detachment; Roy, 2007, 2009; Roy et al., unpublished), in James I Land (Roy, 2007), and in northwestern Spitsbergen (Keisarhjelmen Detachment; Braathen et al., 2018a, 2020). Another possible reinterpretation is that there is no fault at all since the boundary between the two tilted stratigraphic units is partly-completely covered by screes/loose material and mostly inaccessible because located on steep cliff outcrops (see figure 53 in Michaelsen, 1998). Causes of the eastwards tilting of these Lower Devonian strata might, of course, be any episode of contraction one may add between the Early Devonian and the latest Carboniferous. However, since post-Caledonian extensional collapse was well documented during the Early Devonian (e.g., Manby and Lyberis, 1992), it is much more likely that such tilting was the result of, e.g., 
extensional detachment faulting and/or core complex exhumation and/or normal faulting (Chorowicz, 1992; McCann, 2000; Roy, 2007, 2009; Roy et al., unpublished; Braathen et al., 2018a, 2020). The author of the present manuscript argues that the interpretation of faults at the boundary between the Dicksonfjorden and Austfjorden members of the Wood Bay Formation is, at best, speculative since the boundary is essentially partly to completely covered and located on steep and inaccessible slopes (see figure 53 in Michaelsen) and since not hard evidence is provided in Michaelsen (1998) or any of Dr. Piepjohn's studies. In addition, the interpretation of these speculated faults as Ellesmerian thrusts is even more questionable since it denies basic principles in structural geology (reverse faults juxtapose old rocks over young rocks, which is definitely not the case for the upper Munindalen thrust). Thus, it does not matter how many "structural observations [the author of the present manuscript has] made in this area" (Dr. Piepjohn's comment 232), the interpretation of Michaelsen (1998) and, thus, every model of Ellesmerian deformation of Dr. Piepjohn in Dickson Land based on Michaelsen's data and highly doubtful interpretations are erroneous. Furthermore, the author of the present manuscript agrees with Dr. Piepjohn in that "The unconformity of the Wordiekammen Fm in this area is NOT a low-angle normal fault" (Dr. Piepjohn's comment 232) and it is not the aim of the present manuscript to argue for such interpretation. The present manuscript simply argues (like Koehl et al., in prep. a, as shown in Figure 28) that the unconformity between Devonian rocks and the Wordiekammen Formation may, in places, be tectonized and locally host bedding-parallel décollements (especially in places where the unconformity is almost completely covered by grey screes and was used by Dr. Piepjohn and his team to infer the occurrence of Ellesmerian deformation, e.g., figures 39 and 53 in Michaelsen, 1998 and Figures 2-25). The author of the present manuscript would like to let Dr. Piepjohn know that he has "seen the contacts of the Wordiekammen Fm [...] on top of the folded Devonian" (Dr. Piepjohn's comment 232) in figure 39 (actual field photograph) in Michaelsen (1998) and even provide field photographs of this poorly exposed contact in Dickson Land (Figures 2-25). Michaelsen (1998)'s

Interactive comment
Printer-friendly version

Discussion paper

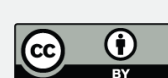


figure 39, once again, shows a steep cliff-outcrop transect (i.e., inaccessible by foot) of mostly loose material and screes based on which Michaelsen (1998, her figure 40) infers the presence of tight NW-verging folds within Lower Devonian rocks. The author of the present manuscript would very much like to know how Michaelsen (1998) could infer such folds from such great distance without accessing the outcrops on these steep slopes. The interpretation of tight folds within Lower-lowermost Upper Devonian rocks (of the Andrée Land Group/Mimerdalen Subgroup) by Michaelsen (1998) is, at most, tentative. In addition, her figure 39 clearly shows that the unconformity between Lower Devonian rocks and Permian strata is completely covered by grey screes that collapsed from exposures of the Wordiekammen Formation (see also Figures 2-14). Thus, any attempt to deduce the nature (tectonized or undeformed unconformity) of the boundary between Lower Devonian and Permian rocks from any of the photographs in Michaelsen (1998) and analysis of other outcrop transects (Figures 2-14) is essentially speculative. Good scientific practice strongly recommends to include the description of the uncertainty associated to one's interpretation of specific (e.g., field, seismic, petrological) data. Another interesting point of discussion: even if Dr. Piepjohn and his team mapped contractional structures along riverbeds at the bottom of the valley in Munidalen and Mimerdalen (i.e., not anywhere near the unconformity with overlying uppermost Devonian-Permian strata) and interpreted these structures as the downwards continuation of the Munindalen thrusts, these would still not be proofs that the faults correspond to Ellesmerian thrusts. The amount of early Cenozoic strain partitioning (including decoupling) accommodated by uppermost Devonian-Mississippian coals in Pyramiden and Sassefjorden-Tempelfjorden (present manuscript) and by Lower Devonian rocks in Billefjorden (Koehl et al., in prep. a; see Figure 28) could, alone, justify the large amounts of shortening and contractional structures within Devonian rocks of the Andrée Land Group/Mimerdalen Subgroup compared to realtively undeformed overlying uppermost Devonian-Permian strata of the Billefjorden and Gipsdalen groups. Koehl et al. (in prep. a) notably noticed that moderately dipping (Early) Devonian normal faults were mildly reactivated and involved into wide and

Printer-friendly version

Discussion paper
Interactive comment

\section{Discussion paper}

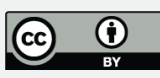


gentle fold structures affecting the entire Lower Devonian-Permian stratigraphy (see Figure 28). These fold structures on seismic data in Billefjorden are comparable in size (kilometer-scale) and geometry (open folds; see Figure 28) to the fold structures of the Dickson Land folds-thrust belt mapped by Dr. Piepjohn in Mimerdalen and Munindalen (Piepjohn et al., 1997a; Piepjohn, 2000). Comment 233: disagreed. The low-angle dip and juxtaposition of relatively young strata in the hanging wall against relatively old strata in the footwall are clearly comparable to the Woodfjorden detachment mapped (not by Chorowicz, 1992, but) by Roy $(2007,2009)$ and Roy et al. (unpublished). In addition, the Woodfjorden is indeed exposed on land in southern and southeastern Andrée Land (Roy, 2007, 2009; Roy et al., unpublished). Comment 234: partly agreed. The works mentioned by Dr. Piepjohn were made available to him. A "honest scientific argumentation" arguying for Ellesmerian deformation in central Spitsbergen based on field data and field observations and interpretations should probably support its claims with (an) actual field photograph(s). The only pro-Ellesmerian study showing such field photographs is Michaelsen (1998), and it is clear from the present discussion that some of these interpretations are highly questionable (see reply to Dr. Piepjohn's comment 232). Comment 235: these unconformities are also mentioned in Chorowicz (1992) in Andrée Land, and similar features aredescribed within sedimentary rocks of the Red Bay Group in northwestern Spitsbergen (Braathen et al., 2020). Moreover, the studies by Roy (2007) and Roy et al. (unpublished) were made available to Dr. Piepjohn. Comment 236: disagreed. The lone citation of Michaelsen's work would certainly be inappropriate in the present sentence, as suggested by Dr. Piepjohn. However, the citation of "Michaelsen et al. (1997, their figure 5a) and Michaelsen (1998, her figures 44 and 45)" (refering to specific figures) in the present manuscript is judged appropriate because it does not refer to their interpretation but to published field photographs. Reference to this work in this specific sentence is required since the outcrops and field relationships Michaelsen's field photographs show support the model argued for in the present manuscript. Comment 237: agreed. Dr. Piepjohn acknowledges that the "lower Munindalen Thrust is not unconformably overlain by 
Carboniferous rocks at the place" (i.e., Mimerdalen; Dr. Piepjohn's comment 237), and, thus, that the interpretation of an Ellesmerian thrust there involves a significant amount of uncertainty, including (1) that Dr. Piepjohn and Michaelsen's correlation of faults mostly (to completely) covered by screes across large fjord valleys is actually correct and (2) that the screes covering most (if not all) of the inaccessible (because located on steep cliffs) outcrops upon which Dr. Piepjohn and Michaelsen base their interpretation (not observation because not exposed) of a regional unconformity in every single place between Devonian rocks of the Andrée Land Group/Mimerdalen Subgroup and strata of the Wordiekammen Formation do not cover bedding-parallel décollements localized along the stratigraphic boundary as evidenced by the present manuscript (figure 3b) and by Koehl et al. (in prep. a; see Figure 28) in Billefjorden. The fact that the lower Munindalen thrust merges with the upper Munindalen thrust northwards may, instead of requiring the need for a full episode of contraction (according to Dr Piepjohn), simply mean that both the upper and the lower Munindalen thrusts are in fact Devonian, low-angle, normal, extensional detachments as suggested by reinterpretation of the upper Munindalen thrust of Michaelsen (1998)'s figure 53 into a Devonian extensional detachment/normal fault or alternatvely as a stratigraphic unconformity (see reply to Dr. Piepjohn's comment 232). Thus, even though the "merged Munindalen Thrust(s) are unconformably overlain by Carboniferous" (Dr. Piepjohn's comment 237) farther north, Ellesmerian deformation is not required to explain a probable unconformity with overlying uppermost Devonian-Permian strata of the Billefjorden Group and/or Wordiekammen Formation. Dr. Piepjohn's interpretation in the southern part of the Mimerdalen valley is tentative since both the upper and lower Munindalen thrusts are not exposed within the valley and are covered by Quaternary deposits (dashed character of lines representing upper and lower Munindalen thrusts in Dr. Piepjohn's figure 1; see his comment 61) and since no actual field photograph was ever published to support this claim and correlation. Noteworthy, the author of the present manuscript has indeed visited Mimerdalen in several occasions in 2015 and 2016 and could only remark that the southern flank of the valley shows essentially the same as the

Interactive comment
Printer-friendly version

Discussion paper

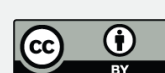


northern flank: cliff-outcrops transects mostly covered by screes, consisting mostly of loose material, and inaccessible by foot, and a possible unconformity completely covered by grey screes of the Wordiekammen Formation (see also Figures 2-14). As shown in the present manuscript, bedding-parallel duplexes and décollements are no more than a few meters wide/thick (see figure $3 \mathrm{~b}$ in the present manuscript) and, thus, could easily sit, in places, at the boundary between rocks of the Andrée Land Group/Mimerdalen Subgroup and uppermost Devonian-Permian strata, i.e., completely covered by screes in most places in Mimerdalen and Dickson Land. Comment 238: disagreed. Scientific evidences are not facts. The observations of the author of the present manuscript, such as steely east-dipping and partly overturned (west-dipping) bedding surfaces, are evidences used to support the author of the present manuscript's interpretation of field data, such as (in this case) the involvement of both Lower Devonian and uppermost Devonian-Mississippian strata in Pyramiden into early Cenozoic Eurekan top-WNW thrusting. Unfortunately, such a distinction is not respected by Dr. Piepjohn in his field studies about Ellesmerian deformation. In his contributions, raw observations (e.g., of the very poorly exposed character of the large outcrop transects he bases his interpretation on) are almost never reported, and neither is the uncertainty associated to his interpretations and models. Instead, only interpretations are reported in the form of idealized conceptual sketches and cross sections (e.g., Piepjohn, 1997b, his figure 6; Piepjohn et al., 1997a, their figures 9-12 and 14; Piepjohn, 2000, his figures 4, 6-8 and 10). The author of the present manuscript argues that these are not sufficient proofs to support the occurrence of Ellesmerian deformation in Spitsbergen since these interpretations are, as shown in the present manuscript and present discussion, based on partial and/or incomplete/indirect observations (outcrops inaccessible and almost completely covered by screes and/or made up mostly with loose material) and/or incorrect use of basic geological concepts (e.g., normal versus reverse fault; see reply to his comment 232). The author of the present manuscript does not wish to undermine the merits of Dr. Piepjohn's work and of the model of Ellesmerian deformation, but believes that other

Interactive comment

Printer-friendly version

Discussion paper

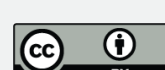


alternatives need to be further testes in the light of the various inconsistencies around the Ellesmerian hypothesis, e.g., non-synchronous timing in southern and northern Spitsbergen (Birkenmajer and Turnau, 1962), limited extent of deformation belts, no geochronological dating of Ellesmerian deformation in shallow-crustal Devonian sedimentary rocks, very low-quality palynological data in Buggisch et al. (1994) and Piepjohn et al. (2000), and so forth. Comment 239: agreed. Comment 240: agreed. Comment 241: disagreed. This is not an assumption, it is a claim that is based on a reinterpretation of field data by Michaelsen (1998) and Dissmann and Grewing (1997), on the similar structural strike and dip of these two faults, and on their structural alignment along a NNW-SSE-trending axis (see dotted black line in figure $1 \mathrm{~b}$ in the present manuscript). If the Munindalen thrust is not the southern continuation of the Robertsonbreen thrust, then where is this southern continuation located? or if the Robertsonbreen thrust does not continue to the south, then is it segmented? does it step? Is it offset? If so, by what fault(s)? Comment 242: agreed. Comment 243: agreed. Though the Kilen locality is indeed displayed in figure $1 \mathrm{~b}$ in the manuscript, the figure requires higher quality. Comment 244: disagreed. The claim in this sentence is supported by the presence of bedding-parallel duplexes and décollements along tectonized stratigraphic boundaries within uppermost Devonian-Mississippian coals (present manuscript; figure $3 \mathrm{~b}$ and $4 \mathrm{a}-\mathrm{b}$ ) and at the boundary between Devonian rocks of the Andrée land group/Mimerdalen Subgroup and the Wordiekammen Formation (McCann, 1993, his figure 5.6; Koehl et al., in prep. a, as shown in Figure 28), which partitioned and decoupled early Cenozoic deformation in Dickson Land. Again, the present study does not argue that "the base of the Wordiekammen Fm is a common, Eurekan detachment fault" (Dr. Piepjohn's comment 244), but rather that the local occurrence of such décollements along the mentioned stratigraphic boundaries acted as décollements and partitioned/decoupled Eurekan deformation, thus, locally allowing folding of Lower-lowermost Upper Devonian rocks of the Andrée Land/Mimerdalen Subgroup while overlying uppermost Devonian-Permian strata remained mostly undeformed, and, therefore, not requiring a phase of Ellesmerian deformation. What 
is "dangerous" (Dr. Piepjohn's comment 244) is Dr. Piepjohn's tendency to assume that only fieldwork and structural data may resolve geological problems. In addition, the present manuscript and present discussion clearly show that Dr. Piepjohn's assumption that the (probable) stratigraphic unconformity between Devonian rocks of the Andrée Land Group/Mimerdalen Subgroup and overlying rocks of the Billefjorden and Gipsdalen groups is highly questionable because essentially coered by screes almost everywhere in Dickson Land (also see Figures 2-25). Comment 245: agreed. Comment 246: agreed. Comment 247: disagreed. A comparison of Dickson Land with Brøggerhalvøya is appropriate because these two areas are located on either side of a major, hundred of kilometer-long reactivated Timanian fault that partitioned Eurekan deformation between northern and southern Spitsbergen (Koehl, 2019a, 2019b, 2020; Koehl et al., in prep. b). The tectonic situation of both of these areas is therefore relatively similar despite Eurekan thrusts showing opposite vergence. Comment 248: agreed. Comment 249: agreed. Comment 250: agreed. Sincere apologies to Dr. Piepjohn, who did not use such an argument in his contribution. Also agreed with Dr. Piepjohn in that the Minundalen thrust (although not a thrust) formed in Devonian times during extensional collapse, however, possibly as an extensional detachment or normal fault (or no fault and simply an intra-Lower Devonian stratigraphic unconformity). Comment 251: agreed. Comment 252: disagreed. Dr. Piepjohn does not address the Robertsonbreen thrust in his studies (Piepjohn et al., 1997a; Piepjohn, 2000), which is described in Dissmann and Grewing (1997). The correlation of the Robertsonbreen and lower Munindalen thrusts in the present manuscript is based on mapping by Dissmann and Grewing (1997) and Michaelsen (1998) showing that the Robertsonbreen has a similar geometry (low-angle), comparable kinematics (top-west to top-WSW) and aligns with the lower Munindalen thrust allow a NNW-SSE axis (see dotted black line in figure $1 \mathrm{~b}$ in the manuscript). Also see reply to Dr. Piepjohn's comment 241 for further discussion. Comment 253: agreed. Comment 254: agreed. Comment 255: disagreed. None of the evidence presented by Dr. Piepjohn show any tangible proof supporting his claim: no field photograph, no photographs of cross-

Printer-friendly version

Discussion paper
Interactive comment

\section{Discussion paper}

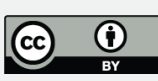


cutting relationships between these two faults, no actual outcrop photograph showing wel exposed undeformed unconformity truncating a potential Ellesmerian thrust, not to mention that one of the inferred Ellesmerian thrusts (the lower Munindalen thrust) is only speculated where it is believed to crosscut the Blåvatnet Fault as shown by the dashed character of the line marking the speculated continuation of the fault in figure 13 in Piepjohn et al. (1997a). Once again, Dr. Piepjohn provides no evidence whatsoever showing that the unconformity between the Blàvatnet Fault and the Wordiekammen Formation is not completely covered (and not completely inaccessible by foot) like in all other areas he has used to support Ellesmerian deformation in this area (Figures 2-25). The author of the present manuscript does not dispute the fact that "the Dickson Land fold-and-thrust zone as a whole is overlain by Carboniferous rocks, and the Carboniferous rocks on top are mostly undeformed" (Dr. Piepjohn's comment 255). What the present manuscript aims at showing is that Eurekan strain partitioning had dramatic effects in Spitsbergen and not only within the West Spitsbergen Fold-and-Thrust Belt. Notably in Dickson Land, local bedding-parallel décollements and duplexes along/near major stratigraphic boundaries (e.g., between rocks of the Andrée Land Group/Mimerdalen Subgroup and strata of the Billefjorden Group/Wordiekammen Formation; see McCann, 1993, his figure 5.6, figure 3b in the present manuscript, and Figure 28 from Koehl et al., in prep. a) may very well have prevented upward prolongation of inverted Early Devonian normal faults/extensional detachments and of new Eurekan folds and thrusts from rocks of the Andrée Land Group/Mimerdalen Subgroup into strata of the Billefjorden Group and Wordiekammen Formation. Mesoscale structures like bedding-parallel décollements, duplexes and thrusts facilitating strain partitioning and decoupling were not taken into account by studies arguying for Ellesmerian deformation in Spitsbergen. The hypothesis of Ellesmerian deformation therefore crucially needs reconsideration and reevaluation as suggested in the present manuscript. Dr. Piepjohn seems to consider that his geological maps may be used as evidences. However, since Dr. Piepjohn did not benefit from well preserved and easily accessible outcrops during his mapping (significant erosion 
of large portions of the faults and successions he has mapped), his maps are, like most geological maps, involving a certain (quite high) amount of uncertainty, which is discussed in the present manuscript and present discussion and illustrated by actual field photographs in the present discussion (Figures 2-25). The author of the present manuscript agrees with Dr. Piepjohn in that "the steeply inclined [...] faults do not cut through the horizontal Carboniferous and younger cover" (Dr. Piepjohn's comment 255), and some of the possible reasons why they do not are (1) a very short-lived episode of intense contractional-transpressional deformation (Ellesmerian deformation) that must have occurred between 383-380 Ma in northern Spitsbergen and in late Visean-Serpukhovian times in southern Spitsbergen based on most accurate paleontological and palynological studies (Birkenmajer and Turnau, 1962; Scheibner et al., 2012; Lindemann et al., 2013; Berry and Marshall, 2015; Marshall et al., 2015; Newmann et al., 2019; Lopes, pers. comm. 2019), or (2) Devonian extensional detachment faulting and folding and subsequent strain partitioning and decoupling during early Cenozoic Eurekan deformation resulting in intense deformation within shale-rich strata of the Andrée Land Group and Mimerdalen Subgroup (e.g., Koehl et al. in prep. a; Figures 28, 30 and 31), within uppermost Devonian-Mississippian coaland shale-rich strata of the Billefjorden Group (present manuscript's figure $3 b$ and 4b), and along stratigraphic boundaries/evaporite-rich strata of the Wordiekammen Formation (present manuscript's figure 4a, c, d and f and Figure 28 from Koehl et al. in prep. a), and/or (3) that these faults do not exist and are simple stratigraphic unconformities (suggested by the present manuscript and by Bergh et al., 2011 for some of Dr. Piepjohn's Ellesmerian thrusts) that were tilted during Devonian normal and extensional detachment faulting. Notably, Bergh et al. (2011) strongly disagreed with Dr. Piepjohn's mapping of Ellesmerian thrusts writing: "Piepjohn (2000) mapped this contact as a thrust, but we consider it to be an angular unconformity as there is no stratigraphic repetition or omission across the contact that necessitates a fault. In addition, there is a lack of fault rock development or small-scale structures in close proximity to the contact, and the overlying strata have a character consistent with 
an origin as a basal sequence above an unconformity". The author of the present manuscript disagrees with Dr. Piepjohn in that "the big sub-Carboniferous deformation is pre-Carboniferous" (Dr. Piepjohn's comment 255 referring to folds in Devonian rocks of the Andrée Land Group and Mimerdalen Subgroup) in age because of the strong evidence (not taken into account by Dr. Piepjohn and his team) of Eurekan strain partitioning in central Spitsbergen presented in the present manuscript, Koehl et al. (in prep. a; also see Figure 28), Harland et al. (1988), Ringset and Andresen (1988), and Braathen et al. (2011, e.g. their figure 7c showing localization of Eurekan thrusting within Pennsylvanian evaporites in Billefjorden), and by numerous other authors in the West Spitsbergen Fold-and-Thrust Belt (Maher et al., 1997; Braathen et al., 1999a, 1999b; Bergh et al., 2000; Leever et al., 2011a, 2011b). The present manuscript does not attempt at reinterpreting every single reverse fault mapped/inferred by Dr. Piepjohn and his team as Devonian extensional detachments, or Eurekan thrusts, or stratigraphic unconformities. The present manuscript simply reinterprets the very few of these faults (e.g., lower and upper Munindalen thrusts) used by Dr. Piepjohn and his team to infer a doubtful event of shallow-crustal Ellesmerian deformation. Since these few faults are indeed possible to reinterpret (as Devonian extensional detachments, or Eurekan thrusts, or stratigraphic unconformities), the hypothesis of Ellesmerian deformation needs very careful reconsideration. Again, the high concentration of contractional deformation within Devonian rocks of the Andrée Land Group and Mimerdalen Subgroup is much more likely to be the result of Eurekan strain partitioning (involving only one tectonic episode) rather than being the results of Ellesmerian and superimposed Eurekan deformation. Comment 256: the limited and localized extent of proposed Ellesmerian fold and thrust belts is an argument against Ellesmerian deformation because it shows that the model of Ellesmerian deformation works only for a few very specific localities, mostly in Devonian rocks of the Andrée Land Group, which are prone to localize deformation because of their enrichment in weak shales (e.g., Figure 31). On the contrary, Grenvillian, Caledonian, and Eurekan deformation, and Devonian-Carboniferous normal faulting were recorded throughout

Printer-friendly version

Discussion paper
Interactive comment

\section{Discussion paper}

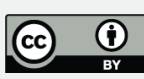


Spitsbergen (in rocks of corresponding age) and are not exclusively restricted to a few narrow areas. The localized character of proposed Ellesmerian deformation zones only tells about the nature of deformation, i.e., partitioned and not the same throughout the stratigraphic column. Discussing the Pretender Mountain locality is a key argument showing that Spitsbergen was not affected by Ellesmerian deformation. If Ellesmerian tectonism was to have affected Spitsbergen, it should be possible to record in every pre-Carboniferous rock unit, especially in northern Spitsbergen. This is not the case. It is therefore highly unlikely that the deformation observed in adjacent areas on either side of Pretender (Blomstrandhalvøya in the west, and Dickson Land in the east) should reflect Ellesmerian tectonism. Interpretations of Ellesmerian structures geometries, vergence, and timing throughout Spitsbergen all involve major inconsistencies. For example, Dr. Piepjohn used the dominant west vergence of folds and thrusts in northern Spitsbergen to segregate these structures from east-verging Eurekan folds and thrusts of the West Spitsbergen Fold-and-Thrust Belt (see his figure 2 attached to the present discussion; Dr. Piepjohn's comment 62). However, he abandonned his own logics to distinguish Ellesmerian from Eurekan folds and thrusts in southern Spitsbergen. The author of the present manuscript wonders whether there is a scientific argument/reason for this. Noteworthy, the only discriminating factor used by Dr. Piepjohn and other workers to distinguish Ellesmerian from Eurekan folds and thrusts in southern Spitsbergen (apart from interpretations of physically inaccessible and mostly covered outcrops) is the stratigraphic unit in which the structures were mapped: folds and thrusts mapped within Devonian rocks, e.g., of the Marietoppen and Adriabukta formations, were arbitrarily ascribed to Ellesmerian tectonism despite showing trends and strikes very similar to those of Eurekan structures in post-Devonian sedimentary units (see Bergh et al., 2011, their figures $8 \mathrm{~b}$ and 9a showing that folds and thrusts in both Devonian and younger sedimentary units are sub-horizontal and trend NNW-SSE). Again, the westwards transport direction of Eurekan folds and thrusts in northern Spitsbergen (misinterpreted as Ellesmerian structures) reflects strain partitioning during kilometer-scale sinistral-reverse oblique-slip reactivation of a 
major, hundreds of kilometer-long top-SSW to top-SW Timanian fault extending from Kongsfjorden to Sassenfjorden, Storfjorden and the northern Barents Sea (Koehl, 2019a, 2019b, 2020; Koehl et al., in prep. b) and possibly all the way to northwestern Russia (Klitzke et al., 2019). Geodynamic modelling further suggests that major NW-SE-striking Timanian faults throughout the Svalbard Archipelago provide (for the first time) a plausible explanation for the strike and formation of major transform faults (Spitsbergen and Molloy fracture zones) in the Fram Strait in the late Cenozoic (Beaussier, pers. comm. 2019). Seismic interpretation further suggests that Timanian faults also explain the presence of transform-parallel oceanic core complex and gas seepage along the Vestnesa Ridge west of Spitsbergen (Panieri et al., 2018; Koehl, 2019a, 2020) and of recent and ongoing earthquake sequences in Storfjorden (Pirli et al., 2013; Koehl, 2019a, 2020; Koehl et al., in prep. b). The "fracture cleavage formation indicating west-directed transport directions" in "the less-deformed areas between the [Ellesmerian] deformation belts" (Dr. Piepjohn's comment 256) mentioned by Dr. Piepjohn as an argument supporting Ellesmerian deformation may as well be early Cenozoic in age since there are no post-Devonian rocks preserved in areas like Blomstrandhalvøya and since the west-vergence of presumed Ellesmerian structures is actually related to strain partitioning by a large NW-SE-striking fault running from Kongsfjorden to Sassenfjorden, Storfjorden and the northern Barents Sea (Koehl, 2019a, 2019b, 2020; Koehl et al., in prep. b). Again, the deformation belt in Blomstrandhalvøya in dealt with in section 5.2, lines 1046-1076 and structures there are easily reinterpreted as early Cenozoic Eurekan thrusts since the only arguments used to infer an Ellesmerian age are (1) their west-verging character (which are, according to ongoing work by the author of the present manuscript, imputable to strain partitioning by a hundreds of kilometer-long Timanian thrust reactivated during Eurekan deformation; Koehl, 2019a, 2019b, 2020; Koehl et al., in prep. b), (2) highly uncertain field relationships (Buggisch et al., 1994, their figure 4), and (3) a timing based on a poorly preserved Conodont assemblages (Buggisch et al., 1994). Comment 257: agreed. Comment 258: disagreed. Eurekan did affect rocks throughout Spitsbergen, 
including at Pretender (see Eurekan thrusts localized within lower Permian sedimentary rocks overlying the Devonian strata mentioned in this comment in Dallmann, 2015, pp. 154). As mentioned a few comments ago, Eurekan did, indeed, affect Spitsbergen pervasively, which is not the case of Ellesmerian deformation (supposedly preserved in only a few belts). Even Caledonian deformation was preserved in almost all exposed Proterozoic basement rocks throughout Spitsbergen, so why not Ellesmerian deformation? Simply because it most likely did not occur. Regarding the vergence of presumed Ellesmerian structures, see reply to previous comments (e.g., comment 256). Due to strain partitioning between northern and southern Spitsbergen, the opposite vergence of folds and thrusts in post-Caledonian sedimentary rocks in northern (west-verging) and southern Spitsbergen (east-verging) cannot be used as an argument to distinguish Ellesmerian from Eurekan structures. The author of the present manuscript is curious to know about the scientific evidences used by Dr. Piepjohn to infer (speculate?) about the "possible existence of a deep-seated Ellesmerian detachment with upramping reverse faults, probably due to pre-existing faults that can explain the occurrences of the Ellesmerian deformation zones". Has Dr. Piepjohn analyzed any geophysical dataset or exploration well data that could allow him to discuss these deep-seated faults? Is so, are these data and his interpretation of these data published? Comment 259: disagreed. The model of core complex by Prof. Braathen and his co-workers is not an assumption but an interpretation/model based on structural and geochronological data published in Braathen et al. (2018a) that Dr. Piepjohn disagrees with (e.g., Dallmann and Piepjohn, 2018). The present manuscript does neither intend to dispute that "The Pretender Fault is a post-Carboniferous and probably also a post-Eurekan fault" nor to compare "the Pretender Fault with the assumption of the core complex" (Dr. Piepjohn's comment 260). The author of the present manuscript agrees with Dr. Piepjohn in that the Pretender Fault is a younger feature. The present manuscript compares the geological situation in the Pretender area (gently tilted Lower Devonian rocks unconformably overlain by flat-lying Permian strata) and its potential relationship with the southern continuation of the Bockfjorden

Interactive comment
Printer-friendly version

Discussion paper

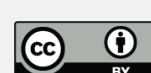


Anticline (i.e., located along/over the crest of the core complex). The author of the present manuscript has, indeed, data that support the core complex hypothesis of Prof. Braathen and his co-workers in northwestern Spitsbergen. However, these data are not field data, but aeromagnetic data from the Geological Survey of Norway (Koehl, 2019a, 2019b, 2020). Comment 260: agreed. Yes, the author of the present manuscript has "heard about the Nordfjorden High between the St. Jonsfjorden and Billefjorden Troughs" (Dr. Piepjohn's comment 260; e.g., Steel and Worsley, 1984; Ahlborn and Stemmerik, 2015). The author of the present manuscript also agrees that "there are correlatives of the Billefjorden Group on Broeggerhalvoeya and further south", but these are located away from the core complex of Braathen et al. (2018a), which is offset left-laterally by 8-12 kilometers by a major, NW-SE-striking, inherited Timanian fault and, most likely, continues southwards in Isfjorden (Koehl, 2019a, 2019b, 2020). This is not an assumption, but a claim based on interpretation of aeromagnetic and seismic data throughout Spitsbergen (Koehl, 2019a, 2019b, 2020; Koehl et al., in prep. b) and careful review of relevant literature suggesting the presence of a basement ridge comparable in size to the Bockfjorden Anticline core complex in Isfjorden (e.g., Bergh et al., 1997; Blinova et al., 2012). The author maintains that deformation events such as the Eurekan event and Carboniferous normal faulting affected Spitsbergen pervasively, even in areas where they are not recorded by syn-tectonic sedimentation (e.g., shearing of Cretaceous dolerite in Hinloppen during Eurekan tectonism, e.g., Frebold, 1935, and normal faulting within basement highs without syn-tectonic sedimentary strata onshore Bjørnøya, e.g., Worsley et al., 2001, their figure 4), which is not the case of Ellesmerian deformation. The author of the present manuscript agrees with Dr. Piepjohn in that the absence of syn-tectonic sedimentary strata is not a counter argument to the occurrence of a specific tectonic event. However, the absence of deformation structures related to this tectonic event in most places of the investigated area may be used as a counter argument if more arguments against this particular tectonic episode are to be found. In the present case, the localization of Ellesmerian deformation in narrow fold and thrust belts as 
suggested by Dr. Piepjohn strongly contrasts with the widely documented occurrence of Eurekan strain partitioning throughout the West Spitsbergen Fold-and-Thrust Belt (Maher et al., 1997; Braathen et al., 1999a, 1999b; Bergh et al., 2000; Leever et al., 2011a, 2011b) and central Spitsbergen (Ringset and Andresen, 1988; Harland et al., 1988; Braathen et al., 2011; present manuscript; Koehl et al., in prep. a) and, thus, suggest that shallow-crustal to near-surface Ellesmerian deformation did not occur in Spitsbergen. Comment 261: agreed. Comment 262: agreed. The core complex hypothesis is still a work in progress of Prof. Braathen in northwestern Spitsbergen (e.g., Braathen et al., 2020) and by the author of the present manuscript in western, central and southern Spitsbergen (e.g., Koehl, 2019a, 2019b, 2020). The fact that Dr. Piepjohn does not agree with this model/interpretation does not remove its merit: to explain the presence of extensional detachments on the flanks of major NNW-SSE-trending basement ridges (most likely initiated by Caledonian folding) and document the presence low-angle Devonian extensional detachments throughout Spitsbergen (e.g., Woodfjorden Detachment in Andrée Land, moderate-low-angle normal faults in Kota and Mimerdalen; Roy, 2007, 2009; Roy et al., unpublished). The claims of Dr, Piepjohn that in the west it is an east-directed (not north-directed) reverse fault (Friedrichbreen Fault) which can be interpreted as possible Eurekan structure and "in the east [of the Bockfjorden Anticline, the boundary] is a post-Devonian normal fault and" (Dr. Piepjohn's comment 262) are not incompatible with the interpretation of a Devonian bowed/curving-upwards extensional detachment since the detachment may very well have provided preferential zones of weakness to localize subsequent Carboniferous normal faults and Eurekan reverse faults. The author of the present manuscript also agrees that the amount of top-north extension mentioned by previous workers (McCann, 2000 and Braathen et al., 2018a) might have been overestimated, especially since NNE-dipping normal faults in northwestern Spitsbergen were likely inverted during early Cenozoic Eurekan deformation, thus explaining the significant SSW-tilt of Devonian strata (Friend et al., 1997, their figure 12b and c) on which the estimations of top-north extension of McCann (2000) and Braathen et al. (2018a) are 
based on (also see discussion in Koehl et al., in prep. a). The author of the present manuscript also agrees that Proterozoic basement rocks in northwestern Spitsbergen likely preserved marks of the Caledonian Orogeny. However, the author of the present manuscript does not agree with Dr. Piepjohn when he writes that "there are no kinematic indications for northwards movements within the Devonian" (Dr. Piepjohn's comment 262) since both Friend et al. (1997) and McCann (2000) reported Devonian strata northerly tilted (at c. $45^{\circ}$ ) against NNE-dipping normal faults, some of which merge with the Keisarhjelmen Detachment (Braathen et al., 2018a). The fact that some of these NNE-dipping faults crosscut (and offset?) the Bockfjorden Anticline is by no means incompatible with the interpretation of a major bowed Devonian detachment (Keisarhjelmen Detachment) by Braathen et al. (2018a) since these NNE-dipping faults may have reactivated during Carboniferous and/or late Cenozoic extension and/or early Cenozoic Eurekan deformation. The paper by Braathen et al. (2018a) is not disregarding E-W shortening in the Bockfjorden area, it is simply not focused on this particular topic. As discussed in the present manuscript and present discussion, E-W shortening in Lower-lowermost Upper Devonian sedimentary rocks of the Andrée Land Group and Mimerdalen Subgroup in northern Spitsbergen is Eurekan in age and, thus, has nothing to do with Devonian core complex exhumation discussed in Braathen et al. (2018a) Dr. Piepjohn's claim that the core complex exhumation in northwestern Spitsbergen is correct "only, if the geological mapping and structural observations are correct" can be applied to Ellesmerian Orogeny (and pretty much to any geological hypothesis ever made). The present manuscript clearly shows that many structural observations used to support the occurrence of Ellesmerian deformation in Spitsbergen are most likely incorrect, e.g., the interpretation of the Munindalen thrust (see also reply to Dr. Piepjohn's comment 232), the excessive interpretations of Ellesmerian thrusts by Dr. Piepjohn and his team (e.g., Bergh et al., 2011; see also reply to Dr. Piepjohn's comment 255), the distinction between Ellesmerian and Eurekan structures in Hornsund (see also replies to Dr. Piepjohn's comments 36 and 52), and the use of the west-vergence of Ellesmerian structures 
in northern Spitsbergen to distinguish them from Eurekan thrusts (see also reply to Dr. Piepjohn's comment 256). When Dr. Piepjohn writes that the "contacts between the base of the ORS and the underlying basement in the Liefdefjorden area are not tectonic but sedimentary" and that "the Devonian Red Bay Group unconformably overlies carstified and heavily weathered marbles without any tectonic structures", has he used observations of outcrops of similar quality as in Dickson Land, where the contact between Devonian rocks of the Andrée Land Group/Mimerdalen Subgroup and uppermost Devonian-Permian rocks of the Billefjorden and Gipsdalen groups was interpreted (not observed as claimed by Dr. Piepjohn) from great distance and on outcrop transects that are mostly inaccessible, consisting of loose material and covered by screes (Figures 2-25)? If not, has Dr. Piepjohn published any field photograph of these contacts? Comment 263: agreed. Reference to the work of Piepjohn and Dallmann (2014) only applies to "the presence of coarse-grained sedimentary deposits" (line 1041 in the present manuscript). Comment 264: agreed. Comment 265: indeed, Kempe et al. (1997; in German) did describe NW-verging thursts in Blomstrandhalvøya (pp. 126 in Kempe et al., 1997): "imbricate fans mit nach NW gerichteten Transporten in den Marmoren aus" (lower left corner paragraph), which translates into "imbricate fans with top-NW transport direction in the marble". Comment 266: the author of the present manuscript refers Dr. Piepjohn to the work of Kempe et al. (1997) of which Dr. Piepjohn is a co-author. About NW-directed thrusts, Kempe et al. (1997) wrote (in German): "Diese Deformation, die in ihren Ausmaßen im Gegensatz zu der prä-oberkarbonischen svalbardischen Deformation äußerst gering ist, mu $\beta$ daher post-karbonisch sein. Die Orientierung der Achsen, die Transportrichtungen der imbricate fans und die Vergenzen der Falten nach NW sind senkrecht zur Transportrichtung der tertiären Deformation des West Spitsbergen Fold-and-Thrust Belts ortientiert und sprechen gegen eine Bildung dieser Strukturen während des Tertiärs. Demnach kommt für die zeitliche Einordnung dieser kleinräumigen tektonischen Phase der lange Zeitraum zwischen Oberkaron und Alttertiär in Frage. Eine genauere Zuordnung wird wahrscheinlich wegen des lokalen Auftretens 
dieser Deformation nicht mehr möglich sein", which translates into "This deformation, which is extremely small in comparison to the pre-upper Carboniferous Svalbardian deformation, must therefore be post-Carboniferous. The orientation of the axes, the transport directions of the imbricate fans and the narrowing of the folds to the north are oriented perpendicular to the transport direction of the Tertiary deformation of the West Spitsbergen Fold-and-Thrust Belt and argue against the formation of these structures during the Tertiary Period. Accordingly, the long period between upper Carboniferous and early Tertiary is suitable for the temporal classification of this small-scale tectonic phase. A more precise assignment will probably not be possible due to the local occurrence of this deformation". The author of the present manuscript would like to point out that Kempe et al. (1997), instead of simply ascribing NW-directed thrust to Eurekan deformation, argued for a new phase of deformation in Svalbard (between the Pennsylvanian and the early Cenozoic) only because the transport directions and trends of the structures they observed do not match those of early Cenozoic thrusts in Brøggerhalvøya. The author of the present manuscript believes that this is (at present day) a relatively weak argument since the early Cenozoic reactivation of a major NNE-dipping Timanian fault as a top-SSW, sinistral-reverse fault in Kongsfjorden most likely partitioned deformation between northern (including Blomstrandhalvøya) and southern Spitsbergen (including Brøggerhalvøya; Koehl, 2019a, 2020). Hence, since there is no known episode of contractional-transpressional deformation between the Pennsylvanian and the early Cenozoic in Spitsbergen, the author of the present manuscript argues that these top-NW imbricate thrusts described by Kempe et al. (1997) on Blomstrandhalvøya are most likely early Cenozoic Eurekan thrusts. Comment 267: the author of the present manuscript refers Dr. Piepjohn to his ResearchGate profile (Jean-Baptiste Koehl) where all the scientific contributions by the author of the present manuscript are available. The present sentence is based on evidence from aeromagnetic and gravimetric data over Spitsbergen from the Geological Survey of Norway (Koehl, 2020, pp. 120-129), bathymetric data in Kongsfjorden from the Norwegian Mapping Authorities (Koehl, 2020, pp 104-112), and 
seismic data from the Norwegian Petroleum Directorate showing the continuation of the Bockfjorden Anticline in Isfjorden (e.g., Koehl, 2020, pp. 55-68; also identified by Bergh et al., 1997 and Blinova et al., 2013) displaying a c. 10-12 kilometers left-lateral offset and top-SSW c. 4-5 kilometers reverse offset across a major Timanian fault extending from Kongsfjorden to Sassenfjorden (e.g., Koehl, 2020, pp. 69-119) and the northwestern Barents Sea (Klitzke et al., 2019). Regarding on-land evidence, Dr. Piepjohn is referred to the work by van Boeckel $(2018)$ in small islands in Kongsfjorden showing the presence of two dominant fault sets, one of which strikes NW-SE (his figures 13 and 39). This massive geological structure is not yet on any geological maps because it was discovered only recently (two years ago) by the author of the present manuscript (Koehl, 2019a, 2019b, 2020; Koehl et al., in prep. b). The upper (brittle) part of this crustal-scale NNE-dipping fault is visible on seismic sections in Sassengfjorden-Tempelfjorden (not in Isfjorden), actually in the present manuscript (figure $4 a-b$ ). This NNE-dipping fault is also mapped in figure $1 \mathrm{~b}$ in the manuscript, but since it is not the focus of the present manuscript, only the section of the fault covered by seismic data shown in the present manuscript is drawn. Noteworthy, the trace of this fault correlates with a major WNW-ESE- to NW-SE-trending, c. 10 kilometers wide bump in the seafloor in southern Billefjorden and Sassenfjorden-Tempelfjorden (also visible on bathymetry data in Blinova et al., 2012, their figure 6) attesting of its recent-ongoing activity as suggested by seismological data of recent (2008-2017) earthquakes in Storfjorden (Pirli et al., 2013; Koehl, 2020, pp. 116-119). The fact that Dr. Piepjohn and his team did not find any evidence for the presence of such fault in Blomstrandhalvøya and Brøggerhalvøya using only field investigation does, by no means, suggest that this fault does not exist. The trace of the fault actually runs within Kongsfjorden at the location suggested for the Kongsvegen Fault and Lappdalen Thrust (Harland and Horsfield, 1974, their figure 2; Harland and Wright, 1979, their figure 1). The author of the present manuscript does not believe that Dr. Piepjohn's field observation are not serious, simply that they were made using only fieldwork and at a time when combining multiple datasets and sub-disciplines was not the most 
common approach. Again, this major fault appears on gravimetric, aeromagnetic, seismic and bathymetric data in Spitsbergen. Comment 268: it seems like Dr. Piepjohn and the author of the present manuscript agree on the fact that, apart from a few thrusts, the basement rocks in "The areas between the thrusts are mostly undeformed" (Dr. Piepjohn's comment 268). These areas between the thrusts make up the most of the peninsula (see geological maps in, e.g., Thiedig and Manby, 1992, their figure 2; Buggisch et al., 1994, their figure 2; Kempe et al., 1997, their figure 2). The author of the present manuscript also agrees that the "cave rocks [along the west coast of Blomstrandhalvøya] are absolutely undeformed" (i.e., the sedimentary infill of the lone cave dated by poorly preserved Conodont assemblages in Buggisch et al., 1994) and as undeformed as basement marbles there (Buggisch et al., 1994, their figure 4). The author of the present manuscript argues that it is most natural that the cave infill is undeformed since the rocks along the west coast of the peninsula are poorly to not deformed at all either (see geological maps in Thiedig and Manby, 1992; Buggisch et al., 1994; Kempe et al., 1997). Thus, it is not possible to use the undeformed character of the sedimentary infill of this cave to deduce the timing of top-west thrusting on Blomstrandhalvøya. Notably, figure 4 in Buggisch et al. (1994) shows the undeformed character of basement marbles around the undeformed cave, and their figure 8 clearly shows that the cave is located away (though not so far away) from areas affected by Eurekan (although presumed Ellesmerian by Dr. Piepjohn) top-west folding and thrusting. If the marbles near the cave are a little deformed, this deformation may well be Caledonian in age as suggested by a recent paleomagnetic study in Kongsfjorden (Michalski, 2018; see reply to comment 21 of the anonymous referee for further discussion). Comment 269: disagreed. Though Dr. Piepjohn does not agree with any other workers (Scheibner et al., 2012; Lindemann et al., 2013; Berry and Marshall, 2015; Marshall et al., 2015; Newman et al., 2019; Lopes, pers. comm. 2019) about the age of sedimentary rocks of the Pantekløfta Formation and Billefjorden Group (Piepjohn et al., 2000), Dr. Piepjohn (2000) still argued that Ellesmerian deformation occurred prior to the deposition of the Billefjorden Group. Comment 270: disagreed. 
Dr. Piepjohn is not an expert in paleontology or palynology and the identification of a lone specimen of misidentified Fammenian Retispora lepidophyta spore within strata of the Plantekløfta Formation (published in Schweitzer, 1999, plate 6 in their figure 10 and plate 7 in their figure 1) was invalidated for several reasons by experts in the matter (see Berry and Marshall, 2015, their supplement DR3). In addition, the argumentation of Dr. Piepjohn does not align with any recent dating by paleontological and palynological experts (e.g., Scheibner et al., 2012; Lindeman et al., 2013; Berry and Marshall, 2015; Marshall et al., 2015; Newman et al., 2019; Lopes, pers. comm. 2019). Again, the base of sedimentary rocks of the Billefjorden Group in central Spitsbergen was dated to the mid-late Fammenian by several teams of experts in paleontology and palynology (Lindemann et al., 2013; Marshall et al., 2015; Lopes, pers. comm. 2019) and, thus, Ellesmerian deformation (if it ever occurred) must have taken place and ended by the mid-late Fammenian. The claim of Dr. Piepjohn that spores in the Billefjorden Group were reworked is based on nothing more than speculation since his sample of Retispora lepidophyta is a clear misidentification (Berry and Marshall, 2015, their supplement DR3 and reply to Dr. Piepjohn's comment 19 for further discussion). The present manuscript does not debate the possible timing of Ellesmerian deformation elsewhere than in Spitsbergen. Regarding "new ages for amphibolite metamorphism on Prins Karls Forland at ca. 360 Ma" (Dr. Piepjohn's comment 270), the present manuscript discusses a reinterpretation of this age based on inconsistent shear sense indicators (normal instead of reverse) along the Bouréefjellet fault zone of Schneider et al. (2018). Research on metamorphic core complexes have clearly demonstrated that amphibolite facies conditions are commonly reached during post-late-orogenic collapse (Krabbendam and Dewey, 1998) along core complex-bounding detachments and shear zones (e.g., Snoke, 1980; Lister and Davis, 1989; Beaudoin et al., 2015; Yin et al., 2017). Furthermore, despite the possible prograde character of the amphibolite-facies metamorphism in Prins Karls Forland postulated by Kosminska et al. (2020), it is much more probable that potential contraction associated with this deep (> 15 kilometers deep?) metamorphic episode 
is related to contemporaneous Late Devonian-Mississippian eclogite-facies metamorphism in northeastern Greenland (the conjugate margin of Svalbard across the North Atlantic Ocean), which was due to deep late Caledonian movements (Gilotti et al., 2004; McClelland et al., 2006) that were coeval with the deposition of shallow-crustal Devonian-Mississippian basins along low-angle detachments during Caledonian extensional collapse (Stemmerik et al., 1991, 1998, 2000; Larsen and Bengaard, 1991; Strachan, 1994; Larsen et al., 2008; also see reply to anonymous referee's comment 22 for further discussion). Coeval deep contraction and shallow-crustal extension is, indeed, common during extensional collapse (Platt, 1986; Rey et al., 2001; Teyssier et al., 2005). Chorowicz (1992), Roy (2007, 2009) and Roy et al. (unpublished) even suggested that sediments of the Billefjorden Group actually represent continued sedimentation associated to late-post-Caledonian collapse in Spitsbergen. Comment 271: the author of the present manuscript does not know whether Bergh et al. (2011) have "seen the large-scale fold-structures in the Devonian south of Hornsund which are unconformably overlain by Triasssic". Again, the unconformity described by Dr. Piepjohn at this locality (Røkensåta; Dallmann, 1992) is completely covered by loose material and, thus, is very likely to be reworked and tectonized, especially since the locality is located within the West Spitsbergen Fold-and-Thrust Belt. In addition, the folds in Devonian rocks in Røkensåta show comparable trends and plunge (Dallmann, 1992, his figure 11a) to Eurekan folds in Hornsund (Dallmann, 1992, his figure 11b; Bergh et al., 2011, their figure 9a) and to folds in the Adriabukta Formation (Bergh et al., 2011, their figure 8b), thus, suggesting that all these folds formed during the same tectonic event, Eurekan deformation. The fact that "folding in the Marietoppen and Adriabukta Fm at Adriabukta is signifcantly different to the Tertiary deformation observed in the post-Devonian sedimentary succession in the Soerkapp Land area" (Dr. Piepjohn's comment 271) is irrelevant to ascribe folding of the former two to Ellesmerian deformation, especially since Eurekan fold structures within overlying post-Mississippian sedimentary units at the same locality (Adriabukta) display similar trend and plunge as fold structures within Devonian-Mississippian sedimentary rocks 
of the Marietoppen and Adriabukta formations (again, see Bergh et al., 2011, their figures $8 \mathrm{~b}$ and $9 \mathrm{a}$ for comparison). The fact that folding within the Adriabukta Formation is more intense may simply be related to the relatively weak character the abundant shale units within this Formation compared with relatively more brittle sandstone and carbonates in overlying post-Mississippian and pre-Mississippian strata (i.e., Eurekan strain partitioning and decoupling). Comment 272: disagreed. A statement, whoever made it, does not constitute a proof if it not based on solid scientific evidence. Bergh et al. (2011) simply cite "W. Dallmann pers. comm. 2009" to support their claim that the Adriabukta Formation is more likely to be Late Devonian in age. As it turns out, it seems that the Visean palynological ages of Birkenmajer and Turnau (1962) are robust (see reply to Dr. Piepjohn's comment 52 for further discussion). Comment 273: agreed. This is exactly the point the present manuscript is trying to make. The (most probably) Early Cretaceous sills intruded the Adriabukta Formation along flat-lying (i.e., undeformed) bedding surfaces, which suggests that strata of the Adriabukta Formation were still flat-lying and undeformed in the Early Cretaceous and, thus, that they were not affected by EllesmerianSvalbardian deformation (see reply to Dr. Piepjohn's comment 39 for further discussion). Comment 274: disagreed. A (Late Devonian?-) Mississippian age for the two bedding-parallel dolerite intrusions in Adriabukta is not an assumption since it is based on the presence of Devonian-Mississippian in central Spitsbergen (Evdokimov et al., 2006). Comment 275: agreed. However, reference to figure $1 \mathrm{a}$ in the manuscript aims at reminding the reader that the location of Røkensåta is shown there. It is not meant to show the fold structures in Røkensåta, which is related to mention of "Dallmann, 1992" line 1137. Comment 276: disagreed. The present manuscript does not "state", it reinterpret field photographs and structural data interpreted in published works to show the existence of alternative models to the interpretation of Ellesmerian deformation. In addition, the manuscript clearly shows that, despite "many observations, mapping and structural fieldwork" (Dr. Piepjohn's comment 276), the arguments of previous workers are not good enough for their geological interpretation of Ellesmerian deformation in the light of the evolution of

Printer-friendly version

Discussion paper
Interactive comment

\section{Discussion paper}

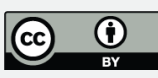


knowledge (e.g., present manuscript showing the presence of meter-scale structures possibly decoupling Eurekan deformation) and the evolution of field methods and data acquisition: regional fieldwork and interpretation of partly covered and inaccessible outcrop transects is not appropriate anymore to support or invalidate the occurrence of tectonic events such as the Ellesmerian event. Instead, the manuscript shows the crucial need for more detailed field studies of smaller but well-exposed and physically accessible outcrops. The author of the present manuscript also disagrees with Dr. Piepjohn when he writes that the author of the present manuscript "has never ever seen all the outcrops between Woodfjorden and Soerkapp" (Dr. Piepjohn's comment 276). The author of the present manuscript has seen every field photograph published in existing literature (quite a good deal of them in Roy, 2007, but also in Dallmann, 1992, 2015 and Dallmann and Piepjohn, submitted) and from recent field excursions in Dickson Land (Figures 2-25). The author of the present manuscript also disagrees with Dr. Piepjohn in that "all the previous geologists are not correct, that their mapping was wrong, that they have undertaken wrong interpretations and wrong observations, and that they have made thousands of wrong structural measurements". The present manuscript simply shows the large amounts of uncertainty involved in their mapping and interpretations and, hence, in the model of Ellesmerian deformation, which are based on partial and distant observations of physically inaccessible outcrops that are mostly covered (by screes) and consist mostly of loose material (see Figures 2-25). The author of the present manuscript personnaly knows Dr. Dallmann and believes that he (as much as Dr. Piepjohn) is a highly qualified field geologist who has had to map huge areas with limited budget and time and, thus, has had to have a distant look at most of the outcrop transects he studied (adopting a regional interpretation approach). Hence, the models discussed by Dr. Dallmann and Dr. Piepjohn involve large amounts of uncertainty in the interpretation of their (partial and distant) field observations. The author of the present manuscript does not pretend that he would have done a better job than Dr. Dallmann or Dr. Piepjohn in mapping rock units and faults throughout Svalbard. The author of the present manuscript recognizes and

Interactive comment
Printer-friendly version

Discussion paper

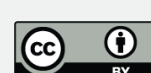


acknowledges the merit of Dr. Dallmann and Dr. Piepjohn's work in Svalbard, which resulted notably in the publication of the first Geoscience Atlas of Svalbard (Dallmann, 2015) and a long manuscript on Devonian deposits (Dallmann and Piepjohn, submitted) as well as many geological maps and scientific publications. The author of the present manuscript simply discusses the weaknesses of Dr. Dallmann and Dr. Piepjohn's mapping and interpretations (and models) in relationship with time and budget constraints that were (most probably) not for them to decide but for funding authorities and institutes. The author of the present manuscript has a most sincere respect for the professional achievements of Dr. Dallmann and Dr. Piepjohn, and all the previous geologists who have mapped Ellesmerian structures in Svalbard. The author of the present manuscript also does not think that Dr. Dallmann has "has always failed to interpret the [stratigraphic] contacts as unconformities instead of detachments" (Dr. Piepjohn's comment 276) since the present manuscript does not argue for (a) regional detachment(s) (as shown in Dr. Piepjohn's figure 3; see his comment 63), but rather for a combination of local Eurekan décollements and Devonian extensional detachments. Thus, the author of the present manuscript does not claim that "all the contacts are interpreted wrongly" (only in a few places, e.g., in Triungen along the Triungen-Grønhorgdalen Fault Zone, in Røkensåta, in Pyramiden). Furthermore, the author of the present manuscript argues that some outcrops are not possible to physically visit to collect measurements without outstanding rock-climbing skills and equipment and/or constant helicopter support (Figures 2-25). Hence, even though Dr. Piepjohn has seen from high distance the poorly exposed outcrop transects he has interpreted in Dickson Land, it does not mean that he has been able to guess correctly what lies beneath most of the loose material/screes covering most of these outcrops at every locality. The author of the present manuscript is not attempting to judge "what all the other geologists have done over the last 30 years", but simply to confront their models/interpretations with his own hypotheses and to integrate their observations with new data of various types (paleontological-palynological, seismic, satellite images, geochronological, petrological, exploration well). The measurements 
acquired by previous geoscientists in Svalbard are not "wrong", but were simply used to support a hypothesis that (to the eyes of the author of the present manuscript) is erroneous as suggested in the present manuscript. Acquiring new measurements would not lead to significant advancement since field measurements, e.g., by Dr. Dallmann, Dr. Piepjohn and Prof. Bergh (see reply to Dr. Piepjohn's comment ) already align well with and support the claim of the present manuscript that Eurekan folds and presumed Ellesmerian folds are not different from each other (similar trends, plunges and geometries; see Bergh et al., 2011, their figures $8 \mathrm{~b}$ and 9a). The suggestion of Dr. Piepjohn that previous workers (especially supporters of the Ellesmerian Orogeny in Svalbard) "have undertaken wrong interpretations and wrong observations" is most likely partly true because these previous workers based their interpretations and model on partial and distant observations of poorly preserved outcrop transects (e.g., see Dallmann, 1992, their figure 4a and Figures 2-25), thus involving high amounts of uncertainty. With regards to the "many "maybe's", "perhapses", "possibles", "more likelys"' (Dr. Piepjohn's comment 276), the author of the present manuscript argues that it is good practice in geosciences to use such terms since geological analyzes commonly involve uncertainties (i.e., impossibility to directly check the veracity of one's model). Dr. Piepjohn does not seem to be aware that his own field studies and interpretations of distant, poorly preserved, partly-mostly covered (by screes), discontinuous and mostly inaccessible outcrop transects in Dickson Land do involve large amounts of uncertainties (Figures 2-25). Comment 277: agreed. Once again, the author of the present manuscript would like to apologize for the prolonged unavailability of the mentioned contributions. The study by Roy et al. (unpublished) was supposed to be published (was submitted?) in the Norwegian Journal of Geology. Again, Prof. Chorowicz's argument for not going further with his mapping of Devonian extensional detachments and folds is related to his running out of funding (Chorowicz, pers. comm. 2019). The mentioned contributions are now available to Dr. Piepjohn. Comment 278: agreed. Which is why the present manuscript quickly eliminates this possibility since no other records 
exist corroborating Uralian tectonism in Svalbard. But this is exactly what happened to the Ellesmerian deformation. Observations of presumed Ellesmerian deformation were made on poorly exposed and essentially covered (by screes) outcrop transects from great distance (Figures 2-25) and structural measurements were made along riverbeds at the bottom of valleys and fjords (i.e., not directly on the interpreted outcrop transects). Hence, it is very likely that erroneous correlations were made between actually observed thrusts and folds along riverbeds and wrongly interpreted faults on associated outcrop transects (e.g., upper Munindalen thrust in figure 53 in Michaelsen, 1998). In addition, the depositional ages of certain stratigraphic units (e.g., Adriabukta Formation and Plantekløfta Formation) obtained by supporters of the Ellesmerian Orogeny in Spitsbergen are based on very poor data (Piepjohn et al., 2000) and unsupported claims ("W. Dallmann pers. comm. 2009" in Bergh et al., 2011). Thus, it is more probable that Ellesmerian deformation did not occur in Spitsbergen. Comment 279: yes, it is based on real field observations made by Bergh et al. (2011) and on a restoration (prior to early Cenozoic Eurekan deformation) provided in the present manuscript. Comment 280: disagreed. No, the present manuscript does "take the asssumed eastward dip of the Marietoppen and Adriabukta fms as an indication and evidence for a core complex" (Dr. Piepjohn's comment 280), but rather the eastwards dip and pre-Pennsylvanian normal kinematics of the Mariekammen Shear Zone after restoration prior to Eurekan deformation (figure 5 in the manuscript). Since it is obvious that the Adriabukta area was affected by top-east Eurekan folding and thrusting (see folds in post-Mississippian sedimentary strata in Birkenmajer, 1964 and Bergh et al., 2011), the Mariekammen Shear Zone therefore needs to be restored in its original position prior to this episode of deformation to investigate its potential geometry and kinematics during Ellesmerian deformation. As it turns out, the restoration shows that the shear zone actually displays a normal sense of shear, thus potentially supporting core complex exhumation in the west. This restoration process is commonly used in salt tectonics and interpretation of seismic data in structurally complex areas (e.g., Rojo and Escalona, 2018). Unfortunately, the study of von Gosen and Piepjohn 
(2001) in Adriabukta is not accessible to the author of the present manuscript and therefore cannot (yet?) be discussed in the present manuscript. Comment 281: disagreed. It is a simple attempt at explaining the presence of basement slivers along the Mariekammen Shear Zone within sedimentary rocks of the Adriabukta Formation in the light of the new normal sense of shear of the shear zone in (Late Devonian?-) Mississippian times. This alternative involves a certain level of uncertainty as do alternatives proposed by Bergh et al. (2011) and other workers. However, the proposed alternative takes into account the impact of Eurekan deformation and attempted to segregate Eurekan from Ellesmerian deformation, thus involving less uncertainty than alternatives by Bergh et al. (2011). Comment 282: alright. Comment 283: agreed. Comment 284: disagreed. In the light of the correlation of the Påskefjellet area with a NNW-SSE-trending positive magnetic anomaly (see Koehl, 2019b) possibly representing the left-laterally offset (Koehl, 2019a, 2019b, 2020) continuation of the core complex in Hornsund-Adriabukta, the proposed scenario is probably more robust than explanations exclusively based on "structural field observations and mapping" (Dr. Piepjohn's comment 284) of poorly exposed and inaccessible outcrop transects. Comment 285: disagreed. This alternative is based on aeromagnetic data from the Geological Survey of Norway covering all Spitsbergen, including the Adriabukta and Påskefjellet areas (Koehl, 2019b). In addition, evidence for core complexes in other areas of Spitsbergen include field structural and geochronological data in northwestern Spitsbergen (Braathen et al., 2018a, 2020), and aeromagnetic and seismic data in central Spitsbergen (Koehl, 2019a, pp. 64, 2019b, 2020). The (restored) pre-Pennsylvanian normal kinematics of the Mariekammen Shear Zone (figure 5 in the manuscript), the presence of Proterozoic basement lenses along the Mariekammen Shear Zone (Bergh et al., 2011), and the absence of the Marietoppen Formation between the Adriabukta Formation and Proterozoic basement over the southwards (left-laterally offset) continuation of the basement high in Hornsund, can be explained by exhumation of this basement high in the Devonian. Since Devonian core complexes of the same trend were documented in northwestern (Braathen et al., 
2018a, 2020) and central Spitsbergen (Koehl, 2019a, 2020, pp. 53-64), it is probable that the basement ridge in Hornsund also exhumed as a core complex. Comment 286: yes, there are. Evidence include structural field mapping of the subvertical WNW-ESE-striking Vimsodden-Kosibapasset Shear Zone of possible Timanian age (Majka et al., 2008,2010; Mazur et al., 2009) and its mapping in Hornsund and in Storfjorden on aeromagnetic and seismic data (Koehl, 2019a, 2019b, 2020, pp. 120144; Koehl et al., in prep. b). Because of the recent discovery of WNW-ESE-striking inherited Timanian faults in Svalbard, this fault is not yet on published geological maps. Comment 287: this means that Chorowicz $(1992)$, Roy $(2007,2009)$ and Roy et al. (unpublished) documented the existence of extensional detachment-related folding within Devonian strata of the Andrée Land Group in Andrée Land. Comment 288: disagreed. The author of the present manuscript uses analog structures in other places around the world that he, himself (in California), or collaborators (Em. Prof. Fried Schwerdtner; University of Toronto) have investigated in the field. The author of the present manuscript also examples from the literature and various geophysical data to compare the structures observed by himself and previous workers (in the present sentence, Dallmann, 1992, his figure 4a) in Spitsbergen. The present manuscript is based on (a) 133 measurements at the Pyramiden locality collected by the author of the present manuscript, (b) 225 measurements of bedding surfaces from Bergh et al. (2011) in Adriabukta that support the similarity of folds within Devonian-Mississippian and post-Mississippian strata, (c) 89 measurements of bedding surfaces and fold axes from Dallmann (1992) in Røkensåta and Hornsund showing subhorizontal, NNW-SSE-trending fold structures in both Devonian and post-Devonian sedimentary strata that trend parallel to fold structures of Bergh et al. in Adriabukta (2011), and (d) 70 and (e) 3756 measurements of bedding surfaces and fold axes and associated cleavage respectively by McCann (2000) in Raudfjorden and Piepjohn (1994) in Dickson Land, Andrée Land, Woodfjorden, Liefdefjorden, Reinsdyrflya and Haakon VII Land (published in Piepjohn, 2000, his figure 5 and in Dallmann and Piepjohn, submitted, their figures 19, 20, 21, 22 and 24), i.e., from both the Dickson

Interactive comment
Printer-friendly version

Discussion paper

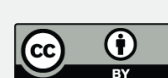


Land and Germaniahalvøya Fold-and-Thrust Zones, showing (in all these areas) subhorizontal, overall NNW-SSE- to N-S-trending fold axes and associated cleavage, all of which trend (sub) parallel to and display similar subhorizontal geometries to Eurekan fold structures and cleavage in both Devonian and post-Devonian rocks in southern Spitsbergen (see Dallmann, 1992 and Bergh et al., 2011 for comparison) but interpreted as Ellesmerian by Dr. Piepjohn. These thousands of (actually 4273) measurements all show that fold structures in Devonian rocks in northwestern and central Spitsbergen are comparable in trend and geometry to those in both Devonian and post-Devonian sedimentary rocks in southern Spitsbergen, and, therefore, that all fold structures in all post-Caledonian sedimentary strata throughout Spitsbergen most likely formed during the same tectonic event: Eurekan deformation. In addition, the present manuscript combines these field measurements to various datasets such as petrological, seismic, and exploration well data. Comment 289: agreed. The sentence is not clear enough. The author of the present manuscript agrees with Dr. Piepjohn in that the folds in Adriabukta (at least partly) result from contractional-transpressional (Eurekan) deformation, but argue that some of them might even have initiated as transtensional folds along (a) low-angle extensional detachment(s) if the model of Devonian-Mississippian core complex exhumation in Hornsund is confirmed (i.e., if the Mariekammen is a pre-Pennsylvanian structure as argued by Bergh et al., 2011). Comment 290: agreed. Comment 291: agreed. Comment 292: agreed. Comment 293: disagreed. The publication is indeed from 2001. Dr. Piepjohn might confuse this contribution with another one by the same authors about the same topic (Saalmann and Thiedig, 2000) published in Polarforschung. Comment 294: agreed. Comment 295: agreed. Comment 296: agreed. Comment 297: the figure caption is not the appropriate place to discuss whether the contacts are faulted or stratigraphic unconformities/conformities. As indicated in the results and discussion chapters, they are most likely partly tectonized stratigraphic unconformities/conformities, but this involves some uncertainty since the outcrops, e.g., between Devonian dark sandstone and uppermost Deovnian-Mississippian strata of the Billefjorden Group above the mine 
entrance are exposed as partly loose blocks (cf. present manuscript lines 354-362). Comment 298: agreed. This contact is partly tectonized by Eurekan deformation as shown in figure $3 \mathrm{~b}$ (in the manuscript) and possibly partly a stratigraphic unconformity, which is more uncertain since such unconformity is covered by screes. Comment 299: fracture surfaces refer to brittle deformation surfaces. Very few slickensides of poor quality were observed. Comment 300: see reply to comment 299. Comment 301: see reply to comment 299. Comment 302: agreed. Poorly written sentence. Comment 303: disagreed. The author of the present manuscript has always been advized to use "surface" instead of "plane". Comment 304: disagreed. See reply to comment 288. Comment 305: disagreed. Figure $3 \mathrm{c}$ in the manuscript is definitely very relevant for the conclusions of the present manuscript (see also reply to Dr. Piepjohn's comment 50 and Figures 15-25). Comment 306: agreed. Comment 307: potential Devonan rocks east of the Billefjorden Fault Zone are shown in figure $4 \mathrm{~g}$ in the present manuscript and described in section in the present manuscript (lines 394-399). Comment 308: agreed. See reply to comment 13. In addition, the seismic sections in figure 4 in the manuscript are attached as supplements uninterpreted. Comment 309: agreed. In a NE-SW-trending seismic section, if a brittle fault or other plane is clearly visible, then it is very likely that this plane intersects the seismic section at a very high angle, i.e., close to $90^{\circ}$, i.e., trending NW-SE perpendicular to the seismic section. If a structure were to intersect a seismic section at a low-angle, it would most likely not be visible and may create some artifacts (e.g., diffraction rays) and/or disruptions. Comment 310: agreed. Comment 311: disagreed. The seismic section in question is composed of a NE-SW-trending segment bending southwards into an east-west-trending segment. The "NE-west" (Northeast to west) term was used to avoid lengthening the figure caption (and the manuscript). The author of the present manuscript is, of course, open to changes that might be suggested by the journal team and the editor. Comment 312: agreed. Comment 313: agreed. Not stated clearly enough. Comment 314: agreed. Comment 315: agreed. However, the present figure does not attempt to show internal deformation pattern within the Lower-lowermost Upper Devonian succession of the 
Andrée Land Group/Mimerdalen Subgroup, which (as Dr. Piepjohn mentions it) is deformed (tilted/folded). The figure focuses on deformation features within the Billefjorden Group. Comment 316: disagreed. The little sketches in figure $6 \mathrm{e}$ in the manuscript are, indeed, taken from sketches in figure $6 \mathrm{~d}$. These show that the inconsistencies along the Billefjorden Fault Zone (variations in the juxtaposed units, kinematics, and fault geometries; discussed lines 879-900 in the present manuscript) can be explained with a tectonic model involving only Devonian-Carboniferous extension and early Cenozoic strain partitioning and decoupling, i.e., thus showing that Ellesmerian deformation is not required to explain structures geometries and kinematics in Dickson Land west of the Billefjorden Fault Zone. Comment 317: agreed. Comment 318: the author of present manuscript is uncertain about which scientific evidences the " $2.5 \mathrm{~km}$ " estimate of Dr. Piepjohn (his comment 318) for the thickness of the Lower-lowermost Upper Devonian succession west of the Balliolbreen Fault is based on his attached figure 3 (his comment 62). Looking at Dr. Piepjohn's figure, a thickness c. 0.5-1 kilometer thickness may be inferred for the Devonian succession directly west of the Balliolbreen Fault (see Dr. Piepjohn's comment 62). The author of the present manuscript agrees with Dr. Piepjohn in that "the basement underneath the Devonian west of the Balliolbreen Fault [might not have been] exposed in the Devonian", which is why basement rocks are (almost completely) covered by Lower-lowermost Upper Devonian sedimentary strata in figure $6 \mathrm{a}$ in the manuscript. Comment 319: agreed. However, see reply to comment 315. Comment 320: agreed. Comment 321: west of the Triungen-Grønhorgdalen Fault Zone, Lower Devonian rocks of the Wood Bay Formation were gently folded in early Cenozoic times. Comment 322: agreed. The author of the present manuscript bases his interpretation on data and observations by Bergh et al. (2011) and added two alternative models to explain the incorporation of basement lenses along the Mariekammen Shear Zone in the Adriabukta. Comment 323: agreed. Yes, it means that the core complex was active from Early Devonian times to Mississippian. Such an activity is supported by geochronological dating of core complex activity in northwestern Spitsbergen (Braathen et al., 2018a) and by 
aeromagnetic data and seismic data in Hornsund and Storfjorden (Koehl, 2019a, 2019b, 2020; Koehl et al., in prep, b). The present manuscript presents geological evidence in favor of a core complex hypothesis, including the restoration of the Adriabukta section transect (figure 5 in the manuscript), potential reinterpretation of pre-Pennsylvanian kinematics along the Mariekammen Shear Zone after restoration (normal movements), the absence of the Marietoppen Formation between Proterozoic basement rocks and the Adriabukta Formaton in Påskefjellet along the southern continuation of the basement high, evidences (including field measurements; see reply to Dr. Piepjohn's comment 288) that presumed Ellesmerian folds within the Marietoppen and Adriabukta formations are not different in trend and geometry from Eurekan folds in overlying, post-Mississippian sedimentary units (see Bergh et al., 2011, their figures $8 \mathrm{~b}$ and $9 \mathrm{a}$ ) and, therefore, are most likely Eurekan as well, and possible explanations (mechanisms) for the presence of a basement lens within the Adriabukta Formation in Adriabukta (figure $7 \mathrm{~b} 1$ and b2 in the manuscript). The core complex model is one way to reconcile all the structural measurements, field observations, and restorations. However, should the claim of Dr. Piepjohn that the Mariekammen Shear Zone is actually early Cenozoic in age be verifiable (i.e., if the von Gosen and Piepjohn, 2001 , study is made available to the author of the present manuscript), Devonian core complex exhumation may not be needed to explain the pre-Pennsylvanian (restored) normal kinematics of the shear zone. Comment 324: The author of the present manuscript simply argues (using figure $7 \mathrm{~b} 1$ and $\mathrm{b} 2$ and based on the reinterpreted normal kinematics of the Mariekammen Shear Zone; figure 5 in the manuscript) that the presence of a basement lens within the Adriabukta Formation is compatible with core complex exhumation. Comment 325: disagreed. B2a, B2b and B2c explain the application of excisement and incisement processes Dr. Piepjohn is asking about in comment 326, detailing how a basement lens may have been ripped off a basement culmination along an extensional low-angle Devonian detachment/normal fault. These processes are detailed in Lister and Davis (1989) and are discussed in the present manuscript lines 1179-1187. Comment 326: see reply to comment 325. Comment

Printer-friendly version

Discussion paper
Interactive

comment

\section{Discussion paper}

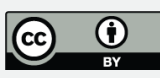


327: agreed. There may be other alternatives to the model of core complex discussed in the present manuscript, e.g., that of a simple basement high (major Caledonian fold?) along which the Hornsund Devonian succession may have deposited. However, the reinterpreted (normal) kinematics along the Mariekammen Shear Zone (figure 5 in the manuscript) favor active pre-Pennsylvanian normal movements along similar moderately dipping faults and shear zones. Comment 328: agreed. However, this was suggested by Dallmann (1992) for the Adriabukta Hornsundeneset formations in Haitanna.

Changes implemented Comment 1: none. Comment 2: none. Comment 3: none. Comment 4: none. Comment 5: none. Comment 6: none. Comment 7: none. Comment 8: none. Comment 9: none. Comment 10: none. Comment 11: shortened the manuscript in various places. Deleted "(e.g., Pyramiden-Odellfjellet)" line 37. Rewrote "The uncertain relationship of the Balliolbreen Fault with uppermost Devonian-Mississippian sedimentary strata, the poorly constrained nature of the contact (unconformity or bedding-parallel décollements and thrusts?) between Lower Devonian and uppermost Devonian-Mississippian sedimentary strata, and along strike variations in cross-section geometry, offset stratigraphy, and inferred timing and kinematics along the Balliolbreen Fault suggest that this fault" into "The present study also shows that the Balliolbreen Fault may" lines 39-44. Deleted "an episode of (Ellesmerian)" line 75. Deleted "in central Spitsbergen" line 83. Deleted "Contractional structures in uppermost Devonian-Mississippian coal seams and shales of the Billefjorden Group are compared to undeformed overlying Mississippian clastic sedimentary deposits in Pyramiden (present study) and Odellfjellet (Koehl and Muñoz-Barrera, 2018; Figure1b)." lines 83-86. Deleted ", notably off the coasts of Alaska and northeastern Russia (Endicott Group), and of northern Canada (Emma Fiord Formation)" lines 112-113. Deleted "(Piepjohn, 2000)" line 177. Deleted "event" line 255. Deleted "; Dallmann et al." line 260. Deleted ", and satellite images" line 302. Deleted "(Figure 1a-b)" lines 438, 475. Changed "fault splays" into "faults" line 503. Changed "c, $d$ and e" into "c-e" line 447. Deleted "tightly" line 598. Deleted "Cenozoic" lines 609 and 642. 
Deleted "Pyramiden (Figure 3b)" line 646. Deleted "Cenozoic" line 664. Deleted "sedimentary" line 734 and "the need of "line 737. Deleted "outcrops" line 878. Deleted "," and "possibly" line 879. Changed ". This fault represents a potential analog to the Billefjorden Fault Zone and" into ", which “. Deleted "the Triungen-Grønhorgdalen Fault Zone might, just as the Billefjorden Fault Zone in Pyramiden, have accommodated the deposition of thickened, coal-rich sedimentary deposits (Livshitz, 1966; Cutbill et al., 1976), thus making" lines 932-934. Deleted "green "line 1001. Changed "correspond to" into "be" line 1005. Deleted "in the Late Devonian-Mississippian" lines 1032-1033. Deleted "western (Andresen, 2009) and" line 1151. Deleted "further" line 1338. Deleted "(3) obtaining accurate time constraints (Late Devonian? Mississippian?) for the deposition of sedimentary rocks of the Adriabukta Formation," lines 1344-1346. Shortened "transitions from red and green Lower Devonian sandstone (Wood Bay Formation) to Devonian quartzite and dark sandstone (dashed orange), from Devonian quartzite and dark sandstone to uppermost Devonian-Mississippian sedimentary rocks of the Billefjorden Group (dashed yellow green), and from the Billefjorden Group to strata of the Gipsdalen Group (dashed blue green)" into "transitions" lines 1961-1966. Deleted "showing approximate contacts between Lower Devonian red and green sandstone and Devonian quartzite and dark sandstone in dashed orange, between Devonian quarzite and Devonian dark sandstone in dotted orange, between Devonian dark sandstone and uppermost Devonian-Mississippian strata of the Billefjorden Group in dashed yellow green, and between the sedimentary rocks of the Billefjorden Group and Gipsdalen Group in dashed blue green" lines 1979-1984. Comment 12: none. Comment 13: improved the quality of all the figures in the manuscript. Comment 14: none. Comment 15: none. Comment 16: none. Comment 17: none. Comment 18: none. Comment 19: none. Comment 20: none. Comment 21: added "Mimerdalen Subgroup" line 162, "of the Andrée Land Group and Mimerdalen Subgroup" lines 23, 24-25, 3435, 66-67, 93, 146-147, 188-189, 225, 646, 655, 668, 687-688, 689-690, 741-742, 766, 817-818, 951-952, 967-968, 970, 1018-1019, 1219-1220, 1329-1330, 13321333, 1352-1353, 1361-1362, 1380, 2105-2106, "of the Andrée Land Group and/or 
Mimerdalen Subgroup" lines 375-376, 593-594, 833-834, "of the Gipsdalen Group" line 647, "Lower" lines 746, 750, 793, 796, 811, 813, 896, 898, 917, 936, 2027, 2044, "(Lower-lowermost Upper?)" lines 770, 772, 1069, 1127, "Middle" lines 154, 1147, 1150, 1155, 1164, "of the Billefjorden Group" lines 1330-1331, "uppermost" line 94, "-Permian" line 94, and delete "post-" line 94 Comment 22: none. Comment 23: none. Comment 24: none. Comment 25: none. Comment 26: none. Comment 27: none. Comment 28: none. Comment 29: none. Comment 30: none. Comment 31: none. Comment 32: none. Comment 33: none. Comment 34: none. Comment 35: none. Comment 36: none. Comment 37: none. Comment 38: none. Comment 39: none. Comment 40: none. Comment 41: none. Comment 42: none. Comment 43: none. Comment 44: see reply to comment 13 . Comment 45: none. Comment 46: none. Comment 47: improved figure quality. Thickened the arrows and enlarged the localities abbreviations in figure 1 in the manuscript. Comment 48: improved figure quality. Enlarged the geological symbols and thickened the lines. Added legend within Figure 2 in the manuscript. Comment 49: improved figure quality. Added uninterpreted field photograph of figure $3 \mathrm{~b}$ as supplement $\mathrm{S} 4$. Added "See supplement 4 for uninterpreted photograph." line 1993. Enlarged text and symbols of measurements in figure $3 a$ in the manuscript. Added legend for yellow and red lines in figure $3 b$ into figure 3b. Comment 50: attached interpreted and uninterpreted field photographs of the Triungen locality to the present discussion (e.g., Figures 15-25), some of which may be added to the manuscript's supplements in accordance with recommendation from the journal. Comment 51: see reply to comment 13. Comment 52: added " (see Fig. 1 for location of Adriabukta)". Added "presumably" line 14. Deleted "Late Devonian" and "?)" line 157. Changed "(time equivalent of the upper Andrée Land Group; Birkenmajer and Turnau, 1962; Birkenmajer, 1964; Cutbill and Challinor, 1965; Dallmann et al., 1993a; Bergh et al., 2011)." into ".Palynological studies by Birkenmajer and Turnau (1962) show that the Adriabukta Formation includes Lycospora and Tripartites/Triquitrites, which strongly suggest a lowermost Visean (Mississippian) age for this stratigraphic unit, i.e., time equivalent to the Billefjorden Group (Birkenmajer, 1964;

Printer-friendly version

Discussion paper
Interactive

comment

\section{D}

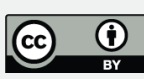


Cutbill and Challinor, 1965). However, based on structural correlation between presumed Ellesmerian structures in the Adriabukta Formation and presumed Ellesmerian fold-and-thrust belts in central-northern Spitsbergen, Dallmann et al. (1999), Bergh et al. (2011) and Dallmann and Piepjohn (2014, submitted) argue that the Adriabukta Formation is probably Late Devonian in age and the time equivalent of the upper Andrée Land Group or Mimerdalen Subgroup." lines 155-156. Replaced "Upper Devonian-“ by "(Upper Devonian?-)" lines 200, 1095, 1106, 1113, 1130-1131, 1185, 2046-2047, and 1121. Changed "Upper Devonian (-Mississippian?)" line 534-535 and in figure 7b into "(Upper Devonian?-) Mississippian". Added "Another major inconsistency around the timing of Ellesmerian deformation in Spitsbergen, which must have terminated by mid-Fammenian times when sedimentary strata of the Billefjorden Group started depositing in Dickson Land (Lindemann et al., 2013; Marshall et al., 2015), is the debate about the age of the Adriabukta Formation. Birkenmajer and Turnau (1962) dated black shales at the base of the Adriabukta Formation to the lowermost Visean based on spore assemblages. This age is considered doubtful by various structural studies because of the tentative structural correlations between fold and thrust structures in the Adriabukta Formation with analogous structures in rocks of the Andrée Land Group and Mimerdalen Subgroup in central and northern Spitsbergen (e.g., Dallmann et al., 1999; Bergh et al., 2011; Dallmann and Piepjohn, submitted). However, these correlations are only speculative and the palynological ages obtained by Birkenmajer and Turnau (1962) are actually robust due to the presence of Lycospora, Tripartites and Triquitrites (typical in Visean spore assemblages; Hughes and Playford, 1961; Playford, 1962, 1963; Clayton et al., 1977; Lopes et al., 2018a, 2018b). This suggests that the Adriabukta Formation is indeed Mississippian (Visean) in age and that folds and thrusts in this unit are all early Cenozoic in age, thus strongly supporting that the relatively more intense deformation pattern observed within the Adriabukta Formation is related to strain partitioning and decoupling of Eurekan deformation due to the abundance of rheologically weak shales in this Formation." line 1119. Changed "Late Devonian" into "(Late Devonian-) Mississippian" lines 1122 and 1126. Added "Mississippian" line

Interactive comment
Printer-friendly version

Discussion paper

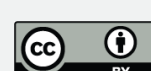


553. Changed “(Upper Devonian-Mississippian?) Adriabukta and (Lower-Middle Devonian)" into "(Upper Devonian?-) Mississippian Adriabukta and Lower-Middle Devonian" lines 1163-1164. Changed "Devonian (-Mississippian?)" into "Middle DevonianMississippian" line 1175. Added "Middle" and "Late" line 1186 and in figure 5 in the manuscript. Added "-Mississippian" lines 1189. Deleted "(3) obtaining accurate time constraints (Late Devonian? Mississippian?) for the deposition of sedimentary rocks of the Adriabukta Formation," lines 1344-1346. Changed "(4)" into "(3)" line 1346 and "(5)" into "(4)" line 1349. Added "Most grateful thanks to Prof. John Marshall (University of Southampton), Dr. Christopher Berry (University of Cardiff), Dr. Gilda Lopes (University of Algarve), and Prof. Gunn Mangerud (University of Bergen) for their help with the palynology of Devonian-Mississippian rocks in Spitsbergen." line 1362. Changed "Upper Devonian-Mississippian (Adriabukta Fm.)" in figure 5 into "(Upper Devonian?) Middle Mississippian". Changed "Late Devonian (-Mississippian?)" in figure 7b into "(Late Devonian?-) Middle Mississippian" and "Mississippian" in figure 7c into "Late Mississippian". Added "Late" line 2053. Added Hughes and Playford (1961), Playford (1963), Clayton et al. (1977), and Lopes et al. (2018) to the reference list. Added " , Part 1" line 1838. Comment 53: none. Comment 54: none. Comment 55: added "BF?", arrow and potential southwards continuation of the possible Balliolbreen Fault as a red dashed line in figure 2 in the manuscript. Comment 56: none. Comment 57: improved figure quality and added "(from the present contribution and by previous workers)" lines 2111-2112. Comment 58: none. Comment 59: see reply to comment 53. Comment 60: added Bælum and Braathen (2012), Dallmann and Maher (1989), Frodsham and Gayer (1999), Gawthorpe and Leeder (2000), Haremo et al. (1990), Koehl et al. (in prep.), Lamar and Douglass (1995), Piepjohn and von Gosen (2017), Prosser (1993), Schlische (1995), Welbon et al. (1992, unpublished), Wilson and Wojtal (1986), and Worsley and Mørk (1978) to the reference list, and deleted Steel and Worsley (1984) and Thomas (2002) from the reference list. Also corrected Gawthorpe and Leeder (2003) lines 443-444, and "van" into "von" line 61. Comment 61: none. Comment 62: none. Comment 63: none. Comment 64: none. Comment

Interactive comment
Printer-friendly version

Discussion paper \\ 162}


65: deleted ", and juxtaposition of undeformed Mississippian-Permian strata against intensely folded Devonian rocks" lines 17-18. Added "Later on, presumed Ellesmerian structures were unconformably covered by uppermost Devonian-Permian sedimentary deposits of the Billefjorden Group and Wordiekammen Formation." line 17. Comment 66: changed "Wördiekammen" into "Wordiekammen". Comment 67: none. Comment 68: none. Comment 69: none. Comment 70: none. Comment 71: added "and/or decoupling" line 46. Comment 72: added ", " and "-Mississippian" line 47. Comment 73: changed "fault geometries and (differential) deformation within Devonian-Permian sedimentary strata in" into "differential deformation between Lower-lowermost Upper Devonian rocks of the Andrée Land Group/Mimerdalen Subgroup and overlying uppermost Devonian-Permian sedimentary strata of the Billefjorden and Gipsdalen groups in central-northern Spitsbergen, and between Lower Devonian-Middle Mississippian rocks of the Marietoppen and Adriabukta formations and overlying post-Devonian rocks in southern" line 50. Comment 74: added "Vogt, 1938; Harland et al., 1974; " line 65. Comment 75: replaced "Franklinian basement" by "Proterozoic-lower Paleozoic sedimentary basins and basement rocks" line 56. Comment 76: changed "northerneastern" into "northeastern" line 56. Comment 77: see reply to comment 75. Comment 78: replaced "van" by "von" line 59. Comment 79: added "Lane, 2007; " line 59 and to the reference list. Comment 80: replaced "Precambrian basement units" by "ProterozoicSilurian metasedimentary rocks" line 60. Comment 81: added "northern-" line 60. Comment 82: none. Comment 83: none. Comment 84: added "northern-“ line 63. Comment 85: added "Vogt, 1938; Harland et al., 1974; " line 65. Comment 86: none. Comment 87: none. Comment 88: added "Vogt, 1938; Harland et al., 1974; " line 82. Comment 89: none. Comment 90: none. Comment 91: added "(McWhae, 1953; Harland et al., 1974)" line 94. Comment 92: none. Comment 93: added "see locations in "line 96. Comment 94: changed "Northeast" into "northeastern" line 100. Comment 95: added "et al." line 101. Comment 96: replaced "northeastern" by "northernnortheastern" line 104. Comment 97: none. Comment 98: changed "northeastern" into "northern" line 105. Comment 99: none. Comment 100: none. Comment 101: 
none. Comment 102: none. Comment 103: added "Siktefjellet "line 139, "(Gee and Moody-Stuart, 1966; Friend et al., 1966; Friend and Moody-Stuart, 1972; Murascov and Mokin, 1979; Friend et al., 1997) " line 140, and Gee and Moody-Stuart (1966), Friend et al. (1966), Murascov and Mokin (1979) and Friend et al. (1997) to the reference list. Comment 104: none. Comment 105: none. Comment 106: none. Comment 107: none. Comment 108: none. Comment 109: added "Roy, 2007; " line 1184. Comment 110: none. Comment 111: none. Comment 112: none. Comment 113: replaced "contraction" by "deformation" line 159. Comment 114: added "-Early Mississippian" line 159. Comment 115: none. Comment 116: added "Vogt, 1938; "line 167. Comment 117: none. Comment 118: none. Comment 119: changed "contraction" into "deformation" line 177 and deleted "(Piepjohn, 2000)" to avoid repetition of this reference in the same sentence. Comment 120: added "McCann, 1993; McCann and Dallmann, 1996; Michaelsen et al., 1997; Michaelsen, 1998" line 178. Comment 121: none. Comment 122: none. Comment 123: changed "Wördiekammen" into "Wordiekammen". Comment 124: changed "Mlchaelsen" into "Michaelsen" line 182. Comment 125: see reply to comment 13. Comment 126: none. Comment 127: see reply to comment 123. Comment 128: none. Comment 129: changed "speculative" into "tentative" line 193. Comment 130: moved reference to "Bergh et al., 2011" line 196. Added "Birkenmajer, 1964" line 196. Comment 131: changed "The main argument for Ellesmerian tectonism in southern Spitsbergen is" by "The main arguments for Ellesmerian tectonism in southern Spitsbergen are folded Devonian strata unconformanly covered by Triassic strata in Røkensåta (Dallmann, 1992, his figure 4a) and" line 197. Comment 132: none. Comment 133: none. Comment 134: changed "Austfjorden" into "Odellfjellet" line 221. Also, the figure quality will be improved. Comment 135: changed "2019" into "2018" line 235 and in the reference list. Comment 136: see reply to comment 123. Comment 137: added "normal" between "scale" and "displacement" lines 249250. Comment 138: see reply to comment 123. Comment 139: none. Comment 140: changed "transpression" by "deformation" line 256. Also replaced "contraction" by "deformation" lines 48, 76, 159, 164, 177, 269, 654, 855, 958, 1047, 1066, 1083, 1087, 
1088, 1158, 1224, 1236, 1329, and 2058. Added “-transpression" lines 190, 571, 737, and 985. Changed "Caledonian contraction" into "the Caledonian Orogeny" line 657. Changed "transpression" into "deformation" lines 925, 998 and 1137. Comment 141: none. Comment 142: none. Comment 143: none. Comment 144: see reply to comment 140. Comment 145: deleted "erosion exposed" line 291 and added "are exposed" at the end of the sentence line 292. Comment 146: added "Birkenmajer, 1964; Dallmann, 1992; " line 292. Comment 147: none. Comment 148: none. Comment 149: changed "an east-verging fold" into "a large fold structure" line 307. Changed "with locally overturned eastern limb" into "with Devonian bedding surfaces locally overturned to the east". Comment 150: see reply to comment 149. Comment 151: replaced "Hecla Hoek" by "Proterozoic basement rocks" line 312. Comment 152: added "showing quartz crystals resembling pyroxenes" line 317. Comment 153: none. Comment 154: added "The presence of abundant coal suggests that this one-two meters thick unit is part of the Billefjorden Group as well." line 324. Comment 155: changed "Insay" into "Insley" lines 88, 554, and 1757. Comment 156: see reply to comment 154. Comment 157: none. Comment 158: none. Comment 159: none. Comment 160: none. Comment 161: added "of the Andrée Land Group" line 394. Comment 162: none. Comment 163: deleted "or their time-equivalent in southern Spitsbergen, the Marietoppen Formation" lines 398-399 and added "(or time-equivalent Marietoppen Formation in southern Spitsbergen)" line 398. Comment 164: see reply to comment 123. Comment 165: see reply to comment 123 . Comment 166: see reply to comment 123. Comment 167: see reply to comment 13 . Comment 168: see reply to comment 123. Comment 169: see reply to comment 123 . Comment 170: see reply to comment 123. Comment 171: see reply to comment 123. Comment 172: none. Comment 173: see reply to comment 162 . Comment 174 : none. Comment 175: see reply to comment 123. Comment 176: see reply to comment 123 . Comment 177 : see reply to comment 123. Comment 178: none. Comment 179: none. Comment 180: none. Comment 181: see reply to comment 123 . Comment 182 : see reply to comment 123 . Comment 183: none for the moment. Awaiting more information from Solid Earth. Comment

Printer-friendly version

Discussion paper
Interactive comment

\section{Discussion paper}

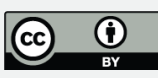


184: changed "St-Jonsfjorden" into "St. Jonsfjorden" line 565. Comment 185: added "in Pyramiden" line 569. Comment 186: see reply to comment 140. Comment 187: none. Comment 188: none. Comment 189: deleted ",e.g., in the Hikurangi subduction margin in New Zealand" lines 585-586 and added "e.g.," line 586. Comment 190: see reply to comment 13. Comment 191: none. Comment 192: none. Comment 193: see reply to comment 13. Comment 194: added "-Barrera" line 619. Comment 195: see reply to comment 140. Comment 196: none. Comment 197: none. Comment 198: added " in the SW Barents Sea," line 631. Comment 199: none. Comment 200: added "Aakvik, 1981; " lines 225-226 and 230, and to the reference list. Comment 201: none. Comment 202: added "exclusively" line 650. Comment 203: none. Comment 204: see reply to comment 123 . Comment 205: changed "Backward-dipping duplexes in Pyramiden are located along the eastern limb of a major N-S-trending fold in Devonian sedimentary rocks (Error! Reference source not found.), thus far ascribed to the Ellesmerian Orogeny (Piepjohn, 2000; Bergh et al., 2011)." into "Backward-dipping duplexes in Pyramiden are juxtaposed against east-dipping (and locally overturned westdipping) Devonian strata of the Andrée Land Group/Mimerdalen Subgroup (Figures 2 and $3 a$ and $b$ in the manuscript) adjacent to and showing similar attitude to major fold structures in Mimerdalen thus far ascribed to the Ellesmerian Orogeny (Vogt, 1938; Piepjohn, 2000; Bergh et al., 2011)." lines 680-682. Comment 206: none. Comment 207: none. Comment 208: none. Comment 209: rewrote "(Carboniferous sedimentary strata) remains essentially the same, whereas the length of the floor sequence (Devonian sedimentary rocks) decreases through intense folding (Bonini, 2001), which may (partially) explain the significant 735 differences of deformation between folded Devonian and Mississippian-Permian strata" into "(uppermost Devonian-Permian sedimentary strata) remains essentially the same, whereas the length of the floor sequence (Lower-lowermost Upper Devonian rocks of the Andrée Land Group and Mimerdalen Subgroup) decreases through intense folding (Bonini, 2001), which may (partially) explain the significant differences of deformation between folded Lower-lowermost Upper Devonian of the Andrée Land Group/Mimerdalen Subgroup, strongly sheared upper-

\section{C166}

Interactive

comment
Discussion paper
Printer-friendly version

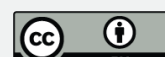


most Devonian-Mississippian strata of the Billefjorden Group, and poorly deformed to gently tilted uppermost Devonian-Permian strata of the Billefjorden and Gipsdalen groups" lines 733-736. Comment 210: replaced "model in" by "interpretation is" line 748. Comment 211: none. Comment 212: none. Comment 213: none. Comment 214: none. Comment 215: see reply to comment 55. Also added "The moderate- to lowamplitude character of internal seismic reflections within this seismic unit suggests that it is made up with relatively homogeneous deposits with minor lithological variations. Thus, " line 395. Comment 216: added "(Harland et al., 1974; Lamar et al., 1982, 1986; McCann, 1993; Lamar and Douglass, 1995)" line 829. Comment 217: none. Comment 218: deleted "," and "possibly" line 879. Added "in the hanging wall" and "rocks in the footwall" line 890. Comment 219: see reply to comment 123. Comment 220: see reply to comment 123 . Comment 221 : see reply to comment 123 . Comment 222: changed "in this area, e.g., in Yggdrasilkampen where" into "in this area. For example, in Yggdrasilkampen," line 906. Comment 223: none. Comment 224: none. Comment 225: deleted "Fig. " line 923. Also see reply to comment 13. Comment 226: none. Comment 227: none. Comment 228: none. Comment 229: none. Comment 230: see reply to comment 13 . Comment 231: see reply to comment 123 . Comment 232: none. Comment 233: none. Comment 234: none. Comment 235: added "and Raudfjorden" and "angular " line 953, and "within sedimentary units within the Red Bay Group (Braathen et al., 2020), and" line 955. Comment 236: none. Comment 237: none. Comment 238: none. Comment 239: see reply to comment 123. Comment 240: see reply to comment 13 . Also added "as a dotted black line" line 973. Comment 241: none. Comment 242: see reply to comment 123. Comment 243: see reply to comment 13. Rewrote "Figure 1b" into "see Figure 1b for location" line 976. Comment 244: none. Comment 245: see reply to comment 123. Comment 246: see reply to comment 123. Comment 247: none. Comment 248: see reply to comment 123. Comment 249: see reply to comment 123. Comment 250: deleted "Piepjohn (2000) and " and added ", their figure 14a" line 988. Comment 251: see reply to comment 123 . Comment 252: none. Comment 253: see reply to comment 140 . Comment 254: see reply to comment

Interactive comment
Printer-friendly version

Discussion paper

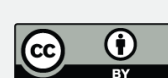


123. Comment 255: none. Comment 256: none. Comment 257: see reply to comment 123. Comment 258: none. Comment 259: none. Comment 260: none. Comment 261: changed "2015" into "2016" line 1038. Comment 262: none. Comment 263: changed "(Piepjohn and Dallmann, 2014)" into "discussed by Piepjohn and Dallmann (2014)" lines 1041-1042. Comment 264: changed "breccia" into "karst infill” lines 1045, 1047, 1048, 1051, 1054. Comment 265: none. Comment 266: none. Comment 267: none. Comment 268: none. Comment 269: none. Comment 270: none. Comment 271: none. Comment 272: none. Comment 273: none. Comment 274: none. Comment 275: changed "(Figure 1a)" into "see Figure 1a for location" line 1135. Comment 276: none. Comment 277: none. Comment 278: none. Comment 279: none. Comment 280: none. Comment 281: none. Comment 282: none. Comment 283: changed "Haitana (Figure 1a)" into "Haitanna (see Figure 1a for location)" line 1187. Comment 284: none. Comment 285: none. Comment 286: none. Comment 287: none. Comment 288: none. Comment 289: rewrote "A formation as transtensional folds of" as "A partial initiation as Devonian-Middle Mississippian transtensional folds of some of the" lines 1209-1210. Added "However, despite a potential partial initiation as DevonianMiddle Mississippian transtensional structures for some of the presumed Ellesmerian folds in southern Spitsbergen, a formation of these folds during Eurekan tectonism is believed to be the most probable scenario." line 1216. Comment 290: replaced "30 pp." by "255-284" line 1404. Comment 291: replaced "2019" by "2018" line 1404. Comment 292: moved the three references by J.-C. L. G. Roy after Roberts (1983) line 1869. Comment 293: none. Comment 294: moved the reference of Schneider et al. (2018) after that of Schmiedel et al. (2017) line 1885. Comment 295: deleted reference to Steel and Worsley (1984) from the reference list lines 1903-1905. Comment 296: thickened dotted orange lines in figure 2 in the manuscript. Comment 297: none. Comment 298: added "(partly covered by screes)" line 336. Comment 299: none. Comment 300: none. Comment 301: none. Comment 302: deleted "lithostratigraphic" line 1979. Comment 303: none. Comment 304: none. Comment 305: none. Comment 306: added "in Two-Way Time (TWT)" line 2002 and "TWT" in figure 4a in the 
manuscript. Comment 307: none. Comment 308: see reply to comment 13. Comment 309: none. Comment 310: see reply to comment 123. Comment 311: none. Comment 312: see reply to comment 123. Comment 313: added "(in the basement lens within the Adriabukta Formation)" line 2025. Comment 314: changed the scale to from "1 km" to "500 m" in figure 5 in the manuscript. Comment 315: added "and its relationship with deformation within the Billefjorden Group" line 2031. Comment 316: none. Comment 317: accentuated the contrast between sheared and undeformed coals in figure 6b-e and legend in the manuscript. Comment 318: none. Comment 319: none. Comment 320: replaced "Odelffjellet" by "Odellfjellet" line 2041. Comment 321: none. Comment 322: none. Comment 323: none. Comment 324: none. Comment 325: none. Comment 326: none. Comment 327: none. Comment 328: removed the onlaps markers within the Adriabukta Formation onto the Marietoppen Formation in figure 7 in the manuscript.

Additional revisions by the author of the present manuscript -Line 16: added "Lowerlowermost Upper" and "of the Andrée Land Group and Mimerdalen Subgroup". -Line 18: added ", petrological, exploration well". -Line 20: added ", which". -Line 21: added “”. -Lines 22, 824, 942, 2037: added "Lower-lowermost Upper “. -Lines 23, 25, 38, 72, 266, 453, 457, 471, 483, 496, 498, 501, 513, 521, 557, 574, 598, 606, 609, 611, $650,661,671,682,719,725,741,847,855,858,892,896,897,904,909,966$, 977, 978, 983, 985, 1008, 1063, 1065, 1115, 1145, 1174, 1297, 1305, 1309, 1319, 2013, 2031: added "early". -Lines 23, 38, 598, 603, 642, 741, 939, 2007: added "Eurekan". -Line 23: added "in Pyramiden, Sassenfjorden-Tempelfjorden and Reindalspasset". -Lines 23-24: deleted "In addition, Devonian strata probably experienced syn-depositional, post-Caledonian, extensional, detachment-related folding.". -Lines 25, 96: added "-Tempelfjorden". -Line 33: changed "have deposited" in to "be preserved". -Line 35: added "and reinterpretation of previous datasets, the". -Lines 3536: changed "juxtaposition of Proterozoic basement rocks against" into "thrusting of Proterozoic basement rocks over". -Line 37: added "a combination of Devonian syndepositional, extensional, detachment-related folding,". -Lines 48, 1218, 1334: added 
"greenschist-“. -Line 55: deleted “, “. -Line 62: added "Vogt, 1938; “. -Line 63: added "and most well-constrained”. -Lines 64, 546, 641, 649, 662, 681, 808, 1007, 1025: added "Lower-lowermost Upper ". -Lines 65, 175, 287, 776, 786, 795: added "uppermost Devonian-“. -Line 70: changed "through" into "throughout". -Line 76: added "Ellesmerian". -Line 80: deleted "Error! Reference source not found.". -Lines 89, 191, 196, 621, 667, 924, 997, 1066, 1099, 1110, 1145, 1153, 1160, 1333, 2019, 2058: added "early" and "Eurekan". -Line 90: added "-gently tilted". -Line 110: changed "However" into "Nevertheless". -Line 135: changed "post-late" into "late-post". -Line 149: changed "in" into "from". -Line 152: replaced "-" by " and ". -Lines 158, 223, 766, 1061, 2036: changed "contraction" into "deformation". -Line 174: added "Harland et al., 1974; “. -Line 176: added "-lowermost Upper". -Line 183: added "-gently dipping". -Lines 184, 926, 993: changed "Carboniferous" into "uppermost Devonian". -Line 187: changed "juxtaposes" into "thrusted" and "against" into "over". -Line 198: changed "m-thick" into "meter-thick". -Line 199: deleted double space. -Lines 200, 539, 1095, 1105, 1113, 1121, 1122, 1126, 1131, 1164, 1175, 1183, 2047: added "Middle". -Lines 210, 1237: changed "Th-U" into "U-Th". -Line 215: added "that deep" and "Potential Ellesmerian greenschist facies metamorphism and mylonitization was also identified in Oscar II Land (Barnes et al., 2020).". -Line 218: changed "km-" into "kilometer-" twice. -Line 230: changed "Steeel" into "Steel”. -Line 261: added ",". -Line 285: added "-depth". -Line 290: changed "km-" into "kiometer-". -Line 293: changed "Cenozoic transpression" into "early Cenozoic Eurekan deformation". -Line 313: changed "were" into "was". -Line 314: added "McCann, 1993; ". -Line 317: delete " a" and changed "section" into "sections". -Line 320: added ", Aakvik (1981)". -Lines 322, 327, 336, 354, 1010: added "Lower". -Line 343-344: added "thick red lines showing the" and replaced ";", by "in“. -Line 354: replaced "wood fossils" by "fossil wood". -Lines 355, 361, 370, 373, 784, 787, 797, 802: added "Lower (-lowermost Upper?) ". -Line 357: deleted "Fig. ". -Line 358: added " or tectonized". -Lines 368-369: added "the ", and replaced "faults" by "fault" and "represent" by "represents". -Line 378: added " and fieldwork". -Line 381: added "along the fault and ". -Line 394: moved "in Reindalspas-

Interactive

comment
Printer-friendly version

Discussion paper

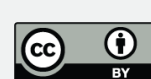


set (Figure 1a-b)" and replaced "display" by "are characterized by". -Line 396: added "of". -Lines 397-398: deleted "-Middle" line 397 and added "Middle Devonian" line 398. -Line 467: added "This interpretation is supported by onshore Eurekan thrust geometries on the northern shore of Sassenfjorden (supplement 5)." and also added Supplement 5 to the supplements. -Lines 476, 508, 586: added "Lower-Middle ". -Line 526: added "upwards", "Lower-Middle" and "downwards". -Lines 527-528: rewrote "tentatively interpreted as the potential" into "interpreted as a Carboniferous normal fault possibly representing the southwards". -Line 550: changed "Cenozoic contraction" into "Eurekan deformation". -Line 556: added ". These structures and geometries are typical in coal deposits reworked by contractional deformation". -Lines 556-557: rewrote "This interpretation" into "The interpretation of bedding-parallel décollements". -Lines 566-567: added "/subhorizontal thrust" and "; Gasser and Andresen, 2013" and added Gasser and Andresen (2013) to the reference list. -Lines 570, 571: changed "early Cenozoic" into "Eurekan". -Line 585: changed "and to analogous structures" into ". The geometries of these duplexes, thrusts and décollements on seismic data in Spitsbergen are similar to analogous structures on seismic data". -Line 588: changed "analog" into "analogous". -Lines 590, 824: changed "presence" into "preservation". -Line 599: deleted parentheses. -Lines 603-604 and 641: changed "Cenozoic transpression" into "'early Cenozoic deformation". -Lines 609, 616, 644, 809, 818, 864, 875, 881, 905, 913, 969, 991, 995, 998, 1005, 1014, 1051, 1057, 1096, 1141, 1143, 1170, 2006, 2009, 2013, 2015: changed "Cenozoic" into "Eurekan". -Line 613: changed "Carboniferous" into "Pennsylvanian". -Line 622: added "further". -Line 626: changed "the Russian" into "Russia". -Lines 643-644: moved "in basinal areas in the hanging wall of the Odellfjellet Fault" from line 643 to line 644. -Line 652: changed "Cenozoic transpression" into "Eurekan deformation" and "soft" by "weak". -Lines 652, 689, 712, 714, 721, 796, 1058, 1106: changed "soft" into "weak". -Line 655: rewrote "might not be required to explain differential deformation between late Paleozoic" into "is most likely not required to explain differential deformation within Lower Devonian to Permian". -Lines 659, 964: added "lowermost". -Line 661: changed "transpression" into "deformation". 
-Line 665: added "and stratigraphic units". -Line 676: added "Noteworthy, a model of critical wedge taper for the West Spitsbergen Fold and Thrust Belt predicted an increasing influence of decoupling (as observed in Pyramiden, Sassenfjorden-Tempelfjorden and Reindalspasset; Figure $3 \mathrm{~b}$ and Figure 4) towards the foreland of the fold and thrust belt, i.e., near the study area in central Spitsbergen (Braathen et al., 1999)... -Line 683: rewrote "rigid buttress that localized" into "relatively rigid buttress, i.e., partly deforming and partly localizing". -Line 685: rewrote "and allowed" into ", and allowing". -Line 694: added ". In Pyramiden, this is supported by drill data from Trust Arktikugol showing that coal seams of the Billefjorden Group at the mine continue eastwards and preserve a gentle-moderate dip to the east (Aakvik, 1981, his figure 8.2.5)". -Line 694: added "interpretation". -Line 698: replaced "ESE" by "east-southeast". -Line 702: added "as a steeply east-dipping fault". -Line 716: changed "soft" into "the weak". Lines 721-723: rewrote "Odellfjellet Fault at depth, which branched off and ramped up into rotated, soft, coal- and coaly shale-dominated syn-rift sedimentary rocks of the Billefjorden Group, forming bedding-parallel décollements (Phillipson, 2003, 2005; Molinda, 2003; Elizalde et al., 2016) and tilted" into "Billefjorden Fault Zone at depth, branching off and ramping upwards into, soft, coal- and coaly shale-dominated synrift sedimentary rocks of the Billefjorden Group, forming bedding-parallel décollements (Phillipson, 2003, 2005; Molinda, 2003; Elizalde et al., 2016) and east-dipping". -Line 731: changed "Mississippian" into "uppermost Devonian". -Line 736: added "(Vogt, 1938; Harland et al., 1974; Piepjohn et al., 1997; Michaelsen et al., 1997; Michaelsen, 1998; Piepjohn, 2000)" and "(Figure 3b)". -Line 739: added "(-lowermost Upper?)". -Line 750: added "see " and "for location". -Line 758: added "(relatively rigid)". -Line 760: changed "Odellfjellet Fault" into "Billefjorden Fault Zone". -Lines 770-771: rewrote "an east-verging fold" into "a fold structure with bedding locally overturned to the east". -Line 774: added "Aakvik (1981),". -Line 797: changed "form" into "localize". -Line 809: added "in the early Cenozoic". -Line 818: added " (BFZ?" in Figure 4g)". -Line 826: added "in Dickson Land". -Lines 829-830: rewrote "geometry variations along strike" into "along-strike variations in geometry". -Line 845: added "black ". -Line 861: 
replaced "Mississippian" by "Billefjorden Group". -Line 881: changed "MississippianPennsylvanian" into "Billefjorden-Gipsdalen groups". -Lines 897-898: added "in the hanging wall". -Line 903: added " (i.e., explaining the presence of numerous WNWESE-trending valleys and glaciers in this part of Dickson Land, such as Svenbreen, Hørbyebreen, Mimerdalen, Odindalen)". -Line 930; changed "thick" into "thickened". -Line 935: rewrote "Cenozoic strain (partial) decoupling relevant for the Triungen area as well. Noteworthy," into "Eurekan (partial) strain decoupling is actually relevant for the Triungen area as well. Notably". -Line 938: changed "thick" into "abundant (tectonically thickened?)". -Line 946: replaced "," by "and". -Lines 947-948: rewrote ", hence, is more likely to correspond" into ". Hence, this fault most likely corresponds". -Line 949: changed "lower" into "upper". -Line 953: added " (Michaelsen, 1998, her figure 39)". -Line 959: added "or (down-west) normal faulting". -Line 961: added "showing normal sense of shear". -Line 962: moved "Michaelsen, 1998" after "McCann and Dallmann, 1996". -Line 967: added "location shown in ". -Line 998: added "local". -Line 999: added "The presence of local Eurekan décollements between rocks of the Andrée Land Group/Mimerdalen Subgroup and of the Wordiekammen Formation in Dickson Land is supported by seismic interpretation in Billefjorden (Koehl et al., in prep.).". -Line 1001: added "Middle-lowermost". -Lines 1002 and 1079: added "Member of the Tordalen". -Line 1040: added "/or" and "detachment/". -Lines 1058-1059: added "were folded" and deleted "were". -Line 1060: changed "remain" into "remained". -Line 1068: replaced "deformation" by "strain". -Line 1073: changed "breccia" into "infill". -Line 1079: added " ; Newman et al., 2019". -Line 1090: changed "and Cenozoic" into "and/or subsequent early Cenozoic Eurekan". -Line 1094: deleted "between". -Line 1096: changed ", and" into "from". -Line 1097: added "Late". -Line 1112: changed "softer" into "weaker". -Line 1117: deleted "Fig. " and in 23 other occurrences throughout the manuscript. -Line 1129: replaced "that" by "since the". -Line 1142: changed "potential" into "potentially". -Line 1156: added "like ". -Line 1165: changed "a" into "an". -Line 1174: added "(and/or partly due to post-Caledonian, Devonian-Mississippian, extensional detachment faulting and folding)". -Lines 1176-1177: changed "Figure 1aFigure

Interactive

comment
Printer-friendly version

Discussion paper

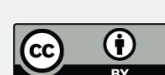


5" into "(Figure 1a and 5)". -Line 1179: added ", 2020". -Line 1187: added reference to the work by Siedlecki and Turnau (1964). The reference was also added to the reference list. -Line 1191: deleted ",". -Line 1198: added ",. -Line 1201: added "in". -Line 1207: changed "suggesting" into "supporting". -Line 1238: changed "Mesoproterozoic" to "Neoproterozoic". -Lines 1238, 1261 and 1270: changed "Pinkiefjellet" to "Pinkie". -Line 1264: changed "is" into "may be". -Line 1279: added "Recently postulated prograde amphibolite-facies metamorphism in the Pinkie Unit may suggest Late Devonian-Mississippian (371-355 Ma) contractional tectonism in rocks of the Pinkie Unit in Prins Karls Forland (Kośmińska et al., 2020). Nevertheless, since these rocks were located at great depth, the Late Devonian-Mississippian ages obtained for prograde amphibolite facies metamorphism have no implications for Late Devonian deformation in shallow-crustal rocks in Dickson Land since deep contractional tectonics are commonly associated with near-surface extension during late-post-orogenic collapse (Platt, 1986; Rey et al., 2001; Teyssier et al., 2005). Late Devonian-Mississippian, (postulated) prograde, amphibolite facies metamorphism in Prins Karls Forland may correlate with late Caledonian eclogite facies metamorphism in deep portions of the crust on the conjugate eastern-northeastern Greenland margin (Gilotti et al., 2004; McClelland et al., 2006; Augland et al., 2010, 2011), which developed synchronously with the deposition of Devonian-Mississippian collapse basins along low-angle extensional detachments at the surface (Stemmerik et al., 1991, 1998, 2000; Larsen and Bengaard, 1991; Strachan, 1994; Larsen et al., 2008)... -Line 1279: added "In Oscar II Land, Ziemniak et al. (2020) recently established that presumed Ellesmerian greenschist facies metamorphism (Barnes et al., 2020) actually initiated at ca. $410 \mathrm{Ma}$ (Early Devonian), was related to a NW-SE-striking mylonitic shear zone, and was coeval with sinistral movements along the WNW-ESE-striking Vimsodden-Kosibapasset Shear Zone in southwestern Spitsbergen (Faehnrich et al., 2020). In northwestern (McCann, 2000) and central-northern Spitsbergen (Koehl et al., in prep.), Early Devonian times were characterized by the deposition of several kilometer-thick sedimentary successions of the Red Bay Group and Wood Bay Formation (Gee and Moody-Stuart,

Printer-friendly version

Discussion paper
Interactive

comment

\section{Discussion paper}

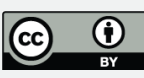


1966; Friend et al., 1966; Friend and Moody-Stuart, 1972; Murascov and Mokin, 1979; Friend et al., 1997) along similarly striking, NNE-dipping normal (-sinistral) faults that actually merge at depth with major WNW- ESE- to NW-SE-striking, potentially Timanian shear zones (Koehl et al., in prep.). Thus, it is more probable that Early Devonian greenschist facies metamorphism and mylonitization in Oscar II Land was related to late-post Caledonian extensional-transtensional tectonic processes and/or to coeval, deep, late Caledonian deformation. Also in Oscar II Land, 40Ar-39Ar geochronology from Michalski et al. (2017) evidenced two episodes of significant thermal overprints at $377-326$ and ca. $300 \mathrm{Ma}$, the latter of which is believed to be related to rifting. If it is possible that the latest of these two events is related to rifting, then it is natural to suggest that the first one too may conceivably be related to extensional tectonic processes (e.g., core complex exhumation and/or extensional detachment faulting).", and Michalski et al. (2017), Ziemniak et al. (2020) and Barnes et al. (2020) to the reference list. -Line 1284: added “, 2020". -Line 1285: added “/extensional collapse”. -Line 1288: changed "contraction" into "deformation" and added "This is further supported by paleomagnetic and 40Ar-39Ar geochronological data from Michalski et al. (2017) that do not support a pre-Caledonian link or proximity between the Pearya terrane and western Spitsbergen, and by a study of detrital zircon in western and central Spitsbergen suggesting affinities with northern Baltica (Gasser and Andresen, 2013), i.e., that westerncentral Spitsbergen was located away from potential Ellesmerian deformation in northern Greenland and Arctic Canada.". -Line 1289: added "and the Early DevonianMississippian ages by Barnes et al. (2020) and Ziemniak et al. (2020) for greenschist facies metamorphism in Oscar II Land". -Lines 1299-1300: changed "Cenozoic contraction" into "Eurekan deformation". -Line 1313: changed "have been deposited" into "be preserved". -Line 1316: changed "Juxtaposition" into "Thrusting", and "against" into "over". -Line 1317: added "a combination of Devonian syn-depositional, extensional, detachment-related folding, ". -Line 1330: added "-tilted". -Lines 1339-1340: rewrote "of the stratigraphic contact" into "(tectonized or non-tectonized) of the unconformity". -Line 1342: added "(along the Triungen-Grønhorgdalen Fault Zone)". -Line

Interactive comment
Printer-friendly version

Discussion paper

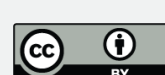


1364: added ", and to Erik Johannessen and Reinhard Feisel for high-resolution field photographs in Dickson Land". -Lines 1369-1370: changed "now digitized and by the author of the present manuscript and soon available from the Norwegian Polar Institute Library; list of digitized publications" into "available at the Norwegian Polar Institute Library in Tromsø, Norway; list of publications". -Line 1373: added "Finally, last but not least, the author thank Dr. Karsten Piepjohn, Assoc. Prof. Jaroslaw Majka and an anonymous referee for their comments and resulting improvements on the manuscript.". -Line 1496: moved reference to Dallmann (1999) to line 1510 and changed it into Dallmann et al. (1999). Added ", Dypvik, H., Gjelberg, J. G., Harland, W. B., Johannessen, E. P., Keilen, H. B., Larssen, G. B., Lønøy, A., Midbøe, P. S., Mørk, A., Nagy, J., Nilsson, I., Nøttvedt, A., Olaussen, S., Pcelina, T. M., Steel, R. J. and Worsley, D." line 1510. -Line 1852: added ".." -Line 1945: changed "Haitana" into "Haitanna". -Line 1958: added "locality". -Line 1967: deleted "Fig. ". -Line 1978: changed "Figure 1b" into "Figure 2". -Line 1984: added "See legend in Figure 2". -Line 1993: added "is shown". -Line 1995: added "see" and "for location". -Line 1995: added "gently east-dipping", "(" and "-tilted?)". -Line 1996: added "dotted ". -Line 1999: added "trace". -Line 2012: added "and top-west Eurekan thrusts within lower Permian rocks". -Line 2025: added "early Cenozoic". -Line 2033: added "latest Devonian-“. -Line 2034: added "latest Mississippian-“. -Line 2096: added " and Eurekan deformation". -Fixed figure reference font and error messages throughout the manuscript and supplements. -Changed reference to Koehl (2019) into Koehl (2020) and added reference to Koehl (2019) throughout the text. -Changed reference to Dallmann (1999) into Dallmann et al. (1999) throughout the manuscript. -Corrected "Famenian" into "Famennian" in three occurrences in the manuscript. -Corrected "Arktikugol" into "Trust Arktikugol" in two occurences in the manuscript. âĂČ References Aakvik, R.: Fasies analyse av Undre Karbonske kullførende sedimenter, Billefjorden, Spitsbergen, Ph.D. Thesis, University of Bergen, Bergen, Norway, 219 pp., 1981. Ahlborn, M. and Stemmerik, L.: Depositional evolution of the Upper Carboniferous - Lower Permian Wordiekammen carbonate platform, Nordfjorden High, central Spitsbergen, Arctic Nor- 
way, Norw. J. Geol., 95, 1, 91-126, 2015 Bahroudi, A. and Koyi, H. A.: Effect of spatial distribution of Hormuz salt on deformation style in the Zagros fold and thrust belt: an analogue modelling approach, J. Geol. Soc. London, 160, 719-733, 2003. Balashov, Yu. A., Larionov, A. N., Gannibal, L. F., Sirotkin, A. N., Tebenkov, A. M., Ryüngenen, G. I. and Ohta, Y.: An Early Proterozoic U-Pb zircon age from an Eskolabreen Formation gneiss in southern Ny Friesland, Spitsbergen, Polar Res., 12:2, 147-152, 1993. Bardossy, G. and Fodor, J.: Traditional and New Ways to Handle Uncertainty in Geology, Nat. Resour. Res., 10, 3, 179-187, 2001. Beauchamp, B., Alonso-Torres, D., Piepjohn, K., Thériault, P. and Grasby, S. E.: Early Carboniferous syn-rift sedimentation in the Sverdrup Basin (Yelverton Pass area, northern Ellesmere Island, Arctic Canada): A solution to the Okse Bay problem, in: Circum-Arctic Structural Events: Tectonic Evolution of the Arctic Margins and Trans-Arctic Links with Adjacent Orogens, edited by: Piepjohn, K., Strauss, J. V., Reinhardt, L. and McClelland, W. C., GSA Spec. Paper, 541, 255-284, 2018. Beaudoin, A., Augier, R., Laurent, V., Jolivet, L., Lahfid, A., Bosse, V., Arbaret, L., Rabillard, A. and Menant, A.: The Ikaria high-temperature Metamorphic Core Complex (Cyclades, Greece): Geometry, kinematics and thermal structure, Journal of Geodynamics, 92, 18-41, 2015. Bergh S. G., Braathen, A. and Andresen, A.: Interaction of Basement-Involved and Thin-Skinned Tectonism in the Tertiary Fold-Thrust Belt of Central Spitsbergen, Svalbard, AAPG Bulletin, 81, 637661, 1997. Bergh, S. G., Maher Jr., H. D. and Braathen, A.: Tertiary divergent thrust directions from partitioned transpression, Brøggerhalvøya, Spitsbergen, Norsk Geol. Tidsskr., 80, 63-82, 2000. Bergh, S. G., Maher Jr., H. D. and Braathen, A.: Late Devonian transpressional tectonics in Spitsbergen, Svalbard, and implications for basement uplift of the Sørkapp-Hornsund High, J. Geol. Soc. London, 168, 441-456, 2011. Bergh, S. G., Sylvester, A. G., Damte, A. and Indrevær, K.: Polyphase kinematic history of transpression along the Mecca Hills segment of the San Andreas fault, southern California, Geosphere, 16, 3, 901-934, 2019. Berry, C. M. and Marshall, J. E. A.: Lycopsid forests in the early Late Devonian paleoequatorial zone of Svalbard, Geology, 43, 1043-1046, 2015. Birkenmajer, K.: Devonian, Carboniferous and Permian for- 
mations of Hornsund, Vestspitsbergen, Studia Geologica Polonica, 11, 47-123, 1964. Birkenmayer, K. and Turnau, E.: Lower Carboniferous age of the so-called Wijde Bay Series in Hornsund, Vestspitsbergen, Nor. Polarinst. Årb. 1961, 41-61, 1962. Blinova, M., Faleide, J. I., Gabrielsen, R. H. and Mjelde, R.: Seafloor expression and shallow structure of a fold-and-thrust system, Isfjorden, west Spitsbergen, Polar Res., 31, 11209, 2012. Blinova, M., Faleide, J. I., Gabrielsen, R. H. and Mjelde, R.: Analysis of structural trends of sub-sea-floor strata in the Isfjorden area of the West Spitsbergen Fold-and-Thrust Belt based on multichannel seismic data, J. Geol. Soc. London, 170, 657-668, 2013. Boyer, S. E. and Elliott, D.: Thrust Systems, AAPG Bulletin, 66, 9, 1196-1230, 1982. Braathen, A., Bergh, S. G. and Maher Jr., H. D.: Application of a critical wedge taper model to the Tertiary transpressional fold-thrust belt on Spitsbergen, Svalbard, GSA Bull., 111, 10, 1468-1485, 1999a. Braathen, A., Bergh, S. G., Karlsen, F., Maher Jr., H. D., Andresen, A., Hansen, A.-I. and Bergvik, A.: Kinematics of the isfjorden-Ymerbukta Fault Zone: a dextral oblique-thrust ramp in the Tertiary fold-thrust belt of Spitsbergen, Norw. J. Geol., 79, 227-240, 1999b. Braathen, A., Nordgulen, $\varnothing$., Osmundsen, P. T., Andersen, T. B., Solli, A. and Roberts, D.: Devonian, orogeny-parallel, opposed extension in the Central Norwegian Caledonides, Geology, 28, 7, 615-618, 2000. Braathen, A., Bælum, K., Maher Jr., H. D. and Buckley, S. J.: Growth of extensional faults and folds during deposition of an evaporite-dominated halfgraben basin; the Carboniferous Billefjorden Trough, Svalbard, Norsk Geol. Tidsskr., 91, 137-160, 2011. Braathen, A., Osmundsen, P. T., Maher Jr., H. D. and Ganerød, M.: The Keisarhjelmen detachment records Silurian-Devonian extensional collapse in Northern Svalbard, Terra Nova, 30, 34-39, 2018a. Braathen, A., Osmundsen, P. T., Maher, H. and Ganerød, M.: Reply to Comment on "The Keisarhjelmen detachment records Silurian-Devonian extensional collapse in Northern Svalbard", Terra Nova, 30, 322-324, 2018b. Braathen, A., Ganerød, M., Maher Jr., H., Myhre, P. I., Osmundsen, P. T., Redfield, T. and Serck, C.: Devonian extensional tectonicsin Svalbard; Raudfjorden's synclinal basin above the Keisarhjelmen detachment, 34th Nordic Geological Winter Meeting, January 8th-10th 2020, Oslo, Norway, 2020. Brinkmann, L.: Geologie 
des östlichen zentralen Dickson Landes und Palynologie der Mimerdalen Formation (Devon), Spitzbergen (Geology of eastern-central Dickson Land and palynology of the Mimerdalen Formation [Devonian], Spitsbergen), unpublished Master's Thesis, University of Münster, Münster, Germany, 94 pp., 1997. Bugge, T., Mangerud, G., Elvebakk, G., Mørk, A., Nilsson, I., Fanavoll, S. and Vigran, J. O.: The Upper Palaeozoic succession on the Finnmark Platform, Barents Sea, Norsk Geol. Tidsskr., 75, 3-30, 1995. Buggisch, W., Piepjohn, K., Thiedig, F. and von Gosen, W.: A Middle Carboniferous Conodont Fauna from Blomstrandhalvøya (NW-Spitsbergen): Implications on the Age of Post-Devonian Karstification and the Svalbardian Deformation, Polarforschung, 62, 2/3, 83-90, 1994. Chauvet, A. and Séranne, M.: Extension-parallel folding in he Scandinavian Caledonides: implications for late-orogenic processes, Tectonophys., 238, 31-54, 1994. Chorowicz, J.: Gravity-induced detachment of Devonian basin sediments in northern Svalbard, Norsk Geol. Tidsskr., 72, 21-25 1992. Clayton, G., Coquel, R., Doubinger, J., Gueinn, K. J., Loboziak, S., Owens, B. and Streel, M.: Carboniferous Miospores of Western Europe: illustration and zonation, Meded. Rijks Geol. Dienst, 29, 1-71, 1977. Costa, E. and Vendeville, B. C.: Experimental insights on the geometry and kinematics of fold-and-thrust belts above weak, viscous evaporitic décollement, Journal of Structural Geology, 24, 1729-1739, 2002. Cutbill, J. L. and Challinor, A.: Revision of the Stratigraphical Scheme for the Carboniferous and Permian of Spitsbergen and Bjørnøya, Geol. Mag., 102, 418-439, 1965. Cutbill, J. L., Henderson, W. G. and Wright, N. J. R.: The Billefjorden Group (Early Carboniferous) of central Spitsbergen, Norsk Polarinst. Skr., 164, 57-89, 1976. Dallmann, W. K.: Multiphase tectonic evolution of the Sørkapp-Hornsund mobile zone (Devonian, Carboniferous, Tertiary), Svalbard, Norsk Geol. Tidsskr., 72, 49-66, 1992. Dallmann, W. K.: Geoscience Atlas of Svalbard, Norsk Polarinstitutt, Tromsø, Norway, Rapportserie nr. 148, 2015. Dallmann, W. K. and Piepjohn, K.: Comment on "The Keisarhjelmen detachment records Silurian-Devonian extensional collapse in Northern Svalbard", Terra Nova, 30, 319321, 2018. Dallmann, W. K. and Piepjohn, K.: The structure of the Old Red Sandstone and the Svalbardian Orogenic Event (Ellesmerian Orogeny) in Svalbard, Norg. Geol. 
Unders. B., submitted. Dallmann, W. K., Dypvik, H., Gjelberg, J. G., Harland, W. B., Johannessen, E. P., Keilen, H. B., Larssen, G. B., Lønøy, A., Midbøe, P. S., Mørk, A., Nagy, J., Nilsson, I., Nøttvedt, A., Olaussen, S., Pcelina, T. M., Steel, R. J. and Worsley, D.: Lithostratigraphic Lexicon of Svalbard, edited by: Dallmann, W. K., Norwegian Polar Institute, Polar Environmental Centre, Tromsø, Norway, 1999. Dallmann, W. K., Piepjohn, K. and Blomeier, D.: Geological map of Billefjorden, Central Spitsbergen, Svalbard, with geological excursion guide, Scale $1: 50,000$, Temakart No. 36, Norsk Polarinstitutt, 2004. Dissmann, B. and Grewing, A.: Post-svalbardische kompressive Strukturen im westlichen Dickson Land (Hugindalen), Zentral-Spitzbergen, Münster. Forsch. Geol. Paläont., 82, 235-242, 1997. Eide, E. A., Torsvik, T. H., Andersen, T. B. and Arnaud, N. O.: Early Carboniferous Unroofing in Western Norway: A Tale of Alkali Feldspar Thermochronology, The Journal of Geology, 107, 353-374, 1999. Eide, J. R., Ree, R. and Rockman, P. O.: Final well report - 7816/12-1 July 1991, Norsk Hydro A.S., Harstad, Norway, 1991. Evdokimov, A. N., Burnaeva, M. Yu., Radina, E. S. and Sirotkin, A. N.: The First Find of Kimberlitic Accessory Minerals in Mafic-Ultramafic Dikes in Spitsbergen, Doklady Earth Sciences, 407, 2, 275-279, 2006. Faehnrich, K., Schneider, D., Manecki, M., Czerny, J., Myhre, P. I., Majka, J., Kośmińska, K., Barnes, C. and Maraszewska, M.: eureka deformation on Prins Karls Forland, Svalbard - new insights from Ar40/Ar39 muscovite dating, Geophys. Res. Abstracts, 19, EGU General Assembly 2017, 23-28 April, Vienna, Austria, 2017. Fard, I. A., Braathen, A., Mokhtari, M. and Alavi, S. A.: Interaction of the Zagros Fold-Thrust Belt and the Arabian-type, deep-seated folds in the Abadan Plain and the Dezful Embayment, SW Iran, Petroleum Geoscience, 12, 347-362, 2006. Fletcher, J. M. and Bartley, J. M.: Constrictional strain in a non-coaxial shear zone: implications for folds and rock fabrics development, central Mojave metamorphic core complex, California, Journal of Structural Geology, 16, 4, 555-570, 1994. Flood, B., Gee, D. G., Hjelle, A., Siggerud, T. and Winsnes, T. S.: The geology of Nordaustlandet, northern and central parts, Norsk Polarinst. Skr., 146, 145 pp., 1969. Fossen, H.: Writing papers with an emphasis on structural geology and tectonics: advices and warnings, Braz. J. Geol., 49, 4, 1-6, 
2020. Fossen, H., Teyssier, C. and Whitney, D. L.: Transtensional folding, Journal of Structural Geology, 56, 89-102, 2013. Frebold, H.: Geologie von Spitzbergen, der Bäreninsel, des König Karl- und Franz Joseph-Landes, Geologie der Erde, 7, Bornträger, Berlin, 195 pp., 1935 Friend, P. F., Harland, W. B., Rogers, D. A., Snape, I. and Thornley, R. S.: Late Silurian and Early Devonian stratigraphy and probable strike-slip tectonics in northwestern Spitsbergen, Geol. Mag., 134, 4, 459-479, 1997. Gayer, R. A., Gee, D. G., Harland, W. B., Miller, J. A., Spall, H. R., Wallis, R. H. and Winsnes, T. S.: Radiometric age determinations on rocks from Spitsbergen, Norsk Polarinstitutt Skrifter, 137, 43 pp., 1966. Gee, D. G. and Page, L. M.: Caledonian terrane assembly on Svalbard: New evidence from 40Ar/39Ar dating in Ny Friesland, American Journal of Science, 294, 1166-1186, 1994. Gilotti, J. A., Nutman, A. P. and Brueckner, H. K.: Devonian to Carboniferous collision in the Greenland Caledonides: U-Pb zircon and $\mathrm{Sm}-\mathrm{Nd}$ ages of high-pressure and ultrahigh-pressure metamorphism, Contrib. Mineral Petrol., 148, 216-235, 2004. Gjelberg, J. G.: Upper Devonian (Famennian) - Middle Carboniferous succession of Bjørnøya, a study of ancient alluvial and coastal marine sedimentation, Norsk Polarinst. Skr., 174, 67 pp., 1981. Gjelberg, J. G.: Early-Middle Carboniferous sedimentation on Svalbard. A study of ancient alluvial and coastal marine sedimentation in rift- and strike-slip basins, Ph.D. Thesis, University of Bergen, Bergen, Norway, 306 pp., 1984. Gjelberg, J. G. and Steel, R. J.: An outline of LowerMiddle Carboniferous sedimentation on Svalbard: Effects of tectonic, climatic and sea level changes in rift basin sequences, in: Geology of the North Atlantic Borderlands, edited by: Kerr, J.W. and Ferguson, A. J., Can. Soc. Of Petrol. Geol. Mem., 7, 543-561, 1981. Grantz, A. and May, S. D.: Summary Geologic Report for Barrow Arch Outer Continental Shelf (OCS) Planning Area, Chukchi Sea, Alaska, United States Department of the Interior, Geological Survey, 84-395, 1984. Hallett, B. W., McClelland, W. C. and Gilotti, J. A.: The Timing of Strike-Slip Deformation Along the Storstrømmen Shear Zone, Greenland Caledonides: U-Pb Zircon and Titanite Geochronology, Geoscience Canada, 41, 19-45, 2014. Harland, W. B. and Horsfield, W. T.: West Spitsbergen Orogen, in: Mesozoic-Cenozoic orogenic belts, edited by: Spencer, A. 
M., Geol. Soc. London Spec. Publ., 4, 747-755, 1974. Harland, W. B. and Wright, N. J. R.: Alternative hypothesis for the pre-Carboniferous evolution of Svalbard, Norsk Polarinst. Skr., 167, 89-117, 1979. Harland, W. B., Cutbill, L. J., Friend, P. F., Gobbett, D. J., Holliday, D. W., Maton, P. I., Parker, J. R. and Wallis, R. H.: The Billefjorden Fault Zone, Spitsbergen - the long history of a major tectonic lineament, Norsk Polarinst. Skr., 161, 1-72, 1974. Harland, W. B., Mann, A. and Townsend, C.: Deformation of anhydrite-gypsum rocks in central Spitsbergen, Geol. Mag., 125, 103-116, 1988. Harland, W. B., Scott, R. A., Auckland, K. A. and Snape, I.: The Ny Friesland Orogen, Spitsbergen, Geol. Mag., 129, 6, 679-708, 1992. Hughes, N. F. and Playford, G.: Palynological reconnaissance of the Lower Carboniferous of Spitsbergen, Micropaleontology, 7, 1, 27-44, 1961. Janecke, S. U., Markowski, D. K., Evans, J. P., Persaud, P. and Jenney, M.: Durmid ladder structure and its implications for the nucleation sites of the next $M>7.5$ earthquake on the San Andreas fault or Brawley seismic zone in southern California, Lithosphere, 10, 5, 602-631, 2018. Johansson, A. and Gee, D. G.: The late Palaeoproterozoic Eskolabreen granitoids of southern Ny Friesland, Svalbard Caledonides - geochemistry, age, and origin, GFF, 121:2, 113-126, 1999. Kempe, M., Niehoff, U., Piepjohn, K. and Thiedig, F.: Kaledonische und svalbardische Entwicklung im Grundgebirge aud der Blomstrandhalvøya, NW-Spitzbergen, Münster. Forsch. Geol. Paläont., 82, 121-128, 1997. Ketner, K. B.: An Alternative Hypothesis for the Mid-Paleozoic Antler Orogeny in Nevada, USGS Professional Paper, 1790, 11 pp., 2012. Klitzke, P., Franke, D., Ehrhardt, A., Lutz, R., Reinhardt, L., Heyde, I. and Faleide, J. I.: The Palaeozoic Evolution of the Olga Basin Region, Northern Barents Sea: A Link to the Timanian Orogeny, Geochem., Geophy., Geosy., 20, 614-629, 2019. Koehl, J.-B. P.: Impact of Timanian thrusts on the Phanerozoic tectonic history of Svalbard, Friday Seminar, 13th September 2019, University of Tromsø, Tromsø, Norway, 2019a. Koehl, J.-B. P.: Impact of Timanian thrusts on the Phanerozoic tectonic history of Svalbard, ARCEx Conference, October 21st-24th 2019, Sommarøya, Norway, 2019b. Koehl, J.-B. P.: Impact of Timanian thrusts on the Phanerozoic tectonic history of Svalbard, Keynote presentation EGU General Assembly, May 3rd-8th 2020,

Printer-friendly version

Discussion paper
Interactive comment 
Vienna, Austria, 2020. Koehl, J.-B. P. and Muñoz-Barrera, J. M.: From widespread Mississippian to localized Pennsylvanian extension in central Spitsbergen, Svalbard,

Solid Earth, 9, 1535-1558, 2018. Koehl, J.-B. P., Bergh, S. G., Henningsen, T. and Faleide, J. I.: Middle to Late Devonian-Carboniferous collapse basins on the Finnmark Platform and in the southwesternmost Nordkapp basin, SW Barents Sea, Solid Earth, 9, 341-372, 2018. Koehl, J.-B. P., Collombin, M., Taule, C., Christophersen, G. and Allaart, L.: Influence of WNW-ESE-striking faults on Devonian-Permian sedimentary rocks in Billefjorden and implications for Ellesmerian and Eurekan tectonic events, Solid Earth, in prep. a. Koehl, J.-B. P., Klitzke, P., Schweitzer, J., Dichiarante, A. M. and Anell, I.: Timanian thrust systems in the Svalbard Archipelago, Solid Earth, in prep. b. Kośmińska, K., Spear, F. and Majka, J.: P-T-t metamorphic evolution of highly deformed metapelites from the Pinkie unit of western Svalbard using quartz-in-garnet barometry, trace element thermometry, P-T-X-M diagrams and monazite in-situ dating, Geophys. Res. Abstracts, 19, EGU General Assembly, Vienna, Austria, 8-13th April, 2017. Kosminska, K., Spear, F. S., Majka, J., Faehnrich, K., Manecki, M., Piepjohn, K. and Dallmann, W. K.: Deciphering late Devonian-early Carboniferous P-T-t path of mylonitized garnet-mica schists from Prins Karls Forland, Svalbard, J. Metamorph., Geol., 00, 1-23, 2020. Krabbendam, M. and Dewey, J. F.: Exhumation of UHP rocks by transtension in the Western Gneiss Region, Scandinavian Caledonides, in: Continental Transpressional and Transtensional Tectonics, edited by: Holdsworth, R. E., Strachan, R. A. and Dewey, J. F., Geol. Soc. London, Spec. Publi., 135, 159-181, 1998. Kumar, N., Granath, J. W., Emmet, P. A., Helwig, J. A. and Dinkelman, M. G.: Stratigraphic and Tectonic Framework of the US Chukchi Shelf: Exploration Insights from a New Regional Deep-seismic Reflection Survey, in: Arctic Petroleum Geology, edited by, Spencer, A. M., Gautier, D., Stoupakova, A., Embry, A. F. and Sørensen, K., Geol. Soc. London Memoirs, 35, 1, 501-508, 2011. Labrousse, L., Elvevold, S., Lepvrier, C. and Agard, P.: Structural analysis of high-pressure metamorphic rocks of Svalbard: Reconstructing the early stages of the Caledonian orogeny, Tectonics, 27, 22 pp., 2008. Lamar, D. L. and Douglass, D. N.: Geology of an area astride the 
Billefjorden Fault Zone, Northern Dicksonland, Spitsbergen, Svalbard, Polarist. Skr., 197, 46 pp., 1995. Lamar, D. L., Reed, W. E. and Douglass, D. N.: Structures bearing on the sense and magnitude of displacement and tectonic significance of Billefjorden Fault Zone, Dicksonland, Spitsbergen, Svalbard: Progress report, 1982 field season, Lamar-Merifield, Geologists, Technical report 82-6, 48 pp., 1982. Lamar, D. L., Reed, W. E. and Douglass, D. N.: Billefjorden fault zone, Spitsbergen: Is it part of a major Late Devonian transform?, GSA, 97, 1083-1088, 1986. Lane, L. S.: DevonianCarboniferous paleogeography and orogenesis, northern Yukon and adjacent Arctic Alaska, Can. J. Earth Sci., 44, 679-694, 2007. Larsen, P.-H. and Bengaard, H.-J.: Devonian basin initiation in East Greenland: a result of sinistral wrench faulting and Caledonian extensional collapse, J. Geol. Soc. London, 148, 355-368, 1991. Larsen, P.-H., Olsen, H. and Clack, J. A.: The Devonian basin in East Greenland-Review of basin evolution and vertebrate assemblages, GSA Bull. Mem., 202, 273-292, 2008. Larssen, G. B., Elvebakk, G., Henriksen, S. E., Nilsson, I., Samuelsberg, T. J., Svånå, T. A., Stemmerik, L. and Worsley, D.: Upper Palaeozoic lithostratigraphy of the Southern Norwegian Barents Sea, Norwegian Petroleum Directorate Bulletin, 9, 1-76, 2002. Leever, K. A., Gabrielsen, R. H., Sokoutis, D. and Willingshofer, E.: The effect of convergence angle on the kinematic evoluton of strain partitioning in transpressional brittle wedges: Insight from analog modeling and high-resolution digital image analysis, Tectonics, 30, 1-25, 2011a. Leever, K. A., Gabrielsen, R. H., Faleide, J. I. and Braathen, A.: A transpressional origin for the West Spitsbergen fold-and-thrust belt: Insight from analog modelling, Tectonics, 30, 24 pp., 2011b. Lindemann, F.-J., Volohonsky, E. and Marshall, J. E.: A bonebed in the Hørbybreen Formation (Fammenian-Viséan) on Spitsbergen, NGF Abstracts and Proceedings, 1, Winter Meeting, Oslo, 8-10th January, 2013. Lister, G. S. and Davis, G. A.: The origin of metamorphic core complexes and detachment faults formed during Tertiary continental extension in the northern Colorado River region, U.S.A., Journal of Structural Geology, 11, 1/2, 65-94, 1989. Livshitz, Ju. Ja.: New data on the geological structure of the Pyramiden area (Vestspitsbergen), Uchenie Zapiski (Inst. Geol. Arctic) Regional'naya geologiya (NIIGA), 
9, 36-56, 1966. Lopes, G., Mangerud, G. and Clayton, G.: The palynostratigraphy of the Mississippian Birger Johnsonfjellet section, Spitsbergen, Svalbard, Palynology, 43:4, 631-649, 2018a. Lopes, G., McLean, D., Mangerud, G. and Clayton, G.: A new Mississippian biozonal scheme for the Finnmark Platform, Norway - Palynostratigraphic integration of exploration wells 7128/4-1 and 7128/6-1, Mar Petrol. Geol., 92, 94-108, 2018b. Lorenz, H., Männik, P., Gee, D. and Proskurnin, V.: Geology of the Svernaya Zemlya Archipelago and the North Kara Terrane in the Russian high Arctic, Int. J. Earth Sci., 97, 519-547, 2008. Lyberis, N. and Manby, G.: The West Spitsbergen Fold Belt: the result of Late Cretaceous-Palaeocene Greenland-Svalbard Convergence?, Geol. J., 28, 125-136, 1993. Maher Jr., H. D., Bergh, S. G., Braathen, A. and Ohta, Y.: Svartfjella, Eidembukta, and Daudmannsodden lineament: Tertiary orogenparallel motion in the crystalline hinterland of Spitsbergen's fold-thrust belt, Tectonics, 16, 1, 88-106, 1997. Majka, J. and Kośmińska, K.: Magmatic and metamorphic events recorded within the Southwestern basement province of Svalbard, Arktos, 3:5, 2017. Majka, J., Mazur, S., Manecki, M., Czerny, J. and Holm, D. K.: Late Neoproterozoic amphibolite-facies metamorphism of a pre-Caledonian basement block in southwest Wedel Jarlsberg Land, Spitsbergen: new evidence from U-Th-Pb dating of monazite, Geol. Mag., 145, 6, 822-830, 2008. Majka, J., Czerny, J., Mazur, S., Holm, D. K. and Manecki, M.: Neoproterozoic metamorphic evolution of the Isbjørnhamna Group rocks from south-western Svalbard, Polar Res., 29, 250-264, 2010. Manby, G. M. and Lyberis, N.: Contrasting tectono-metamorphic terranes in NE Svalbard: Sm/Nd, Rb/Sr, isotopic and structural constraints, Terranes in the Arctic Caledonides, Terra Abstr., 4, 22-23, 1991. Manby, G. M. and Lyberis, N.: Tectonic evolution of the Devonian Basin of northern Spitsbergen, Norsk Geol. Tidsskr., 72, 7-19, 1992. Marshall, J., Lindemann, F. J., Finney, S. and Berry, C.: A Mid Fammenian (Late Devonian) spore assemblage from Svalbard and its significance, CIMP Meeting, Bergen, Norway, 17-18th September, 2015. Mazur, S., Czerny, J., Majka, J., Manecki, M., Holm, D., Smyrak, A. and Wypych, A.: A strike-slip terrane boundary in Wedel Jarlsberg Land, Svalbard, and its bearing on correlations pf SW Spitsbergen with the Pearya terrane and Timanide 
belt, J. Geol. Soc. London, 166, 529-544, 2009. McCann, A. J.: The Billefjorden Fault Zone, Dickson Land, Svalbard: Basement fault control on cover deformation, Ph.D. Thesis, Imperial College, London, UK, 1993. McCann, A. J.: Deformation of the Old Red Sandstone of NW Spitsbergen; links to the Ellesmerian and Caledonian orogenies, in: New Perspectives on the Old Red Sandstone, edited by: Friends, P. F. and Williams, B. P. J., Geol. Soc. London, 180, 567-584, 2000. McCann, A. J. and Dallmann, W. K.: Reactivation of the long-lived Billefjorden Fault Zone in north central Spitsbergen, Svalbard, Geol. Mag., 133, 63-84, 1996. McClay, K. R. and Insley, M. W.: Duplex structures in the Lewis thrust sheet, Crowsnest Pass, Rocky Mountains, Alberta, Canada, Journal of Structural Geology, 8, 8, 911-922, 1986. McClelland, W. C., Power, S. E., Gilotti, J. A., Mazdab, F. K. and Wopenka, B.: U-Pb SHRIMP geochronology and trace-element geochemistry of coesite-bearing zircons, North-East Greenland Caledonides, GSA, Spec. Paper, 403, 23-43, 2006. McClelland, W. C., Gilotti, J. A., Ramarao, T., Stemmerik, L. and Dalhoff, F.: Carboniferous basin in Holm Land records local exhumation of the North-East Greenland Caledonides: Implications for the detrital zircon signature of a collisional orogeny, Geosphere, 12, 925-947, 2016. Michaelsen, B.: Strukturgeologie des svalbardischen Ûberschiebungs- und Faltengürtels im zentralen, östlichen Dickson Land, Spitzbergen, Master's Thesis, University of Münster, Münster, Germany, 169 pp., 1998. Michaelsen, B., Piepjohn, K. and Brinkmann, L.: Struktur und Entwicklung der svalbardischen Mimerelva Synkline im zentralen Dickson Land, Spitzbergen, 82, 203-214, 1997. Michalski, K.: Palaeomagnetism of metacarbonates and fracture fills of Kongsfjorden islands (western Spitsbergen): Towards a better understanding of late- to post-Caledonian tectonic rotations, Polish Polar Res., 39, 1, 51-75, 2018. Michalski, K., Manby, G., Nejbert, K., Domanska-Siuda, J. and Burzynski, M.: Using palaeomagnetism and isotopic data to investigate late to postCaledonian tectonothermal processes within the Western Terrane of Svalbard, J. Geol. Soc., London, 174, 572-590, 2017. Mora, A., Parra, M., Strecker, M. R., Kammer, A., Dimaté, C. and Rodriguez, F.: Cenozoic contractional reactivation of Mesozoic extensional structures in the Eastern Cordillera of Colombia, Tectonics, 25, 1-19, 2006.

Interactive comment
Printer-friendly version

Discussion paper 
Newman, M. J., Burrow, C. J. and den Blaauwen, J. L.: The Givetian vertebrate fauna from the Fiskekløfta Member (Mimerdalen Subgroup), Svalbard. Part I. Stratigraphic and faunal review. Part II. Acanthodii, Norw. J. Geol., 99, 1-16, 2019. Norton, M. G.: The Nordfjord-Sogn Detachment, W. Norway, Norw. J. Geol., 67, 93-106, 1987. Olovyanishnikov, V. G., Roberts, D. and Siedlecka, A.: Tectonics and Sedimentation of the Meso- to Neoproterozoic Timan-Varanger Belt along the Northeastern Margin of Baltica, Polarforschung, 68, 267-274, 2000. Omodei, E., De Domenico, M. and Arenas, A.: Evaluating the impact of interdisciplinary research: a multilayer network approach, 5, 2, 2035-246, 2016. Osmundsen, P. T. and Andersen, T. B.: Caledonian compressional and late-orogenic extensional deformation in the Staveneset area, Sunnfjord, Western Norway, Journal of Structural Geology, 16, 10, 1385-1401, 1994. Osmundsen, P. T., Andersen, T. B., Markussen, S. and Svendby, A. K.: Tectonics and sedimentation in the hangingwall of a major extensional detachment: the Devonian Kvamshesten basin, western Norway, Basin Res., 10, 213-234, 1998. Osmundsen, P. T., Braathen, A., Sommaruga, A., Skilbrei, J. R., Nordgulen, Ø., Roberts, D., Andersen, T. B., Olesen, O. and Mosar, J.: Metamorphic core complexes and gneiss-cored culminations along the Mid-Norwegian margin: and overview and some current ideas, in: Onshore-Offshore Relationships on the North Atlantic Margin, edited by: Wandås, B. T. G., Nystuen, J. P., Eide, E. and Gradstein, F., Norw. Petrol. Soc. Spec. Publ., 12, 29-41, 2005. Panieri, G., Bünz, S., Fornari, D. J., Escartin, J., Serov, P., Jansson, P., Torres, M. E., Johnson, J. E., Hong, W., Sauer, S., Garcia, R. and Gracias, $\mathrm{N}$.: An integrated view of the methane system in the pockmarks at Vestnesa Ridge, 79N, Mar. Geol., 390, 282-300, 2018. Phillips, T., Jackson, C. A-L., Bell, R. E., Duffy, O. B. and Fossen, H.: Reactivation of intrabasement structures during rifting: A case study from offshore southern Norway, Journal of Structural Geology, 91, 54-73, 2016. Phillips, T. B., Magee, C., Jackson, C. A.-L. and Bell, R. E.: Determining the three-dimensional geometry of a dike swarm and its impact on later rift geometry using seismic reflection data, Geology, 46, 2, 119-122, 2018. Piepjohn, K.: Tektonische Evolution des Devon-gräben (Old Red) in NW-Svalbard, Ph.D. Thesis, University of 
Münster, Münster, Germany, 170 pp., 1994. Piepjohn, K.: ûberblick über die ArktisExpeditionen der Spitzbergen-Arbeitsgruppe von Prof. Dr. F. Thiedig, GeologischPaläontologisches Institut der Universität Münster, Münster Forsch. Geol. Paläont., 82, 1-14, 1997a. Piepjohn, K.: Erläuterungen zur Geologischen Karte 1:150.000 des Woodfjorden-Gebietes (Haakon VII Land, Andrée Land), NW-Spitzbergen, Svalbard, Münster Forsch. Geol. Paläont., 82, 15-37, 1997b. Piepjohn, K.: The SvalbardianEllesmerian deformation of the Old Red Sandstone and the pre-Devonian basement in NW Spitsbergen (Svalbard), in: New Perspectives on the Old Red Sandstone, edited by: Friend, P. F. and Williams, B. P. J., Geol. Soc. London Spec. Publi., 180, 585-601, 2000. Piepjohn, K., and Dallmann, W. K.: Stratigraphy of the uppermost Old Red Sandstone of Svalbard (Mimerdalen Subgroup), Polar Res., 33:1, 19998, 2014. Piepjohn, K. and Thiedig, F.: Geologisch-tektonische Evolution NW-Spitzbergens im Paläozoikum, Münster Forsch. Geol. Paläont., 82, 215-233, 1997a. Piepjohn, K. and Thiedig, F.: Erläuterungen zur Geologischen Karte 1:50.000 der Germaniahalvøya, Haakon VII Land, Spitzbergen (Svalbard), Münster Forsch. Geol. Paläont., 82, 39-52, 1997b. Piepjohn, K., Brinkmann, L., Di $\beta$ mann, B., Grewing, A., Michaelsen, B. and Kerp, H.: Geologische und strukturelle Entwicklung des Devon sim zentralen Dickson Land, Spitzbergen, Münster. Forsch. Geol. Paläont., 82, 175-202, 1997a. Piepjohn, K., Greving, S., Peletz, G., Thielemann, T., Werner, S. and Thiedig, F.: Kaledonische und svalbardische Entwicklung im kristallinen Basement auf der Mitrahalvøya, Albert I Land, NW-Spitzbergen, Münster. Forsch. Geol. Paläont., 82, 53-72, 1997b. Piepjohn, K., Brinkmann, L., Grewing, A. and Kerp, H.: New data on the age of the uppermost ORS and the lowermost post-ORS strata in Dickson Land (Spitsbergen) and implications for the age of the Svalbardian deformation, in: New Perspectives on the Old Red Sandstone, edited by: Friend, P. F. and Williams, B. P. J., Geol. Soc. London Spec. Publi., 180, 603-609, 2000. Piepjohn, K., von Gosen, W. and Tessensohn, F.: The Eurekan deformation in the Arctic: an outline, J. Geol. Soc., London, 173, 1007-1024, 2016. Pirli, M., Schweitzer, J. and Paulsen, B.: The Storfjorden, Svalbard, 2008-2012 aftershock sequence: Seismotectonics in a polar environment, Tectonophys., 601, 192- 
205, 2013. Platt, J. P.: Dynamics of orogenic wedges and the uplift of high-pressure metamorphic rocks, GSA Bull., 97, 1037-1053, 1986. Playford, G.: Lower Carboniferous microfloras of Spitsbergen, Part 1, Paleontology, 5, 3, 550-618, 1962. Playford, G.: Lower Carboniferous microfloras of Spitsbergen, Part 2, Paleontology, 5, 4, 619678, 1963. Rey, P., Vanderhaeghe, O. and Teyssier, C.: Gravitational collapse of the continental crust: definition, regimes and modes, Tectonophys, 342, 435-449, 2001. Ringset, N. and Andresen, A.: The Gipshuken Fault System - Evidence for Tertiary thrusting along the Billefjorden Fault Zone, in: Tertiary Tectonics of Svalbard, edited by: Dallmann, W. K., Ohta, Y. and Andresen, A., Norsk Polarinstitutt Rapportserie, 46, 6770, 1988. Rippington, S. J., Scott, R. A., Smyth, H., Bogolepova, O. K. and Gubanov, A. P.: The Ellesmerian Orogeny: Fact of Fiction?, GeoCanada 2010, Working with the Earth, 10-14 May, Calgary, Alberta, Canada, 2010. Roberts, D.: Devonian Tectonic Deformation in the Norwegian Caledonides and Its Regional Perspectives, Norg. Geol. Unders., 380, 85-96 1983. Rojo, L. A. and Escalona, A.: Controls on minibasin infill in the Nordkapp Basin: Evidence of complex Triassic synsedimentary deposition influenced by salt tectonics, AAPG Bull., 102, 7, 1239-1272, 2018. Roper, A. and Brookes, M.: Theory and reality of interdisciplinary research, Int. J. Cotemp. Hosp. Manag., 11, 4, 174-179, 1999. Roy, J.-C., L. G.: La géologie du fossé des Vieux Grès Rouges du Spitzberg (archipel du Svalbard, territoire de l'Arctique) - Synthèse stratigraphique, consequences paléoenvironnementales et tectoniques synsédimentaires, Mémoires des sciences de la Terre de l'Université Pierre et Marie Curie, Ph.D. Thesis, Pierre and Marie Curie University, Paris, France, 2007-15, 242 pp., 2007. Roy, J.-C.: La saga des vieux grès rouges du Spitzberg (archipel du Svalbard, Arctique): Une histoire géologique et naturelle, Charenton-le-pont: Auto-Edition Roy-Poulain, 290 pp., 2009. Roy, J.-C., Chorowicz, J., Deffontaines, B., Lepvrier, C. and Tardy, M.: Clues of gravity sliding tectonics at the Eifelian-Givetian boundary in the Old Red Sandstone of the [late Silurian?]-Devonian trough of Andrée Land (Spitsbergen), in: La saga des vieux grès rouges du Spitzberg (archipel du Svalbard, Arctique): Une histoire géologique et naturelle, edited by: Charenton-le-pont: Auto-Edition Roy-Poulain, Norw. J. Geol., 
unpublished. Sandberg, C. A., Morrow, J. R. and Ziegler, W.: Late Devonian sea-level changes, catastrophic events, and mass extinctions, GSA Spec. Paper, 356, 473-487, 2002. Sartini-Rideout, C., Gilotti, J. A. and McClelland, W. C.: Geology and timing of dextral strike-slip shear zones in Danmarkshavnm North-East Greenland Caledonides, Geol. Mag., 143, 4, 431-446, 2006. Scheibner, C., Hartkopf-Fröder, C., Blomeier, D. and Forke, H.: The Mississippian (Lower Carboniferous) in northeast Spitsbergen (Svalbard) and a re-evaluation of the Billefjorden Group, Z. Dt. Ges. Geowiss., 163/3, 293-308, 2012. Schneider, D. A., Faehnrich, K., Majka, J. and Manecki, M.: 40Ar/39Ar geochronologic evidence of Eurekan deformation within the West Spitsbergen Fold and Thrust Belt, in: Circum-Arctic Structural Events: Tectonic Evolution of the Arctic Margins and Trans-Arctic Links with Adjacent Orogens, edited by: Piepjohn, K., Strauss, J. V., Reinhardt, L. and McClelland, W. C., GSA Special Paper, 541, 1-16, 2018. Schweitzer, H.-J.: Die Devonfloren Spitzbergens (The Devonian flora of Spitsbergen), Palaeontographica Abteilung B Band, 252, Stuttgart, Schweizerbart Science Publishers, 1999. Schwerdtner, W. M., Rivers, T., Tsola, J., Waddington, D. H., Page, S. and Yang, J.: Transtensional origin of multi-order cross-folds in a high-grade gneiss complex, southwestern Greenville Province: formation during post-peak gravitational collapse, Can. J. Earth. Sci., 53, 1511-1538, 2016. Snoke, A. W.: Transition from infrastructure to suprastructure in the northern Ruby Mountains, Nevada, in: Cordilleran Metamorphic Core Complexes, edited by: Crittenden Jr., M. D., Coney, P. J. and Davis, G. H., GSA Memoirs, 153, 287-333, 1980. Steel, R. J. and Worsley, D.: Svalbard's post-Caledonian strata - an atlas of sedimentational patterns and palaeogeographic evolution, in: Petroleum Geology of the North European Margin, Norwegian Petroleum Society (NPF), Graham and Trotman, 109-135, 1984. Steele, T. W. and Stier, J. C.: The Impact of Interdisciplinary Research in the Environmental Sciences: A Forestry Case Study, J. Am. Soc. Inf. Sci., 51, 5, 476-484, 2000. Stemmerik, L., Vigran, J. O. and Piasecki, S.: Dating of late Paleozoic rifting events in the North Atlantic: New biostratigraphic data from the uppermost Devonian and Carboniferous of East Greenland, Geology, 19, 218-221, 1991. Stemmerik, L., Dalhoff, D., Larsen, B. D., Lyck, J., Math- 
iesen, A. and Nilsson, I.: Wandel Sea Basin, eastern North Greenland, Geol. Greenland Bull., 180, 55-62, 1998. Stemmerik, L., Late Palaeozoic evolution of the North Atlantic margin of Pangea, Palaeogeogr., Palaeoclimatol., Palaeoecol., 161, 95-126, 2000. Strachan, R. A.: Evidence in North-East Greenland for Late Silurian-Early Devonian regional extension during the Caledonian orogeny, Geology, 22, 913-916, 1994. Tessensohn, F., Piepjohn, K. and Thiedig, F.: Foreland-Thrust Belt Relation-ships SE of Kongsfjorden and the Function of the Pretender Fault, in: Intra-Continental Fold Belts, edited by: Tessensohn, F., CASE 1: West Spitsbergen, Geologisches Jahrbuch, B 91, Polar Issue No. 7, Hannover, 83-104, 2001. Teyssier, C., Ferré, E. C., Whitney, D. L., Norlander, B., Vanderhaeghe, O. and Parkinson, D.: Flow of partially molten crust and origin of detachments during collapse of the Cordilleran Orogen, in: High-Strain Zones: Structrue and Physical Properties, edited by: Bruhn, D. and Burlini, L., Geol. Soc. London, Spec. Publi., 245, 39-64, 2005. Thiedig, F. and Manby, G.: Origins and deformation of post-Caledonian sediments on Blomstrandhalvøya and Lovénøyane, northwest Spitsbergen, Norsk Geol. Tidsskr., 72, 27-33, 1992. Vogt, T.: The Stratigraphy and Tectonics of the Old Red Formations of Spitsbergen, Abstr. Proc. Geol. Soc. Lond., 1343, 1938. Van Boeckel, M.: Identifying the Controlling Factors on Variable Glacial Modification of Bedrock Dominated Areas in Kongsfjorden, Svalbard, Master's Thesis, UiT The Arctic University of Norway in Tromsø, Troms $\varnothing$, Norway, 103 pp., 2018. Von Gosen, W. and Piepjohn, K.: Polyphase deformation in the eastern Hornsund area, in: Intra-Continental Fold Belts, edited by: Tessensohn, F., CASE 1: West Spitsbergen, Geologisches Jahrbuch, B 91, Polar Issue No. 7, Hannover, 291-312, 2001. Wilson, C. G., Shipley, T., Williams, R. and Tikoff, B.: Does having access to uncertainty information improve geologic interpretation? You tell us!, Geophys. Res. Abstr., EGU General Assembly, May 3rd-8th 2020, Vienna, Austria, 2020. Witt-Nilsson, P., Gee, D. G. and Hellman, F. J.: Tectonostratigraphy of the Caledonian Atomfjella Antiform of northern Ny Friesland, Svalbard, Norsk Geol. Tidsskr., 78, 67-80, 1998. Worsley, D., Agdestein, T., Gjelberg, J. G., Kirkemo, K., Mørk, A., Nilsson, I., Olaussen, S., Steel, R. J. and Stemmerik, L.: The geological evolution of Bjørnøya, Arctic Norway: implica-

Printer-friendly version

Discussion paper
Interactive

comment 
tions for the Barents Shelf, Norsk Geol. Tidsskr., 81, 195-234, 2001. Yin, C., Zhang, B., Han, B.-F., Zhang, J., Wang, Y. and Ai, S.: Structural analysis and deformation characteristics of the Yingba metamorphic core complex, northwestern margin of the North China craton, NE Asia, Journal of Structural Geology, 94, 195-212, 2017. âĂČ Figures

Figure 1: (a) Topographic-bathymetric map around Spitsbergen modified after Jakobsson et al. (2012). Abbreviations: Ad: Adriabukta; Bi: Billefjorden; Bk: Bockfjorden; Bo: Blomstrandhalvøya; Br: Brøggerhalvøya; Fi: Fiskeknatten; Ha: Haitana; Hr: Hornsund; Is: Isfjorden; Kg: Kongsfjorden; Kr: Krosspynten; Ky: Krylen; Mi: Midterhuken; Pk: Påskefjellet; Pr: Pretender Mountain; Ra: Raudfjorden; Re: Reindalspasset; Rø: Røkensåta; Ss: Sassenfjorden; SJ: St-Jonsfjorden; Tp: Tempelfjorden; Tr: Triungen; (b) Geological map modified from svalbardkartet.npolar.no showing the main tectono-stratigraphic units and structures in the study area in central Spitsbergen. Abbreviations: AA: Atomfjella Antiform; Af: Adolfbukta; An: Anservika; BF: Balliolbreen Fault; BL: Bünsow Land;Bn: Bolen; BRF: Blåvatnet Reverse Fault; Fw: Flowerdalen; Gh: Gipshuken; Ki: Kilen; LMT: lower Munidalen thrust; Ly: Lykta; Lø: LøvehovdenHultberget; Mn: Munindalen; Mu: Mumien; Od: Odellfjellet; OF: Odelfjellet Fault; Py: Pyramiden; Re: Reindalspasset; Rö: Reuterskiöldfjellet; Rs: Robertsonbreen; RT: Robertsonbreen thrust; Se: Sentinelfjellet; Sk: Storskarvet; Sæ: Sætherfjellet; TGFZ: Triungen-Grønhorgdalen Fault Zone; To: Torfjellet; Tr: Triungen; Tå: Tåkefjellet; UMT: upper Munidalen thrust; Yg: Yggdrasilkampen.âĂČ

Figure 2: Field photograph showing the pervasive presence of screes and loose material along the boundary between rocks of the Andrée Land Group/Mimerdalen Subgroup and overlying strata of the Wordiekammen Formation, and the poorly preserved and mostly loose outcrops of rocks of the Andrée Land Group/Mimerdalen Subgroup in southern Reuterskiöldfjellet, in Dickson Land. Photo: Jean-Baptiste Koehl. âĂČ

Figure 3: (a) Interpreted and (b) uninterpreted field photograph showing the poor quality of outcrop transects of gently east dipping (tilted?) Lower Devonian rocks of poorly 
deformed red siltstones of the Dicksonfjorden Member and green sandstones of the Austfjorden Member of the Wood Bay Formation (dashed orange lines) unconformably overlain by flat-lying strata of the Wordiekammen Formation (dashed blue lines) in Reuterskiöldfjellet. The presence of abundant grey screes (from the Wordiekammen Formation) and the poorly preserved character of Lower Devonian outcrops (mostly consisting of loose material and bedding surface only possible to identify in a few places) makes it difficult to assess the nature of the unconformity (tectonized or nontectonized?) between Lower Devonian and uppermost Pennsylvanian-lowermost Permian rocks and the nature of the boundary between the Austfjorden and Dicksonfjorden members of the Wood Bay Formation (interpreted as the upper Munindalen thrust by Piepjohn et al., 1997a and Michaelsen, 1998, her figure 53; plain red line). The gently east-dipping and poorly deformed character of Lower Devonian rocks in the area may be the product of Devonian extensional faulting (e.g., tilted along a low-angle late-postCaledonian detachment/normal fault; e.g., Chorowicz, 1992; Friend et al., 1997, their figure 12b; McCann, 2000). View is towards the north. Photo: Reinhard Feisel. âĂČ

Figure 4: (a) Interpreted and (b) uninterpreted field photograph showing the poor quality of outcrop transects of gently dipping (tilted?) Lower-lowermost Upper Devonian rocks of the Wood Bay Formation and Mimerdalen Subgroup (dashed orange lines) unconformably overlain by flat-lying strata of the Wordiekammen Formation (dashed blue lines) in Mimerdalen. The presence of abundant grey screes (from the Wordiekammen Formation) and the poorly preserved character of Lower-lowermost Upper Devonian outcrops (mostly consisting of loose material and bedding surface only possible to identify in a few places) makes it difficult to assess the nature of the unconformity (tectonized or non-tectonized?) almost everywhere in this area. The gently east-dipping and poorly deformed character of Lower-lowermost Upper Devonian rocks in the area may be related to Devonian extensional faulting (e.g., tilted along a low-angle latepost-Caledonian detachment/normal fault; e.g., Chorowicz, 1992; Friend et al., 1997, their figure 12b; McCann, 2000). View is towards the northwest. Photo: Reinhard Feisel. âĂČ

Printer-friendly version

Discussion paper
Interactive comment

\section{Discussion paper}

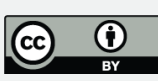


Figure 5: (a) Interpreted and (b) uninterpreted field photograph showing the poor quality of outcrop transects of gently dipping, poorly deformed (sub-horizontal bedding surfaces), Lower-lowermost Upper Devonian rocks of the Wood Bay Formation and Mimerdalen Subgroup (dashed orange lines) unconformably overlain by flat-lying strata of the uppermost Pennsylvanian-lowermost Permian Wordiekammen Formation (dashed blue lines) in Mimerdalen. Note the presence of abundant grey screes from the Wordiekammen Formation masking the unconformity between gently dipping Lowerlowermost Upper Devonian and uppermost Pennsylvanian-lowermost Permian strata. View is towards the west. Photo: Reinhard Feisel. âĂČ

Figure 6: (a) Interpreted and (b) uninterpreted field photograph showing the poor quality of outcrop transects of Lower-lowermost Upper Devonian rocks of the Wood Bay Formation and Mimerdalen Subgroup unconformably overlain by flat-lying strata of the uppermost Pennsylvanian-lowermost Permian Wordiekammen Formation (dashed blue lines) in Reuterskiöldfjellet and Yggdrasilkampen. Note the presence of abundant grey screes from the Wordiekammen Formation masking the unconformity between Lower-lowermost Upper Devonian and uppermost Pennsylvanian-lowermost Permian strata. View is towards the southeast. Photo: Reinhard Feisel. âĂČ

Figure 7: (a) Interpreted and (b) uninterpreted field photograph showing the poor quality of outcrop transects of Lower-lowermost Upper Devonian rocks of the Wood Bay Formation and Mimerdalen Subgroup unconformably overlain by flat-lying strata of the uppermost Pennsylvanian-lowermost Permian Wordiekammen Formation (dashed blue lines) in Sætherfjellet and Reuterskiöldfjellet. Note the presence of abundant grey screes from the Wordiekammen Formation masking the unconformity between Lowerlowermost Upper Devonian and uppermost Pennsylvanian-lowermost Permian strata. View is towards the northeast. Photo: Reinhard Feisel. âĂČ

Figure 8: (a) Interpreted and (b) uninterpreted field photograph showing the poor quality of outcrop transects of Lower-lowermost Upper Devonian rocks of the Wood Bay Formation and Mimerdalen Subgroup unconformably overlain by flat-lying strata of 
the uppermost Pennsylvanian-lowermost Permian Wordiekammen Formation (dashed blue lines) in Munindalen. Note the presence of abundant grey screes from the Wordiekammen Formation masking the unconformity between Lower-lowermost Upper Devonian and uppermost Pennsylvanian-lowermost Permian strata pretty much everywhere in this area. View is towards the north. Photo: Reinhard Feisel. âǍC̆

Interactive

Figure 9: (a) Interpreted and (b) uninterpreted field photograph showing the poor quality of outcrop transects of Lower-lowermost Upper Devonian rocks of the Wood Bay Formation and Mimerdalen Subgroup unconformably overlain by flat-lying strata of the uppermost Pennsylvanian-lowermost Permian Wordiekammen Formation (dashed blue lines) in Storskarvet, Kilen and Sætherfjllet, in Munindalen. Note the presence of abundant grey screes from the Wordiekammen Formation masking the unconformity between Lower-lowermost Upper Devonian and uppermost Pennsylvanian-lowermost Permian strata. View is towards the north. Photo: Reinhard Feisel. âĂČ

Figure 10: (a) Interpreted and (b) uninterpreted field photograph showing the poor quality of outcrop transects of Lower-lowermost Upper Devonian rocks of the Wood Bay Formation and Mimerdalen Subgroup unconformably overlain by flat-lying strata of the uppermost Pennsylvanian-lowermost Permian Wordiekammen Formation (dashed blue lines) in Kilen, in Munindalen. Note the presence of abundant grey screes from the Wordiekammen Formation masking the unconformity between Lower-lowermost Upper Devonian and uppermost Pennsylvanian-lowermost Permian strata. View is towards the north-northwest. Photo: Reinhard Feisel. âĂČ

Figure 11: (a) Interpreted and (b) uninterpreted zoom in the field photograph in Kilen. The outcrop transects of gently east-dipping (tilted?) Lower-lowermost Upper Devonian rocks of the Wood Bay Formation and Mimerdalen Subgroup (dashed orange lines) are mostly made up with loose material and unconformably overlain by flat-lying strata of the uppermost Pennsylvanian-lowermost Permian Wordiekammen Formation (dashed blue lines). Note the presence of abundant grey screes from the Wordiekammen Formation masking the unconformity between Lower-lowermost Upper Devonian

Printer-friendly version

Discussion paper 
and uppermost Pennsylvanian-lowermost Permian strata, making it difficult to study the nature of the unconformity (tectonized or non-tectonized?). The gently east-dipping and poorly deformed character of Lower-lowermost Upper Devonian rocks in the area below the unconformity may be related to Devonian extensional faulting (e.g., tilted along a low-angle late-post-Caledonian detachment; e.g., Chorowicz, 1992; Friend et al., 1997, their figure 12b; McCann, 2000). View is towards the north-north. Photo: Reinhard Feisel. âĂČ

Figure 12: (a) Interpreted and (b) uninterpreted field photograph showing the poor quality of outcrop transects of Lower-lowermost Upper Devonian rocks of the Wood Bay Formation and Mimerdalen Subgroup unconformably overlain by flat-lying strata of the uppermost Pennsylvanian-lowermost Permian Wordiekammen Formation (dashed blue lines) in Kilen and Storskarvet, in Munindalen. Note the presence of abundant grey screes from the Wordiekammen Formation masking the unconformity between Lower-lowermost Upper Devonian and uppermost Pennsylvanian-lowermost Permian strata. View is towards the west. Photo: Reinhard Feisel. âĂČ

Figure 13: (a) Interpreted and (b) uninterpreted field photograph showing the poor quality of outcrop transects of gently east-dipping (tilted?) Lower-lowermost Upper Devonian rocks of the Wood Bay Formation and Mimerdalen Subgroup (dashed orange lines) unconformably overlain by flat-lying strata of the uppermost Pennsylvanianlowermost Permian Wordiekammen Formation (dashed blue lines) in Odinfjellet. Note the presence of abundant grey screes from the Wordiekammen Formation masking the unconformity between Lower-lowermost Upper Devonian and uppermost Pennsylvanian-lowermost Permian strata. The gently east-dipping and poorly deformed character of Lower-lowermost Upper Devonian rocks in the area may be related to Devonian extensional faulting (e.g., tilted along a low-angle late-post-Caledonian detachment; e.g., ; e.g., Chorowicz, 1992; Friend et al., 1997, their figure 12b; McCann, 2000). View is from Munindalen towards the south-southwest. Photo: Reinhard Feisel. âĂ 
Figure 14: (a) Interpreted and (b) uninterpreted field photograph showing the poor quality of outcrop transects of Lower-lowermost Upper Devonian rocks of the Wood Bay Formation and Mimerdalen Subgroup unconformably overlain by flat-lying strata of the uppermost Pennsylvanian-lowermost Permian Wordiekammen Formation (dashed blue lines) in Odinfjellet. Note the presence of abundant grey screes from the Wordiekammen Formation masking the unconformity between Lower-lowermost Upper Devonian and uppermost Pennsylvanian-lowermost Permian strata. View is from Munindalen towards the south-southwest. Photo: Reinhard Feisel. âĂČ

Figure 15: (a) Interpreted and (b) uninterpreted field photograph of the Lykta mountain in Dickson Land (c. five kilometers northwest of Triungen) showing gently dipping (tilted?) Lower Devonian strata of the Wood Bay Formation (dashed orange lines) unconformably overlain by flat-lying strata of the Wordiekammen Formation (dashed blue lines). The gently dipping and poorly deformed character of Lower Devonian rocks in the area may be the product of Devonian extensional faulting (e.g., tilted along a lowangle late-post-Caledonian detachment; e.g., Chorowicz, 1992; Friend et al., 1997, their figure 12b; McCann, 2000). View towards the north. Photo: Erik P. Johannessen. âĂČ

Figure 16: (a) Interpreted and (b) uninterpreted zoom in the top of the Lykta mountain in Dickson Land showing that the unconformity between gently west-dipping (tilted?), poorly deformed Lower Devonian strata of the Wood Bay Formation (dashed orange lines) and flat-lying strata of the Wordiekammen Formation (dashed blue lines) is covered by grey screes from the Wordiekammen Formation and, thus, its nature is not possible to directly observe (undeformed or tectonized unconformity?). View is towards the north. Photo: Erik P. Johannessen. âĂČ

Figure 17: (a) Interpreted and (b) uninterpreted field photograph of the Triungen locality showing southwards-dipping (tilted?) Lower Devonian strata of the Wood Bay Formation (dashed orange lines) unconformably overlain by flat-lying strata of the Billefjorden Group (dashed green lines) and Wordiekammen Formation (dashed blue lines). The

Printer-friendly version

Discussion paper
Interactive

comment 
gently-moderately dipping and poorly deformed character of Lower Devonian rocks in the area may well be the product of Devonian extensional faulting (e.g., tilted along a low-angle late-post-Caledonian detachment/normal fault; e.g., Chorowicz, 1992; Friend et al., 1997, their figure 12b; McCann, 2000). View is towards the east. Photo: Erik P. Johannessen. âĂČ

Figure 18: (a) Interpreted and (b) uninterpreted zoom in southwards-dipping (tilted?) Lower Devonian strata of the Wood Bay Formation (dashed orange lines) unconformably overlain by flat-lying strata of the Billefjorden Group (dashed green line) in Triungen (location shown as a black frame in Figure 17a). View is towards the east. Photo: Erik P. Johannessen. âĂČ

Figure 19: (a) Interpreted and (b) uninterpreted field photograph of the angular stratigraphy unconformity (dotted yellow line) between gently-dipping (tilted?) Lower Devonian strata of the Wood Bay Formation (dashed orange lines) unconformably overlain by flat-lying strata of the Billefjorden Group in Triungen. Photo: Erik P. Johannessen. âĂČ

Figure 20: (a) Interpreted and (b) uninterpreted field photograph showing gently westdipping strata of the Wood Bay Formation (dashed orange lines) overlain by flat-lying strata of the Billefjorden Group (dashed green lines), Hultberget Formation (dashed red line) and Wordiekammen Formation (dashed blue lines), and the probable trace of the Triugen-Grønhorgdalen Fault Zone (TGFZ; plain red line) in Triungen. The photograph shows that the trace of the TGFZ and most outcrops along the fault trace are covered by screes and loose material. View is towards the north-northeast. The gently dipping and poorly deformed character of Lower Devonian rocks in the area may well be the product of Devonian extensional faulting (e.g., tilted along a low-angle late-postCaledonian detachment/normal fault; e.g., Chorowicz, 1992; McCann, 2000). Photo: Erik P. Johannessen. âĂČ

Figure 21: (a) Interpreted and (b) uninterpreted field photograph showing the presence 
of abundant black screes (possibly from coals of the Billefjorden Group) and loose material along the trace of the Triungen-Grønhorgdalen Fault Zone (plain red line) between gently west-dipping strata of the Wood Bay Formation (dashed orange lines) and flat-lying strata of the Billefjorden Group (dashed green lines), Hultberget Formation (dashed red line) and Wordiekammen Formation (dashed blue lines) in Triungen. View is towards the north. Photo: Erik P. Johannessen. âĂČ

Figure 22: Same as Figure 21. View is towards the northwest (Lykta mountain in the background). The gently dipping and poorly deformed character of Lower Devonian rocks in the area may well be the product of Devonian extensional faulting (e.g., tilted along a low-angle late-post-Caledonian detachment; e.g., Chorowicz, 1992; Friend et al., 1997, their figure 12b; McCann, 2000). Photo: Erik P. Johannessen. âĂČ

Figure 23: (a) Interpreted and (b) uninterpreted field photograph showing gently dipping to flat-lying strata of the Wood Bay Formation (dashed orange lines) unconformably overlain by flat-lying strata of the Wordiekammen Formation (dashed blue lines) along the northern flank of Tåkefjellet (c. five kilometers south of Triungen) in Dickson Land. The gently dipping (tilted?) and poorly deformed character of Lower Devonian rocks in the area may well be the product of Devonian extensional faulting (e.g., tilted along a low-angle late-post-Caledonian detachment; e.g., Chorowicz, 1992; Friend et al., 1997, their figure 12b; McCann, 2000). View is towards the southeast. Photo: Erik P. Johannessen. âĂČ

Figure 24: (a) Interpreted and (b) uninterpreted field photograph showing flat-lying to gently southwards-dipping (tilted?) and poorly deformed (sub-horizontal bedding surfaces) strata of the Wood Bay Formation (dashed orange lines) unconformably overlain by strata of the Wordiekammen Formation (dashed blue lines) along the western flank of Tåkefjellet (c. five kilometers southwest of Triungen) in Dickson Land. View is towards the east. Photo: Erik P. Johannessen.

Figure 25: (a) Interpreted and (b) uninterpreted field photograph showing gently south- 
dipping (tilted?) to flat-lying and poorly deformed (sub-horizontal bedding surfaces) Lower Devonian strata of the Wood Bay Formation (dashed orange lines) unconformably overlain by flat-lying strata of the Wordiekammen Formation (dashed blue lines) in Bolen (c. 6-7 kilometers southwest of Triungen), and showing that the unconformity is almost completely covered by grey screes of the Wordiekammen Formation. View is towards the east. Photo: Erik P. Johannessen. âĂČ

Interactive

Figure 26: Database of seismic lines (black lines) in Svalbard. The outline of the Svalbard Archipelago is shown in blue. âĂČ

Figure 27: (a) Interpreted and (b) uninterpreted satellite image from toposvalbard.npolar.no showing probable Eurekan, sinistral, brittle shear fabrics within Cretaceous dolerite in Krylen, in Hinlopenstredet (east of Spitsbergen). This suggests that Eurekan deformation affected pervasively every parts of the Spitsbergen island. âĂČ

Figure 28: (a) Uninterpreted and (b) interpreted NNE-SSW-trending seismic line in Billefjorden showing the presence of kilometer-thick Lower Devonian deposits of the Siktefjellet-Red Bay groups and Wood Bay Formation deposited along WNW-ESEstriking Early Devonian normal faults (red lines; e.g., intra Siktefjellet/Red Bay group and intra-Wood Bay Formation growth strata displayed as dotted white and dashed magenta lines) that were inverted during Eurekan deformation (open anticline above major NNE-dipping normal faults) in the footwall of the Balliolbreen Fault (not visible because parallel to this seismic line). The seismic line also shows varying intensity of Eurekan deformation, which appears to be heterogeneously distributed (e.g., plain yellow lines), and localized particularly within Lower Devonian rocks and along stratigraphic boundaries. White arrows show onlapping, toplapping and downlapping seismic reflections. Location shown in Figure 1 as a yellow line. âĂČ

Figure 29: (a) Uninterpreted and (b) interpreted zoom in Figure 28 showing a top-NNE, Eurekan thrust fault (thick yellow line) flattening into a partial décollement localized along the stratigraphic boundary between Lower Devonian rocks of the Wood Bay For- 
mation and strata of the Wordiekammen Formation (dotted orange). Location shown as a white frame in Figure 28a. âĂČ

Figure 30: (a) Uninterpreted and (b) interpreted outcrop photograph showing poorly deformed sandstone-siltstone-dominated beds within the Lower Devonian Wood Bay Formation just east of Pyramiden. Bedding surfaces are shown as dashed orange lines. Photo: Jean-Baptiste Koehl.

Figure 31: (a) Uninterpreted and (b) interpreted outcrop photograph showing deformed shaly units within the Wood Bay Formation (bedding surfaces are shown as dashed orange lines) affected by cleavage (red lines) and shear surfaces just east of Pyramiden. Note that these beds are located down in the valley, i.e., away from the unconformity with Wordiekammen sedimentary rocks Photo: Jean-Baptiste Koehl.

Figure 32: (a) Interpreted and (b) uninterpreted field photograph showing a Late Devonian, synsedimentary, listric normal fault soling into a coal-seated décollement within the Røedvika Formation (Billefjorden Group), in northeastern Bjørnøya. This shows the capacity of uppermost Devonian-Mississippian coals of the Billefjorden Group to decouple deformation. Black arrows show yellow-colored layers of coal and dashed orange lines represent stratigraphic markers offset by the fault. Photo: Jean-Baptiste Koehl.

Please also note the supplement to this comment:

https://www.solid-earth-discuss.net/se-2019-200/se-2019-200-AC2-supplement.pdf

Interactive comment on Solid Earth Discuss., https://doi.org/10.5194/se-2019-200, 2020. 